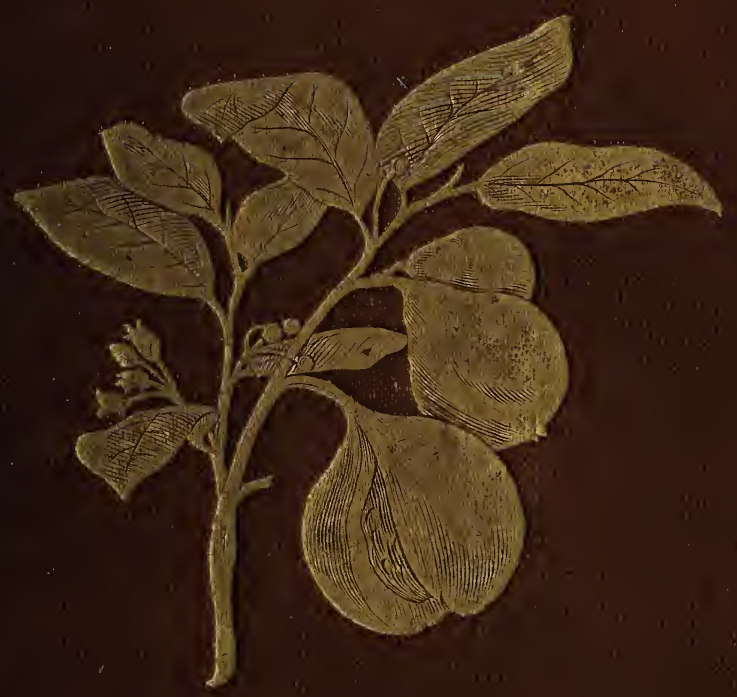


54.

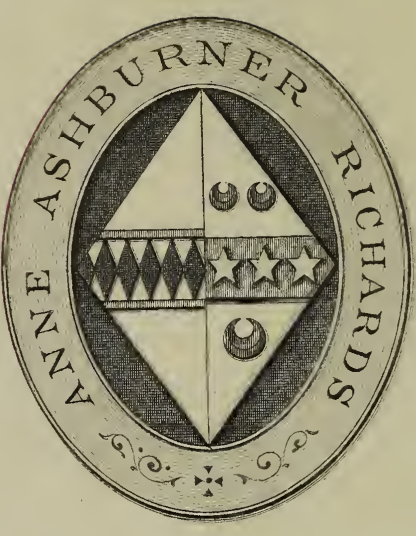


(1) Thehards. 




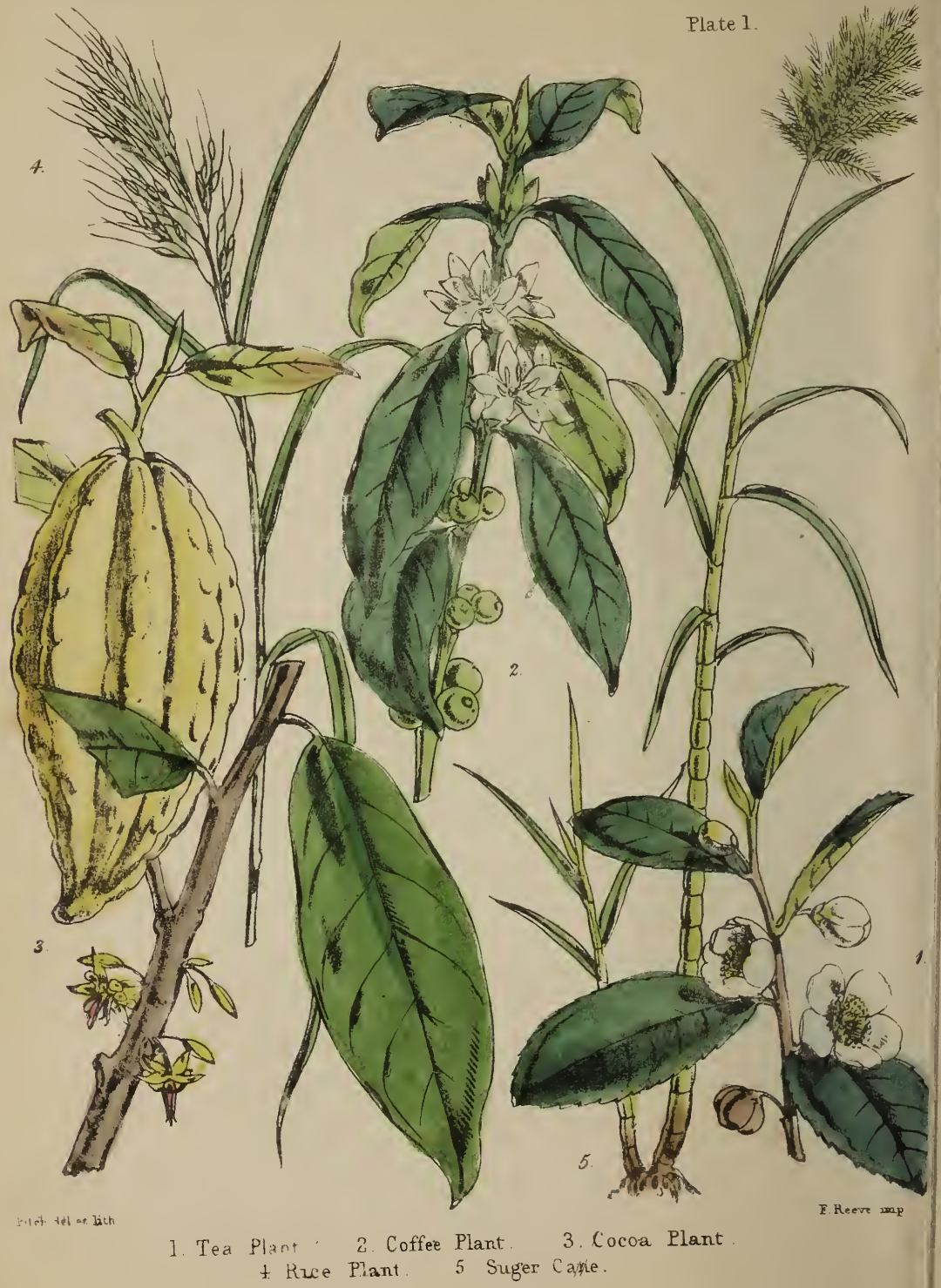




\section{PROFITABLE PLANTS;}

A

DESCRIPTION OF THE PRINCIPAL ARTICLES OF

VEGETABLE ORIGIN USED FOR FOOD, CLOTHING,

TANNING, DYEING, BUILDING, MEDICINE,

PERFUMERY, ETC.

BY

THOMAS CROXEN ARCHER.

WITH TWENTY PAGES OF COLOURED PLATES.

LO N DON :

GEORGE ROUTLEDGE AND SONS, THE BROADWAY, LUDGATE. 



\section{JOSEPH DICKENSON, M.D.,}

PRESIDENT OF THE IITERARY AND PHILOSOPHICAT SOCIETY OF ITVERPOOL,

AND AUTHOR OF THE 'FLORA OF IIVERPOOL;'

$\triangle N D$

\section{BRAITHWAITE POOLE, ESQ.,}

AUTHOR OF 'STATISTICS OF BRITISH COMMERCE,'

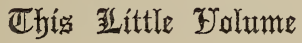

IS WITH SINCERE ESTEEM DEDICATED,

BY THEIR GRATEFUL FRIEND, 



\section{PREFACE.}

IT will appear strange to many when they hear for the first time that no popular work has yet appeared, devoted exclusively to the commercial products of the Vegetable Kingdom; much however has been written, and written well, in various large works, by several authors upon Botany and Matéria Medica, especially by Sir William Hooker, Dr. Royle, Dr. Lindley, and Dr. Pereira, and from their writings much of the information contained in this volume is derived.

I am more particularly indehted to the last-mentioned gentleman. No one has done so much as Dr. Pereira towards dissipating the cloud of ignorance which envelopes the history of vegetable products; and it is much to be regretted that, by his melancholy death, the splendid edition of his large work should have been left unfinished; it is however 
in able hands, and will, doubtless, be completed in a manner worthy of the author.

Vegetable products constitute nine-twelfths of the whole commerce in raw produce which employs the vast mercantile marine of this great kingdom. They furnish us with the bulk of our food and clothing, our medicine and our building materials, and with many other necessaries and luxuries. It may be argued, that most of the benefits we derive from the vegetable kingdom have been discovered without the aid of science. True, but is not this a great and powerful argument in favour of the application of scientific investigation in this department? for if so much has been done without its aid, how much may we not hope will be effected when the principles of scientific research, which have effected such miracles in every other department, are brought to bear upon that of Economic Botany?

Had not a scientific and practical botanist discovered the Gutta Percha, how many benefits would perhaps have been lost to civilization (unless some other article supplied its place in the submarine telegraphs) ; and, latterly, the inves- 
PREFACE.

tigations of botanists have added hundreds of articles to our list of commercial products. What is still in store for us we know not, but we are certain that vast fields for discovery are still untouched, and remain to reward the scientific investigator.

I was preparing to enter very fully into the commercial statistics of the articles described, when the glaring discrepancies which met me in the different works professing to give this kind of information, almost led me to abandon the idea of giving any statistical details. The appearance of a work by my friend Mr. Braithwaite Poole, upon the Statistics of British Commerce, has however led to the removal in a great measure of my difficulties in this particular, and it will be seen that I have availed myself largely of his publication; besides this, I am indebted to him for other useful information, which he has obtained for me through his extensive railway connections.

The classification adopted in the following pages is simple, being a mere division into groups, and the botanical information is slight; they are, however, sufficient to show, 
along with the account of the uses of the articles described, that quality and price do not constitute the only interesting points in their history.

My experience in matters connected with commercial materials has been somewhat extensive: besides twelve years' employment in the Import department of the Customs, which has brought me into contact with most of the articles of foreign produce, I also formed the extensive collection of Liverpool Imports which was exhibited at the Great Industrial Exhibition of 1851, for which I received the Prize Medal and Certificate. Since then I have been acting for the directors of the New Crystal Palace at Sydenham, as their agent for the collection of raw produce; and in these occupations I have obtained some information which I trust may be useful, and obtain for me a lenient judgment for the literary defects of the book.

\section{T. C. A.}

Higher Tranmere, Cheshire, May, 1853. 


\section{IST OF P L A T E .}

Plate I.

Fig.

1 Tea plant

2 Coffee plant

3 Cocoa plant

4. Rice plant

5 Sugar Cane

\section{Plate II.}

6 Maize

7 Buckwheat

8 Long Pepper.....

9 Black Pepper.

10 Clove plant.

\section{Plate III.}

11 Nutmeg plant ......... 95

12 Ginger plant........... 104

13 Cinnamon plant........ 88

14. Allspice plant ......... 100

\section{Plate IV.}

15 Tamarind plant........ 42

16 Olive plant ......... 34, 264
Fig. $\quad$ Page

17 Guava plant ........... 43

18 Great American Cranberry ............... 48

19 Pomegranate ........... 33

Plate V.

20 Litchi .................... 44

21 Prickly Pear ......... 44

22 Fig .................... 26

23 Peccan Nut ........... 64

24. Hickory Nut .......... 64

25 Pistachio Nut ......... 57

Plate VI.

26 Sapucaia Nut.......... 53

27 Brazil Nut ............. 51

28 Surahwa Nut........... 54

29 Cashew Nut .......... 55

30 Almond ................ 67

31 Ground Nut ..... 65, 270

Plate VII.

32 Cotton plant .......... 170 
Fig.

Yage | Fig.

Page

33 Flax plant ............ 148

34. Hemp ................. 151

35 Jute ................... 156

36 Sun Hemp .............. 158

37 China Grass ........... 163

\section{Plate VIII.}

38 Carnauba Palm ........ 281

39 Rattan Palm .......... 167

40 Coquilla Nut Palm ..... 165

41 Manilla Plantain ...... 158

42 The Oil Palm ......... 261

\section{Plate IX.}

43 Sago Palm ............. 81

44. Cocoa-nut Palm 67, 161, 263

45 American Aloe ......... 160

46 Gomuti Palm ..... 140, 164

47 Date Palm

30

Plate $X$.

49 Vegetable Irory Palm 296

50 Vegetable Ivory Nut 296

51 Section of ditto ......... 296

52 Coquilla Nut ........... 297

53 The Nut turned ....... 297

\section{Piate XI.}

53 Arrowroot plant

76

54. Turmeric plant, with starch tubers ......... 77 $54 a$ Section of rhizome ... 77 55 Section of Starch tuber 77 56 Granules of Wheat Starch ................ 73

57 Granules of Potato Starch ................. 73 58 Manihot utilissima 78,79

\section{Plate XII.}

59 Divi Divi .............. 191

60 Valonia .................. 189

61 Camata ................. 189

62 Camatina ............... 189

$63 \mathrm{Pi}-\mathrm{Pi}$.................. 192

\section{Puate XIII.}

64 Persian Yellow-berries 219

65 Turmeric ............... 213

66 White Gall............. 227

67 Blue Gall ............. 227

68 Myrobalan .............. 198

69 Orchella Weed ......... 220

70 Cudbear or Rock Moss 225

\section{Plate XIV.}

71 Safflower plant......... 216 
Fig. $\quad$ Page

72 A cake of Safflower ... 217

73 Indigo plant ............ 229

74. Block of Indigo........ 231

75 Gamboge tree........... 235

\section{Plate XV.}

76 Logwood................. 201

77 Fustic tree ............. 207

78 Munjeet ................ 211

79 Sumach ........... 208, 220

80 Madder ................. 209

\section{Plate XVI.}

81 Cardamom............... 322

82 Castor Oil Seed......... 321

83 Iris or Orrice Root .... 300

84. Patchouly .............. 299

85 Camphor tree............ 314

86 Nux Vomica............ 314

\section{Plate XVII.}

87 Senna shrub ..... 317, 318

88 Peruvian Bark tree ... 318

89 Jalap plant ............. 316
Fig. $\quad$ Page

90 Scammony plant....... 310

91 Liquorice plant ........ 313

Plate XVIII.

92 Gum Benzoin ......... 301

93 Manna ............... 312

94. India Rubber plant... 253

95 Gutta Percha plant... 255

96 Piece of Raw Gutta

Percha ............... 256

\section{Plate XIX.}

97 Turpentine tree ....... 249

98 Canada Balsam tree . 251

99 Piney Tallow tree ... 281

100 Tar and Pitch tree 251, 252

101 Juniper ........... 274, 298

\section{Plate XX.}

102 Mahogany tree ........ 335

103 Lignum Vitæ tree ... 336

104. Cedar tree (Pencil) ... 333

105 Gum tree ............. 340

106 Ebony tree ............ 330 


\section{ERRATA.}

In Plate X., the figures numbered $49,50,51,52,53$, should be numbered $48,49,50,51,52$ : they are referred to by the correct numbers in the descriptive portion of the Work.

In Plate XIX., for Gum Dammar, read Piney Tallow Tree. 


\section{CONTENTS.}

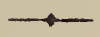

\section{DIVISION I. \\ SUBSTANCES USED FOR FOOD. \\ CHAPTER I.}

FARINACEOUS PRODUCTS

CHAPTER II.

FRUITS

CHAPTER III.

NUTS

CHAPTER IV.

FECULAS OR STARCHES

\section{CHAPTER V.}

SPICES

\section{CHAPTER VI.}




\section{DIVISION II.}

PRODUCTS EMPLOYED IN MANUFACTURES.

\section{CHAPTER VII.}

VEGETABLES USED FOR TEXTILE FABRICS . . . . 147

\section{DIVISION III.}

MISCELLANEOUS PRODUCTS USED IN THE ARTS AND MANUFACTURING PROCESSES.

\section{CHAPTER VIII.}

TANNING MATERIALS . . . . . . . . . 187 CEAPTER IX.

MATERIALS USED IN DYEING. . . . . . . 200 CHAPTER X.

GUMS USED IN THE ARTS . . . . . . . . 239 CHAPTER XI. OILS, OLL-SEEDS, ETC. • . . . . . . . . . . 259 CHAPTER XII. MISCELLANEOUS ARTICLES . . . . . . . . 284 


\section{DIVISION IV.}

MATERIA MEDICA.

CHAPTER XIII.

MISCELLANEOUS MEDICINAL PRODUCTS . . . . 307

\section{DIVISION $\mathrm{V}$.}

CONSTRUCTIVE MATERIALS.

\section{CHAPTER XIV.}

BUILDING AND FURNITURE WOODS . . . . . . . 325 



\section{POPULAR \\ ECONOM IC B T A N. \\ CHAPTER I.}

SUBSTANCES USED FOR FOOD.

\section{FARINACEOUS PRODUCTS.}

WHEN the fiat went forth, "In the sweat of thy face shalt thou eat bread," Almighty Justice pronounced a deserved sentence; but, much as fallen man had offended his Divine Creator, he was not forgotten entirely : labour, it is true, had become his lot, but the fruitful earth was left, as before the fall, clothed with every necessary for man's wants, and requiring only the full exercise of those powers with which his Maker had gifted him, for their development.

The class of substances which come under this chapter are peculiarly of this character: the staple food of more 
than four-fifths of the human race is formed from the small grains of various grasses, which, even if they required no more labour than merely collecting and preparing, would at least enforce industry; but requiring, as they do, careful cultivation in well-worked soil, it is indeed only with the sweat of the brow that we can eat the bread which is necessary to our existence.

Foremost in the rank of food-products, and especially of those called cereals, stands WHEAT, too well known to require any particular description. It is a true grass (belonging to the Natural Order Graminacea), but has been so changed by cultivation that we are totally ignorant of its natural state*. Botanists have named it I'riticum hybernum, or Triticum vulgare, variety $\beta$ hybernum, Winter Wheat,this is the commonest kind of wheat; another, which is almost as well known, is called Triticum vulgare, variety a astivum, or Summer Wheat. The former is biennial in its habits-that is, it is sown one year and flowers and fruits

* Unless the experiments of M. Fabre may be relied upon. He states that he found by successive experiments upon the apparently insignificant grass Egilops ovata, that it first sported (as gardeners call it) R. triticoides, and from that, by successive changes, extending over several years, it passed to wheat itself,-not so fine as our highly cultivated varieties, but nevertheless wheat it was, unmistakeably. 
WHEAT.

the year following; but the latter is sown and perfected all in one year.

Much discussion has arisen amongst scientific men, as to the native country of the wheat; the evidence however appears to be in favour of a district of Russia in Asia, inhabited by the Bashkirs, where it is supposed the wheat-plant has been found growing wild. This district is in the Russian Government of Orenburg, and is inhabited by a warlike race of men, of Turco-Mongolian origin, who are admirable cultivators of various kinds of grain, and are particularly celebrated both for their excellent management of bees, and bravery in defending the Kirghiz steppe for the Emperor. If this Tartar province is indeed the original country of the Triticum vulgare, the culture of which employs millions of our fellow-men, and the produce of which feeds hundreds of millions, it should be to us the most interesting spot on the globe, instead of an almost unknown corner of the Czar's dominions.

Besides the two varieties mentioned, there are several others which are occasionally grown, viz. variety $d, T$. turgidum (a name which signifies swollen), the ear is short and irregularly thick; variety $c, T$. turgidum compositum, this is not only short and thick, but several small secondary ears 
take their rise from the principal ear, giving the appearance of a small bunch of ears. It is the Mummy Wheat, which has latterly excited so much curiosity, in consequence of a statement having been circulated, that it originated from some grains found in the hand of an Egyptian mummy, where it had lain many centuries without germinating, but upon being sown produced plants, from which the seed now termed mummy wheat was raised. This tale is however generally disbelieved; mummy wheat has always been the chief kind cultivated in Egypt and Abyssinia, and much also is grown in Greece; some botanists have thought it a distinct genus, in consequence of the compound structure of its ear, but this character is not found to be permanent. - The other kinds are the Polish Wheat (Triticum Polonicum): though called Polish wheat, it is more extensively cultivated in Northern Africa than elsewhere; Spelt Wheat (Triticum Spelta), and the One-grained Wheat (T. monococcum), the ear of which is small, compressed, and only tworowed, like barley, are not much cultivated. Wheat is imported chiefly for the purpose of being ground into flour for making bread; large quantities are also consumed in the manufacture of fine starch, and as flour in dressing cotton fabrics. It comes to us from almost all parts of the globe : 
the finest of the European kinds is from Dantzic, the grain of which is large, white, and very thin-skinned; besides almost every port in Europe and North America, we receive it from Northern Africa, the East Indies, Australia, and occasionally from the Brazils. The quantity of wheat grown in the United Kingdom is about 144,000,000 bushels, or $18,000,000$ quarters; in addition to this we import nearly $4,000,000$ quarters*. In Great Britain it is estimated that $5,000,000$ acres of land are annually covered with this grain.

The next of the cereals in importance is the $\mathrm{O}_{A T}-$ Avena sativa - the use of which is also very ancient; it is not however mentioned in the Scriptures, although frequently referred to by Grecian and Roman writers; Dioscorides and Pliny both mention it. It is a true grass (Graminacea), and is one of the most beautiful of its tribe: nothing can exceed the graceful elegance of the oat, with its large panicles of flowers hanging from their hair-like pedicels.

Although known to the ancients, there is no reason to believe that this kind of grain was common, for even at an early period of the Christian era the tyrant Caligula is reported to have fed his horses with gilded oats : we can hardly

*Vide Braithwaite Poole's Statistics of British Commerce (Art. Corn). 
imagine the oats mentioned were literally gilded, but must presume the expression applied to the golden colour of the grain.

Many varieties of the oat are cultivated, but the principal ones are the White, and the Black or Tartarian oat; both are annual plants. One called the Potato Oat is a great favourite in Scotland. In the admirable synopsis published by Peter Lawson and Son, the eminent Edinburgh seedsmen, sixty varieties are mentioned. The quantity of oats imported is very inferior to that of wheat : in 1850 we received $1,165,876$ quarters, nearly all of which came from the northern ports of Europe; but the quantity cultivated in Great Britain far exceeds that of all other cereal grains added together; the total quantity given for England, Ireland, and Scotland, in Poole's Statistics, being 30,500,000 quarters, or $244,000,000$ bushels.

In the northern parts of the kingdom the oat forms the staple article of human food; but its greatest use is in feeding horses. When the bran, or outer integument of the grains, is removed, they are called "Groats," or when skinned and partially crushed, "Embden Groats," which are much used in making the light and easily digested invalid diet called gruel. 
Barley. Hordeum distichon. (Nat. Ord. Graminacea.) Another grass, the seeds of which are of immense importance to man; besides this, the common species, there are three others more or less cultivated. Barley has long figured as an economic product of the Vegetable Kingdom. Arnongst the Egyptians it was well known, and its discovery and first culture was by Diodorus Siculus and others attributed to Osiris. Pliny, in his 'Natural History,' says barley was the most ancient food of mankind. In the Book of Exodus, dating fifteen hundred years before Christ, we find it mentioned as an ordinary crop, thus, in ch. ix., verse 31, "And the flax and the barley was smitten: for the barley was in the ear, and the flax was bolled;" and we find it again mentioned in Ruth ii. 17, "She gleaned in the field until even, and beat out that she had gleaned, and it was about an ephah of barley." Its native country is unknown, but by some authors is supposed to he Tartary. The common names of the four species are Long-eared or Common Barley (H. distichon), Spring Barley (H. vulgare), Winter Barley (H. hexastichon), and Sprat or Battledore Barley ( $H$. zeocriton). The Spring barley is in Scotland usually styled Bere or Bigg; it is an inferior kind, but valuable from its thriving on poor soil and in exposed localities. 
Barley is not so much used for food now as formerly. Barley-bread, once the common food of the poorer classes, is rarely seen in this country; its great use is in making beer and spirits. For beer it is first malted, (a process which consists in inducing germination in the grain,) by soaking it in water and applying heat; this causes the barley to shoot, and as soon as vitality is once commenced, the starch which existed abundantly in the grain is converted into sugar, which, if fermented, is easily convertible into the half-vinous beer, or, by a little increased fermentation, into alcohol. The quantity grown in the United Kingdom is very large, amounting to nearly 10,000,000 quarters; but the imports are comparatively small, being only 51,000 quarters in 1851, all from the north of Europe.

RYe. Secale cereale. (Nat. Ord. Graminacea.)

A native of the Caucaso-Caspian Desert. It is much cultivated in the North of Europe, where it enters largely into the food of the inhabitants; it is highly nutritive, but nevertheless is not much used in this country, where a prejudice exists against it, arising very probably from the serious and fatal accidents which have been occasioned by the vegetable poison called Ergot of Rye. The ergot is a fungous plant which affects the grain, considerably altering its di- 

mensions and appearance; the diseased grain being usually about an inch in length and of a jet-black colour. When mixed with the rye in large quantities-which happens some seasons-its effects are very dreadful, giving rise to ulceration and mortification of the extremities. These injurious effects could hardly happen now that the means of cleaning grain and the methods of cultivating it are so much improved; nevertheless it is far less cultivated than its otherwise wholesome qualities would seem to demand. The quantity imported into the United Kingdom in 1849 was 241,613 quarters, and in 1850 94,078 quarters. (Poole's Statistics.)

Indian Corn-Maize. Zea Mays. (Nat. Ord. Graminacea.) (Plate II. fig. 6.)

A native of Tropical America. Within the last century this grain has become of immense importance to the human family, furnishing, in countries adapted to its cultivation, enormous quantities of a wholesome and nutritive diet. Its culture has spread over the whole of the American continent, throughout most parts of Asia and Africa, and the southern parts of Europe; it is remarkably prolific, and is cultivated with less labour probably than any other grain. Its culture has led to the production of numerous varieties, amongst 
which the most conspicuous are the Large White, the Large Yellow, and the Red American sorts, and the Small Yellow of Southern Europe.

Owing to its deficiency in gluten, maize is not well adapted for making bread; it is however made into cakes, which are much esteemed in North America. Throughout the whole of the American continent and islands it enters largely into the common food of the people, in a great variety of ways. Like oats, it is reduced to meal, the pericarp or bran remaining mixed with the flour. In the preparation called homminy, the grain is first soaked, and then exposed to a drying heat, which causes the bran to crack and peel off, it is then easily separated: in this state it is much used for puddings and other dishes. Pop-corn is another preparation, made by slightly baking the unripe grains, which makes them turn inside out, giving them the appearance of tapioca: this is also a favourite method of using the corn.

Several attempts have been made, but without success, to cultivate maize in England: our summer is too short, and our autumn too humid; it is however extensively imported from the United States and Italy, and used for feeding cattle, etc., but is not regarded with much favour as human food. The imports in 1847 (the year in which the potato- 
crop failed) were $3,614,637$ quarters ; in 1850, 1,286,263 quarters*. The maize belongs to the Class Monocia and Order Triandria of Linnæus, because, like a few others of the Graminacece, it has its stamens and pistils in different flowers on the same plant; the staminiferous flowers are borne in a tuft on the summit of the plant, the pistilliferous ones rise from the axils of the leaves, which, as in most grasses, are sessile along an unbranched stem. The perianth, or floral envelope, of the pistil flower, remains until the grain ripens, and in the South of Europe is very extensively used in packing oranges and lemons; it is also used in South America by the Spaniards in making cigarrettos, for which purpose the very thin Indian corn covers are solected, and small squares are cut from them, in which the tobacco is rolled. These perianths have also been manufactured into very good paper.

Rice. Oryza sativa. (Nat. Ord. Graminacea.) (Plate I. fig. 4.)

This useful grain is a native of the East Indies, whence it has spread to all the warm parts of Asia, Africa, and the southern parts of America; its habit of growth is very much like the oat, the grain hanging gracefully from the very *Poole's Statistics. 
thin hair-like pedicels of an elegant loose panicle, less however than that of the Oat. Although several ill effects, and even cholera* itself, have been attributed to the use of this food, nevertheless these accusations are not well-founded, for, on the contrary, rice appears from its astringency to be admirably adapted to the use of the natives of warm climates, where it usually constitutes the staple food of the lower classes. Its antiquity is very great: "Cast thy bread upon the waters, and it shall return to thee after many days," evidently applies to rice, which, in Egypt, is always sown whilst the waters of the Nile still cover the surface of the land; the returning floods leave a thick deposit of rich alluvial silt, in which the rice vegetates luxuriantly, being naturally a marsh plant. The rice from the Southern States of North America is decidedly the best, being much siveeter, larger, and better-coloured than that of Asia, where its cultivation is less carefully managed. The States of Carolina produce the best American, and Patna the best East Indian rice.

Like wheat and other grain; the rice is that particular

* In the 'Lancet,' 1833-4, vol. i., Dr. Tytler attributes malignant cholera to the use of rice as food, in consequence of which he named the disease morbus oryzeus. 
form of fruit which is called a caryopsis: its characters are that the pericarp or seed-covering appears to cover the seed so closely as to form a portion of it: thus the seed-vessel of the wheat is the brown covering which constitutes the bran, and cannot be removed without breaking the enclosed white seed; in the rice however the pericarp is not so closely adherent, and can be removed by slight pressure, which causes it to split and come off without injuring the enclosed seed. It often comes to us in the husk, and is then called paddy, an Indian name. In this country immense quantities are consumed, but rather as a luxury, in the form of puddings and confectionery, than as a principal article of food. In India a species of arrack, or strong spirit, is distilled from paddy. The straw has lately been much used in plaiting for ladies' bonnets. The beautiful Chinese manufacture called rice-paper is erroneously supposed to be manufactured from this grain : its proper history will appear in another chapter.

The quantity of rice imported into Great Britain in 1851, according to Poole's Statistics, was 41,121 tons ; but of this enormous quantity a large proportion is again exported to our North American colonies and to the countries of Northern Europe. 
Guinea Cons, Darra, Durra, or Turkish Millet, called in India Joar.-The seed of Andropogon Sorghum. (Nat. Ord. Graminacea.)

A roundish grain, in shape not unlike the maize, but not of greater bulk than a small grain of wheat; its colour is a yellowish-white, in some varieties marked with a black spot. It is borne in loose tufts or panicles, several grains being attached to each of the upright pedicels at short distances from each other; the stalks are about eighteen inches to two feet in height, and when dry are very rigid,-in this state they are much used in the manufacture of carpet-brooms and whisks. The grain itself is chiefly used in this country for feeding poultry; it is however strongly suspected that wheaten flour is not unfrequently adulterated with it when it is in the market, but this can only occasionally take place, as the importation of Durra is very irregular. It is much used as food for the black population in the West Indies, whence it has been called negro corn: they make of it cakes about an inch thick, which are white, and tolerably palatable. It is also used by the poorer peasants of Italy. All kinds of poultry, pigs, cattle, and even horses eat it with avidity. The quantity imported is very uncertain, some years passing without any arrivals of Durra, while at other 
times many hundreds of quarters arrive. It comes chiefly from Northern Africa; it is however cultivated largely in the United States, West and East Indies, and in Southern Europe. It is a native of India.

MiLlet.-There are several distinct species of grain commercially known by this name; they all belong to the same Natural Order (Graminacea).

1. The Italian Millet-Setaria Italica-is a small round grain, much like mustard-seed, but rather more than half its size; it is sweet and wholesome; its use in this country is almost wholly confined to confectionery. It is cultivated and used extensively in India, under the name of Koongoonie, Kala-kangnee, and Kora-kang. It is grown chiefly in the neighbourhood of Calcutta.

2. German Millet-Setaria Germanica-which is very little used, except for feeding cage-birds.

3. Millet Proper-Panicum miliaceum-is a native of the East Indies, where it is extensively cultivated, under the names of Warree and Kadi-kane. The principal districts in which it is grown are Madura, Palamcottah, and Tinnevelly.

Several other species are used for food in various parts of the world, but those mentioned are the only ones which are brought to this country, and of them only very small quan- 
tities are imported, the arrivals of which are very irregular and uncertain.

Canary Seed. Phalaris Canariensis. (Nat. Ord. Graminacece)

Though not used for human food, this seed is very extensively used in this country in feeding cage-birds, for which purpose it is both grown and imported. Many acres are annually cultivated with this crop in Kent, and we sometimes receive several hundred quarters from Germany, where its culture receives considerable attention. The Isle of Thanet is the chief place of its culture in England, and here its straw when cut into chaff is highly valued as fodder for horses.

Buckwheat. Fagopyrum esculentum. (Nat. Ord. Polygonacece) (Plate II. fig. 7.)

Probably a native of England; it is much cutivated in Northern Europe and in North America, where, in the form of buckwheat cakes, it is a favourite food. It comes occasionally to this country from Germany, chiefly for use as seed. It forms excellent food for pheasants, and for that purpose is sown extensively in the vicinity of game-preserves. The seed is about twice the size of mustard-seed, rather longer than broad, and having three sharp angles running 
PEAS. BEANS.

longitudinally; the colour is a dark brown; it is deprived of its husk in a manner similar to that employed with rice, and the kernel is then ground to a coarse meal. Small quantities of this meal occasionally reach us from the United States, but chiefly as presents; there is no regular commercial demand.

Peas, or Pease (both names are commonly used, com. mercially). Pisum sativum. (Nat. Ord. Leguminosa.)

This is the common white garden-pea in a ripened state. We annually receive large quantities from Dantzic and other northern ports, which are used as food for man and various domestic animals. The quantity of peas imported into the United Kingdom in 1850 was 181,419 quarters, and about four times that quantity was home-grown.

Beans. Faba vulgaris. (Nat. Ord. Leguminosa.)

The only kind of bean imported in any considerable quantities is the Egyptian or common horse-bean, which is largely consumed for feeding horses. The same species is extensively cultivated in this country, but the consumption is so great, that not less than 443,306 quarters were imported in 1850. Previous to 1845 the average imports of five years was 161,418 quarters, whilst in the succeding five years it increased to 415,655 quarters; the greatest quan- 
tity was in 1848 , when not less than 480,706 quarters were received from Alexandria and Cairo.

Beans (American Haricot)-Phaseolus vulgaris.-There are several varieties of this bean, differing only in colour; the white is most used, and during the scarcity which resulted from the failure of the potato-crop in 1847 and 1848, about 1200 quarters were sent to England from the United States. These beans were usually boiled and eaten as a vegetable with animal food; by many persons they were much liked, but were not generally considered easy of digestion. They are the same species as the French bean of the gardens, and the French Haricot, but are an inferior variety.

TARes, or Vetches. Vicia sativa. (Nat. Ord. Leguminosa.)

The tare is a common crop in our own fields, and, being cut when the plant is green as fodder for cattle, the ripened seeds are only used for the purpose of sowing, and are usually raised by our farmers and seedsmen; a few hundred quarters are however annually imported from Norway and Denmark and the North of Germany.

Lentils. Ervum Lens. (Nat. Ord. Leguminosa.)

The large lentil, which we receive from France, and usually 
imported by the "Italian warehousemen" is sold by them for making soup similar to that made from peas. The article so much advertised as food for infants and invalids under the name of "Revalenta Arabica" is the farina of the lentil freed from the outer skin, which is considered unwholesome.

The small Egyptian Lentil (Ervum Lenticula), originally a native of Carinthia, is occasionally imported in considerable quantities : it is chiefly used in feeding cattle. It is of a red colour, and scarcely half the size of the French lentil. As none of the genus Ervum are natives of Asia, it is most probable that the lentils mentioned in Holy Writ were the White Lupins (Lupinus albus: Leguminosa), which are not only natives of Asia, but are now extensively cultivated in many parts of Asia and Southern Europe for the purposes of food. These white lupins are occasionally imported into England in small quantities, chiefly for the use of the resident Italians, who are fond of this kind of pulse.

Ceci, Cicer, or Chick-Pea. Cicer arietinum. (Nat. Ord. Leguminosa.)

This pulse somewhat resembles the white pea, but is rather larger and more irregularly shaped. It is much used in Fastern countries, as a nutritious food, under the name of Gram. When roasted, it is said to sustain life longer than 
any other food in small quantities; hence it is much used by travellers over the deserts, where the carriage of bulky food is inconvenient. It is imported occasionally, but for what purpose is not very clear,-it is thought for the purpose of roasting and grinding up with coffee as an adulteration.

This probably is the best place to mention a few seeds which are imported in considerable quantities, wholly for agricultural purposes, either because they are better ripened abroad, or because the supply of home-raised seed is insuffcient to meet the demand.

Lucerne Seed-Medicago sativa (Leguminosa).-A small reddish-yellow seed, not quite so long, but thicker than a carraway seed, and the skin is quite smooth. It is a native of Britain, but is often imported from Holland and France.

Clover (Dutch)-Trifolium repens (Leguminosa).-This seed is extensively imported from Holland and Germany. Although a native of most parts of Europe, it ripens best in those countries, and the imported seed is much esteemed. It is a minute kidney-shaped seed, less than half the size of a mustard-seed, and of a yellow or brown colour.

Clover (American)-Trifolium Pennsylvanicum.-Of this species we receive very large quantities. It is found particularly well adapted for culture in this country, and the 
imports have reached nearly 400 tons annually. As its name imports, it is a native of Pennsylvania, in the United States. In form it resembles the Dutch Clover, but its colour is a reddish-yellow.

Timothy Seed, or Timothy-grass Seed-Phleum pratense (Graminacea).-A beautifully small and silky little grassseed, which is sent in rather large quantities from North America. This and the following are the only kinds of grass-seed imported in quantities of commercial importance.

Italian Rye-grass Seed-Lolium Italicum (Graminacea). -A large coarse kind of grass-seed, the produce of which is much esteemed for its rapid growth and bulk. From five to six hundred bags and bales are annually imported from the Levant. 


\section{CHAPTER II.}

FRUITS.

Those vegetable products which we shall describe in this chapter naturally divide themselves into two sections- "The Fleshy Fruits" and "The Nuts." They are numerous and very interesting; coming as they do from almost all parts of the globe, they give us much information respecting the aspect of the Vegetable Kingdom in the distant regions from whence they are brought. Some are rare, and do not often meet the eye of even those who are curious in such things; others arrive in such enormous quantities as to furnish employment for an immense amount of tonnage in shipping, and many hundreds of thousands of persons, constituting an important source of revenue, and giving us an abundance of particularly useful and wholesome food. 
THE GRAPE.

The Fleshy Fruits.-The most important of these in every respect is

The Grape. Vitis vinifera. (Nat. Ord. Vitacea.)

With the exception of the "forbidden fruit" of the "tree of knowledge," the grape is the first fruit mentioned in the history of the world, for we find it stated in Genesis ix. that "Noah began to be a husbandman, and he planted a vineyard: and he drank of the wine." This was at least four thousand years from the present time; we may therefore safely conclude that the vine is a native of Asia, whence it has followed the tide of civilization into Europe and Africa. It is now luxuriating in the genial climates of North America and Australia, where it bids fair to be of immense importance.

Since the time of Noah, history furnishes us with a continuous series of facts, proving that this fruit has been con. stantly cultivated for the wine made from its juice. It has furnished an endless theme for poets and for prose-writers, and from its noble qualities has supplied both prophets and bards with striking similes and metaphors. Even the Redeemer, who despised nought that the Father had created, said, "I am the vine, and ye are its branches ;" and his own blessed blood he likened to the juice of the grape. 
Of wine, the manufactured juice of the grape, we could say much that would be interesting, but it does not belong to a history of raw materials; we may however state, as a proof of its importance, that the quantity imported into the United Kingdom in 1850 was not less than 7,970,067 gallons, of which only 1,691,702 gallons were re-exported. We receive comparatively few grapes in a fresh state: about three hundred tons arrive every autumn from Sicily, Lisbon, and Hamburg; the latter, the produce of Germany, are finely coloured round black grapes; the former, from Sicily and Portugal, are oval berries, in large bunches, and both black and white. They suffer much in flavour from being closely packed, and still more from the use of sawdust as a packing material.

Raisins, or Dried Grapes (Uva passe majores), by far the most important form in which this fruit is received, are of various kinds, according to the variety of grape from which they are prepared, or the mode of their preparation; thus, some varieties are stoneless, presenting the curious anomaly of a true fruit being perfected without seed, a peculiarity which occasionally takes place in highly cultivated plants: this, although in the first instance only an accidental variety, yet is capable of being propagated and 
rendered permanent. The Sultana raisin, which we receive from Smyrna, is of this kind; the black raisin of Smyrna is quite the reverse, for it has remarkably large seeds and poor berries, besides being of a black, instead of a very light reddishbrown, colour. Other raisins are distinguished by the mode in which they have been preserved; thus, the finest are dried on the vines, and when ripe the stalk of the cluster is partly cut through, and the leaves removed from near it, by which means the drying is facilitated, and the fruit acquires a fine bloom : these Muscatels, or Raisins of the Sun, are the finest quality. The commoner kinds are gathered when fully ripe; they are then hung on lines, or laid on floors to dry, and then dipped into a lye of wood-ashes and barilla, of about $1 \cdot 110$ specific gravity, to every four gallons of which is added a handful of salt and a pint of oil. The effect of this immersion is to make the saccharine secretions exude to the surface, giving the fruit the peculiar brown varnished appearance which distinguishes the ordinary raisins from those used for the table. The kinds usually imported, besides those mentioned, are Valencias, Lexias, and Denias, from Spain; Malagas from Malaga; and Red Smyrnas from Turkey. The average annual quantity imported during the last five years has been about 12,000 tons. 
Currants.-A curious variety of the grape, which, besides its extreme smallness, is also deficient in seeds or stones. Originally Corinth was the principal place of its culture,whence the name Currants, or, as they were formerly called, Corinths. Enormous quantities are cultivated in the Greek Islands of Patras, Corfu, Licata, Zante, Ithaca, etc., which are dried and trod into large casks, and exported. The imports of Great Britain exceed 21,000 tons annually. This fruit is largely consumed in confectionery and culinary preparations, by all classes of people, and is very much esteemed.

Tне Fig. Ficus Carica. (Nat. Ord. Urticacea.) (Plate V. fig. 22.)

The fig is a peculiar form of fruit, differing materially from most others in its botanical characters : it is, in fact, nothing more than an inverted fleshy receptacle. It may be explained thus : examine the sunflower, and it will be found that the large head (capitulum) or flower, as it is commonly termed, consists of a great number of small florets, placed close to each other, upon the surface of a flat disc or receptacle; now we have only to imagine this receptacle turned up at the edges until they meet all round, the florets would then be enclosed, and we should have a fruit similar to the fig. After the internal florets of the fig have performed their 
THE FIG.

functions, the receptacle increases in bulk, and buries all the carpels, with their seed, in its sweet pulpy flesh : this constitutes our fig. The pulp is highly saccharine, containing not less (in fine Smyrna figs) than 62 per cent. of a particular variety of sugar called Sugar of Figs. There is sometimes a failure in the fig-crop, when it is not properly attended to, in consequence of the pistils of the florets not becoming fertilized by the pollen of the stamens. It is supposed that this operation is caused naturally by the entry of insects through the very small orifice which remains open in the flowering fig; the fig-growers therefore adopt artificial means to ensure the fertilization-a small feather is inserted and turned round in the internal cavity: this operation is called caprification. They are either dried in the sun, or in ovens built for that purpose. Those which are called "pulled figs" are the best. Two principal kinds of pulled figs come from Smyrna, whence we receive most of the Turkey figs; the better of the two is called "Eleme," or "Elemi," and the other "selected."

The fig-tree grows to a considerable size, and affords a grateful shade in those parts of Asia where it is cultivated. It is the first tree mentioned by name in Holy Writ, its broad and handsome leaves having furnished the first clothing for 
our race. It has always been esteemed for a variety of valuable qualities. In Isaiah xxxviii. 21 we find it used by Hezekiah as a remedy for boils; and even now, 2400 years after that time, we find a roasted fig often used for that and similar purposes.

Many important trees are closely allied to the fig, as, for instance, the Bread-fruit, the deadly Upas-tree, our common Mulberry, and the India-rubber; besides smaller plants, as the hop, hemp, nettle, etc. The natural family has however been divided, by Lindley and others, with great reason, into four or five distinct and well-defined orders.

The quantity of figs consumed in this country is immense; nearly 700 tons were imported in 1851. Those from Greece are usually in barrels or baskets, very much dried, and threaded in strings upon a long rush. The figs of Turkey are more carefully packed, in small cylindrical boxes called drums, and occasionally in small square boxes. A few bay-leaves are usually put upon the top of each box, to keep the fruit from the ravages of a grub which is very destructive to them.

A kind of preparation called fig-cake is occasionally imported; it consists of figs and almonds worked up into a paste and pressed quite hard into cakes of a round form, 
PRUNES.

somewhat like small cheeses. It is usually sold about the streets, but is very little esteemed.

Prunes. Prunus domestica, variety $\zeta$ Juliana. (Drupacece, Lindley.)

This fruit is the Julian variety of the common plum, dried either by spreading them on hurdles exposed to the sun, or on the floors of brick ovens; the former method is however 'generally used, except in unfavourable seasons. We receive them in large quantities from France, the imports in 1850 being nearly 300 tons. They are very much used in the manufacturing districts, where they are a favourite kind of fruit for pies and puddings; they are also used medicinally, in consequence of possessing slight laxative qualities.

The French Plum, or Table Prune, is a much finer variety of plum-Prunus domestica, variety $\eta$ Catharinea, and probably other varieties. They are much larger and contain more sugar. They are usually packed in very elegant boxes, called cartoons. They are carefully dried in the sun, and packed one by one, whereas the common prunes are thrown and pressed into barrels. They usually fetch a high price, and are only used as a table-fruit. About 90 tons were imported in 1851 . 
Dates. - The fruit of the Date Palm, Phonix dactylifera. (Nat. Ord. Palmacere.) (Plate IX. fig. 47.)

This is one of those vegetable products which are of far greater importance in the countries where they are produced than in our own. The date is not a favourite fruit in England, although it is difficult to explain the reason why, for it has many excellencies: to many, the flavour is very agreeable, and very few fruits possess such highly nutritive qualities. Dates come to us from Barbary and Egypt, and are usually of the variety termed Tafilat; we however occasionally receive a few from Egypt of the variety called White Dates, which are smaller, being not much larger than an acorn, and nearly as smooth. The colour is a dull yellowish-white; the former variety is of a dark reddish-brown colour, more than twice as large as the white one; itsw surface is wrinkled and covered with a moist saccharine exudation.

Dr. James Richardson, in writing upon the dates of Fezzan, says, "When every other species of food fails, the date-palm yields, with the returning year, its nourishing and powerful fruit, and saves the population of the desert from perishing of hunger. Nineteen-twentieths of the population of Fezzan live on dates during nine months of the 
year. Many of the animals likewise feed on dates the greater part of the year, the oases being bare of herbage." Dr. James Richardson describes, in the letter above quoted*, no less than forty-six varieties of this fruit which he found cultivated in the oases of the deserts of Northern Africa. The first question of the Bedouin is, "What is the price of dates at Mecca or Medina?"

The date-palm belongs to the Linnæan Order Dicecia, i.e. the stamen-flowers and pistil-flowers are on different plants, consequently they require the intervention of insects, or some other means, for the conveyance of the pollen from the stamens to the pistils : this is usually done by bees, but occasionally this source of assistance fails, and the trees remain barren. Relative to this fact, Michaux records an interesting indication of the careful forethought of the Persians, who, being at war at the time, and knowing the facilities their enemies had for destroying the pistil-bearing palms, they saved a quantity of pollen in hermetically sealed tubes, with which they fertilized the pistilliferous flowers. After the destroyers had passed on, their perseverance was rewarded with as plentiful a crop of this essential food as if it had been produced in the usual manner.

* Hooker's Journal of Botany, vol, ii. 
The date-palm is a magnificent plant, throwing up its stem to the height of fifty feet and upwards. From the summit of this stem the leaves spread out in the most elegant tuft; they are pinnated, or have a row of pointed leaflets on each side of the immense leaf-stalk, which is often as much as five feet in length. The graceful elegance of the Eastern groves of palrn-trees cannot be better described than in the exquisite language of the poet Moore-

"Those groups of lovely date-trees, bending Languidly their leaf-crown'd heads, Like youthful maids, when sleep descending Warns them to their silken beds."

The flowers are at first enclosed in a floral envelope called a spathe, or perianth. They push out from between the leaves, and, when fully developed, form large branched bunches, upon which the fruit is borne; the fresh fruit, if fully ripe, is called ruteb. In this state it will not keep long: in order to be able to transport the fruit to distant countries, it must be gathered when not quite ripe, and dried in the sun. Besides the fruit, the heart of the tuft of leaves, usually called the Palm-cabbage, is much esteemed as a vegetable; but the tree dies when this is cut off. From the wound thus made by the removal of the cabbage, an 
THE POMEGRANATE.

immense quantity of liquid flows, which speedily ferments, and, upon being distilled, yields an inferior variety of Arrack. The wood of the date-palm will be described in its proper place.

Whenever the palm is mentioned in Scripture, the datepalm is always intended. Its cultivation has, from the earliest commencement of the historic period, been an object of importance in Northern Africa and various parts of Asia. Burckhardt, in his Travels in Arabia, speaks of the datepalm as forming the chief wealth of the inhabitants. The trees are hereditary, and sold as estates; and the wedding portion of a bride is often in date-trees. The quantity of dates imported into England is small, seldom exceeding ten or twelve tons per annum.

Pomegranate.-The fruit of Punica Granatum. (Nat. Ord. Myrtacea.) (Plate IV. fig. 19.)

A shrub, forming extensive woods in Persia, and much cultivated in the warmer parts of Europe. The fruit is about the size of a large poppy-head, and not unlike it in shape; the rind is leathery, or more like a corky bark, but when ripe and fresh it is beautifully coloured of a golden yellow, with a rosy tinge on one side; when opened, it contains a number of carpels, having the appearance of red 
currants packed very close and without any apparent arrangement; upon closer examination they are however found to be arranged in two tiers, with pithy partitions running between them.

In the early ages of the world the pomegranate was very highly esteemed, and in hot countries its sub-acid juice is perhaps more grateful to the palate than even that of grapes. It is stated to be a native of Carthage, but this rests solely upon the evidence of Pliny, who had but very limited means of determining such a point. It is now cultivated in Italy, Spain, Portugal, and Southern France; it will even bear the winters of England, and flowers, but does not fruit with us. We annually receive a few chests of pomegranates from Portugal, and sometimes, though rarely, from Barbary. The rind is used in tanning the celebrated Morocco leather. The flowers are very beautiful, of a rich crimson colour; they are dried in Barbary, and are used in dyeing and in medicine by the Moorish inhabitants.

Ourves.-The fruit of Olea Europaa. (Nat. Ord. Oleacea.) (Plate IV. fig. 16.)

This fruit is only brought to Britain in a preserved state, being gathered unripe and pickled in a solution of salt. It is used as a dessert fruit, rather for the purpose of renovating 
THE SWEET ORANGE.

the palate than for its flavour, which in its pickled state is often disliked. The olive is a long oval berry, very much like a common acorn, both in colour and shape. It consists of a one-seeded nut, enclosed in a dark bluish-green fleshy drupe, which, for pickling, is gathered while green. The nut is extremely hard, and was originally a two-celled carpel, but one seed only being developed, the superfluous cell is absorbed. When ripe, the fleshy covering is found to contain oil in great abundance. (See Olive Oil.) There are varieties found in commerce, the only difference of which probably is climatal; they are the large, or Spanish, and the small, or French.

The olive is a fine large tree, of slow growth, and attaining an immense age. It is first mentioned in Genesis viii. 11: "And the dove came in to him in the evening, and lo, in her mouth was an olive leaf plucked off." Very few trees exceed the olive in graceful beauty; it has elegantly coloured leaves, similar in shape and size to those of the willow, but softer and more delicate. It will survive our coldest winters, but does not perfect its fruit in this country; besides which, the tree loses much of its beauty in our climate. About 11,000 or 12,000 gallons are annually imported, some of which are again exported to the colonies and other countries. 
The Sweer Orange. Citrus Aurantium. (Nat. Ord. Aurantiacece)

This valuable and interesting fruit is comparatively a recent introduction to Europe : the Bitter Orange, Lemon, and Citron have been much longer known. Much doubt exists as to the native country of the orange, but China and the north of India appear the most probable native habitats. Orange-trees have now found their way into every country of which the climate is suitable to their culture. Southern Europe seems to be particularly adapted to the orange. As might naturally be inferred from its adaptability to so great a variety of soil and climate, it sports into a vast number of varieties. Like the apple, it has been brought to perfection from a state even worse than the crab, and passes into new varieties whenever great care is bestowed in rajsing new plants; it is not however so manageable in the hands of the horticulturist as many other fruits, from the greater tendency which seedling plants have to revert to the wild state.

The orange is now found in China, India, North and South Africa, Southern Europe, Turkey, the islands of the Mediterranean, South America, and the Azores and West Indies. So thoroughly has it become naturalized in Europe, that in Italy, Spain, and Portugal it forms a large propor- 
tion of the vegetation. It seems probable that we are indebted to the Moors for their introduction into Europe. Avicenna, a celebrated Moorish physician, is the first who mentions them, and speaks of the oil of oranges. The Moors appear to have penetrated further into India than even Alexander had done, and to have brought the orange from the far North. It does not appear to have been known to either Greeks or Romans.

There are many very distinct varieties of the sweet orange. Risso, a French naturalist, in 1818 published a description of one hundred and sixty-nine. The most remarkable varieties we receive are the St. Michael's, the Blood Red, the Maltese, and the Majorca, or seedless variety. Oranges come to us from the Azores, Lisbon, Malta, and Sicily, in boxes and chests; the imports in 1851 were 300,500 packages, weighing 35,000 tons. (Poole's Statistics.)

The Bitter or Seville Orange.-Citrus vulgaris.This species was known in Europe long before the preceding one. The Moors of Spain cultivated the bitter orange very extensively, probably chiefly for medicinal purposes; all the old plantations which have remained of the Moors' planting are of the bitter kind. They are chiefly used in making marmalade, and the rind is valued for its medicinal 
qualities as a tonic. The number imported is not great, being from 600 to 800 chests per annum.

THE SHADDOcK.-Citrus decumana.-This species of orange was named after Captain Shaddock, who introduced it from China-where it is a native-to the West Indies. It is not a very useful fruit, but from its great size (being the largest of its tribe) and handsome light yellow colour it is highly ornamental. A few hundreds are annually imported from the West Indies.

Forbidden Fruit.-Citrus paradisi.-This fruit, like the preceding, which it strongly resembles, is brought to this country more as an ormamental addition to the dessert than for any other purpose. The pulp of this fruit is sweetish, and not badly flavoured, and the rind is not so intensely bitter as that of the Shaddock. The importation is small and irregular.

Besides these varieties of the orange, two or three others occasionally find their way to this country from the Brazils; they are

1. The Navel Orange, or Larangeira seleta.-Its English name is derived from a protuberance at the top of the fruit.

2. The Common Brazilian Orange-Larangeira da China -thought to be the common China orange. 
3. The Smaller Tangerine, or Larangeira Tangerina pequena.-An elegant little orange, not larger than a walnut; the pulp is very agreeable and the rind highly perfumed.

4. The Greater Tangerine, or Larangeira Tangerina grande.-This only differs from the smaller Tangerine by being much larger.

The Lemon. Citrus Limonum. (Nat. Ord. Aurantiacea.) Several varieties of the common lemon are in use in this country; they usually come in boxes, chiefly from Sicily. The quantity annually received from Messina and Palermo is about 12,000 chests; 3,000 chests are also brought from Malaga and Lisbon, and other places. The most esteemed varieties are-1. The Wax Lemon (C. Limonum ceriescum, Risso), which is most commonly used; 2. The Imperial Lemon (C. Limonum imperiale, Risso); and 3. The Gaeta Lemon (C. Limonum Gaietanum, Risso).

The Lemon is a native of the Himalayan range in India, and is supposed to have been introduced into Europe at the time of the Crusades. It is highly and deservedly esteemed for its acid juice, which is peculiarly grateful and cooling; besides being the most powerful anti-scorbutic medicine with which we are acquainted; indeed, since lime and lemon juice have been ordered by law to be carried by every vessel 
sailing to foreign countries, that dreadful disease, the scurvy, has hardly been known in our Navy and Mercantile Marine. The acidity of the juice in the lemon, and all others of its genus, depends entirely upon the presence of a peculiar acid called citric, which is easily separated by chemical means.

The Lime. Citrus Limetta.

Risso describes seven varieties of the Lime. They are rarely brought to England, and then only in a preserved state, usually in syrup, forming a most delicious addition to our dessert fruits. The variety usually sent thus is the Small-fruited Sweet Lime (C. Iimetta fructu pumilo, Risso). It is about one-third the size of a common lemon, and of a yellowish-green colour when ripe; but in order to preserve the delightful aroma of the rind, it is preserved green, which is the only state in which we see it in this country. The preserved lime comes in very small kegs, of about seven pounds weight, chiefly as presents from Brazil. The Greeks have a method of removing the pulp, and afterwards preserving the rind dry with a thin coating of sugar, in which state we occasionally see them. Although, like all its congeners, it is a native of Asia, it has found its way all over the world, and is cultivated generally where the climate is suitable. 
The Citron. Citrus medica.

Like the preceding, this fine fruit only reaches us in a preserved state, and then usually the rind only. Citron rind either comes candied with sugar, or else pickled in salt and water, for the purpose of being candied here; its use in flavouring confectionery is well known. The citron is the largest of the oval-shaped fruits of the genus Citrus, as the Shaddock is of the round ones. Apparently it was the first known of its genus. Carpenter, in his 'Scripture Natural History,' supposes it is alluded to in the Old Testament whenever the word apple is used, and it is thought to be the

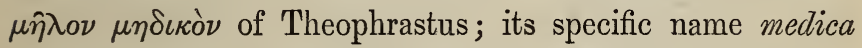
is supposed to be derived from Media, whence it is said to have originated; and not, as might be supposed, from any medicinal virtues. We receive about 70 tons annually of the preserved rind from Madeira.

Besides the valuable fruits yielded by the genus Citrus, it also furnishes us with large quantities of citric acid, of great chemical importance, and the essential oils of orange and lemon peels; of orange flowers (Oleum Neroli); of citronpeel (Oleum Cetronella); of the Bergamot Orange (Oleum Bergamote); and oil of the orange leaves, usually called Essence de petit grain,-all of great value in perfumery. 
The Tamarind. Tamarindus Indica. (Nat. Ord. Leguminosa.) (Plate IV. fig. 15.)

Originally a native of India, this useful fruit has been introduced to the West Indies and South America, where it is extensively cultivated. In tropical countries its agreeable sub-acid pulp is highly esteemed for its cooling qualities; in this country, though now often used as a preserve, it is more generally employed to form medicinal cooling drinks.

We always receive the tamarind preserved, either with or without sugar, and with its outer covering removed. When perfect, the pulp is enclosed in a dry brittle brown pod, from three to four inches in length; when removed, the thick pulp is held, together with the hard brown seeds, by a number of thick root-like fibres, which penetrate it in all directions; the seeds themselves are enclosed in thin tough membranes (endocarps). The East Indian tamarinds are usually darker, and contain more pulp, than those from the West Indies; the former are usually preserved without sugar, but those from the West Indies are more agreeable, being preserved generally in a thick syrup. We are indebted for this fruit to the Arabians, who gave the name from tamar, signifying fruit, and Indus, its native country. Immense quantities arrive from the East and West Indies, 

THE GUAVA. THE MANGO.

Africa, and the Brazils, as presents, besides the imports for commercial purposes, so that it is difficult to ascertain the exact quantity imported, but it cannot be much less than 100 tons annually.

The Guava. Psidium pyriferum. (Nat. Ord. Myrtacea.) (Plate IV. fig. 17.)

This elegant tree is a native of Tropical America and the Caribbee Islands, where its native name is Guayaba, of which its English designation is a corruption. The fruit is somewhat of a pear-shape, and the external rind has the appearance of a ripe apple. Like most other tropical fruits, the guava is very perishable, so that we can only have it in a preserved state; considerable quantities of guava jelly are annually brought from the West Indies and South America.

The Mango. Mangifera Indica. (Nat. Ord. Anacar. diacea.)

Although the Mango is esteemed one of the finest of tropical fruits, and is in India made into jellies and conserves, it only reaches Europe unripe and pickled. In this state it is about the size and shape of a lemon; and from the quantity of mustard usually employed in pickling it, and its own natural colour, it very much resembles that fruit. Only very small quantities are imported. 
Tне Lrтснг. Nephelium Iitchi, or Euphoria Litchi. (Nat. Ord. Sapindacec.) (Plate V. fig. 20.)

This very beautiful addition to our table-fruits is a very recent introduction; the rapid passages lately made to and from China and the East Indies, its native countries, having alone made it possible. The berries are enclosed in a beautifully marked, thin, reddish-brown shell, round, and about the size of a small walnut. Before being packed, they are dried artificially, so that the rich pulp with which they are filled becomes dried and shrivelled up round the seed; even then however the flavour is exceedingly rich and delicate. Few have yet been imported; they have however been sold in the Liverpool fruit-market as low as sixpence a dozen.

Prickly Pear. Opuntia vulgaris. (Nat. Ord. Cactacece.) (Plate V. fig. 21.)

Lately this fruit has found its way into our markets, probably from the south of Europe, where it is now abundantly cultivated, and where it appears to thrive as well as in its native country - the southern parts of North America. It is a very elegant oval fruit, as large, or rather larger than a hen's egg, of a golden-yellow colour, tinted on one side with red or purple, and marked on various parts of its surface with scars, upon which tufts of spines were placed, but 



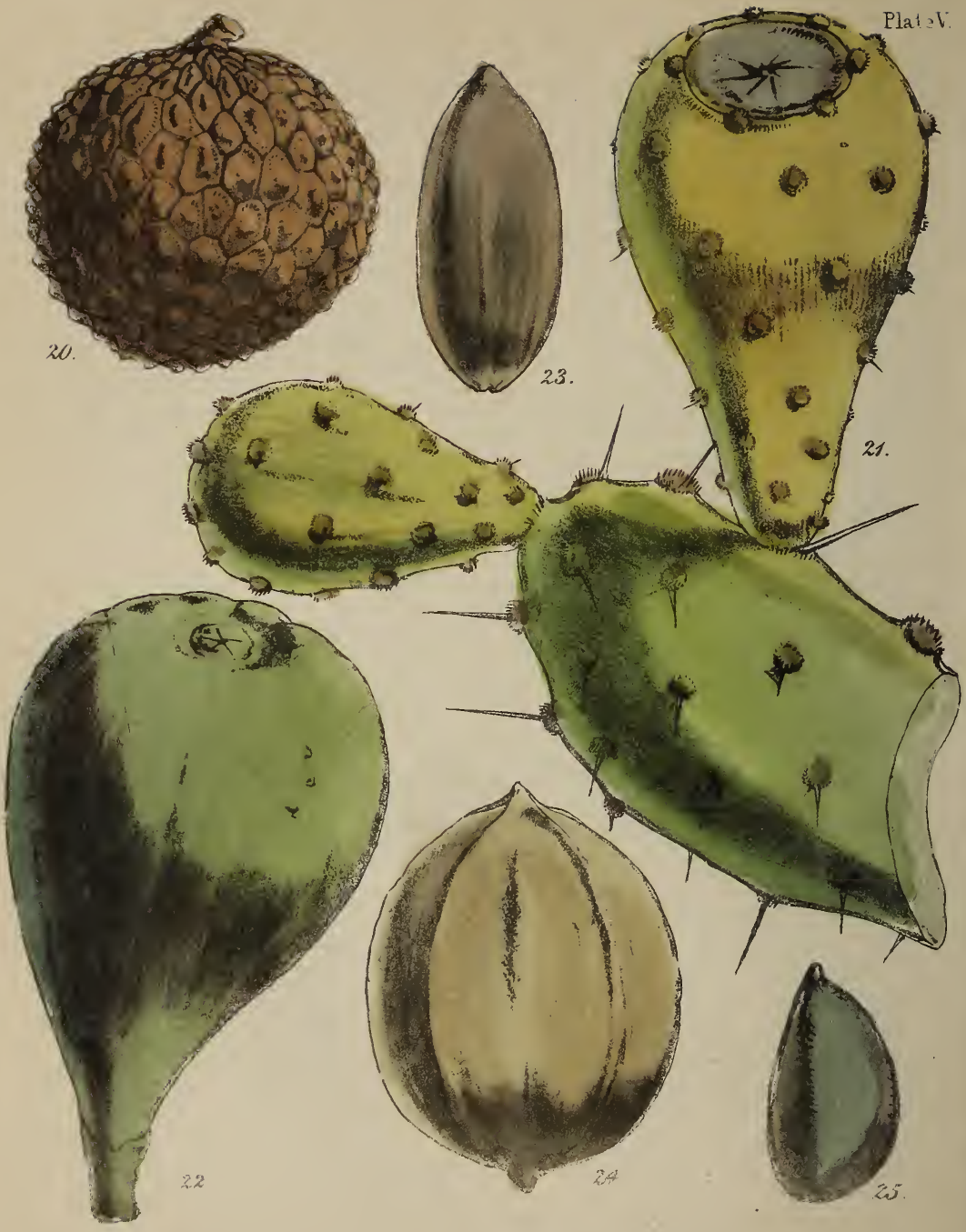

41) Stchu. 21 Frickly Hear. 22 Fig. 23: Pecan Nut. 24. Hickory Nut 25 Pistacio Nut 
which have been rubbed off. As a fruit, it is not much liked in this country, and probably will not be worth importing after the popular curiosity is satisfied. They have been sold in the Liverpool fruit-market at twopence each.

The Banana, Musa sapientum, and the Plantain, Musa paradisiaca. (Nat. Ord. Musacece)

Tropical fruits, produced by magnificent palm-like trees, the stems of which grow often more than twenty feet in height, bearing on their summits clusters consisting of eight or ten large leaves, which are from three to five or even six feet in length, and rounded at each end; they are about eighteen inches in width throughout their whole length, and are of a beautiful emerald-green colour. These leaves, the noblest borne by any known plant, are placed at the end of long stout petioles, the bases of which form the stem; the dried leaves form thatch for the Indian cottages, and serve the natives for many other economic purposes.

The fruit of both species is extensively used as food by the natives of the tropics, throughout which these trees are widely distributed. They are natives of the Cape of Good Hope, the South African Islands, and the islands of the Indian Archipelago. The flower-spike arises from the centre of the tuft of leaves; it consists of an immense number of 
florets, each of which is hidden at first beneath its own perianth, the whole together strongly resembling the heart of some animal suspended, both in colour and shape; as the florets of the base become perfect, the fruit swells out, and the other florets are pushed forward, until the stalk on which they are borne often reaches the length of three feet, and bears an enormous number of fruit, sometimes as many as 150 to 170 or 180 , weighing from sixty to seventy pounds.

Each fruit is about six inches long; it is straight, and about an inch in diameter, rather shorter and thicker in the banana than in the plantain. When ripe, the inner portion consists of a rich sweet pulp, of the colour and consistence of marrow, with the flavour of a fine pear. There are

"Plantains, the golden and the green."

Those which are brought to us are gathered unripe, but, upon being kept long enough, acquire a rich golden-yellow colour. It has been stated that they do not produce good fruit under hothouse cultivation in this country; this however is not quite true: Henry Winch, Esq., of Seacombe, in Cheshire, near Liverpool, some time since, had a plantainhouse in which the fruit was ripened in great perfection. The imported ones are rarely worth eating, and are so little 
esteemed that we have purchased them for twopence each in the streets of London.

The importance of the plantain to the inhabitants of tropical countries can hardly be appreciated by Europeans; but so completely does it form the food of some races, that they might almost be characterized as fructivorous. It admits of being dried or eaten fresh, and in either state is highly nutritious and agreeable.

The Pine Aprle. Ananassa sativa. (Nat. Ord. Bromeliacea.)

The importation of pine-apples from the Bahamas has now become an extensive trade; more than 200,000 were imported in 1851. The pine-apple originally was a native of the tropical islands of America, but, owing to its extraordinary facility for transportation, and its powers of naturalizing itself, it is now thoroughly established in Africa and the East Indies; and its culture in this country, though very costly, is remarkably successful, the fruit produced being far superior to that grown in other and more congenial climates. In a state of nature the pine-apple is not eatable, being so extremely acid as to excoriate the lips and gums. For export to Europe it is gathered before it is quite ripe, and usually reaches England in pretty good condition. The 
English-grown pine-apple usually is from ten to twelve shillings per pound, while the imported ones rarely exceed halfa-crown for the whole fruit.

The pine-apple is that variety of fructification called a sorosis : it consists of a number of bracts which have swollen until they have enclosed the seeds in their rich juicy pulp.

The Water Melon. Cucumis (or Cucurbita) Citrullus, variety Jace. (Nat. Ord. Cucurbitacece)

A small quantity of this fruit reaches the English market annually. It is a large oval melon, with dark green rind; the flesh is white, of a delicate sweet flavour, but very watery and insipid if not quite ripe. We annually receive them from Malaga and Portugal, in a sort of open-worked rush basket, each containing but two or three melons; they are in these baskets suspended to the ceiling of the ship's cabin, and thus avoid bruising and preserve their freshness. They are not usually considered unwholesome.

The Cranberry. Oxycoccos macrocarpus. (Nat. Ord. Vacciniacea.) (Plate IV. fig. 18.)

Probably the kegs of cranberries we receive from North America and Newfoundland contain a mixture of the species above named, with the 0 . palustris and 0 . erythrocarpus. They are preserved in spring-water, and packed in small 
kegs, and are much used in making tarts, for which they are well adapted. The American cranberries are of a slightly oval shape and a bright red colour; they somewhat resemble red currants, but are more than twice as large, and have no remains of the calyx at the top of the berry. About 4000 gallons are annually consumed in England.

The Carob, Locust, or St. John's Bread, 一the Algaroba of the Spaniards and Moorish nations, and the Johannisbrod of the Germans, - is the ripe legume of Ceratonia Siliqua. (Nat. Ord. Leguminosa.)

It is a long flat pod, often six or eight inches long, and nearly an inch in breadth, but not exceeding a quarter of an inch in thickness; the produce of a small, but handsome tree, growing very generally and plentifully in the south of Europe, parts of Germany, France, and the Northern States of Africa. The seeds, which are flat, hard, reddish-brown, and about the size of a lentil, are, like those of the tamarind, enveloped in a pulp. The pulp of the carob is however free from fibres, and is of a very sweet, rather sickly, taste. In times of scarcity it serves as food, and is believed to be the Wild Locust upon which St. John fed. It rarely comes to England, and then only as food for horses, which is its principal use elsewhere. 


\section{CHAPTER III.}

\section{NUTS.}

THE vegetable products which are to be described under this chapter are many of them of considerable interest, both from their importance in a commercial point of view, and also from their botanical associations. The ease with which nuts of all kinds can be preserved and transported from place to place, and the agreeable flavour of such as are edible, render them valuable, either as food or as additions to our dessert fruits. Many of them are so familiar as to need scarcely any description, nevertheless the statistics of the commonest sorts are very little known to the public. Who would imagine, upon seeing the little halfpenny piles of those three-cornered nuts called Brazil nuts, lying upon the apple-stalls in the streets, that not less than 50,000 
bushels of that nut are annually brought to this country, chiefly from the district of Para in the Brazils; and that they there furnish occupation to a large number of the male inhabitants, who are consequently styled Castanheiros, or Castanha (the Brazilian name) gatherers?

As we have mentioned the Brazil nut, we will give its history first.

The Brazil, Juvia, Castanha, or Para Nut, is the fruit of a very fine tree, Bertholetia excelsa. (Nat. Ord. Lecythidacea, Lindley.) (Plate VI. fig. 27.)

It often reaches the height of 120 feet, attaining frequently a diameter of four feet at its base, and often rising a hundred feet before putting forth a branch. The Para forests contain this and an allied tree in great abundance, both yielding sweet nuts in profusion. The nuts are not borne singly, but are packed with most remarkable exactness, to the number of from twelve to twenty, in a hard ligneous capsule, which is nearly round, but inclined to the pear-shape; so hard and so heavy is this great pod, that when ripe, it is dangerous to pass under the trees, for even an Indian's head is not sufficiently hard to withstand the fatal blow of the Castanla Cabomba, as the Brazilians call them. 
Many amusing tales are told of the monkeys, which are so fond of this fruit that they will patiently hammer the capsule for hours with a stone, in order to obtain the en. closed nuts. They watch the fall of the nuts from the trees with great eagerness; and should one of the capsules burst, it is the signal for an amusing scramble. Helter-skelter rush the quadrumanous sentinels of a hundred lofty branches, swinging themselves from bough to bough with their prehensile tails until they close upon the precious juvias, for which they fight with a determination which furnishes another point in their resemblance to the human race. The Indians are said to make use of the imitative propensities of the monkey in order to obtain the castanha crop: they pelt stones and other missiles at the monkeys, who, in return, gather the capsules of the Bertholetia and hurl them at their human opponents. By this means large quantities of these nuts are collected and transferred to the boats. The principal locality for the Para nuts is on the river Aripecurú, a branch of the Amazon; the time for collecting them is winter, when troops of Indian castanheiros ascend the river to obtain the harvest of nuts, upon which they depend for the year's subsistence. They frequently constitute the whole cargo of vessels of considerable burden, and the quantity 


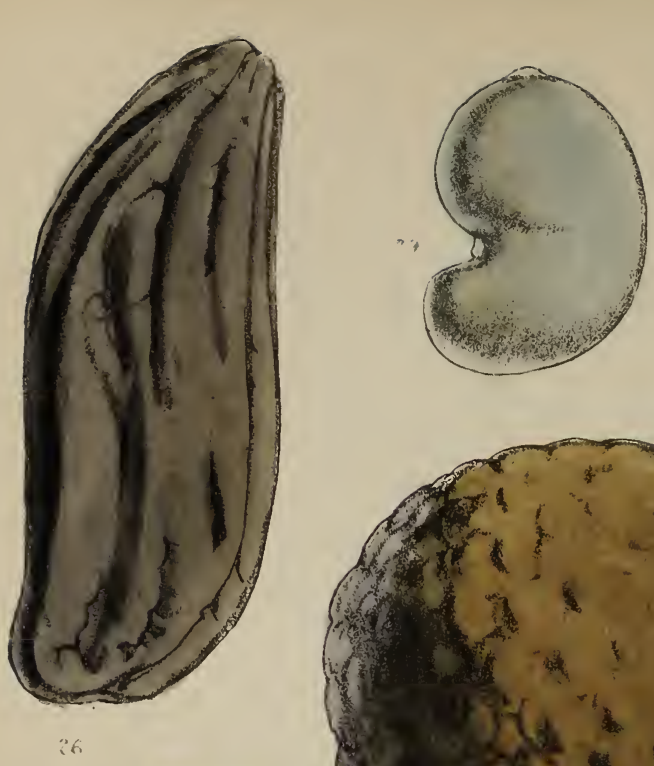
we receive from Brazil is, as before stated, not less than 50,000 bushels. The Para nut is one of the most wholesome of all the hard-shelled fruits, and contains a fine sweet oil, which is often expressed and used by watchmakers, and artists in oil-colours.

Closely allied to the Para nut, is

The Sapucaia Nut. Lecythis ollaria, or Pot-plant. (Nat. Ord. Lecythidacea.) (Plate VI. fig. 26.)

This curious nut is very superior to the last; its flavour is finer, and it is more digestible; but unfortumately these good qualities are as well known to the monkeys, which abound in the Brazilian forests, as to ourselves ; the consequence is, that instead of pelting the castanheiros with them, they eat them, and we get but very few. The trees grow in the same localities as the Pertholetias, but the capsule is rather different: instead of being pyriform, or pear-shaped, it is urn-shaped,-hence its name of Pot-plant,-opening by a sort of lid, which falls off, leaving a large opening sufficient for the nuts to fall out. So eager are the monkeys to obtain the nuts, that they will thrust their hand into this opening, which they do with difficulty, and grasp the nuts; but the orifice which admitted the empty hand will not allow the egress of a full one, and the animal will torment 
itself a long time rather than relinquish its hold. The Indians avail themselves of this cupidity to entrap the monkeys. They open the lids of several capsules, and then throw them under the trees: the greedy monkey will not be satisfied with one pod, but will thrust its hands into two, and will not relinquish its hold; the encumbrance renders its capture easy, and has led to a saying amongst the Brazilians equivalent to our "Old birds are not caught with chaff;" it is, "He is too old a monkey to be caught by a cabomba," the capsule being called by them a cabomba.

The Sapucaia nut is long, rather curiously but slightly curved in the $\mathrm{S}$ form, and the surface is deeply wrinkled longitudinally; the shell is softer than that of most nuts. It is to be regretted that this delicious fruit is not more generally known. The nuts come in small parcels, and are sold cheaply in consequence of the ignorance which prevails respecting their good qualities.

Surahwa, Sovali, or Suwarrow Nut. Caryocar butyrosum. (Nat. Ord. Rhizobalacea.) (Plate VI. fig. 28.)

This large and singular-looking nut is the produce of a gigantic tree found in Demarara, whence we receive the fruit. The Surahwa nut is somewhat kidney-shaped, about half the size of an egg; it grows in bunches, and where the nuts 
are in contact they bear the marks of pressure, being pinched in to an edge on this side, but rounded off on the outer side; the colour is a fine reddish-brown, and they are covered over with close-set rounded tubercles. The kernel is perhaps the most agreeable of all the nut kind; it is as bland and sweet as an almond, with a softer texture, and a milky flavour. Although they keep well, very few are imported into England, probably from the great difficulty in gathering them, in consequence of the magnitude of the trees producing them. The timber is highly valued for shipbuilding, and the oil expressed from the nuts is much esteemed in Demarara; it equals that of the olive in sweetness. It is the Pekea tuberculosa of Aublet.

The Cashew Nut. Anacardium occidentale. (Nat. Ord. Anacardiacea.) (Plate VI. fig. 29.)

The Cashew is a small kidney-shaped nut, of an ash-grey colour, frequently seen in the shops of dealers in foreign dried fruits, by whom however very few are sold. The shell of the nut consists of three distinct parts; the outermost (epicarp) and innermost (endocarp) are hard and dry, the intervening one (mesocarp) consists chiefly of a clammy viscid juice, of such an exceedingly acrid nature, that persons attempting to crack the nut in the mouth are sure to 
suffer severe excoriation of the lips and tongue. Like many other noxious vegetable secretions however, heat destroys the acridity of the Cashew-nut husk; it is therefore roasted before being eaten, and in that state is a great delicacy. The tree producing this nut is of considerable size, with very small flowers; its most remarkable feature is, that the disc of the flower to which the nut is attached continues to grow after the flower has fallen, until it is of considerable size, giving the appearance of a kidney-shaped nut growing out of a large-sized fruit; this enlarged fruit-like disc is used as a fruit, and its juice is fermented into a kind of wine in the West Indies.

The Marking Nut. Semecarpus Anacardium.

This belongs to the same Natural Order as the preceding, and is closely allied to it; it is however very different in shape and colour, being somewhat like a tamarind-stone, but rather longer, with a whitish scar at the base, marking its place of attachment to the receptacle. It has the same marked division of the pericarp into three parts; the intermediate one is fluid, of a remarkably fine black colour, and is used extensively as a black varnish, for which purpose it is principally imported, although when roasted the nuts are as sweet as those of the cashew, but too small to repay the 
PISTACHIO NUT. SWEET ALMOND.

trouble; they are however occasionally eaten. It is a native of the East Indies, where its black varnish is used for markıng linen, as well as varnishing lacquer-work,-hence its name of Marking Nut.

The Pistachio Nut. Pistacia Lentiscus, also belonging to the Anacardiacea. (Plate V. fig. 25.)

Is much cultivated in the Greek islands, especially Chio (where its gum is also gathered), and many parts of Southern Europe. The nut is of a reddish-green colour, about an inch long, and not unlike a radish-pod in shape; the kernel is of a bright green colour and very agreeable flavour; the nut splits into two valves. The Turks and the Greeks both use this fruit in great abundance, hence the cause of its reaching us only in small quantities. Formerly it was much used in this country as a substitute for almonds.

The Sweet Almond. Amygdalus communis, var. $\beta$ dulcis. (Nat. Ord. Drupacea, De Candolle.) (Plate VI. fig. 30.)

The sweet almond is too well known to need a description; there are however several very distinct varieties. 1. The Jordan Almonds, which, notwithstanding their Oriental name, all come from Malaga; they are the finest of all. Jordan almonds are longer in proportion than either of the following varieties, and their skin is clear and free from 
brown dust; they are not often imported in the shell. 2. The Valentia Almonds, which we receive from Spain; they are not quite so long as the Jordan variety, but are broader, and the skin is covered with a fine dust of the same colour as itself; sometimes imported in the shell. 3. The Barbary and Italian Almonds, which appear to be the same variety; they are shorter, rounder, and smaller than either of the other sorts ; they are most frequently imported in the shell.

The almond is very closely allied to the peach, which is in fact a species of Amygdalus (A. persica), and, like it, consists of a fleshy fruit, containing a seed enclosed in a hard shell or putamen (endocarp). In the almond this fruit is not so succulent as in the peach, and does not adhere to the shell; when ripe it becomes hard, splits, or dehisces, so that the nut drops out. The almond-tree giows to about the same size as the common plum, and in this climate its flowers are produced very early in the spring, before any leaves appear ; this habit furnished the poet Moore with the following poetical simile :-

"The hope, in dreams of a happier hour,

That alights on misery's brow, Springs out of the silvery almond-flower,

That blooms on a leafless bough." 
THE BITTER ALMOND.

The first mention made of almonds is in the following verse of Scripture: "And their father Israel said unto them, If it must be so now, do this; take of the best fruits of the land in your vessels, and carry down the man a present, a little balm, and a little honey, spices, and myrrh, nuts, and almonds," Genesis xliii. 11. They are most probably natives of Syria and the northern parts of Africa, whence their cultivation spread over most parts of Asia, and into Greece. It was late before the Romans became acquainted with this fruit, which they at first called "Greek nuts." They are merely used as a dessert fruit and in confectionery. Poole, in his 'Statistics of British Commerce,' shows that the annual consumption of this nut in Great Britain averages 500 tons, the value of which in round numbers is $\$ 48,000$ sterling. A large quantity of oil may be expressed from the seed, but the value of the sweet almond as a fruit is too great, and the bitter variety is consequently preferred for expression.

The Bitter Almond. Amygdalus communis, variety a, amara.-This variety is received chiefly from Barbary, where it forms a staple article of commerce. Its principal use is for the expression of the fixed, and distillation of the essential oil; it is however used in confectionery, for imparting 
its agreeable flavour. The bitter almond is much smaller, rounder, and thicker in proportion than either of the sweet kinds; its essential oil is a dangerous poison, consequently the fruit is not a safe one to eat in any quantity; its bitter flavour will however prevent most persons from eating it. The imports are about 300 tons per annum.

Thu Hazel Nut. Corylus Avellana. (Nat. Ord. Corylacece.)

This is the most familiar of all the edible nuts, and is certainly one of the most ancient in its use, being also mentioned in ${ }_{2}$ the same verse, with the almond, above quoted from Genesis. The nut is found growing wild in all the forests of the temperate parts of Europe; it is also abundant in many parts of Asia. There are the filberts of Jerusalem,

"And sweet nuts

From the far groves of Samarcand."

The Jerusalem Filbert, one of the Asiatic varieties, is occasionally imported in small quantities; it has the shape of the common filbert, but is rather flatter; the kernel is dry, and by no means equal to the generality of nuts.

Another Asiatic nut, the Red Smyrna (Corylus Colurna), is remarkable for the thinness of its shell; it is much used 
for expressing oil; its edible qualities are not equal to the European varieties, large quantities are however occasionally brought. From Spain we receive two varieties of the common hazel nut: one, called the Black Spanish, is the fresh fruit; the other, called the Barcelona, is probably the same variety of nut, but is always kiln-dried before exportation. The Filbert (a corruption of full-beard) and the Cob-nut, two improved varieties of the common nut, are occasionally brought from other countries, but they are usually cultivated in England in sufficient quantities to supply the demand.

The hazel nut belongs to the Linnæan Class and Order Monœcia Polyandria, that is, the stamens and pistils are in different flowers, but on the same plant. Like most others of the Natural Order Corylacea, it produces the stamen flowers in the form of catkins, which make their appearance in autumn, and keep on growing until February, when the pistil flowers are first seen; these are not so conspicuous as the male catkins; they consist merely of a bud, similar to the leaf-buds, with the pistils projecting in the form of a small crimson feathery tuft. It requires a close inspection to find the pistil flowers, but their beauty will well repay the trouble. In Kent, where cob-nuts and filberts are very much cultivated, the fertility of the pistil flowers is ensured 
by drawing a bunch of the catkins, with ripe pollen, over them.

The following are the varieties of the common hazel :-

$\begin{aligned} \text { British } & \left\{\begin{array}{ccll}\text { Corylus Avellana alba } & \text { White Filbert. } \\ " & " & \text { rubra } & \text { Red Filbert. } \\ " & " & \text { grandis } & \text { Great Cob. } \\ " & " & \text { glomerata } & \text { Clustered Cob. } \\ \text { Spanish } & \text { " } & \text { crispa } & \text { Frizzled Cob. } \\ " & " & \text { Barcelonensis } & \text { Barcelona. } \\ " & " & \text { variegata } & \text { Variegated. } \\ " & " & \text { ovata } & \text { Ovate-fruited. }\end{array}\right.\end{aligned}$

The vast quantities imported into this country are almost incredible, especially as the consumption is chiefly amongst children; in 1850 the imports exceeded 140,000 bushels, value $£ 90,000$. A small portion only of this enormous quantity is consumed in the manufacture of nut oil, which is esteemed by watchmakers, and also by artists in oilcolours.

The Walnut. Juglans regia. (Nat. Ord. Juglandacea.) The Natural Order to which the Walnut belongs is closely allied to that of the hazel nut. The fine, tree which produces it is pretty well known; it grows to a large size, 
and has large oblong-ovate leaves, of a bright green colour and very agreeable odour; they are sometimes used in dyeing. Walnut-trees are pretty widely diffused, not only over Europe, but also in Asia. In Cashmere they are cultivated to an enormous extent for the valuable oil they yield, which surpasses even linseed in its drying qualities; it is said that in that country 12,000 ass-loads of this nut are annually taken to the oil-mills.

There are few nuts of more agreeable flavour than the walnut, consequently it is a great favourite at the dessert table; but very few are imported, in consequence of their ripening well in this country, and they will not bear a long voyage without being kiln-dried, a process which certainly spoils them; they are however grown in most parts of England as timber-trees, and it is to be regretted that they are not much more cultivated, as they are very valuable, if it were only on account of their very ornamental timber. The Germans are aware of the value of the walnut-tree, and cultivate it assiduously. We receive about 30,000 bushels, the principal portion of which is imported into London from Germany; a few also come from France and Italy. From America we receive the Hickory and Peccan nuts, which also belong to the walnut tribe (Juglandacea). 


\section{Tine Hickory Nut. Carya alba. (Plate V. fig. 24.)}

The produce of one of the finest forest-trees of North America. The nut is smaller than a walnut; the shell very smooth and light-coloured or whitish; it is marked longitudinally with three or four ridges or sharp angular keels; it is extremely hard; the kernel closely resembles the walnut in appearance. The wood of the tree is much valued for its toughness, lightness, and elasticity. The nuts are imported only in very small parcels.

The Peccan Nut. Carya olivaformis. (Plate V. fig. 23.) This, as its name implies, is an olive-shaped nut; it is also about the size of an olive, but longer and narrower; its colour is a light reddish-brown, and the shell is not so hard as that of the hickory nut; the kernel is very similar in flavour to the walnut and hickory ; they are not imported in large quantities. One or two other species of the walnut tribe are occasionally imported, such as the Butter Nut (Juglans cinerea) from Canada-a true walnut,-and the Hog Nut (Carya porcina); they are however of very rare occurrence.

The Chestnut. Castanea vesca. (Nat. Ord. Corylacea.) This well-known fruit, though a native of Britain and other temperate parts of Europe, does not bring its fruit to 
any very great perfection in this country, hence we import nearly all the chestnuts from Spain, whence they are usually called Spanish chestnuts. In that country they come to the greatest perfection, and are produced in such profusion as to constitute a staple article of food to the agricultural classes. Although not particularly nutritious, they are, especially when roasted, much more easy of digestion than most of the edible nuts; there is however one danger to children in eating them, and that is from imperfect mastication, without which they are difficult of digestion, and are apt to create serious and even fatal stoppages of the bowels. Several such cases are on record, but it has always been with children; and post mortem examinations in most cases have shown the duodenum, or second stomach, wedged up with little blocks of chestnut. The quantity of chestnuts imported amounts to upwards of 50,000 bushels annually.

A very small but remarkably sweet chestnut is now occasionally imported from the United States of America; it is the produce of a distinct species, called Castanea Americana.

The Ground Nut. Arachis hypogaa. (Nat. Ord. Leguminosa.) (Plate VI. fig. 31.)

This curious nut is the produce of a plant which is indigenous to, and extensively cultivated on, the western coast 
of Africa, where it constitutes a large proportion of the food of the negro inhabitants; the native name is Munculi. It is an annual plant, of a trailing habit, with yellow pea-shaped flowers, produced from the axils of the leaves in bunches of five or seven, close to or even under the ground; if below the surface, they are fertile, and produce peculiar roundish-oblong pods, having usually two, but sometimes four, red-coloured seeds, which are about the size of field-peas, and have very much their flavour. They are now naturalized in South and North America; indeed, some botanists are of opinion they are natives of South America, but there is little doubt of their African origin, and that the slaves introduced them to the New World. They are cultivated to a very great extent in all parts of the North and South American States and in the West Indian Islands; they are also cultivated in the East Indies and Cochin China, but in these places chiefly for the fine limpid oil which the seeds yield by expression.

The most curious circumstance connected with this plant is the subterranean habit of its flowers and seeds; the pod is pushed into the soil, and there ripened. This peculiarity is found in another closely-allied genus called Voandzeia, which produces very similar seeds, known in Surinam under 
the native name Gobbe. The seeds of both these plants are boiled by the negroes and eaten as peas. The ground-nut is used in various ways in North and South America; it is however most generally roasted. In South Carolina it is roasted, and used as chocolate; in Paris it is cultivated as a vegetable, and although requiring the assistance of a hotbed in raising, it nevertheless is by no means uncommon. Its curious habit of burying its pods causes it to be occasionally cultivated in our hothouses as a curiosity. They are now sold by most dry-fruiterers, but the bulk of those imported find their way to the oil-mills. The supply is irregular,sometimes several hundred quarters in the year, and at other times none at all. The pod seems made of a material not unlike that of reeds, is very irregular in shape, and covered with small depressions between longitudinal veins. It is never likely to be much used as an edible fruit in this country, being in no respect superior to the common grey pea of our fields.

The Cocon or Coker Nut. Cocos nucifera. (Nat. Ord. Palmacea.) (Plate IX. fig. 44.)

This familiar nut is generally known in commerce by the name Cocoa-nut; it is the fruit of a fine species of Palm. To the inhabitants of the tropics the cocoa-nut is invaluable; 
it furnishes them with a sweet wholesome food, a refreshing drink, a material for cordage, and various domestic utensils, besides a valuable oil, which is used for many economic purposes. The nuts are enclosed in an outer husk, which has three flat sides, terminating at the top in a blunt point, consequently a transverse section of the entire nut would be triangular; this outer husk is composed of a large mass of very strong fibres, which form a compact shell externally, but are very loose inside. This product will be further mentioned in the chapter on vegetable fibres. Within is the nut, enclosed in a very hard oval shell, about a quarter of an inch in thickness; this is used in many ways by the natives of warm countries in making various domestic utensils. The peculiar triangular form of the cocoa-nut has been pointed out as a special provision for its dissemination; thus, growing as it does frequently near the shores of the sea and rivers, its large seeds drop in the water, and their shape particularly adapts them for sailing: one edge being downwards forms the keel, while the upper surface being flat is acted upon by the wind, and propelled by it along the surface, until it reaches some coral-reef, atoll, or other shore, where, being stranded, it vegetates and rises to be a magnificent palm, affording shelter and food in abundance. The 
coir husk, too, assists in this economy of nature : as the exposure to moisture and the heat of the sun are conducive to vegetation, and as the salt-water would destroy the young plant if its tender shoot should be pushed out into the sea, a curious arrangement takes place; as soon as the shoot and root push out from the foramen, they take a direction towards the other end of the nut through the mass of coir fibre-this gives an increased weight to that side of the nut which acts as ballast, keeping it downwards and under water. The coolness to which the shoot is thus exposed assists in keeping the vegetative power in check; but no sooner has it landed upon some congenial soil than it throws out its strong roots, and soon renders a barren island fertile and verdant.

The quantity of nuts produced by one palm is immense: at least from twenty to twenty-five are borne monthly, and as the nut is very nutritious, their utility is very great in tropical climates, where field labour would be intolerable. Besides the nut, coir-fibre, and cocoa-nut oil, the cocoapalm produces Toddy, or Palm-wine, which, though made from various palms, is chiefly made from the cocoa-palm. It is usually asserted that toddy is procured by cutting out the cabbage or the young leaves constituting the heart of the palm-tree, when, from the wound thus made, the sap flows, 
which, when fermented, forms toddy, and then the plant dies. This is not the case; it is the spadix or flowering head which is cut, and from which the toddy flows. This prevents it from fruiting at the time; but as the cocoa-nut palms afford twelve crops in the year, it is only one month lost, if the operation be well managed. The cocoa-nut palm fruits monthly, and where it is cultivated, care is taken to thin the clusters, so as to allow each spadix to produce only from seven to ten nuts, otherwise they are inferior both in quality and size. Mr. Braithwaite Poole, in his Statistics, states that in 1850 the imports were $1,575,000$ nuts, or the enormous weight of 1575 tons; and be it remembered the cocoa-nut is merely used as a luxury, chiefly by children, and is not imported for any other economic purpose. 


\section{CHAPTER IV.}

FECULAS, OR STARCHES.

The Starches of commerce are numerous and highly interesting; they are well worthy of attention from the extraordinary influence they exert in the economy of vegetation. Unfortunately however much obscurity invests their history, which, as it requires the nicest microscopical investigations to elucidate, must still occupy both time and attention. Starch is found to exist in all plants, and although it appears first as a secretion of the plant-cell, it appears eventually to assume the character of a cell itself:

Leeuwenhoek, the eminent German microscopist, asserted that starch granules were cells having soluble contents, but an insoluble case; this theory was also taken up by many other philosophical investigators, especially those of the 
French schools. However, Payen, Persoz, and Fritsche, eminent investigators of this highly important point in vegetable physiology, assert quite the contrary. According to these physiologists, starch granules are made up of concentric laminæ, which are superimposed upon one another, and that both their exterior and interior parts consist of the same material, being a substance peculiar to the vegetable kingdom, insoluble in cold water, but capable by heat of being converted into soluble sugar and gum.

Starch is the nutritive matter of plants, which, like the bees, lay up a store for the winter season; but as light has the effect of converting it into chlorophyle, or the green colouring matter of plants, nature designs that the reserve store shall usually be deposited in the underground roots, removed from the influence of the sun's luminous rays. Here its quality of being insoluble in cold water is of immense importance, because, if soluble, the rains of winter would dissolve and wash out the store thus laid up,-from this it is protected by its insolubility; but when the warmth of spring and the vitality of the plant begin to operate upon the starch-granules, they are converted into sugar and gum by the influence of a peculiar ferment called diastase; after this conversion they are easily soluble in the juices of the 
STARCH.

plant, and are carried into circulation for the nutrition of the new vegetation. These operations are not merely chemical; they depend also upon the vitality of the plant. Dr. Charles Inman, of Liverpool, in a paper read before the Literary and Philosophical Society of that town, has shown that the fall of the leaf, one of the most singular phenomena of vegetable life, is caused by the deposit of a ring of starch-globules at the base of the petiole, where it is articulated to the stem; this ring, continuing to increase internally, eventually cuts through the petiole, and so dissevers the leaf from the plant. May we not then assume that the decreasing influence of the sun towards autumn, and the exhausted vitality of the plant, acting together, prevent the conversion of the starch, formed by the secretory cells of the leaf, into chlorophyle, and hence the leaf loses its green colour, becomes yellow or red, and finally, from the deposit of starch in its petiole, falls to the ground? We have however much to learn respecting the nature of starch; even the form of the granules, in different species of plants, is a matter of much dispute, and most authors give different delineations (we give two in Plate XI. fig. 56, 57, from good authorities).

When perfectly pure, all starch is the same in appearance 
and properties, being a fine white, silky, or glistening-looking powder, which will not bind together by pressure between the fingers. By mixture with other matters belonging to the various plants from which it is procured, it however assumes other characteristics, which are permanent in many species in so complete a degree that the starch-granules offer an indication of the species of the plant.

All kinds of grain yield starch in abundance. Wheat starch is manufactured in very large quantities, but rarely to serve for food, its principal use being as a stiffening material for textile fabrics ; its mode of manufacture is as follows:-wheaten flour is steeped in cold water for two or three weeks; this causes acetous fermentation, which dissolves a large portion of the gluten by which the starch was held combined; the residue is washed thoroughly with clean cold water upon fine sieves; here the starch and water pass through, while the bran and a further portion of the gluten remain behind to be rejected. When the starch is thus washed thoroughly pure, it is placed in wooden boxes with perforated bottoms, lined with canvas, through which the moisture drains; when nearly dry, it is cut into square masses and placed on porous tiles to absorb any remaining moisture, after which it is finally dried in a stove; 
STARCH.

while drying, it splits into those curious long angular fragments in which we usually see it. Latterly the Germans have sent us some very fine samples of wheaten starch in thin round sticks, about three inches in length and the sixteenth of an inch in diameter; we however import very little wheaten starch, owing to the high duty, -not more than two to three tons are imported annually.

Potato starch, made from the common potato, Solanum tuberosum (Solanacea), by an exactly similar process to that detailed above, is an article of considerable importance as an import, and also as a cheap substitute for wheaten starch ; it is always in the form of a fine glistening powder, and is usually imported from France and Holland, in sacks and bags. It is very extensively used in the manufacturing districts for dressing calicoes, muslins, etc. When heated to $210^{\circ}$ starch becomes altered from a substance insoluble in cold water to one perfectly soluble both in cold and hot water; this is in appearance the same as the starch, but when dissolved has all the properties of gum, and is now extensively used under the name of British gum, which is employed for various purposes, especially rendering postagestamps and envelopes adhesive. Potato starch so altered is called Dextrine. It also is imported in sacks from France; 
when dissolved this is British gum, which, besides its other applications, is of immense use in dressing muslin and crape goods. Of potato starch and dextrine, as much as 300 tons have been imported from France, Holland, and Germany in one year, but its importation is very uncertain. The quantity manufactured in Great Britain is enormous; the returns however include wheaten starch, and show that of the two kinds of starch mentioned, not less than 20,000 tons, of the value of $£ 460,000$, are annually manufactured.

Arrow-Root (West Indian), the produce of Maranta arundinacea. (Nat. Ord. Marantacea.) (Plate XI. fig. 53.)

This fecula is remarkably pure, and is in the form of a fine white glistening powder mixed with small lumps, which are however easily pulverized between the fingers; its starchy character is easily seen by the microscope, under which it is seen to consist of small granules concentrically laminated; the rings are very fine, and gradually increase in size from an extremely small one, which seems apparently to occupy the apex, and has been named the hilum. West Indian arrowroot resembles potato starch, but is of a yellowish-instead of a bluish-white colour, and the individual granules are less translucent. The fecula is not, as might be supposed from the name, made from the root, but from a peculiar un- 

derground stem, or rhizome, which, whilst subterranean, is white and scaly, and contains the fecula in abundance; but it is afterwards pushed out of the ground and forms a new plant, for the nutrition of which the starch is intended. In procuring the arrow-root, these rhizomes are taken up and beaten to a pulp in wooden mortars; this mass is then well washed in cold water, and the milky-looking fluid is passed through a fine hair sieve and left to settle; the white sediment is then again washed with pure water, from which it is allowed to subside; the water is then decanted, and the white sediment laid to dry upon sheets exposed to the sun; it is then the arrow-root of commerce. That from Bermuda is most celebrated.

East Indian Arrow-root is the starch procured from a species of Turmeric, Curcuma angustifotia (Nat. Ord. Zingiberacea), (Plate XI. fig. 54).-This plant produces small rhizomes, in which a remarkable pungency and colouring matter exists; from the sides of these rhizomes spring a number of fibrous continuations of the rhizome; upon many of these fibres are small round tubers, entirely free from the taste, smell, and colour of the main rhizome. These tubers, containing the starch in abundance, are collected and submitted to washing processes similar to that of the West 
Indian arrow-root, and the result is a fine white starch, but differing from the last in its more opake appearance and want of firmness between the fingers. There are two or three varieties, especially one of a brownish-white colour, probably derived from another species of Curcuma.

Brazilian Arrow-root.-This is starch procured from the roots of the Manihot utilissima (Nat. Ord. Euphorbiacece), (Plate XI. fig. 58). This shrub is also called Janipha Manihot; it rises to the height of twenty to thirty feet, and has a large tuberous, or rather swollen root, the juice of which, like that of all portions of the plant, is of a most deadly poisonous character; this poison is however rendered perfectly innocuous by heat. The roots, which sometimes weigh from twenty-five to thirty pounds, are rasped whilst fresh, and the pulp thoroughly washed; this takes place after the juice is drained out. The juice, though a deadly poison, when once boiled becomes the delicious sauce called Cassaripe, so much esteemed by epicures. When the pulp is washed with cold water, the starch is separated in a very pure state and dried in the sun; it is then in the form of fine white powder, and is known in commerce under the name of Brazilian arrow-root. Its native names are Moussache and Cipipa. 
The term Arrow-root is derived from the use to which the American Indians apply the rhizomes of the true arrow-root; they believe that when bruised and applied to the wounds of poisoned arrows, they are an antidote to the poison. The various species of arrow-root are chiefly used as nutritious diet-food for invalids; they are also employed for making puddings and other light kinds of food, which are esteemed very digestible and nutritive, when combined with milk. We have imported, of all the kinds of arrow-root, about 400 tons annually.

TAPIOCA is also produced by the Manihot utilissima (or Janipha Manihot); the only difference in the preparation is, that the starch, after being washed out of the pulp of the root, instead of being dried by the sun, is dried upon hot plates, by which process it is partially converted into dextrine; whilst drying in this kind of way, it is stirred with iron rods, which break up the pasty mass and give in drying the very irregular rocky appearance peculiar to tapioca. This preparation is much used in making puddings. The quantity imported has of late years immensely increased,about 600 to 800 tons are now received annually.

Cassava, Mandioca, Farinha, or Farine de Manioc.These also are preparations from the roots of the tapioca 
plant. Instead of washing the starch from the pulp, the pulp is dried upon hot metal plates, and afterwards roughly powdered; this rough powder, according to its fineness, is called by the various names above mentioned. It is much used in the Brazils to make flat thin cakes, like the oaten cakes of Scotland, which are known as Cassava bread; very large quantities of this preparation (Mandioca flour) are imported and sent to the manufactories, to serve as a substitute for common starch. The Portuguese name Farinha is also often used in commerce to designate the varieties of Mandioca meal.

Tous Les Mors.-The produce of an unknown species of Canna (Nat. Ord. Marantacea); it is usually said to be produced by Canna coccinea, from the rhizomes or underground stems; but the real species cannot be named with certainty, and its true history must remain to be determined by future investigation. Many of the useful products of the vegetable kingdom are enveloped in the same uncertainty regarding their origin.

Tous les Mois is very much like a fine quality of arrowroot; it is however very distinct when examined microscopically, the particles being larger than those of any other known fecula. It all comes from the island of St. Kitt's, 

where it is extensively manufactured by a process which is not known, but said to be very difficult; this however can only arise from the tenacity with which the starch granules are held in the cellular tissue, and the consequent difficulty in washing them out. About 10 tons are annually imported. It is entirely confined to dietetic purposes.

SAGO.-The fecula of several species of Palms, but chiefly from Sagus Rumphii (Plate IX. fig. 43), S. lavis, and Saguerus Rumphii.

These Palmacece are palm-trees of moderate size, from twenty to thirty feet in height, and usually found in swampy or marshy situations. The Sago-palms have thick stems, which externally are hard like that of the bamboo; the interior is filled with pith, or cellular tissue, which contains an enormous quantity of starch or sago. This large supply of vegetable nutriment is provided for the maturation of the fruit; for no sooner has the flowering of the palm ceased, and the fruit begun to form, than the cells, with their store of fecula, all disappear, leaving the stem quite a hollow shell. This is one of those wondrous provisions of an allwise Creator for carrying out the beautifully varied arrangements of the Vegetable Kingdom, and at the same time furnishing food to his favoured creature man. 
In order to procure the sago, it is of course necessary to cut down the tree; this is done before the flowers are developed; the stem is then cut into short lengths and split open, the pith scraped out and submitted to repeated washings, which separate the sago. By this operation the sago sinks in the water, and the fibrous and cellular matter of the stem floats and is easily separated; the sago is afterwards dried in the sun, and constitutes the sago-flour or sago-meal of commerce, which is now used as starch by our manufacturers in considerable quantities; it is also used as food by the natives of the Indian Archipelago, where the plants are native, and where they are extensively cultivated. In order to fit this sago-meal for food in the European market, the natives submit it, whilst wet, to a curious process of granulation, which, besides forming it into small round translucent beadlike grains, gives it a pearly lustre. The exact method of granulating sago is unknown to Europeans.

There are two or three very distinct varieties of sago known in commerce. The most common is the pearl sago, which is in grains about the size of coarse sand, but beautifully rounded. The granulated sago is in larger grains, about the size of a mustard-seed; this is an elegant preparation, which is coming into more general use; and lastly 
the brown sago (Sagu fuscum of Pereira*) which is rarely met with; a sample of it was shown in the Liverpool Collection of Imports at the Exhibition of 1851 ; it was almost as large as the confection called caraway-comfits, of a greasy appearance and reddish-brown colour; indeed, it was not unlike radish-seeds, but rather larger ; this is most usually known in the market as Borneo Sago. Nearly all the sago we receive comes from Singapore; but that place is merely the entrepôt : it is produced in most of the islands of the Indian Ocean and forwarded to Singapore, whence it is imported to Europe. The quantity brought to the United Kingdom has immensely increased within the last few years : it now amounts to nearly 5000 tons per annum (including all the varieties). It is extensively used as food, being very palatable, nutritious, and cheap: but the sagomeal or flour is principally consumed in the factories as starch for stiffening textile fabrics.

Maize Starch.-This is the starch from Indian corn; it has scarcely yet become a commercial article; a few lots only have been imported for experiment, and the Americans exhibited samples of it in the Great Industrial Exhibition under the name of Oswego Starch.

Rice Starch is almost, if not entirely, home-manufac* Pereira's Elements of Materia Medica and Therapeutics. 
tured; it is sold under the name of Patent Starch, and is now very extensively used both in the laundry, and also in the muslin manufactories.

Tahiti Arrow-Root, or Otaheite Salep, is the fecula produced by Tacca pinnatifida. (Nat. Ord. Taccacea.)

The Tacca pinnatifida is a native of the Molucca Islands, and also the islands of the Pacific Ocean; it is also extensively cultivated in various parts of China and India. Its tuberous roots under cultivation acquire considerable size, and are eaten by the natives of China, Cochin China, and various other parts of the world; they are however very bitter. The arrow-root formed from these tubers comes from Tahiti, and is there manufactured chiefly by the native converts to Christianity, under the superintendence of the missionaries. It is prepared by rasping the soft fleshy roots upon a rude kind of rasp, made by winding coir yarn round a piece of board; the rigidity of the cocoa-fibre (coir) is quite sufficient to effect the purpose of rubbing the roots to a pulp, which is then washed with sea-water, and the fecula, which is abundant, is deposited from the water used in the process. It is found in commerce rarely, and is usually in packets, labelled "Arrow-root prepared by the native converts at the Missionary Stations in the South Sea Islands." 
The substances remaining to be mentioned under this chapter, although they cannot be called starches, yet depend for their value, so much upon the fecula they contain, that they cannot be considered altogether out of place in being ranked with the true feculas.

SaLeP, or SALOOP. - The roots of various species of terrestrial Orchidacea.

The imported Salep consists of the small dried tubers of some Orchideous plants: they have a horny appearance, being slightly translucent, hard, and of a dirty yellowishwhite colour. It is imported from Smyrna and Constantinople, but Dr. Royle says it is collected in Cashmere, and consists of the tubers of Eulophia campestris. Large quantities find their way into the bazaars of India under the names of Salep hindree, Salep misree, and Salib misree; the last-mentioned name distinguishes a variety of the article which is obtained from Caubul.

The salep of commerce contains a large quantity of the peculiar gummy principle bassorine, besides a considerable proportion of amylaceous matter, which renders it highly nutritious. For use it is reduced to powder, and being boiled in water, is used as a diet-drink ; formerly it was very extensively used in London as a breakfast drink amongst 
the lower classes, but the cheapness of tea and coffee has driven this beverage nearly out of use; however, a solitary saloop-vender may still occasionally be seen with his tin apparatus for holding and keeping it warm; they are found only at daybreak, usually in the purlieus of the markets.

Semolina, Semoletta, Semola, Seurola rarita, Soofee, and URENA, are names used to designate a product of wheat. In some countries the wheat has its starch and gluten much more intimately combined than in others, the consequence is, it is harder, and is termed flinty. In grinding this wheat, some parts resist the millstones, but get rounded by the attrition; these hard parts are usually very small and round, but are occasionally oval; they fall into the furrows of the millstones, from whence they are collected, and, according to the fineness of their size, they are called by one of the above names, and are usually imported from Italy.

Manna-croup exactly resembles Semolina; it comes from Russia, being usually imported in small quantities in the timber-ships which come from the Baltic. They all form admirable food for infants, and are much and deservedly esteemed as materials for making light puddings for invalids. The imports of all sorts only amount to about 15 tons per annum. 


\section{7}

\section{CHAPTER V.}

\section{SPICES.}

"Now gentle gales,

Fanning their odoriferous wings, disperse

Native perfumes, and whisper whence they stole

Those balmy spoils; as when to them who sail

Beyond the Cape of Hope, and now are past

Mozambic, off a sea north-west winds blow

Sabean odours from the spicy shore

Of Araby the blest; with such delay

Well pleased, they slack their course, and many a league,

Cheer'd with the grateful smell, old ocean smiles."

By the term Spices, a variety of substances are understood. "The spices of Arabia" have, from the remotest ages, been proverbial; nevertheless, with all its spice-bearing celebrity, Arabia sends no spices to us, and it is doubtful if any are now yielded by that country. There is reason to believe 
that the designation was applied to all aromatic vegetable products; and as many of these were doubtless produced in Arabia, and her sea-girt boundaries made her the mart for similar products from other countries-thence arose her fame as "the land of spices and frankincense." There is reason too for supposing that a large trade was carried on in these productions, chiefly arising from the use of spices and the aromatic gums in embalming the dead, which was in those times the greatest use of such materials. Even in our time the term Spice applies to the most dissimilar parts of plants, as the seeds, roots, bark, flowers, etc. ; and the only definition of the term we can give, is - a vegetable product which has an agreeable aromatic and pungent flavour, rendering it useful in the preparation of certain kinds of food and condiments. The most important of the spices is

Cinnamon.-The dried under-bark of the Cinnamomum Zeylanicum. (Nat. Ord. Lauracece) (Plate III. fig. 13.)

At present the production of the true Cinnamon is chiefly confined to the island of Ceylon, where it is very extensively cultivated. Much dispute has arisen between various authors as to the derivation of the common name of this spice. It has been known from a very eariy period, and formed one of the ingredients in the holy oil of anointing used by Moses 
in sanctifying the holy things of the Tabernacle:- "Take thou also unto thee principal spices, of pure myrrh five hundred shekels, and of sweet cinnamon half so much, even two hundred and fifty shekels, and of sweet calamus two hundred and fifty shekels, and of cassia five hundred shekels, after the shekel of the sanctuary, and of olive oil a hin." Exodus xxx. 23, 24. This passage will also bear us out in saying that in ancient times the term spice applied to many things not spices according to our definition of the term; for instance, the myrrh and sweet calamus, the former being a gum-resin, and the latter a species of grass, probably one of the Andropogons, many of which are highly fragrant.

Some authors give the Hebrew name Kinman as to the origin of the modern name; some attribute it to the Greek $\kappa \iota \nu \nu a ́ \mu \omega \mu о \nu$, first used by Herodotus, 430 years before Christ; but as the plant is a native of the Malay Islands and Ceylon, the name is probably either of Malayan or Cingalese origin, the former being Kaimanis, and the latter Cacyn-nama, or sweet-wood. Both as a spice and also as a medicine, cinnamon has been for ages in high esteem. The Arabians received it from India, and from them it was transmitted to the Hebrews, Greeks, and Romans. 
Although the cinnamon shrub is found growing wild in Java and Ceylon, the wild cinnamon is not considered of any value; the indigestible seeds are said to be carried from place to place by birds which feed upon the berries-a fact thus alluded to by Moore, the Anglo-oriental poet :-

"And mine is the gentle song that bears

From soul to soul the wishes of love, As a bird that wafts through genial airs The cinnamon-seed from grove to grove."

The same poet also gives an exquisite simile of the sweetness of the bark :-

"The dream of the injured patient mind,

That smiles at the wrongs of men,

Is found in the bruised and wounded rind

Of the cinnamon, sweetest then."

The shrub which produces the cinnamon belongs to the Laurel tribe, and, though not so compact as the common laurel (Cerasus Laurocerasus), resembles it very much; it is an evergreen, and the leaves are of a pale yellowish-green colour, deeply veined and ribbed; they possess the same flavour as the bark, in a less degree; they were formerly sold as a substitute for the spice, under the name of folia malabathri, as were also the leaves of other species called 
Laurus malabathrica, or Cinnamomum nitidum, and the $C$. Tamala. The common evergreen Laurel of the gardens does not belong to the same Natural Order as the cinnamons, and is only mentioned as resembling the spice-plant.

The cinnamon-bark of commerce is in the form of thin rolled sticks, or quills, as they are technically called, about three feet in length, and compact. In Ceylon, the bark-peelers are called Choliahs; they choose such branches or twigs as are three years old; from these they remove the bark by making two or more longitudinal incisions, according to the size of the branch; these cuts extend the whole length of the bark, which is then easily removed by inserting under it the point of the blade of the peeling-knife; the next day the epidermis or upper bark separates easily, and is then removed, with the middle or green bark; the portion left is the undermost or cinnamon bark, in which resides the beautiful flavour; this, as it dries, curls up, and forms the quills, and before they become quite hard and brittle, the smaller ones are inserted into the larger ones, until compact sticks are made, which are not so liable to breakage, and do not take up so much room in packing as single quills. When dried, the bark is of a very peculiar rich brownish-yellow, which has received the name of cinnamon-colour; it is very 
brittle, and the best is extremely thin, and fibrous in the longitudinal direction.

Cinnamon is usually imported in round bundles, tightly covered with gunny matting. The quantity imported in 1850 was 312 tons ; but in 'Poole's Statistics' it is stated that of this, 272 tons were re-exported, leaving only 40 tons for consumption in this country ; this however, in consequence of the extreme lightness of cinnamon-bark, is a large quantity.

Cassia, or Cassia-Lignea. - This spice is supposed to be yielded by the Cinnamomum Zeylanicum, the same plant as the true cinnamon, the difference probably arising either from the age of the shoots from which the bark is taken, or else from difference of climate and culture; it is coarser, more strongly flavoured, but to some persons more agreeable than cinnamon; to others it is disagreeable. It is cultivated to a very great extent in China, whence it is imported in chests similar to those in which tea is packed. The imports in 1850 were nearly 300 tons.

Cassia Buds.-This elegant spice is less known than it deserves to be; the buds are supposed to be yielded by the same variety of cinnamon as that from which the Cassialignea is derived; they are the immature flowers gathered 
and dried, and possess the cinnamon flavour in addition to a most agreeable sweetness. The flowers of the cinnamon are borne in loose terminal bunches or panicles; they are white in colour, and are succeeded by black berries about the the size of a sloe, the calyx remaining at the bottom; these calyces are often mixed with the unexpanded flowers for Cassia-buds. According to some authors, the buds of other species of cinnamon, and especially those of $C$. Loureiri, are also dried and sold as Cassia-buds.

There are several species of cinnamon which yield fragrant aromatic barks, but they do not often occur in commerce, and only in very small quantities; they are

The Culilawan Bark, produced by $C$. Culilawan, a native of Amboyna, often called Clove Bark, in consequence of its flavour resembling somewhat that of cloves. It must not be confounded with the Clove Bark of South America, which is not produced by any species of cinnamon. It is in rather thick flat pieces, of a brownish-red colour. Cinnamomum rubrum, C. Javanicum, C. Sintoc, and C. xanthoneuron, also yield barks similar to the Culilawan.

Clove Bark.-This bark is the produce of Dicypellium caryophyllatum. (Nat. Ord. Lauracea.)

A large tree, which, according to Martius, is the finest of 
94

POPULAR ECONOMIC BOTANY.

all the Laurel tribe found in the Brazils. Small parcels of Clove-bark are occasionally imported and sold for the purpose of mixing, when ground, with other spices; its colour is a clove-brown. It is much thicker than cinnamon, being about the sixteenth of an inch in thickness; it is in quills, one within another, usually two feet in length and an inch in diameter, each quill bound tightly round with thin pieces of split rattan-cane. A fine plant of this interesting species is now growing in the stove of the Liverpool Botanic Garden, raised by Mr. Shepherd the curator, from seeds received by him from Para.

Sassafras Nuts, or Pichurim Beans.-These are the product of another tree of the Natural Order Lauracea; they are the cotylectons of a species of Green-heart called Nectandra Puchury; the seeds are split in two, and the halves, or cotyledons, are about an inch and a half in length and half an inch in width, convex on the outside, and rather concave on the inner surface, at one end of which the mark of the embryo is slightly indented. They have been called Wild Nutmegs, which is very erroneous; they however have the flavour of that spice, added to that of Sassafras-wood. They are much in request with chocolate manufacturers for flavouring chocolate, as a substitute for the costly vanilla. 



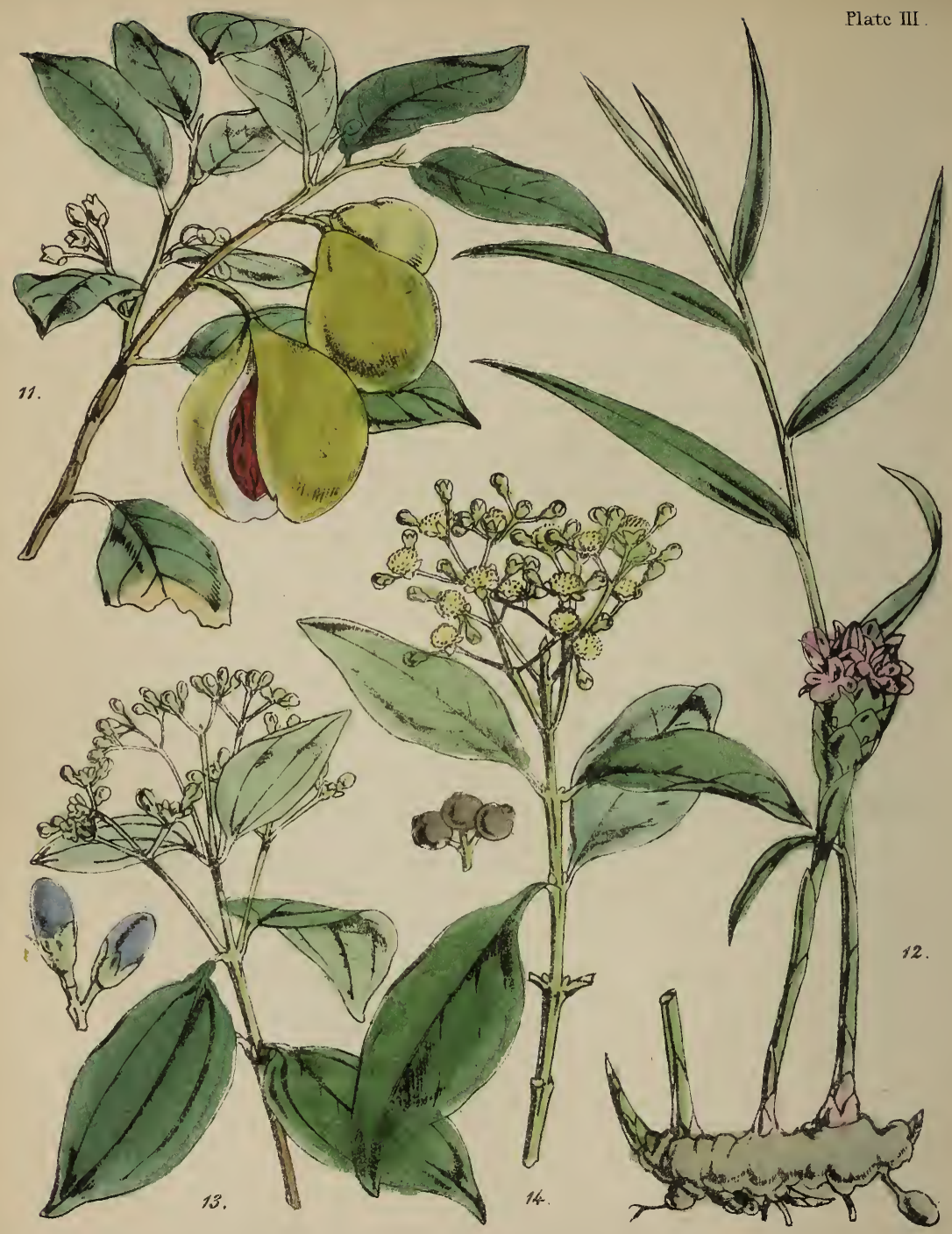

11. Nutrneg Plant, 12. Ginger Plant. 13 Cinnamon Plant. 14. Allspict Mlant. 
Their colour externally is a dark brown, internally cinnamon brown. They are not often imported, and cannot easily be met with, owing to the demand which always exists for them.

The Nutmeg. Myristica moschata. (Nat. Ord. Myristicacea.) (Plate III. fig. 11.)

This well-known spice is of comparatively modern introduction; the first mention of it is by Avicenna, a celebrated Arabian physician, about the middle of the eleventh century : both Nutmegs and Mace were used by him medicinally, and great virtues attributed to them.

The nutmeg-tree reaches twenty to twenty-five feet in height; it is finely formed, and strongly resembles our peartree in its general appearance, and also in its fruit, which is not unlike the round Burgundy pear. Belonging to the Linnæan Class Dicecia, its pistils and stamens are on different plants; the stamen-flowers are in small bunches of three or five, on short pedicels, the peduncle arising from the axils of the leaves; the pistil-flowers are sometimes solitary, that is, singly placed on a footstalk or peduncle. The fruit consists of the fleshy pericarp, which, when ripe, splits or dehisces into two halves, showing inside the nut or nutmeg enclosed in an arillus or stringy covering, which is the Mace. The external portion of the fruit is not used, except occasionally 
as a preserve. The arillus and the enclosed nut are both valuable spices.

For a long time the nutmeg culture was confined to its native habitat, the Molucca Islands, by the jealousy of the Dutch, whose possession of these islands gave them command over their produce; when however they were for a short time in possession of the English, during the great European war, the nutmeg and other spices were introduced to Penang and others of the Malay and Indian islands. The nutmegs we receive are chiefly from the island of Penang and from the Cape of Good Hope; those of the Cape are first imported there from various places.

There are several kinds of nutmegs, which are of inferior quality, and are the produce of different species of plants; they are occasionally imported for the purpose of mixing with or adulterating the true spice; they are-

The Shell Nutmeg, Long Nutmeg, or Wild Nutmeg of Sumatra and Madagascar, which is the fruit of Myristica Madagascariensis. - This nut is enclosed in a thin brittle shell, over which grows the arillus and pericarp. The shell is of dark brown colour, looking as if varnished; it is an inch and a half in length, and not much thicker than the common nutmeg. Its value is very inferior. 
MACE.

The Wild Nutmeg of Brazil (Myristica Otoba) is another shell-nutmeg; the shell is black, thin, and deeply indented with marks of the arillus. It occurs very rarely.

The False Nutmeg of the Indian Archipelago is much used as a substitute; it is the fruit of Myristica spuria.

The fruits of several Lauraceous plants also bear the name of Wild Nutmegs, as-the Ackawai Nutmeg, the fruit of Acrodiclidium Camara; the Clove Nutmegs of Madagascar, the fruit of Agathophyllum aromaticum; and the Brazilian Nutmegs, the fruit of the Cryptocarya moschata,-all of the Natural Order Lauracea.

Used moderately, the nutmeg is a most agreeable spice; its fine flavour depending upon a large quantity of two sorts of oil, one a colourless essential oil, and the other a yellow vegetable fat called $\mathrm{Oil}$ of Mace. In large quantities the nutmeg is injurious, acting as a narcotic. The quantity imported is annually about 120 tons, of which nearly one-half are re-exported.

Mace, the arillus of the true nutmeg, is also a valuable spice; it is a flat branching membrane, not unlike the envelope of a filbert, but of a bright cinnamon-yellow colour; the flavour resembles that of the fixed oil of nutmegs. Quantity imported in 1851, according to 'Poole's Statistics,' 
34 tons; re-exported, 20 tons ; used for home consumption, only 9 tons,-nearly all from Penang.

Cloves are the unexpanded flower-buds of the Clove-tree. Caryophyllus aromaticus. (Nat. Ord. Myrtacea.) (Plate II. fig. 10.)

The Clove does not appear to have been long known in Europe: Sir J. E. Smith supposes it to be the Carunfel of Serapion, and the Carunfel bellum of Avicenna, two Arabian physicians of the eleventh century; but it was previously mentioned by Paulus Egineta, a Greek physician in the seventh century, under the name of $\kappa a \rho v o ́ \phi v \lambda \lambda o \nu$. It is a native of the Molucca Islands, and for a long time constituted an important trade with Amboyna, the chief of the Moluccas. In this island alone, the Dutch, who were masters of the whole group, permitted the clove to be cultivated, carefully extirpating the plant from all the other islands; and even here they only allowed a limited number of trees to be cultivated, lest the price should fall too low. This narrow policy produced its natural effect: it stimulated the desire of other nations to possess so valuable a spice, and eventually in 1770 the French by some means obtained and introduced it to the Isle of Bourbon, where it flourished; thence it was carried to Cayenne and the West Indies; it is now 
CLOVES.

grown almost wherever the climate is suitable. Its culture is extremely easy, requiring no more attention than a peartree, which it very much resembles; the trunk rises from fifteen to twenty feet, branching out horizontally about four or five feet from the ground.

The clove-tree is remarkably handsome, being evergreen, and the beautiful pink buds and flowers are produced in great profusion, in short terminal panicles of from nine to fifteen or eighteen on each bunch; the pedicels divide into threes, and are articulated, or jointed; this very much facilitates the falling off of the bud when the gatherers beat the trees with wands or reeds. They are either procured in this way or gathered by hand, after which they are dried in the sun or by fire; this latter method is only employed in unfavourable seasons, as it injures the flavour.

The average produce of a clove-tree in Amboyna is two or two and a half pounds per annum; the first tree however which was planted by the French in the Mauritius was seen by M. Bory de St. Vincent in 1769 covered with cloves, who ascertained that it occasionally had produced the enormous quantity of $125 \mathrm{lbs}$. As it requires 5000 cloves to weigh one pound, there must have been upwards of 625,000 flowers on this fine tree, which was forty feet in height, 
and of great circumference. From the slight resemblance this spice bears to a nail, the corolla and sepals of the calyx forming the head, and the long thin tapering ovarium the spike, the Dutch named it Naghel; the Spaniards Clavo; the Italians Chiodo; and the French Clou; from this last we have derived our name Clove.

Besides being one of the most valuable spices, the clove is very useful in medicine, its virtues residing in the aromatic stimulant properties of its essential oil. Clove-stalks, which are said to be stronger than the cloves themselves, are occasionally imported for the distillation of the oil ; and sometimes, though very rarely, the preserved fruit reaches this country. We receive cloves from the East and West Indies, from the Mauritius, indirectly from Holland, and in 1850 a small parcel was received from Brazil; it was not however ascertained whether they were there cultivated. The quantity of cloves imported in 1851 was not less than 334 tons, of which only 70 tons were re-exported to the colonies and elsewhere.

Allspice, Pimento, or Jamaica Pepper, is the unripe fruit of Engenia Pimento dried in the sun. (Nat. Ord. Myrtacee.) (Plate III. fig. 14.)

It is called.Allspice from the fact that its flavour resembles 
that of a mixture of cloves, cinnamon, and nutmeg. It agrees very closely in appearance with a spice mentioned by Pliny under the name of garyophyllon; but it could not have been known to the Roman naturalist, as it is a native of the West Indies, which of course were then unknown to the Old World.

The Pimento is much cultivated in the West Indies, especially in Jamaica, where it is formed into plantations, having broad walks between the rows of trees, called Pimentowalks. The berries are gathered when nearly ripe, at which time the essential oil, upon which they depend for their aromatic flavour and pungency, is most abundant; they are spread upon sheets and wooden platforms purposely erected, and are frequently turned and winnowed whilst drying in the sun. When dried, the Allspice is about twice the size of a pepper-corn, and consists of a thin rough soft shell, perfectly round, and bearing at the top the marks of the calyx, and occasionally, but rarely, the short pedicel at its base; it encloses two seeds, which are closely packed within the shell. The flavour resides chiefly in the shell; the colour is a fine clove-brown. The consumption of allspice is very great, it being a cheap and very useful spice : 22,000 bags, weighing 1022 tons, were imported into London 
and Liverpool in 1850, and about one-fifth of that quantity were re-exported.

Black Pepper. - The dried ripe berries of Piper nigrum. (Nat. Ord. Piperacece.) (Plate II. fig. 9.)

This spice was known to the ancients; it was used by the Greeks and Romans, both medicinally and as a condiment; they received it from India, its native country.

The Black Pepper plant has a climbing habit; the jointed stems occasionally grow as much as twelve feet in length; the leaves are thick, fleshy, and elliptical, broad at the base and pointed at the apex; the flowers form compact spikes all round the terminations of the short bunches; they are small and inconspicuous, and are succeeded by a compact cluster of round berries, which are at first green, but ripen to a bright-red colour. They are gathered as soon as they begin to redden, for if allowed to ripen fully, they lose their pungency and fall off; in drying they become wrinkled and black. The pepper plant is strictly tropical in its character, but grows freely wherever the climate is suitable; hence its culture has been greatly extended, and it is now found as a regular crop in the East and West Indies, in Borneo, Sumatra, the Molucca Islands, the Malay Peninsula, Siam, Malabar, and other places. 
PEPPER.

White Pepper is the same as black pepper, except that the black wrinkled covering of the seed is removed. To accomplish this, the dried berries are first soaked in water, and when the outer layer is softened they are rubbed until it is removed. The internal seed is of a whitish-grey colour, and when dried constitutes white pepper. It often undergoes a process of bleaching by chlorine, which improves the colour, but deteriorates the quality.

The quantity of pepper imported is immense: the returns of the Board of Trade give 3608 tons for 1851 ; but from this quantity we must deduct about one-sixteenth for Cayenne Pepper and Long Pepper, which are always returned with the above as pepper.

Long Pepper is the unripe spadix, or fruit-spike, of the Piper longum. (Nat. Ord. Piperacea.) (Plate II. fig. 8.)

This plant is shrubby and climbing, bearing its flowers at the ends of short branches, in spikes or spadices, somewhat resembling our common Rib-grass or Plantain-weed, well known as a favourite food for canaries. The seeds are packed so closely on the peduncle as to appear one compact mass; they are gathered whilst still green, and dried in the sun; they have a white mealy appearance when dried.

The Long Pepper is a native of the Circar Mountains of 
104 POPULAR ECONOMIC BOTANY.

India, where it grows amongst the bushes; it is however extensively cultivated in many parts of India, especially Bengal. The use of long pepper in this country is rather limited, and as the returns are always included in those of black pepper, the consumption cannot be exactly ascertained.

GINGER.-The dried underground stem, or rhizome, of the elegant reed-like tropical plant, Zingiber officinale. (Nat. Ord. Zingiberacece) (Plate III. fig. 12.)

Some doubt exists as to the native country of this spice, but it is generally supposed to belong to the warmer parts of Asia. It has long been known and esteemed. Dioscorides and Pliny both mentioned it; the former under the name of $\zeta$ $\gamma \gamma(\beta \epsilon \rho \iota$, and the latter Zingiberi. By modern botanists it was formerly called Amomum Zingiber ; but Mr. Roscoe,whose splendid work on the 'Scitamineæ,' a Natural Order to which the Ginger was formerly referred, has entitled him to as high a rank amongst botanists as his miscellaneous works have elevated him amongst writers of belles lettres, -removed the ginger-plant from the genus Amomum, and raised it to a distinct genus, to which he judiciously gave the Plinian name Zingiber.

The ginger of commerce is in the form of dry wrinkled rhizomes, called races, about two or three inches in length, 
branching, flat, and of a whitish colour; their breadth about three parts of an inch. There are two varieties, which depend upon the mode employed in preparing them. When the root-stalk or rhizome is abont a year old, it is dug up, scalded with boiling water, and then dried; so prepared, it is called black ginger. If, in addition to this process, it is also carefully scraped, so as to remove the wrinkled epidermis, it then receives the name of white ginger, which often in this country undergoes the still further process of bleaching with chloride of lime.

Although it is fully understood that the mere mode of preparation leads to the above distinction into two sorts, it is thought that there also exist two sorts of the gingerplant, one yielding darker-coloured races than the other. Thus the East Indian Ginger, though unscraped and unbleached, is called White Ginger, because its wrinkled epidermis is as light-coloured as the African ginger is when carefully scraped. This opinion is supported by the testimony of Dr. Wright and other botanists of eminence.

The varieties recognized in commerce areWhite varieties:-Jamaica White Ginger, Barbadoes Ginger, African Ginger, East Indian Ginger, and Tellicherry Ginger. 
Black varieties:-Jamaica Black Ginger and Malabar Dark Ginger.

The term black ginger is very erroneous, as the colour of the darkest is only a dirty stone-colour.

The newly-formed races which are put forward in spring are often cut off and preserved in syrup, much of which is imported in jars under the name of preserved ginger, and, as an agreeable addition to the dessert, is much esteemed. The quantity of ginger imported from all places in 1850 was about 500 tons.

Capsicum, or Chilli.-The fruit or berry of Capsicum annuum. (Nat. Ord. Solanacea.)

The variety of Capsicum usually found in commerce is in large withered dark-red pods, always broken, and the pulp dried up. It comes packed in bales of about $2 \frac{1}{2}$ cwt. from the East Indies, where it is a native. The principal use of this is to make Cayenne pepper.

But besides this, we receive several other species and varieties, usually as pickles in vinegar. Thus-The Cherry Pepper, or Round Chilli (Capsicum cerasiforme); the Bell Pepper (C. grossum); the Long Capsicum (C. longum); the Heart-shaped Capsicum (C. cordiforme); the Yellow Capsicum (C. luteum); the Bird Pepper (C. baccatum). These 
are rarely received, except in a pickled state. They are much valued as a digestive condiment, especially by dyspeptic persons ; and are often raised both for ornament and use in this country. About 80 to 100 tons are sometimes imported in one year; the imports are however very irregular.

Cardamoms. Elettaria Cardamomum. (Nat. Ord. Zingiberacece.) (Plate XVI. fig. 81.)

The seeds of several plants pass in the druggists' shops under the general name of Cardamoms, but those of the Elettaria above mentioned are the true officinal, small, or Malabar Cardamoms. The uses of this seed are strictly medicinal with us, and are usually described as Materia Medica; their use in medicine however is only that of a warm aromatic stimulant spice; and in India they are much used as a favourite condiment for various kinds of food, forming, according to Mr. White, an important accessory to the luxuries of the inhabitants of India and other parts of Asia.

The cardamom is a three-sided seed-pod, pointed at each end, and about half an inch in length, of a pale straw-colour, having the surface roughened with five longitudinal furrows, and a deeper one in the middle of each side; the diameter is about half the length, and the seeds are 
about the size of mustard-seeds, with a rough dark-brown exterior, and rather irregular shape.

Besides the officinal cardamom, the following occasionally find their way into the market, but are of inferior value:

The Ceylon, or Wild Cardamom (Elettaria major) is longer, often with the remains of the persistent calyx at one end, and the stalk at the other. It is rarely imported.

The Java Cardamom (Amomum maximum), the produce of another genus of the same Natural Order.-This is almost globular in shape, and nearly as large as a moderatesized gooseberry. They are cultivated in various parts of India, but are not much esteemed in Europe.

The Round or Cluster Cardamom (Amomum Cardamomum.) -A native of Sumatra, Java, and other Indian islands; it is nearly globular; they are of rare occurrence. The quantity of all kinds imported is about 25 tons per annum.

Grains of Paradise, or Malaguetta Pepper.-Supposed by Dr. Pereira to be the seeds of two distinct species of plants, the Amomum Grana-paradisi of Sir J. E. Smith, and the $A$. Meleguetta, Roscoe ; and probably of others.

They are always imported from the coast of Guinea. The seeds, which are freed from the husk, are longer and 
rounder than the seeds of the true cardamom: they are of a glossy dark-brown colour, and a warm pungent taste, resembling pepper, with a slight flavour of camphor. The natives of Africa use this seed as a spice, and with them it is in great esteem. With us it is used to give a fictitious strength to spirits and beer, but principally the former, being extensively used with capsicum and juniper-berries to give a hot strong flavour to London gin; it is also used in some veterinary medicines. The former use is illegal, but it nevertheless prevails to a great extent. The quantity imported is about 18 tons annually.

VArilld.-The seed-pods of Tanilla aromatica. (Nat. Ord. Orchidacea.)

The Vanilla, or Tanile, as it is sometimes called, is in the form of long thin pods, from nine to twelve inches in length, but not exceeding a quarter of an inch in thickness, filled throughout their entire length with very minute black oily seeds, having the appearance of a black paste; the outside of the pod is slightly wrinkled in longitudinal furrows, and is of a shining dark-brown colour; altogether it resembles a thin brown stick rather than the seed-vessel of a plant. Both the flarour and smell of vanilla is remarkably delicate and agreeable, and is peculiar to the Orchideous plants. 
As a spice, it is used for flavouring ices, custards, and particularly chocolate, for which purpose the Spaniards employ it extensively; but its high price prevents its being used to any great extent in this country. An inferior kind, with shorter and thicker pods, is occasionally met with; it is probably the pods of $V$. sylvestris and $V$. sativa. The quantity imported is small, amounting only to about 5 or 6 cwt. per annum.

Canella-Bark.-The inner bark of Canella alba. (Nat. Ord. Canellacea, Von Martius.)

This is another of the articles usually classed as Materia Medica, but which has as fair a title to be considered a spice as cinnamon or clove-barks. It is the produce of a tree growing fifty feet in height, and is separated from the outer bark by beating. The Negroes of the West Indies and America, where it is a native, use it as a spice. Large quantities are produced and exported from the Bahamas, where it is termed Wild Cinnamon and White-wood bark.

Canella-bark is in thick quills, or portions of quills; it is of a light drab colour, about one-sixteenth of an inch in thickness, having a slight odour of cloves; the taste is that of a mixture of cloves, cinnamon, and pepper. In this country it is only used as a medicine. It has often been 
confounded with a medicinal bark called Winter's Bark, or Drimys Winteri, but it is quite distinct from it. The imports are very small and occur irregularly.

MUstard.-The seeds of Sinapis nigra, often mixed with Sinapis alba. (Nat. Ord. Cruciferce.)

The small round seeds of these two species of Sinapis are crushed between rollers, and then pounded in mortars; it is then sifted through a fine sieve, and yields a coarse flour of mustard, which is again sifted through a finer sieve, and the product is the flour of mustard in common use. It is often adulterated with the seeds of the Charlock or Wild Mustard (Sinapis arvensis), and wheaten flour is also added for the same purpose. The outer skin of the seeds, separated by the siftings, forms a coarse powder, which, under the initials P.D. (i.e. pepper-dust), is sold for adulterating pepper, and is also used for expressing the fixed Oil of Mustard. Mustard-seed is largely imported from the East Indies for the expression of oil ; and white mustard-seed is imported from Northern Germany in small quantities, for grinding with the black mustard-seed grown in this country.

There are a few seeds which, from their pungent aromatic 
flavour, are used as condiments, and may very properly be classed with the spices; the principal are these:-

Caraway.-The seed of Carum Carui. (Nat. Ord. Umbelliferce, Jussieu ; Apiacea, Lindley.)

This plant derives its name from Caria, its native country; it received this appellation from the Roman natural historian Pliny; Dioscorides called it кápos, evidently for the same reason. Botanically speaking, it is properly a fruit, the brown outer covering being the shell, or seed-vessel; and, two of these being always joined together when on the plant, they are termed mericarps, or half-fruits.

The taste of the Caraway being warm, aromatic, and agreeable, and its production cheap, it. forms a valuable spice for the humbler classes, and is much used in confectionery. It grows wild in many parts of England, having become naturalized; in some parts it is much cultivated, especially in Essex; we however receive large quantities both from Holland and Germany.

Besides being used to flavour various kinds of food, the essential oil of these seeds is used in medicine, and the seeds themselves are enveloped in sugar, and form the confection called "caraway comfits," so well known to children. The manner in which these are manufactured is not gene- 
rally known, and perhaps few have taken the trouble to reflect how such small seeds are so completely and regularly invested with their coating of white sugar. As the process is as simple as it is curious, we will describe it:- In the first place a large copper pan, similar in shape to the pans of the small scales used in shops, and capable of holding about half a bushel, is suspended by three cords over a charcoal fire, at such a distance as to be slightly heated; into this, about a pint of seeds are put, with a very small quantity of fine syrup made from refined sugar; the manipulator keeps the pan moving quickly round and round, by which means the seeds are all slightly coated with the syrup, and prevented sticking together, whilst the heat dries them completely; this operation is repeated from time to time, increasing the quantity of syrup as they get larger, until the proper quantity is applied. The whole art of the operator consists in patiently and actively conducting the process, so that the comfits become thoroughly dried each time before more syrup is added, and by the regular motion their sticking together is prevented.

Coriander.-The fruit of Coriandrum sativum, another of the Umbelliferce.

These seeds are used in a similar manner to those of the 
caraway, except that they are very rarely distilled for their essential oil. The Coriander has an aromatic sweet taste, with very little pungency; it also is a fruit (mericarp), though commonly designated a seed ; it is, like the caraway, an aunual plant. Its native country is the South of Europe, some writers say Italy; it is however capable of enduring a very wide geographical distribution, for it grows abundantly in India, and bears the climate of Britain equally well; indeed, it is sometimes found growing wild, and bearing fruit, from seeds accidentally scattered. Its history is much more ancient than that of the last-mentioned seed. The food which fell from heaven to feed the Israelites in the desert is thus described in Exodus xiv. 31: "And the house of Israel called the name thereof Manna: and it was like coriander-seed, white; and the taste of it was like wafers made with honey." It was also known to most of the writers of antiquity, by many of whom it was believed to possess great medicinal virtues; its Greek name was кópıov,

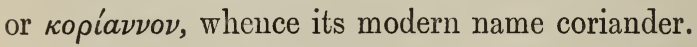

The whole plant, when growing, has a most disagreeable odour, and grows about two feet in height. The flowers are white and small, like most of the parsley tribe, and the seeds, growing in pairs, are round, except a slight flatness 
on the sides by which they adhere together; they are about twice the size of a mustard-seed, and are finely ribbed from the base to the apex. It is cultivated in many parts of England, particularly about Ipswich and in Essex. About 10 to 15 tons are also imported annually from Germany. Anise, or ANIsEed. - The fruit of another Umbellifer, Pimpinella Anisum.

Also of ancient reputation, deriving its familiar name

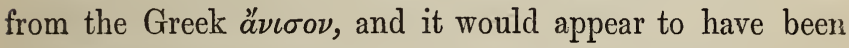
cultivated by the Hebrews, for we read in Matthew xxiii. 23, "Woe unto you, Scribes and Pharisees, hypocrites! for ye pay tithe of mint and anise and cummin, and have omitted the weightier matters of the law." Some writers imagine the anise here mentioned to have been the common Dill (Anethum graveolens), but apparently without reason, as the plant is a native of the Greek Islands and of Egypt, whence the Israelites derived many of their economic plants. It is used chiefly for flavouring liqueurs and various'articles of confectionery; its Essential Oil is also extensively used. Aniseed is very much like the finer kinds of parsley-seed in size and shape. It is largely cultivated in Malta, Spain, Germany, and in the East Indies, where it is called Aneesoon. But the term aniseed is applied in India to another seed 
having similar properties, but produced by a very dissimilar plant, the Illicium anisatum, or Star-Anise. The principal imports are from Alicant and Hamburg, and amount to about 70 tons annually.

Cumin.-Another fruit of the same Order, produced by Cuminum Cyminum. Its name is also derived from the Greeks, who call it $\kappa \dot{u} \mu \iota \nu o \nu$. It was well known also to the ancient Jews, for, besides the mention of it in the passage above quoted, we also find it alluded to much earlier, by the prophet Isaiah, xxviii. 27: "For the fitches are not threshed with a threshing instrument, neither is a cart-wheel turned about upon the cummin; but the fitches are beaten out with a staff, and the cummin with a rod." The translators have spelled the word rather differently, but there is no doubt the common cumin is the plant mentioned.

The cumin-seeds are somewhat like the caraway, but nearly twice as large. The flavour is to most persons disagreeable; but our Hebrew countrymen consume considerable quantities in their cookery. The other uses of this article are chiefly medicinal, especially in veterinary pharmacy. It is a native of Egypt and other parts of Africa, and is extensively cultivated in the South of Europe, and in India, where it is called Kumoon suffed. Our imports are princi- 
pally from Sicily, and only amount to three or four tons per annum.

We must here mention another umbelliferous plant which is used as a condiment; the mode of using it however differing very materially from those above mentioned, the green stems and the dried roots being the parts employed :-

The ANgelica plant (Archangelica officinalis), a comparatively modern addition to our aromatic condiments. It is a native of Northern Europe, but is cultivated as far south as Spain and Italy. The green stems are cut into short pieces, and preserved by candying with sugar; thus prepared, they are used in confectionery, and have a very agreeable pungent warm taste, and are esteemed useful in assisting indigestion. Candied Angelica is however less used at our desserts than it deserves to be. Large quantities, amounting to 30 or 40 tons, of the dried root are annually imported from Hamburg, and are chiefly used by distillers and rectifiers of gin in giving a spurious strength to that and other spirits.

TURMERIC is also used as a spice, particularly in curries ; but as dyeing is its principal use, it will be described as a dye-stuff. 
$\therefore \quad$ CHAPTER VI.

MISCELLANEOUS ARTICLES.

UNDER this head we must place a few articles which are of great importance, but they cannot be arranged under any of the previous chapters. They are usually described under the name of groceries; but as this term is so indefinite, we prefer the above title for the group now under consideration. The first we shall describe is

TEA.-This well-known vegetable product consists of the dried leaves of two or three species of Thea, as T. Bohea (Plate I. fig. 1), T. viridis, and T. Assamica (?). (Nat. Ord. Ternströmiacea.)

It was long supposed that green tea was the produce of Thea viridis, and black tea of T. Bohea. Mr. Robert Fortune however ascertained that both kinds were usually made from 
T. viridis, and the Chinese tea-makers employed by the East India Company in Assam made both black and green teas from each of the species; the essential difference consisting solely in the different methods of preparation.

Black tea is prepared by throwing the leaves into a heap immediately after they are gathered; this induces a slight degree of fermentation, or spontaneous heating, similar to that which occurs when hay is stacked without being perfectly dry. The fermentive process renders the leaves flaccid, and changes their colour, darkening it considerably; so that when it is brought to the twisters it is nearly black. In this state small bowls of the leaves are brought in and set before the operators, who, by a dexterous action of the thumb and forefinger, twist every leaf in the bowl, the contents of which are then taken to the drying-room, where they are put into a cylinder of basket-work, which is turned over a small charcoal fire; here the leaves are dried for one hour, receiving, during this period, one or two stirrings, by which the tea is thoroughly exposed to the drying influence of the fire; then they are again returned to the bowls, and are once more rubbed and twisted, after which they are shaken in a hair sieve, which separates the fine dust from the leaves; they are then again returned to the wicker cy- 
linder, and over a much slower fire undergo the final drying, by which they become black and crisp. This process is sometimes slightly varied according to circumstances.

The principal varieties of Black Tea are Boliea ( Vo-he in Chinese); Congou (Cong-fou); Souchong (Se-ou-chong); Pekoe (Pe-kow); and Caper, which is in little hard rounded masses, consisting of the very fine dust of the other varieties, made up with gum : it is a high.priced tea, though really not of superior quality.

Green Tea does not undergo the process of fermentation or heating; on the contrary, the leaves are at once submitted to a high temperature in pans, called kuos, placed over charcoal fires; they are taken off from time to time, and the twisters manipulate the leaves with their fingers, rolling them up, whilst still flaccid with the contained moisture. When over the fire they are constantly and briskly stirred, and the rising steam is blown or fanned away.

The principal varieties of Green Tea are Hyson Tea (Te-chune, or first crop), Hyson Skin, Twankay, Imperial, and Gunpowder.

Some of the teas, both black and green, have a fine cowslip odour, which is produced by mixing the small dried flowers of the sweet-scented olive (Olea fragrans). 
Owing to the high duty and high price of tea, it is an article which is much sophisticated, not only by the dealers in this country, who adulterate with the leaves of various indigenous trees, and the exhausted tea-leaves re-dried, but also by the Chinese themselves.

Latterly large quantities of a spurious article have found their way into this country under the name of Lie-tea, given to it by the Chinese manufacturers. It is used solely for the purpose of adulterating other teas, and at first sight has the appearance of fine gunpowder; it is composed of the dust and sweepings of the tea-warehouses; this dust is mixed with chrome-yellow and Prussian-blue, in very fine powder, and in such proportions as to give the peculiar light-green tea colour to this compound. A liquid, formed by boiling the husks of rice in water until it has the consistency of thin gruel, is then sprinkled in whilst the mass of powder is at the same time briskly stirred with rods, which causes it to granulate, and produces a very close imitation of green tea. Mr. Warrington has stated that the colouring matter of lie-tea is a mixture of Prussian-blue and turmeric, with a large proportion of fibrous gypsum; and that the black lie-tea is covered with earthy plumbago or black-lead, having only a slight lustre. The author has 
inspected very large quantities of the green sorts, and cannot agree with Mr. Warrington that turmeric is the yellow colouring matter employed, both the smell and taste of that drug being so powerful and peculiar that it could not fail to be detected, and by its strong flavour would spoil the whole quantity ; besides, there is good reason for believing that mineral yellow colours are exported from this country for the purposes of this ingenious adulteration. A very slight magnifying power applied to the spurious tea will show its heterogeneous composition.

Formerly, all the tea imported into Europe was exported from China; its culture was however some time since attempted in Java, Penang, and Rio de Janeiro. After many failures it has fully succeeded, and large quantities are now raised in the two former places, and its cultivation is extending in South America under the Brazilian government.

In 1807 Dr. J. Forbes Royle called the attention of the Indian Government to the great probability of the Chinese plant succeeding on the base of the Himalayan mountains, where a species of tea had already been discovered, which was indigenous to the warm moist valleys of those mountains. He pointed out the similarity of the temperature, and other circumstances of that locality, to those in which 
the tea was known to be found naturally in the north of China. The trial was made with successful results; the Assam Tea Company was formed, and with very great care large quantities of Chinese seed were procured, sown, and successfully reared, so that now the Company have upwards of a thousand acres under cultivation in the favourable situations occurring in the district stretching from Kemaon to the hill tracts acquired from the Seiks. The plants grown are chiefly those raised from Chinese seed; the remainder are the indigenous plants, supposed to be a distinct species, which has received the name of Thea Assamica. It is a much more vigorous-growing plant than that of China, and has much larger leaves. Chinese tea-curers have been induced to settle in Assam, and from each of these plants both black and green teas are made by the Chinamen. The tea of Assam is of a superior quality, and fetches a high price in the market ; being a very strong kind, it answers well for mixing with the low sorts of China tea, to bring up their quality, and for this purpose it is chiefly used. Several large shipments have now been received from India.

Tea is imported in chests of a peculiar manufacture, always lined with thin sheet-lead, and frequently with a peculiar kind of paper, of Chinese manufacture, made from the 
liber, or under bark, of the Broussonetia papyrifera; it is of a silky texture, straw colour, and is made without size. The total quantity of tea imported into the United Kingdom in 1851 was 52,640,000 lbs., of the gross value (duty paid) of $£ 9,675,000$ (Poole's Statistics). The quantity re-exported is considerable, and is said to be nearly 2000 tons.

Although never imported, except as a curiosity, and certainly never used in England, we must not omit to mention the curious "Brick Tea" of Tibet. It is in blocks shaped like bricks, or in coarse fragments of such blocks; the blocks are usually wrapped in paper or sewn up in sheepskins. It is even more objectionable than the "lie tea," being made of the refuse leaves and sweepings of the tea warehouses mixed with bullocks' blood, then made damp and pressed into moulds and dried by fire-heat.

Paraguay Tea. - The broken leaves and smaller twigs of the Paraguay holly, Ilex Paraguayensis, and probably also those of I. Gongonha and I. theezans. (Nat. Ord. Aquifoliacece.)

This production of Brazil, and various other parts of South America, is extensively used in those countries as a substitute for tea, which it strongly resembles in smell and in taste. It has also been proved that theine, the active 
principle of the true tea, exists also in these species of holly. Small parcels of it are frequently imported into England, generally under the Brazilian name Maté, or Yerba, and Yerba de Palos. The Maté is of a yellowish-green colour, strongly smelling of tea; the leafy portion is much broken up, being almost a coarse dust; small pieces of the wood are plentifully mixed with it, often in pieces an inch and a half to two inches in length, and as thick as a quill. That which reaches this country is not for commercial purposes, but comes as presents.

Several other plants afford substitutes for tea in different countries; thus-

In North America, the leaves of a pretty little evergreen bush, often seen in our shrubberies, called Prinos glabra (Nat. Ord. Aquifoliacea) is used in the Northern States. It is sometimes called Apalachian Tea.

In New Jersey, one of the United States, the leaves of Ceanothus Americanus (Nat. Ord. Rhamnacea) are dried and used under the name of New Jersey Tea. This tea-plant is not an evergreen, like the preceding ones, but forms a handsome bush, with elegant clustcrs of light-blue flowers.

In China the poorer classes use the leaves of another plant of the same Natural Order-Sageretia theezans. 
In Bencoleen the Malays use the leaves of a plant belonging to the Natural Order Myrtacea, named Glaphyria nitida, which they call " Kayo Umur Panjang," or the Tree of Long Life.

In Japan leaves of Hydrangea Thunbergii (Nat. Ord. Hydrangeacee) are dried and used as tea, which is so highly valued that the Japanese call it Ama-tsjâ, or the Tea of Heaven.

In Austria, a substitute for tea is sold under the name "Brazilian Tea," and the genuine article is often much adulterated with the same material; it consists of the prepared leaves of Stachytarpheta Jamaicensis (Nat. Ord. Verbenacea). Another plant of this Natural Order is highly esteemed by the Brazilians as a tea-plant; they style it Capitaô do Matto; it is the Lantanapseudo-thea, and, from its agreeable aromatic qualities, is perhaps the best of all the substitutes above mentioned.

The leaves of Ledum latifolium, called by the natives Wischecumpuoware and Wiserpukki, are used in North America under the name of Labrador Tea; and the "Mountain Tea" of the same country is the dried leaves of the beautiful little partridge-berry (Gaultheria procumbens); both these plants belong to the Natural Order Ericacece. 
The "Mexican tea" of the United States, less commonly used, is the Chenopodium ambrosioides (Chenopodiacea); and the "Oswego tea" is the Monarda Kalmiana (Nat. Ord. Latiata) of North America.

In some parts of India the poorer natives use a species of Basil, Ocymum album (Labiata), under the name of Toolsie Tea.

The inhabitants of Chili use the leaves of Psoralea glandulosa (Nat. Ord. Leguminosa), which is also called Paraguay Tea, but is wholly unlike the Maté; and those of Myrtus ugni (Myrtacee).

In Central America the dried flowers of Capraria bifolia (Nat. Ord. Scrophulariacea) are used as tea, and so also are the dried leaves of Alstonia theaformis (Styracacea).

In New Holland the dried leaves of Leptospermum scoparium (Myrtacea) serve the same purpose.

In many parts of France the cultivation of Micromeria Thea-Sinensis (Nat. Ord. Labiate) is carried on for the purpose of serving as a substitute for tea.

There are doubtless many other plants used in the same manner, but the references to all of them are so scattered that much difficulty has been experienced in collecting the above list, which it is hoped will prove of interest to the 
reader ; besides this, many more are employed in the sophistication of the true tea, amongst which may be mentioned the leaves of the Black-thorn (Prunus spinosa) and those of the Hawthorn (Cratagus Oxyacantha).

It will be seen from what we have said of tea, its imitations and adulterations, that the injurious habit of drinking warm relaxing fluids has become almost universal. Its introduction into Europe is comparatively recent, having been first brought in by the Dutch East India Company. The first sample reached England in 1666, and sold at the high price of sixty shillings per pound, a price which is still realized in China for the finest qualities, which however rarely reach Europe. Examples of these high-priced teas were shown at the Great Industrial Exhibition. The use of the Paraguay tea is of ancient origin, and not in imitation of our use of the Chinese plant; it was found general amongst the natives when the Portuguese conquered Brazil, and has become a fashionable beverage amongst the European settlers all over the South American continent.

It must be observed that the value of these preparations for dietetic purposes depends, not upon their agreeable taste or nutritive qualities, but upon some stimulant property, probably analogous in many of them. Of all the 
COFFEE.

species above mentioned, the Brazilian Maté or Yerba is the most powerfully stimulant, producing a slight and agreeable intoxication, which when indulged in to excess leads to delirium tremens.

The next article in importance to Tea is

Coffee. - The dried seeds from the berries of Coffea Arabica. (Nat. Ord. Cinchonacece.) (Plate I. fig. 2.)

Coffee, the use of which is now almost universal, was introduced into England in 1652, fourteen years earlier than the introduction of tea. The following historical account of this article is from ' Woodville's Medical Botany,' a most admirable work:- "It was unknown to the ancient Greeks and Romans; the generally received opinion is, that the use. of its infusion as a drink originated in Ethiopia. But the practice of drinking it in Arabia was introduced from Persia by the Mufti of Aden, in the fifteenth century. In 1554 its use first began at Constantinople, from whence it was gradually adopted in the western parts of Europe. At Marseilles it was begun in 1644. At Paris it was nearly unknown till the arrival of the Turkish ambassador, Soliman Aga, in 1669. In 1672 the first coffee-house was established in Paris by an Armenian named Pascal, but, meeting with little encouragement, he went to London, where the 
beverage had been previously introduced in the year 1652, when Mr. Edwards, a Turkey merchant, brought from that country a Greek servant, named Pasqua, who understood the method of preparing coffee, and first sold it in London in a house which he kept for that purpose in George Yard, Lombard street."

There are few shrubs more elegantly beautiful than the Arabian Coffee. It rises from fifteen to twenty feet in height, with slender branches covered with fine light-green, smooth, shining, oblong-ovate and acuminate leaves; the branches are rather inclined downwards, giving the whole shrub a handsome pyramidal figure; the leaves are oppositely placed along the branches, and the flowers appear in the axils of the leaves, either one or more in each axil; the flowers are white, and not unlike those of the common jessamine; but the five segments of the tubular corolla are thinner and longer. Usually not more than one berry is borne in each axil, at the end of a very short peduncle, or stalk, so that the berries, like the leaves, appear in pairs : at first they are green, and rather smaller than a cherry; they acquire a reddish-brown as they ripen, and each berry contains two seeds, the enveloping pericarp being rather thick and fleshy, and becoming entirely dry as they become perfectly ripe; in 
COFFEE.

this state, under the name of "Coffee in the husk," it is occasionally imported.

When freed from the husk, the coffee-seeds, or berries, as they are commonly called, are hard and horny, somewhat resembling the texture of parchment; in the fresh samples from the West Indies they are of a pale-green colour, but in the Mochas, and other Asiatic varieties, they are of a yellowish stone-colour, which is acquired by age, to which probably much of their superior quality is also referable. These berries are principally composed of a mass of albumen, which is rolled up, and encloses the small cotyledons and embryo; they are convex on the outer side, and flat on the inner side, with a deep groove at the folding in of the albuminous coating; the two seeds lie within the pericarp, with their flat surfaces applied to each other.

The Coffee shrub is now cultivated in almost every tropical country; we receive it from the East and West Indies and South America. It is usually grown in plantations, and hand-gathered or shaken from the trees when ripe. Latterly the plantations in Ceylon have been infested with a species of Coccus (called the brown-scale), an insect allied to that which infests our pear-trees, to the cochineal-insect, and to the well-known lady-bird fly. 
The coffee-berry is always prepared for use by roasting; in this state it is not only more agreeable, but its peculiar power of stimulating the nervous system is increased. This property has long been supposed to reside in a peculiar substance which has been separated both from the berries and the leaves of the plants, and until lately was described as a peculiar principle, under the name of Caffeine; it is now however believed to be identical with the Theine of tealeaves. Dr. Gardner has recommended the coffee-leaf as a substitute for that of the tea-plant, and examples of leaves, prepared for the purpose, were exhibited at the Exhibition of 1851 ; but the coffee-bush would receive too much injury from the loss of its leaves to make it desirable to carry out this proposition. The quantity of coffee imported is enormous : the total amount imported in 1850 was estimated at 22,000 tons, of the value of $£ 566,822$; considerable quantities are again exported to the States of Europe and our colonies in Australia.

Like tea, coffee has been much imitated, and there are numerous substitutes and adulterations; of these, the most important is Chicory, a dark-brown powder, made from the roasted roots of the Cichorium Intybus, a handsome composite plant, indigenous to the temperate parts of Europe. 
SUBSTITUTES FOR COFFEE.

The tap-roots, which are large, are sliced and dried in kilns; they are then roasted in a manner similar to coffee, and reduced to powder; this, added to coffee in small quantities, is considered by many persons to improve the latter, and until lately its admixture was permitted by the Legislature, but is now prohibited. The adulteration can easily be detected, owing to the fact that roasted coffee imparts its colour only very slightly to cold water, but chicory colours it a deep reddish-brown; besides which, the latter sinks readily, but coffee will not, without difficulty and long soaking.

In the Turkish Collection of Raw Produce at the Great Exhibition, a curious seed was shown under the name of "Kenguel," from Kaissarieh, which in that country is roasted and used as coffee. There were two varieties shown: they were the seeds of a species of Gumillea (Nat. Ord. Cunoniacea).

The following are also used, either as substitutes or as sophistications for coffee :-Dandelion Root (Leontodon Taraxacum), prepared as chicory. Rye. Chick-p̌eas (Cicer arietinum). Broom-seeds (Spartium Scoparium: Nat. Ord. Leguminosa). The seeds of the Yellow Water Iris (Iris Pseudacorus: Nat. Ord. Iridacea) ; and the common Horse 
Bean. Many other seeds are roasted and used for one or both of the above purposes.

CocOA, CocaO, or CACAO.-The seeds of a small tree indigenous to the West Indies and tropical America, Theobroma Cacao. (Nat. Ord. Byttneriacece.) (Plate I. fig. 3.)

The seeds of the Theobroma are borne in a large oval capsule, rather pointed at each end; when ripe, the capsule is about four inches in length and two inches in diameter at the middle; the seeds are in the middle of the capsule, enclosed in a pulp, and closely packed round a central placenta, so that when the capsule is removed, the cluster of seeds resembles a short cob of Indian corn. They contain large quantities of a peculiar solid oil called the "butter of Cacao." Some qualities of the seed are possessed of considerable acridity, which is removed by burying the seeds for thirty or forty days; this however induces mouldiness.

The tree is ornamental, having fine dark-green shining leaves, with a wavy surface; and clusters of small white flowers. From the seeds, both chocolate and cacao, or cocoa, are manufactured. For the former, the seeds are freed from the husk, roasted and ground, and then mixed with sugar, and flavoured with vanilla, sassafras nuts, or some other aromatics. Cocoa is manufactured by grinding up the nuts 
without shelling them, a quantity of suet being added during the process of grinding.

Amongst the poorer classes in Italy and Ireland a drink is prepared from the husks which are separated in making chocolate. These husks are largely imported from Trieste and other Italian ports under the name of "Miserable." It is said that the beverage prepared from this is very wholesome and agreeable. Both chocolate and cocoa are very much adulterated with wheaten and potato flour, etc. The quantity imported in 1851 (chiefly from Brazil, Guayaquil, and Trinidad) was about 2000 tons, of which only about 580 tons were re-exported. (Poole's Statistics.)

SUGAR. - The saccharine matter from the juice of the Sugar-cane, Saccharum officinarum. (Nat. Ord. Graminacea.) (Plate I. fig. 5.) The Sugar of China, of which small quantities have reached this country, is supposed to be from S. Sinense, a distinct species..

That the Sugar-cane was known to the ancients is most certain, as various of the writers of antiquity refer to it. Dr. Pereira, in his elaborate and invaluable work on 'Materia Medica and Therapeutics,' gives the following interesting historical account of Sugar :-_"The manufacture of sugar is said by Humboldt to be of the highest antiquity in China. 
Cane-sugar was known to the ancient Greeks and Romans, and was considered by them to be a species of honey. Possibly Herodotus refers to it when he says that the Zygantes make honey in addition to that which they get from bees. Theophrastus calls it mel in arundinibus (honey in reeds); Dios-

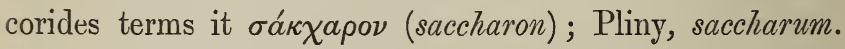
Humboldt adopts, too hastily, I think, the opinion of Salrnasius, that the latter writers meant the silicious product of the bamboo, viz. Tabasheer; for, in the first place, as they arrange it with honey, it was probably sweet, which tabasheer is not; secondly, the Sanscrit name for sugar is sarkura; thirdly, a passage in Lucan (lib. iii. v. 237) seems distinctly to refer to the sugar-cane: 'Quique bibunt tenerâ dulces ab arundine succos.' Surely no one will pretend that the bamboo is tenera arundo (slender reed)."

All we know of the origin of the sugar-cane is, that it was first known in Asia, and that it has not been found wild in any other part of the world; its cultivation has however spread from the Old World to the American continent and islands, where it now forms perhaps the most important vegetable product.

The sugar-cane is a gigantic grass, growing from six to twelve feet high; it is solid, being filled with pith and sac- 
charine juice, and jointed at very short intervals; the panicle, or flower-head, is large, often more than two feet long, elegant and feathery, from the flowers being surrounded with fine long reddish-coloured hairs, whilst the soales of the flower are of a pale rose-colour. The art of the cultivator has originated numerous varieties.

The sugar-cane is a perennial plant, and when ripe is cut down; the canes are then taken to the mills, where they are subjected to great pressure between iron rollers, by which the cane-juice is separated; it is then mixed with lime and boiled; by this process it is clarified; thence it is passed through a succession of boilers, and the water is removed by evaporation. When the sugar begins to assume its ordinary granular appearance, it is placed in a large shallow vessel, called a cooler, to crystallize. Here the peculiar process called claying takes place: a stratum of clay, moistened with water, is laid on the top, and as the water gradually filters through the mass of sugar, it carries with it much of the molasses which discolours it. The process of claying is said to have been discovered by accident: a hen, with muddy feet, having walked over a cooler full of sugar, it was noticed that where the clay from her feet had remained, the sugar beneath it was much lighter-coloured. If 
the molasses is merely separated by draining, the sugar is then termed Muscovado.

Lately a mechanical process for cleaning sugar from the molasses has been invented and patented by Mr. Leonard Hardman, of Liverpool, and others. It consists of an iron cylinder, pierced all over with small perforations; the sugar to be cleaned is put into this cylinder, which is made to revolve with great velocity; in the axis of the cylinder is a passage by which atmospheric air is drawn in, and passes with great force through the sugar, carrying out with it the molasses, which flies through the perforations; the whole being enclosed in an iron chamber, the molasses falls to the bottom, and drains off through a proper channel into a receiver: by this process the darkest sugar is rendered as dry and light-coloured as the finest clayed sugar. The refining of sugar is a process by which the remaining treacle and colouring matter is entirely removed, the bleaching being effected chiefly by the agency of animal charcoal and improved crystallization, by successive boilings and slow cooling at a regulated temperature.

Raw sugar is imported from the West Indies in large casks called hogsheads, in smaller ones called tierces, and in barrels ; from the East Indies in bags, chiefly made of jute- 
hemp, and called gunny-bags; from Havannah in large boxes; from Manilla in calico bags; from the Mauritius in mat bags; and from the Brazils in very large boxes or chests. The quanity imported in 1851 was 314,301 tons : of this enormous quantity 305,616 tons were consumed as raw sugar, 17,769 tons were refined, and 23,047 were exported to other countries.

Molasses, Melasses, or Treacle, is the uncrystallizable portion of the cane-juice, which, in the processes detailed above, drains out, and is used in varions ways, especially for sweetening the food of the poorer classes. The quantity imported in 1851 was 42,252 tons.

Rum is distilled from the refuse canes after all the saccharine juice has been expressed by the mills ; they are first fermented and then distilled. Of this spirit 4,194,683 gallons were imported in 1851.

Besides the sugar-cane, many other plants yield sugar; the principal of these are-

1. The Beet-root and Mangold Wurzel, or Mangel Wurtzel, two varieties of Beta vulgaris (Nat. Ord. Chenopodiacea), which are cultivated very largely on the continent of Europe, especially in France, where a great portion of the supply of sugar is from the juice of these large succulent roots. 
2. The Sugar Maple-Acer saccharinum (Nat. Ord. Aceracea), and probably other species of Maple.-From the juice of these trees, which runs out of incisions made in the stem, large quantities of a coarse uncrystallizable sugar is manufactured in North America. The Maple sugar is a domestic manufacture, and is only used in the country districts. The Indians of Canada make and sell it to the colonists, often packed in very elegant little baskets, made of bark, and embroidered with small quills of the North American porcupine (Hystrix dorsata, Linn.), dyed in various bright colours.

3. The Date (Phonix dactylifera).-From this useful palm, and also from $P$. sylvestris, the wild date and $S a$ guerus (Arenga) saccharifer (Plate IX. fig. 46), very much sugar is produced, by boiling the juice, which flows in immense quantities from incisions made in the spadices, or flower-heads; from $P$. sylvestris alone as much as 60,000 tons are made. These sugars are mostly consumed in India; much however is supposed to reach this country as cane-sugar.

Sugar has also been manufactured extensively from potatostarch, for the purpose of mixing with cane-sugar, but the manufacture is illegal in this country. 
CAPERS.

CAPERS. - The unexpanded flowers of Capparis spinosa, a native of the southern and eastern parts of Europe. (Nat. Ord. Capparidacea.)

The Caper is a handsome shrub, with a trailing habit, delighting in rocky situations, and particularly in the débris of old walls. The leaves are ovate and deciduous, with curious small hooked stipules. The flowers are produced singly on small stalks arising from the axils of the leaves; when expanded, they have four petals, of a delicate pinkishwhite colour; the stamens are numerous, and much longer than the petals, having the appearance of an elegant tassel.

The caper-plant is largely cultivated in Italy and France, especially in the neighbourhood of Marseilles and Toulon, but the chief supply to this country is from Sicily. As the plant continues flowering for six months, the caper-harvest continues through the whole of that period. The buds are gathered whilst very young, and thrown into casks containing vinegar and salt. When the gathering season is over, they are all sorted by hand according to their different sizes : the smallest, being the best, are called nonpareils; the second quality receive the name of capucines; both these are usually put into bottles, but those remaining after the selec. tion are put in small barrels and sold at a low price. 
The caper has been long used as a valuable and much esteemed pickle; but the date of its introduction is not satisfactorily known. In Italy it is called Caprioli, or Capero, in France, Caprier, whence our name Caper; the Germans call it Kapernstrauch. Mr. Poole gives about 40 tons as the annual imports.

Soy Bean.-The pods of Soja hispida. (Nat. Ord. Leguminosce.)

These pods are very rarely imported, but the sauce made from them is sent from India in large quantities, and is much esteemed. The sauce, or catsup (kitjap, Chinese), is called Soy, and is a thick black liquid, resembling treacle, but not so tenacious. About 500 or 600 gallons are annually received.

Oкra, Окrо, or Gомво.-The seed-vessels of Abelmoschus esculentus, or Hibiscus esculentus. (Nat. Ord. Malvacea.)

The Okra is an annual plant, a native of the East Indies, but has spread over a great part of the world. In the West Indies and in North America it is highly prized; in Turkey and Greece it is extensively used, under the name of Bamia; in India it is known under the names of Gobbio and Bandikai; and it is now much cultivated in France and other parts of Europe as a garden vegetable. Only the very young 
seed-pods are used; they contain an abundance of nutritive mucilage, which they communicate to soups in which they are boiled; they are used in various other ways, and are often eaten stewed with butter and spice. The pods, when dried carefully, retain their mucilaginous property for a long time, and in this state they are occasionally imported, threaded like beads, from Turkey and Greece. There is every reason to believe they may be easily grown in this country.

The pods are about an inch in length, of a conical shape, and covered with a golden-yellow hair, or pile, in the dry state; there are however several varieties, probably differing only in the age of the pods; they are only brought to this country as presents, chiefly for the Greek and Turkish merchants.

The Onion. Allium cepa. (Nat. Ord. Litiacea.)

This esculent root has been known from the earliest times. Thus in the Bible we read, "We remember the fish which we did eat in Egypt freely; the cucumbers, and the melons, and the leeks, and the onions, and the garlick," Numbers xi.5. It is a native of Egypt. Müller, in his 'Physiology of Plants,' mentions that an onion taken from the hand of an Egyptian mummy, perhaps two thousand years old, has been made to grow. Mummy onions are however liable to the same sus- 
picion as mummy-wheat, and, we doubt not, even philosophers have been imposed upon. The Onion now forms an important article of cornmerce; about 700 or 800 tons are annually imported in chests and boxes from Spain and Portugal.

Garlic. Allium sativum. (Nat. Ord. Liliacece)

Though much less used than the last, the Garlic is as ancient a vegetable as the onion. A few hundredweights are brought by the Spaniards, by whom this root is more used than by any modern nation.

THe Hop. Humulus Lupulus. (Nat. Ord. Cannabinacece.)

This well-known vegetable product, with two or three others, we have been compelled to place at the end of this chapter, as they will not come under any of the other divisions of our subject. It is indigenous both to this country and many other parts of Europe, and there are perhaps few plants in our hedge-rows more worthy of admiration; its very handsome foliage, resembling that of the vine, and its rapid growth and twining habit, spreading over the bushes and ormamenting them with its fine leaves and singular clusters of flowers, make it one of our most beautiful native plants. But, handsome as the hop-plant is in a state of nature, it is far more beautiful when cultivated; 
and those who have seen the hop-gardens of Kent, Surrey, Worcester, and Hereford, will be willing to confess that on growing crop has superior claims to our admiration. Under cultivation the hop is most luxuriant, and its clusters of strobiles, or female flowers, are more than quadrupled in size. When the seeds are ripe, the strobiles are gathered, dried, and packed in bags called pockets, and sent to the market. A few hundred pockets have been sent from the United States, but have not suited the English market. The quantity of hops raised in England is perhaps greater than all the rest of the world put together : in 185021,668 tons were cultivated and gathered; they occupied 43,127 acres, which paid to the revenue, as duty, an average of £6. 4 s. $6 d$. per acre. The quantity imported was 320 tons, from the United States, Belgium, and France; and the quantity exported was 98 tons, sent to the United States, Australia, Holland, Belgium, Germany, Cape of Good Hope, and Russia.

Truffles. Tuber cibarium. (Nat. Ord. Fungi.)

These curious fungi are produced entirely underground, chiefly in beech-woods; they appear to thrive best in the neighbourhood of beech-trees. Besides the one mentioned, there are several others, as T. astivum, T. brumale, T. mela- 
nosporum, T. griseum, T. moschatum, and T. rufum, all of which are highly prized for their delicate flavour, which is employed in sauces and soups. Dogs are trained to scent them out. We receive them from France and Italy preserved in oil, and many are found in England, particularly in the neighbourhood of Salisbury Plain. The imports are small, and the value very high.

Morell. Morchella esculenta. (Nat. Ord. Fungi.)

Another much-esteemed fungus, found growing in woods and orchards, and on banks under shady hedgerows. They are imported from Italy in a dry state, and are principally used for soups.

We now close the series of food-products; but it must not be supposed that we have exhausted the boundless profusion of nature. In order to keep the subject within the limits of a popular work like the present, it was necessary to confine ourselves to a selection, and we have chosen those vegetable productions which constitute, not only the food, but also the foreign commerce of our country; in doing so, we think most of our readers will acknowledge that man is largely indebted to the "Giver of all good things." 


\section{DIVISION II.}

\section{PRODUCTS EMPLOYED IN MANUFACTURES.}

\section{CHAPTER VII.}

VEGETABLES, USED FOR TEXTILE FABRICS.

Next to food, we are most indebted to the Vegetable Kingdom for clothing, and from the fibres of plants all but the most barbarous tribes of the earth partly derive the means of covering themselves. How the discovery was first made of the means of obtaining and weaving vegetable fibres we know not; but it is by no means improbable that man first learned this useful lesson from watching the instinctive labours of various animals; thus, in many birds' nests he would see the process of weaving, and in the nests of wasps and many other insects the manufacture of paper is clearly 
pointed out. Many passages in the Book of Genesis would lead us to infer that the "coats of skins" which God made for our first parents were soon exchanged for other raiment, and the "dwellers in tents" appear to have been too numerous for their dwellings to have been made of the skins of animals. The first vegetable fibre expressly mentioned is-

Flax. Linum usitatissimum. (Nat. Ord. Iinacea.) (Plate VII. fig. 33.)

Flax is thus alluded to in Genesis xli. 42: "And Pharaoh took off his ring from lis hand, and put it upon Joseph's hand, and arrayed him in vestures of fine linen." After this, the mention of linen and flax is frequent and unequivocal. It would also appear that Egypt was the native country of flax, or that at least its cultivation in that country reached a degree of perfection for which it has been celebrated up to the present time. Solomon purchased linen yarn in Egypt (2 Chronicles i. 16), and Herodotus mentions that Egypt was the great emporium of the flax trade. In support of these assertions, the microscope has satisfactorily proved that the cere-cloth in which the ancient mummies are rolled consists of the fibre of flax. It was even used in the manufacture of armour, for Herodotus speaks of a curiously-wrought linen corselet, preserved in the 
FLAX.

Temple of Minerva at Lindus in Rhodes, which had belonged to the Egyptian king Amassis, 600 years B. с. ; and in Pliny's time some mutilated remains of this same corselet were still in existence.

The flax-plant is extremely slender, growing about two feet in height, with a single stem crowned by a loose corymb of elegant light-blue flowers; it is cultivated in fields, and sown very thickly if a fine fibre is required, but more sparingly for coarser qualities. It has a remarkable range of temperature, thriving from the fields of Northern Europe to the plains of Tropical India.

The flax-crop is gathered by hand, the plants being pulled up by the roots and collected into bundles; this takes place usually after the flowering is just over, unless it is required to save both seed and fibre, when they are obliged to remain until the seed is ripe. The bundles are tied up and left in the field for twelve or fourteen days to dry; it is then carried to a pool of water properly arranged for the purpose; here it is steeped until the skin and mucilaginous parts are decomposed, and the tough fibres are set free; this process, called water-retting, usually occupies ten or twelve days. When taken out of the water, the flax is laid upon the grass of the bleaching-field for another ten or twelve days; by this 
operation its colour is much improved, it becomes dry, and is then ready for the scutching or bruising-mill, where it is beaten, to complete the separation of the fibres, which are then drawn through the heckling or combing apparatus; this combs out the flax and renders it fit for the manufacturer.

Other methods have been devised for rendering flax fit for use in less time; thus, about twenty-five years since, Parliament granted a secret or unenrolled patent to Mr. Lee for a method of steeping in hot water and softsoap, by which the fibre was said to be separated in the very short space of two or three hours; a process, lately brought into use, invented by M. Schenck, in which hot water is used for steeping, prepares the fibre in sixty hours; and a very ingenious method, invented by the Chevalier Claussen, by which the flax-fibre is reduced to the condition of cotton-wool, both in colour and fineness and in shortness of fibre. It is said that this patent process consists in soaking the flax in a hot solution of carbonate of soda, and afterwards dipping it in a weak acid solution; the disengagement of carbonic acid which takes place all through the texture of the flax breaks the fibrous tissue into its most minute divisions, in which state it is the flax-cotton. This article is said to work up 
well with cotton machinery, and to have, when manufactured, a finer and stronger texture.

Flax is largely cultivated in the United Kingdom, especially in Ireland, where it constitutes one of the staple productions. In 1850 the extent of land under flax cultivation in Great Britain and Ireland was computed at 120,000 acres ; the produce is very variable, ranging from three to ten hundredweights per acre; taking the mean of these quantities, the produce would be about 36,000 tons. Besides this, we received from abroad 90,339 tons, chiefly from Holland, Belgium, Italy, Russia, Egypt, and Turkey.

The rough and broken fibres which are detached from the skein during the process of heckling form the article called Codilla or Tow, which is much used by surgeons and in various pharmaceutical operations.

The seed of flax, or Linseed, will be mentioned in the chapter on oils.

Hemp. Cannabis sativa. (Nat. Ord. Cannabinacea.) (Plate VII. fig. 34.)

This is a plant of great antiquity; Herodotus, 2500 years ago, spoke of its cultivation by the Scythians, who, he said, made garments of it as fine as flax-linen. Its use had become so general amongst the Romans in the time of 
Pliny, that they commonly made ropes and cordage of it. In his 'Illustrations of the Botany of the Himalaya Moun-

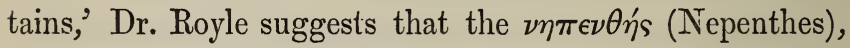
"assuager of grief," of Homer, was the hemp-plant, the narcotic power of which was known to the Scythians, for Herodotus also states that they excited themselves to "shouts of exultation" by inhaling its vapour. In reference to this property, it is also known in India as the "increaser of pleasure," the "exciter of desire," the "cementer of friendship," the "causer of the reeling gait," the "laughtermover," etc. Our English word hemp appears to be derived from hennip, a name applied in India to one of the numerous substitutes for hemp.

The native country of the hemp is not known, but most probably it is some part of India. Like the flax, it has a most extraordinary power of adapting itself to climate, its range of cultivation extending from the northern parts of Russia to the tropical plains of India ; it thrives admirably in Europe and North America and also throughout the whole of Africa. One remarkable characteristic of the hemp-plant when growing in tropical countries is that the value of the fibre is much diminished, but another quality is developed-it becomes powerfully narcotic, and exudes 
HEMP.

a peculiar resinous matter from its leaves, flowers, and the smaller stems. This product, called Churrus, is collected in Central India by men clad in leathern aprons, who rush backwards and forwards through the hemp-fields, knocking the plants about violently; by this means the soft resin adheres to the leather, from which it is scraped off. A finer variety, called Momeea, is collected by hand in Nipal; it is also termed Waxen Churrus, and fetches a very high price.

According to Dr. O'Shaughnessy, the Churrus has most remarkable intoxicating effects; in his work 'On the preparation of the Indian Heinp, or Gunjah,' he says that, in moderation, it produces increase of appetite and great mental cheerfulness; in excess it causes a peculiar kind of delirium and catalepsy. One of the cases mentioned by him is most remarkable, and would seem to account for some of the wonderful feats of the Fakeers and other religious devotees of India :- "At two P.M. a grain of the resin of hemp was given to a rheumatic patient; at four P.M. he was very talkative, sang, called loudly for an extra supply of food, and declared himself in perfect health; at six P.M. he was asleep; at eight P.M. he was found insensible, but breathing with perfect regularity, his pulse and skin natural, and the pupils freely contractile on the approach of light. Happening by chance 
to lift up the patient's arm, the professional reader will judge of my astonishment, when I found it remained in the posture in which I placed it. It required but a very brief examination of the limbs to find that the patient had, by the influ. ence of this narcotic, been thrown into that strange and most extraordinary of all nervous conditions-into that state which so few have seen, and the existence of which so many still discredit-the genuine catalepsy of the nosologist. We raised him to a sitting posture, and placed his arms and limbs in every imaginable attitude. A waxen figure could not be more pliant or more stationary in each position, no matter how contrary to the natural influence of gravity on the part; to all impressions he was meanwhile almost insensible." This extraordinary influence was produced upon other animals as well as man; after a time it passes off entirely, leaving the patient perfectly uninjured by it.

Owing to this peculiar property in hemp grown in tropical countries, it has been thought by many botanists that the narcotic hemp was a distinct species, which they called Cannabis Indica; this is now known to be an error, though probably it is a distinct variety.

In India, besides the churrus, the herb is dried for smoking under the following names:-Gunjah, the dried 
HEMP.

hemp-plant after it has flowered, and from which the churrus has not been removed, and Bang, Subjee, or Sidhee, the larger leaves and capsules dried without the stalks.

When the Bushmen, or Bosjesmans, of Southern Africa were in England, they smoked Gunjah in pipes which were formed of the tusk or canine tooth of some animal; it was about three inches long, and perforated quite through, leaving only the enamel; this rude pipe they stuffed full of the dried hemp, and smoked it as more civilized men do cigars. In many parts of Asia the use of narcotic hemp has long been known. The Saracens called it Hashash and Husheesh. In the wars with the Crusaders men were intoxicated with this drug, and rushed into the camps of the Christians, committing great havoc; being totally regardless of death, they were termed Hashasheens, whence our word assassin.

The hemp grows as high as six to twelve feet, slightly branched, with a coarse foliage; it is closely allied to the hop and the nettle, both of which are possessed of the tough fibrous qualities of this plant. The plants are moncecious, that is, they have their stamens and pistils in separate flowers on the same plant ; the flowers are small, yellowish-green, and inconspicuous; the seed is produced in great abundance, and is 
useful for feeding small birds, and for the oil which it yields by expression. The mode of preparing the fibre is very similar to that described under Flax, but the fibre produced is much longer and coarser. Some of the fine Italian Garden Hemp is eight or nine feet long, and of a very fine quality; it is used chiefly for sail-cloths, sacking, and cordage. We receive the bulk of that which is consumed in this country from Russia, in which country and in Poland its culture has been brought to great perfection. Inferior kinds are also brought from North America and India. From Italy we receive the remarkably fine variety raised by spade culture and called "Italian Garden Hemp;" only small quantities of this sort arrive. The imports of 1851 were 52,452 tons, of which at least 45,000 tons were from Russia.

The varieties found in the markets are-

Polish Ryne Hemp; Petersburg Clean, Half-clean, and Outshot Hemp; White Crown Marienburg, Bengal, American, and Italian Garden Hemp.

Large quantitities are also cultivated in various parts of England.

Jute. Corchorus capsularis. (Nat. Ord. Tiliacea.) (Plate VII. fig. 35.)

The fibre of this plant has of late years become so gene- 
JUTE.

rally used, that it now rivals flax and hemp in its importance as a commercial product. The Jute plant is a native of the warmer parts of India, where its cultivation is carried on, especially in Bengal, to an immense extent. It is an annual plant, growing from twelve to fourteen feet in height. The valuable fibre is contained in the bark, a striking characteristic of the plants of this Natural Order. The flowers somewhat resemble those of the common Lime or Lindentree; they proceed from the stem in bunches of two or three on very short pedicels, and are succeeded by a capsular seed-vessel of a subglobose figure and rough fluted sides. The leaves are about four inches in length when full-grown, oblong-pointed, and serrated at the edges; the two lowest serratures near the petiole being curiously extended into two long pointed appendages. Short branches are produced from the axils of the leaves.

Jute, or Jute-hemp as it is usually called, is generally about eight feet in length; the fibre is fine and has a remarkable satiny lustre; it will not stand wet well, hence it is not well adapted for cordage or canvas, which has to withstand exposure to weather. In India it is chiefly used for making coarse canvas called gunny, of which bags and bales are made for packing other raw produce. In England 
its use is more extensive. Notwithstanding its unfitness it is often mixed with hemp for cordage; it is even mixed with silk in the manufacture of cheap satins, in which it almost defies detection. Its principal use is in making coarse cloth for bagging, and in making the foundation of inferior carpets, mats, etc. The quantity imported in 1851 was over 21,000 tons.

Sun, Shunum, TaAg, or Bengal Hemp.-The fibre of Crotalaria juncea. (Nat. Ord. Leguminosa.) (Plate VII. fig. 36.)

Another Indian plant, yielding a valuable substitute for hemp, coarser in quality than the last, but capable of withstanding exposure to wet much better. It is an annual, and in growth resembles our common Broom; its flowers, which are yellow, also resemble those of Broom. It grows from four to eight feet in height. The quantity imported is not very great, being only from 200 to 300 tons annually.

Manilla Hemp, Plantain Fibre.-The fibres from the stem of Musa textilis. (Nat. Ord. Musacea.) (Plate VIII. fig. 41.) A finer kind is made from the green petioles of the leaves.

The stems of plants in this Natural Order are made up of the united petioles of the leaves, and cannot be regarded as 
true stems. They contain such a remarkable abundance of spiral vessels that these can be pulled out by handfuls, and are sold for tinder. Each spiral vessel consists of six or seven fibres, which, when pulled out, constitute the Manilla Hemp. It is from the finer fibres, obtained from the petioles of the leaves, that many of the celebrated muslins of India are made.

The common Manilla Hemp is a fine round silky-looking fibre, nearly white; it is used extensively in making cordage, for which purpose it is admirably adapted. About 2000 tons are annually imported. The celebrated Manilla scarfs, handkerchiefs, and the superior muslins, which rank so high amongst the oriental textile fabrics, are manufactured from the finest selected fibres, which are of great length and strength; and they are as fine and round as hair. The Manilla hemp imported into England consists only of the coarser plantain-fibre, which is used almost exclusively in the manufacture of cordage for ships, and is highly valued for its great strength and capabilities of withstanding the weather. The quantity imported is about 8000 tons per annum; but the returns for this and several other fibres being mixed up with those of "Hemp" (which commercially is a very indefinite term), it is impossible to ascertain 
the quantity with accuracy. Its value is about $£ 5$ per ton more than the best Russian hemp.

Aloe Fibre, Pita, or Pite Hemp. Agave Americana. (Nat. Ord. Amaryllidacea.)

A few bales of Pité hemp occasionally reach the English markets, chiefly from St. Domingo; it is an excellent material for cordage, resembling the Manilla more than the common hemp. It is made from the leaves of the Agave, or American Aloe as it is commonly called; in South America it is extensively used, particularly in Mexico, where paper is also made from it.

Pine-apple Fibre. - The fibre from the leaves of Ananassa sativa and one or more species of Bromelia and Tillandsia. (Nat. Ord. Bromeliacea.)

The leaves of most of the plants of this Natural Order contain an abundance of fine strong fibres; those of the the pine-apple were exhibited at the Great Exhibition, and some very fine muslins have been manufactured from them in the West Indies and Brazil; and from a species of Bromelia called Grawatha by the Brazilians excellent cordage is made. Pine-apple fibre has not yet however become an article of British commerce.

From another of the Bromeliacea, named Tillandsia 
usneoides, a curious article called Spanish Moss, and Barba Hispanica, is occasionally imported and used for the purpose of mixing with horsehair in stuffing cushions and other articles of furniture, and also for stuffing birds and other animals. This fibre is not however procured by the separation of the cellular matter of the leaves, in the manner described under Flax, but the plant produces these fibres in great abundance instead of leaves and roots. It is strictly an epiphyte; that is, it grows on the stems or branches of trees, and derives its nourishment by absorbing moisture from the atmosphere; for this purpose nature has furnished it with ample means, for instead of a number of leaves, the absorbent power of which would be limited, the fibres are produced in large tufts, and when growing are coated with a spongy absorbent surface, the peculiar black horsehair-like fibre constituting merely the central part for the purpose of strengthening these spongy strings, which resemble in their appearance the aerial roots of many of the epiphytal Orchidacea, and, like them, perform the functions of both leaves and roots.

Coir, Kyar, or Cocoa-nut Fibre.-From the husk of the common Cocoa-nut, Cocos nucifera. (Nat. Ord. Palmacea.) (Plate IX. fig. 44.)

This fibre, which is nearly as strong as hemp, and if pos- 
sible withstands the action of water better, is produced in immense abundance in India and other places; but it is chiefly in the East that it is collected and prepared for the purposes of matting and cordage. Its preparation is very simple, consisting of little more than beating the husks to separate the fibres, which are dry and but loosely held together, and afterwards drawing them through a coarse comb or heckle, by which the refuse is cleaned out; it is then spun into yarns of different thickness and exported largely to Europe, where it is now extensively manufactured into valuable ropes, door-mats, and matting. In India it is very generally used as cordage for vessels, and for fishing nets; its lightness recommends it especially for the latter purpose. Its durability is surprising, and perhaps no vegetable fibre will resist so long the injurious action of alternations of dryness and moisture. The Coir-fibre is also made into scrubbing-brushes, which are more durable than those made from bristles, and the husk before the Coir is removed is used by the poorer classes as an excellent substitute for scrubbing-brushes. The imports of yarn and rope are greatly increasing, the quantity imported in 1850 being, as nearly as can be ascertained, 10,661 tons, chiefly into London and Liverpool, from Ceylon and Bombay. 
China Grass.-The fibre prepared from Bohmeria nivea: the Snowy Nettle, or Urtica nivea of Willdenow. (Nat. Ord. Urticacea.) (Plate VII. fig. 37.)

The knowledge of the fact that this very superior fibre is derived from the above plant, is one of the invaluable results which have arisen from the establishment of the Museum of Economic Botany at Kew, under the superintendence of the eminently practical and scientific botanist Sir William J. Hooker.

Until very lately the Chinese were the sole possessors of the secret of making their celebrated grass linen; but the plant having been raised in the Royal Gardens, the question was set at rest, and the plant figured, in 'Hooker's Journal of Botany,' vol. i. The plant is now cultivated largely in various parts of India, and bids fair to become a most important article of commerce. At present our method of preparing it is not sufficiently perfect, but we are making rapid progress in its improvement, and may hope that grass linen, equal in quality to that of China, will ere long be as cheap and plentiful as that made from the flax. This Bchmeria is a coarse nettle-like plant, deriving its specific name from the white colour of the under side of the leaves.

The imports at present have only reached between 300 and 400 tons per annum. 
New Zealand Flax. Phormium tenax. (Nat. Ord. Liliacea.)

The Phormium is a coarse-growing plant, inhabiting the marshy places in New Zealand; it resembles somewhat the common yellow Iris of our ponds in its foliage, which is very long and sword-like. The flowers are burne in large trusses or corymbs; they are of a brownish-red colour, not very ornamental. The fibre is extracted from the long leaves by drying, maceration, and heckling, as in the instance of other similar products. The coarser qualities make good ropes, and very fine linen is manufactured from the finer selected fibres. The quantities imported are at present inconsiderable.

Gommutr, or Ejow Fibre. Arenga (Saguerus) saccharifera. (Nat. Ord. Palmacea.) (Plate IX. fig. 46.)

This is one those singular productions of the Palm-tribe occasioned by the splitting or decay of the leaf-stalks. After the leaf has decayed the base of the stalk is left clasping the stem; the loose cellular matter of these persistent petioles soon decomposes, and leaves the tough fibres behind, often beautifully arranged exactly as when growing; gradually however they become detached and hang loosely about, giving the stem a very ragged appearance. To the 
natives of the tropics these naturally prepared fibres are invaluable, furnishing them with materials for canvas, cordage, and a varity of economic purposes; those of the Arenga or Gommuti palm, supply this material in great abundance to the inhabitants of India, who however keep most of it for their own use; very small quantities only reaching this country, where it is not likely to be much used, for, though very strong and not liable to injury from wet, the stiffness of its fibres prevents its being made into neat cordage, and it does not possess much elasticity.

Piassava, Praçaba, Monkey Grass, or Para Grass. Attalea funifera. (Nat. Ord. Palmacea.) (Plate VIII. fig. 40.)

This fibre is produced in an exactly similar manner to the last, but upon a larger palm. The Attalea is one of the most elegant of its graceful tribe. Its stem (caudex, botanically) rises from twenty to thirty feet, as straight as an arrow, and tolerably smooth. From the top of this rises the tuft of pinnated fronds or leaves, which are of great length, often nearly twenty feet. Before the decay of the petioles, the fibres become detached at the margins of their bases; these fibres are produced in such quantities, hanging down ten or twelve feet in tufts, that they have caused 
the name of rope-bearing (funifera) to be given to this species. The fibres are thick, often about the size of the small green rush. They are remarkably round and not very pliable; they are neither woven nor spun in this country, but are much employed in making brushes and brooms. The brushes of the street-cleaning machines are always made of piassava. For a long time the Attalea was only known by its fruit, the Coquilla-nut, and the names Cocos lapidea and Lithocarpus cocciformis were given to it; but, thanks to the Kew Museum, the question was solved in that establishment, and those curious nuts, and the "Monkey Grass" of Para, were proved to be products of the same plant. Since then the trade in piassava has very. much increased; it is almost exclusively furnished by the provinces of Ceara and Para, in Brazil. About 800 tons were imported in 1851.

There are two or three materials which, though not strictly speaking vegetable fibres, for textile fabrics, nevertheless are so closely allied to that class of vegetable products that they must be described in this place.

BasT.-The inner bark of Tilia Europaa. (Nat. Ord. Tiliacea.) This is the common Lime or Linden-tree of our woods and hedgerows; but it is only in Northern 
Europe, and more especially Russia, that it is used in mak. ing the Bast mats. For this purpose the stems have longitudinal cuts made through their entire length, at the proper season; the cuts are so made that the whole of the bark comes off in long strips. The outer and inner barks easily separate, and the latter being dried is the material we call "Bast." This is then plaited into mats about a yard and a half to two yards square, which are most extensively used for packing various kinds of goods, and for lining the holds of vessels intended to receive corn; they are also much used by gardeners, nothing better having yet been found for the purpose of tying up plants. It is computed that the enormous number of $14,000,000$ are annually imported into Great Britain from the various ports of Russia, but chiefly from Archangel.

Rattans, Rattan Canes.-Calamus Rotang and various other species. (Nat. Ord. Palmacea.) (Plate VIII. fig. 39.)

These very singular palms grow in tufts of very long slender stems, with the leaves at considerable distances apart. They rise amongst the larger trees of the tropical forests, over which they throw their immensely long stems, giving the appearance of cordage stretched from tree to tree. These stems are remarkably flinty on 
their surface, this silicious covering giving them considerable hardness and a glossy appearance; the leaves have much of the same flinty character ; they are pinnated, and often terminate in tendrils. C. rudentum is said to produce stems five hundred feet in length, which are much used by natives in making ropes of immense strength, which they employ in catching elephants, and for other purposes requiring great strength. $C$. verus is another species, producing much smaller stems about twenty feet in height, which are used as rattans, chiefly by the natives of India, in weaving into wicker-work of various kinds. The use of the common rattan in this country is very similar, being chiefly used for forming bottoms for chairs; but its native applications are very various. The rattans are imported in bundles, each cane being seldom less than twelve or sixteen feet in length and once doubled up; the consumption is very great in this country, being estimated at about 75,000 bundles of 100 canes each, or 7,500,000 canes annually.

Bulrushes. Scirpus lacustris. (Nat. Ord. Cyperacea.) The tall Club-rush can only claim to be ranked amongst vegetable fibres used in textile fabrics from its now rare use in weaving mats and chair-bottoms. Its principal consumption is by the coopers, who use it to put between the 
BULRUSHES.

staves of casks intended to hold liquids ; the pithy structure of these rushes causing them to swell when moist, they close any interstices between the staves which otherwise are not quite water-tight. They consist of a single culm, or stalk, rising to the height of six or eight feet, about half an inch in diameter at the base and pointed at the top; the tuft of brown inconspicuous flowers coming out at the side of the stalk near the top. It grows in marshy situations on the borders of rivers and fresh-water lakes in many parts of Northern Europe, but particularly in the Netherlands. Many vessels laden with bulrushes, as they are called, arrive in England annually from Holland and Belgium. Owing to their lightness, these vessels do not bring more than thirty or forty tons of rushes each voyage ; nevertheless more than a thousand tons are annually imported; the returns for 1850 gave the number of bundles as 40,000 , but this was greatly below the real number, which could not be correctly ascertained.

Of those vegetable fibres which are of commercial importance, and belonging strictly to this division of the subject, there are one or two which differ from all the preceding in their botanical characters, and one of these is more extensively used than any of those already described. The 
vegetable fibres we have noticed are all derived from the stems or leaves of the plants yielding them, but the Cotton Wool and one or two similar fibres are found in the seedpods of the plants producing them.

Cotron WooL.-The woolly covering of the seeds of several species of Gossypium. (Nat. Ord. Malvacea.)

No history of the cotton-plant has ever yet been published equal to the highly erudite work of Dr. J. Forbes Royle 'On the Culture and Commerce of Cotton in India and elsewhere,' from which source the following historical facts are gleaned. The earliest mention of cotton with which we are acquainted is found dated 800 years B.c. in the Sacred Institutes of Manu, in which it is mentioned so repeatedly as to imply that it was in common use at that time by the inhabitants of India. Dr. Royle says he has been informed by Professor Wilson " that cotton and cotton cloth are mentioned (in that book) by the Sanscrit names kurpasa and karpasum, and cotton seeds as kurpas-asthi. The common name, kupas, indicating cotton with the seed, is no doubt derived from the Sanscrit name, and is in common use all over India, and may even be heard occasionally in Manchester. In Book ii. p. 44 of Manu, cotton is mentioned in a manner to indicate the esteem in which it 


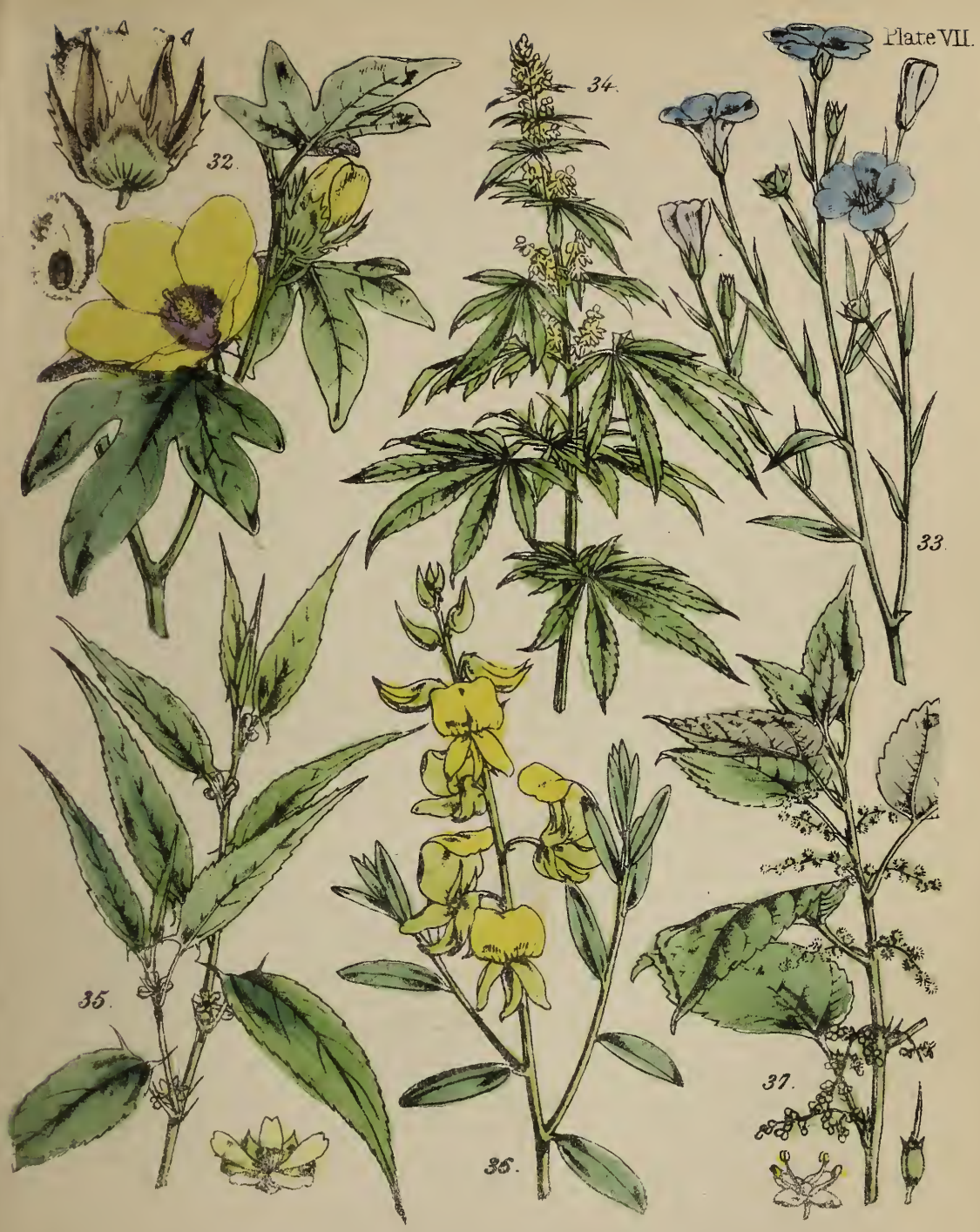

32 ivtton Plist

33. Flax Plant.

35. Tute

36. Surn Hemp

34. Hernp

37 China freas: 

COTTON.

was held; for it is said that " the sacrificial thread of a Brahmin must be made of cotton, so as to put on over his head, in three strings; that of a Cshatriya, of sana (sunhemp) only; that of a Vaisya, of woollen thread." These were probably three orders of Priests-the Brahmins, Cshatriyas, and Vaisyas. "In Book viii. p. 197 we have evidence of the minute attention paid by the Hindoos to the mechanical arts, and of the antiquity of the process of starcling; for it is directed,- ' Let a weaver who has received ten palas of cotton-thread, give them back increased by eleven of the rice-water, and the like used in weaving; he who does otherwise shall pay a fine of twelve panas." "

Another passage given by Dr. Royle, upon the authority of Professor Wilson, would seem to imply that cotton, and the process of starching it, were known at a very much earlier period than that already alluded to ; it occurs in the first book of the 'Rigveda,' Hymn 105, v. 8, written probably fifteen centuries before the Christian era: "Cares consume me, Satakratu, although thy worshiper, as a rat gnaws the weaver's threads." It is suggested by the eminent Sanscrit scholar that the threads of the weaver were of starched cotton, and that the rats were tempted by the starch with which the fibres were dressed. 
The mention made of cotton in the Scriptures ranks next in antiquity to those above recorded; it is however obscure, and would not easily be noticed even by the learned reader. Dr. Royle's own words will best explain it. "In the Book of Esther the word karpas occurs in chapter i., verse 6, in the account of the hangings in the court of the Persian palace at Shushan, on the occasion of the great feast given by Ahasuerus; where 'were white, green, and blue hangings, fastened with cords of fine linen and purple to silver rings and pillars of marble.' The word corresponding to green is in the Hebrew karpas, and is rendered in the Septuagint and Vulgate by the word carbasinus. It seems to mean cotton cloth, or calico, formed into curtains which were white and blue. Such may be seen throughout India in the present day, but padded with cotton and used as a substitute for doors and window-shutters, and known by the name of purdahs. The colours are usually either blue and white, or red and white. They may be seen in the Hall of Audience of the Emperor of Delhi, which is described by Bishop Heber as a 'beautiful open pavilion of white marble, richly carved, flanked by rose-bushes and fountains, and some tapestry and striped curtains hanging in festoons about it." Dr. Royle-also with much probability suggests that 
the curtains found at Nineveh by Dr. Layard, and which fell to pieces when touched, were also of cotton.

Herodotus describes the celebrated cuirass which the King of Egypt Amassis sent to Sparta, already mentioned in the article on Flax, as adorned "with gold and with fleeces from trees." "Theophrastus describes the trees from which the Indians made cloths, as 'having a leaf like that of the black mulberry, the whole plant resembling the dog-rose. They set them in the plains arranged in rows, so as to look like vines at a distance.' Nearchus described the natives as having garments made with this tree-wool, 'which reached to the middle of the leg, a sheet folded about the shoulders, and a turban rolled round the head ;' a description which would apply to many of them in the present day."

Arrian, a merchant and an author, probably of the second century, is the first who describes cotton goods as articles of coinmerce brought by Arab merchants to Aduli, a port on the Red Sea. That cotton clothing was also used by the Greeks and Romans is most probable, and was signified by the terms karpason in the Greek, and carbasus or carbasum in the Latin. Mr. Yates, in his work 'Textrinum Antiquorum,' remarkable for its erudition, ch.i., p. 343, states that the earliest notice he has found of the word carbasina. 
is in Statius; and he infers that cotton cloths of some kinds were known to the Greeks as early as 200 years before Christ. Perhaps cotton is meant when, long before Schönbein's discovery, "Exhibuit vivos carbasus alba focos," when the vestal virgin, upon the extinction of the flames on the altar committed to her care, threw upon the ashes a fillet of muslin from her head and saved her life by its ignition.

By the Roman authors it was frequently mentioned, especially in later times. Thus Cicero speaks of fine tentcloths as "carbasea vela," and Pliny mentions them as "carbasina vela." Virgil speaks of cotton sails for ships, when he says "Tumidoque inflatur carbasus Austro;" and it. would appear that cotton muslins were worn as clothing in his day, for he says, "Tenuis glauco velabat amictu carbasus." Similar quotations might be furnished in abundance, but we will again return to Dr. Royle, and follow him through his history of this wonderful material, much of which is drawn from the work of Mr. Yates above quoted. "Gossypium is supposed to be one of the names used to designate cotton in the fourth century, and much earlier than that it was called Gossympinus by Pliny." "Later still the name bambacinus, made of cotton; bambacinum, 
cotton cloth; bambacarius, a dealer in cotton cloth; and in Italian bambagio, bambagino, and bambacino." (Yates, 1. c., p. 354.) These names were supposed to have originated from some misapplication of the names of the silkworm, bombyx, and silken, bombycinus; whence also with equal incorrectness our term bombazine, applied to a woollen fabric.

"From India cotton appears to have spread into China, for it does not seem to have been used in the ninth century, as the two Arabian travellers who then visited China observed that the 'Chinese dressed not in cotton as the Arabians did, but in silk;' and it is supposed that the cotton manufacture was not established there until the thirteenth century." From India it also spread into Persia, Arabia, Egypt, Central and Western Africa, and Southern Europe.

There is positive proof that it was in use in America at a very early period, and consequently that some species are indigenous to the New World, for "Columbus found it in the West India Islands. Cortes, in his Conquest of Mexico, is described as receiving garments of cotton among the first presents from the natives of Yucatan; also cotton cloths to cover his huts; and from Montezuma, cotton fabrics of 
fine and silk-like delicacy of texture;" and it was found afterwards to constitute the principal clothing material of the Mexicans. Magelhaens found the natives of Brazil employed it in stuffing their beds. Raw cotton and cotton fabrics have also been found in the ancient Peruvian tombs. Indigenous cotton-plants have been discovered in the Galapagos, the Sandwich Islands, the Sechelles Islands, in Java, Borneo, and other Indian Islands, and in the islands of the Chinese coast.

This remarkable product, the history of which so far has been chiefly drawn from the above-mentioned interesting work of Dr. Royle, is certainly produced by several species, some of which are very distinct, whilst others are less easily distinguished. Different botanists have described the species of cotton as amounting to about twenty-four in number, but many of these are very questionable. The following species have been determined by Dr. Royle.

1. Gossypium Indicum, Lamarck; G. herbaceum, Linnæus. (Plate VII. fig. 32.) Native name Kotu hindee.Stem more or less branched, herbaceous, one anı half two feet high, in temperate climates; hard and wood-like and bi-triennial, four to six feet high, in its native and other warm countries; flowers bright yellow. Dacca cotton, from 
COTTON.

which the celebrated muslins of that locality are made, is one of the varieties of $G$. Indicum.

The nankeen-coloured cotton of China and other places is only an accidental variety.

2. G. punctatum, a perennial nearly allied to the last, growing naturally upon the banks of the Senegal, and in the country between it and Gambia.

3. G. obtusifolium, Roxburgh, shrubby and very branching. A native of Ceylon, but not cultivated.

4. G. arboreum. Stems tree-like, fifteen to twenty feet in height, flowers red; sometimes called G. religiosum; it is called Deo Kupas in Mysore, and by the natives of India is only used in making turbans for the head, and never for lower or under garments, being sacred to the deities. It is found in the island of Celebes, in Arabia, Egypt, and in India.

5. G. Barbadense. A shrubby perennial species, six to twelve feet in height; flowers yellow. In India it is called Bourbon Cotton, and is chiefly cultivated in the islands of Bourbon and Mauritius. It is from this species that the varieties called Sea Island, Upland, New Orleans, Georgia, Florida, Alabama and others were originated.

6. G. Peruvianum-Brazil Cotton. Flowers large and 
yellow; plant perennial and tree-like, from ten to fifteen feet in height. It furnishes the cottons of Brazil, Pernambuco, Bahia, and Peru. It is remarkable for producing its seeds in a curious kidney-shaped clump. Many others are mentioned by Dr. Royle as not producing commercial cotton; but he thinks that more accurate investigation may reduce all the species to these four: G. Peruvianum (or G. acuminatum), G. Indicum (or G. herbaceum), $G$. arboreum, and G. Barbadense, which are undisputed and well defined.

The cotton-plant is essentially a tropical plant, and admits of only very limited cultivation within the temperate zones. It is usually cultivated in fields or plantations, and treated as an annual plant, which practice is found to be better than allowing it to stand several years. The seed is sown in holes, eight or ten in each, a short distance apart, but sufficient to allow the growth of the plants, only one of which is suffered to continue in each place; maize is often dropped in the drills, and is suffered to grow amongst the cotton-crop. About eighty days after sowing the seeds, the plant produces its blossoms, which are handsome mallowlike flowers, either red or yellow; these are succeeded by pods or bolls, containing the seed and cotton, which are 
gathered when ripe, and the cotton covering the seeds removed by a peculiar apparatus called a gin. There are many modifications of the cotton-gin, but the principle upon which they all act is by saws with long teeth passing through the cotton; these pull tufts of the wool from the seed, while a pair of brushes keep the teeth clear and collect the cotton. Gins are worked either by hand or by machinery. Another process is used in some cotton districts, called bowing; the bowed cottons all come from America.

We receive cotton wool from North and South America, the East and West Indies, and from Egypt and Port Natal, in Africa. The quantity imported is almost incredible, amounting often to one million and three-quarters of bales, averaging three hundred and thirty-six pounds each.

Some of the statistics of cotton wool are exceedingly interesting. Thus in 1850 the average weekly consumption in England and Scotland was 29,125 bales. The exact imports of that year amounted to 1,749,295 bales, of which 272,400 were again exported chiefly to Northern Europe. The highest value for the Sea Island Cotton of the United States was $17 \frac{3}{4} d$. per lb. ; for Brazilian, $8 \frac{1}{2} d$. ; West Indian, $9 \frac{1}{4} d$. ; East Indian, $6 \frac{1}{4} d_{\text {. }}$; and Egyptian, $10 d$. The declared value of cotton manufactures exported from the United Kingdom 
in 1850 was $£ 28,252,878$. The value of those consumed in this country is assumed by Mr. B. Bole, in his statistics, to be three times the value of the material consumed, which would give $£ 52,000,000$; or $£ 80,000,000$ as the total value of one year's manufacture from the woolly covering of the seed of the cotton-plant! The number of factories employed in weaving and spinning cotton wool in England and Wales is 1753 , containing 223,626 power-looms, turning $19,173,969$ spindles, moved by steam-engines of the united power of 62,940 horses, and water-power equal to 1182 horses, employing 131,610 male persons and 160,052 females, or an aggregate of 291,662 human beings.

In Scotland the number of weaving and spinning factories is 168 , containing 23,564 power-looms, turning $1,683,093$ spindles, moved by steam-power equal to 7712 horses and water equal to 2842 horses, employing 8797 males and 27,528 females, or 36,325 persons. In Ireland, eleven factories, 2437 looms, 119,955 spindles, with steam-power equal to 353 horses, and water motive power equivalent to 1024 horses, employing 1094 males and 1843 females, or 2937 persons. Or for the United Kingdom, 1932 factories, employing a motive power equivalent to that of 82,555 horses, and employing 330,924 human beings, involving a 
capital of probably $£ 3,000,000$, all employed in working out a vegetable fibre which the beneficent Creator has bestowed for the protection of a small seed not larger than a pea, and for the clothing of the human race.

Vegetable Silk. Chorisia speciosa. (Nat. Ord. Sterculiacece.)

This curious production is called Arvore de Paina in South America, where it is extensively used in stuffing cushions, but cannot be woven in consequence of the individual fibres being perfectly smooth, not rough and adherent like those of the cotton. It resembles cotton wool, but has a beautiful satiny lustre, and is extremely light; it is not unlike the beautiful down of the Cotton-grasses (Eriophorum: Cyperacea) so common upon the moors of this country. Small quantities are occasionally imported for stuffing and probably for mixing with down of birds as an adulteration.

The Indian Grass Matting, so much esteemed in India and Europe, is made from Papyrus corymbosus. This material is not imported in an unmanufactured state, but woven into mats; it reaches us in very large quantities.

There are many other vegetable fibres used for textile and similar purposes in various parts of the world; indeed 
so numerous are they that our limits would be insufficient for their description. In India especially there are some of considerable importance; and as they have been made known to us by the indefatigable exertions of Dr. Royle, who collected and exhibited them in his magnificent series of raw produce at the Great Industrial Exhibition, it will not be out of place to give the names of those exhibited, of which we know the producing plants.

SunneE.-Fibre of the stems of Hibiscus cannatinus (Nat. Ord. Malvacea), called Palungeo, from Coimbatore. This is also called Brown Indian Hemp, Ambari, and Sun : this last name is more generally applied to another material.

String and ropes of the fibre of Bauhinia racemosa (Nat. Ord. Leguminosa), called Putwa, from Bhagulpore.

Jetee or Tongoose fibre, from the stems of Asclepias tenacissima (Nat. Ord. Asclepiadacea), from Madras.

Yercum fibres, from the bark of Calotropis gigantea (Nat. Ord. Leguminosa).

Fibre from the stalks of Parkinsonia aculeata (Nat. Ord. Leguminosa).

Pulas cordage, from fibres of the inner bark of Butea frondosa, a fine tree (Nat. Ord. Leguminosa).

Palmyra fibres, from the leaves of Borassus flabelliformis 
VEGETABLE FIBRES.

(Nat. Ord. Palmacea). This fibre resembled exactly a sample of one, which the author once saw prepared from the leaves of the fine Brazilian Carnauba palm, Corypha cerifera (Plate VIII. fig. 38).

Duchai Hemp, fibre of Asshynomene cannabina (Nat. Ord. Leguminosa).

Morgahee, African Hemp, or Bowstring Hemp fibres, prepared by hand from the leaves of Sanseviera Zeylanica (Nat. Ord. Liliacea), found all over the tropics of India and Africa.

Flax from Buhmeria candicans (Nat. Ord. Urticacea). Fibres of Neilgherry Nettle-Urtica heterophylla. (Nat. Ord. Urticacea.)

Caloee Hemp, Rhea fibre, from Urtica tenacissima.

Besides these East Indian fibres, there is one of some interest which has been occasionally imported from Owhyee, and probably other islands of the Pacific. One sample only has been seen by the author: it was called Pu-lu or Vegetable Silk, and was introduced experimentally for mixing with silk in the manufacture of hats,- -whether successfully is not known. After much difficulty the anthor ascertained that this substance was derived from the tree-ferns: the undeveloped circinate leaves of the growing axis being beauti- 
fully clothed with this vegetable silk, which in beauty is no mean rival to that produced by the silkworm. It resembles the unravelled fibres of rich orange-brown satin. A very small sample is in the Liverpool collection of Imports.

It is impossible to overrate the importance of the sub. stances comprised in this division; for although our first parents, upon their expulsion from Paradise, were clothed by God in dresses made of the skins of beasts, and the most savage tribes have always followed their example, nevertheless, as civilization has advanced, the art of weaving has become absolutely necessary to economize the limited resources of the animal kingdom, which, with the present population of the world, would be insufficient to furnish raiment for a fiftieth part of our race. Besides this, miles of canvas are spread upon the ocean, and thousands of miles of cordage are required to enable our vessels to navigate the waters of the globe. Vegetable fibres clothe millions of the great human family; vegetable fibres assist in wafting the commerce of the world from port to port, and carry along the floating batteries and castles which are the safeguard of our sea-girt isle. Vegetable fibres form sheltering tents for the armies of nearly all nations; and they furnish the means to industrious hands of earning the 
necessaries of existence,- too often, it is true, earned hardly and painfully, as we have been told by the immortal Hood in his "Song of the Shirt," the words of which are as undying as the feelings of love and charity by which they were dictated. If to our statistics of cotton we could have added information as to the number of half-starved, wretched, and broken spirits who are daily toiling for their bread, amid the roar of those 249,627 looms and surrounded by the dizzying whirl of those twenty-one millions of spindles, we should then see one of the dark scenes of life, which for our comfort is best hidden. We will look to a brighter picture.

"Yon cottager, who weaves at her own door, Pillow and bobbins all her little store ; Content though mean, and cheerful if not gay, Shuffling her threads about the livelong day ;

Just earns a scanty pittance, and at night

Lies down secure, her heart and pocket light.

She, for her humble sphere by nature fit,

Has little understanding, and no wit ;

Receives no praise, but though her lot be such

(Toilsome and indigent), she renders much ;

Just knows, and knows no more, her Bible true-

A truth the brilliant Frenchman never knew;

And in that charter reads, with sparkling eyes,

Her title to a treasure in the skies." 


\section{DIVISION III.}

\section{MISCELLANEOUS PRODUCTS USED IN THE ARTS AND MANUFACTURING PROCESSES.}

UNDER this division we rank a very heterogeneous assemblage of materials, many of them exercising immense influence in the commerce of nations. First, we have those which, by the peculiar influence of the chemical principle called Tannin (tannic acid) contained in them, convert the albumen and gelatine of animal tissues into tannates of those bases, thus forming compounds which are insoluble in water, hence the durability of leather. Next we have the varied materials of the dyers' art, carefully selected and requiring nice manipulation, and the powerful aid of the chemist, to produce the infinitely varied tints of colour which give beauty to the textile fabrics of the weaver; and, to close the series, we have the gums, resins, and oils, which are applied in numerous ways to the arts of social life. 


\section{CHAPTER VIII.}

TANNING MATERIALS.

The most generally used material for converting the skins of animals into the valuable economic article leather, is the bark of the common oak, and various less common species of the same genus. Several of the tanning materials are also used in dyeing.

$\mathrm{O}_{\triangle \mathrm{K}} \mathrm{B}_{\mathrm{ARK}}$. Quercus pedunculata. (Nat. Ord. Corylacea, Mirbel.)

This familiar tree needs no description. Some there are however who regard it only as furnishing material for those "wooden walls" which are both the glory and defence of our country; but valuable as is the timber of the oak-tree, its bark is also of great utility, furnishing perhaps the best known material for tanning hides and skins. This astringent property, found in all parts of the oak-tree, was known 
to the ancients, and was commented upon by Dioscorides. Besides the bark of $Q$. pedunculata, that of other species of oak not distinguishable as bark is mixed and used indiscriminately; particularly that of Q. sessiliflora. Much oakbark is of course furnished from our own forests, but a prodigious quantity is also exported from the continent of Europe, chiefly from the ports of Holland and Belgium; the foreign article is cut into small pieces about three inches in length. In 1852 we received 19,034 tons, and the home produce was 150,000 tons; this however probably embraced a large proportion of the bark of the Larch (Pinus Larix, Nat. Ord. Pinacea), which is also of great value, being only inferior to the oak.

CoRK-TREe BarK-Quercus Suber.-The bark of the cork oak, when young, that is, about twelve years of age, is of no use for the ordinary purposes to which cork is applied; but its removal, if performed with proper care, rather tends to the future vigour of the tree and improves its corkbearing qualities. The young bark so removed is imported to this country for tanning purposes under the above name; it usually comes from Rabat, in pieces about a foot in length, shaped very irregularly. We receive about three or four hundred tons annually. 
VALONIA.-The acorn-cups of Quercus Agilops. (Plate XII. fig. 60.) This oak is a dwarf shrubby species growing abundantly in the Levant; the acorns produced by it are very large, the cups often measuring over an inch in diameter; they have a whitish colour and a peculiar rough appearance, owing to their being covered externally with large reflexed woody scales. Valonia is very valuable for its tanning properties, and the abundance in which it is produced spontaneously. We receive it chiefly from Smyrna, whence not less than 12,520 tons were imported in 1850 . There are two articles, one called Camata (Plate XII. fig. 61 ), the other Camatina (Plate XII. fig. 62), which are also produced by Quercus Agilops. Camata consists of the half-grown acorns dried, and Camatina is the ovule enveloped in its involucre just after the flowering is over, in other words an incipient acorn ; so that these three materials are the seeds of this oak in three stages of development. Valonia is the least valuable of the three.

Mangrove Bark. Rhizophora Mangle. (Nat. Ord. Rhizophoracea.)-This tree is most abundant in tropical countries, on the marshy banks of rivers, where it forms an impenetrable jungle from the circumstance of its branches throwing down roots somewhat after the manner of the 
Banyan tree. Importations of the bark have been occasionally received from the West Indies, and more frequently from Africa, but it is by no means a common commercial article. Its only value is as a tanning material, and in this respect it is of second-rate importance.

ACaCia Bark. Acacia melanoxylon. (Nat. Ord. Leguminosa.) - This bark is extremely valuable in tanning processes; but as it is one of the natural products of Australia, shipments to this.country are very irregular and lately have been very scarce, its bulk almost precluding the possibility of its importation with profit. An extract made from this bark has however frequently been imported, and will probably at some future day form a valuable export from Australia, rivalling the Cutch and Gambir of India.

BaBool BaRK.-The barks of the Acacia Arabica and Acacia Catechu, generally mixed.-These barks, under the name of Babool, are extensively used in the East Indies, and have been occasionally, but without success, imported to England.

Pomegranate Bark. - The rind of the fruit of the Pomegranate, Punica Granatum. (Plate IV. fig. 19.)-A few packages of this rind or bark are occasionally imported from Barbary for tanning the finer kinds of leather; 


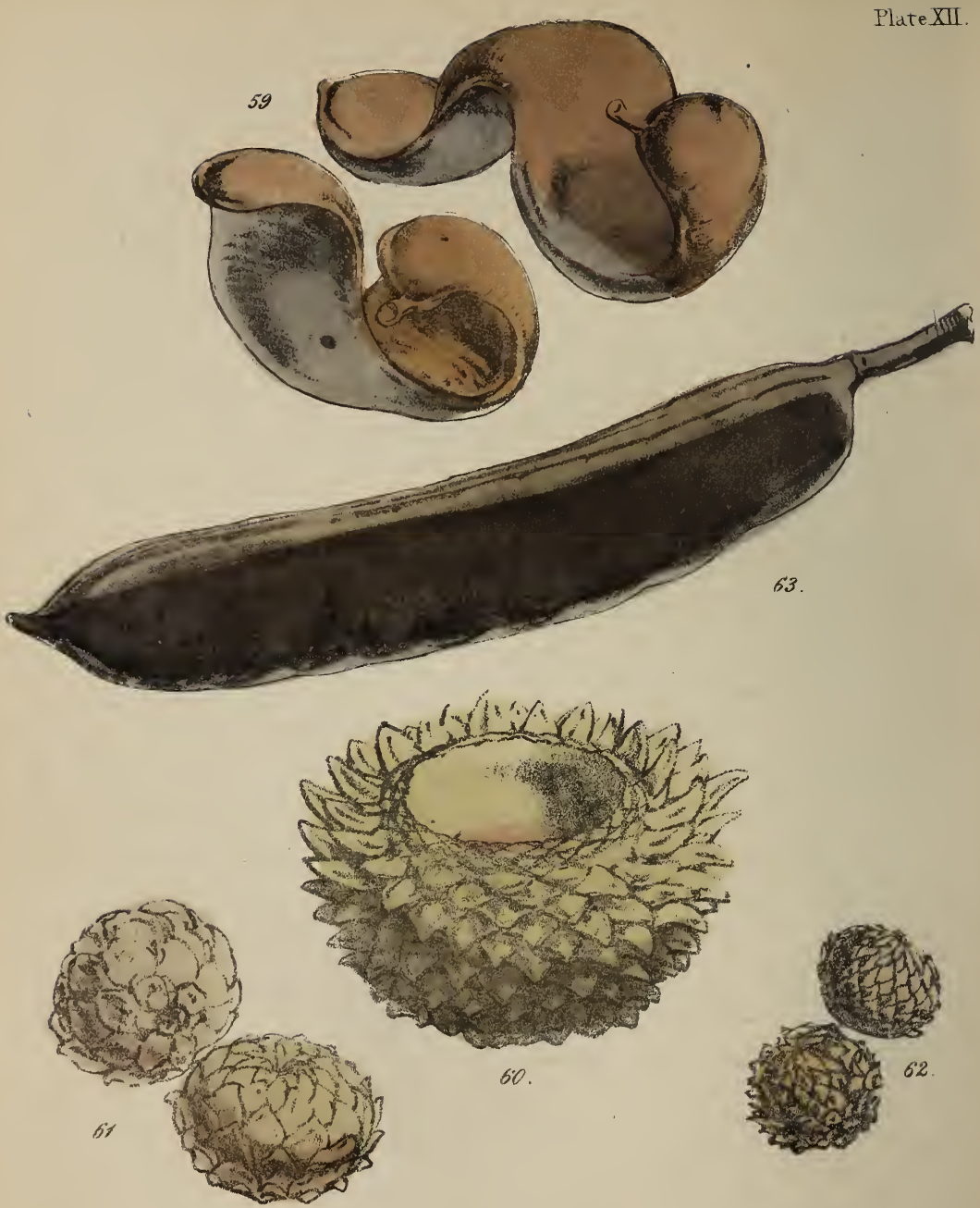

59 Brvi-dys

(i) Valonua

(i). Cizasta

62 ('mantira

เล Hipk 
it is said to form the principal material for tanning the celebrated Morocco leather.

Divi-Divr, Libi-dibi or Libi-divi (the native name).The seed-pods of Casalpinia coriaria. (Nat. Ord. Leguminose.) (Plate XII. fig. 59.)

This tree is a native of the sea-side marshes of Curaçoa, St. Domingo, Cartagena, and several other places on the Spanish Main. It attains a height of from fifteen to twenty feet, producing an immense number of small yellow laburnum-like flowers; these are succeeded by a pod varying from one to three inches in length and two-thirds of an inch broad, of a dark glossy-brown colour. As they grow, these pods become curled in a very remarkable manner, when short making merely one bend like the letter $\mathrm{C}$, but when of the full length, two curves, like the letter S. Dividivi is one of the most astringent of all vegetable substances, and consequently is of great value in tanning. At present it is produced in such enormous quantities naturally, that no need has yet been felt for its cultivation, but it would doubtless well repay the grower. It is not used by itself, but is generally mixed with oak-bark and valonia. We receive it chiefly from Savanilla, Maracaibo, Paraiba, and St. Domingo ; in 1851 more than 3000 tons were imported. 
Pr-PI. - The ripe pods or legumes of Casalpinia Papai (Nat. Ord. Leguminosa). (Plate XII. fig. 63.)-This tanning material more frequently comes mixed with Divi-divi, than as a separate importation, and when so mixed decreases the value of the latter. Sometimes, though rarely, small quantities of $\mathrm{Pi}$-pi are imported, but it is not much valued. Algarobilla, Algaroba.-The legumes of a species of Prosopis, supposed to be $P$. pallida (Nat. Ord. Leguminosa).-Most of the species of Prosopis have short roundish pods with a wavy outline longitudinally; the seeds therein are enveloped in a sweetish pulp, which in some of the species is also possessed of considerable astringency. When ripe the pods fall off the trees, and they soon decompose and run into a mass with the pulp, and a resinous juice contained in the shells of the pod. This mass is collected when dried, packed into bags, and exported; the material has a very destructive effect upon the bagging, so that it usually reaches this country in bulk, the packages becoming destroved on the voyage; it is not very useful, and is only occasionally imported. About 700 tons have been received at the port of Liverpool.

Neb-Neb.-The dried pods of Acacia Nilotica. (Nat. Ord. Leguminosa, Suborder Mimosea.) -These Minosa-pods, 
sometimes called Nib-nib, are much used by the Egyptian tanners; they are about two or three inches in length, flat and drawn in between each seed: this is a characteristic of the Mimosa tribe. A few importations have been seen in the British markets, but they are not in demand.

Catechu, Terra Japonica, Cutch, and Gambier.Under these names we receive very large quantities of vegetable extract which contains tannic acid in great abundance, and is consequently very valuable in tanning processes. The various names under which this article comes, serve to define several well-marked varieties, which probably originate entirely from the different modes of manufacture adopted by the natives in various localities of the Indian Empire, whence we derive the entire supply of this useful material.

Catechu is the extract of the wood of Acacia Catechu (Nat. Ord. Leguminosa), the seeds of Areca Catechu (Nat. Ord. Palmacea), and the leaves of Nauclea Gambir (Nat. Ord. Cinchonacea).

The Acacia Catechu is a small spiny tree rarely exceeding twenty feet in height; the wood is hard and heavy, the centre is of a very dark red colour, nearly approaching to black; it is from this portion of the wood the extract is made. In 
India it is made by the poorer natives, who move from place to place, selecting jungles where the Acacia is most abundant. They cut down the trees and chop the heartwood into chips, which they boil in water; when the water is deeply coloured, it is strained off, and submitted to the process of evaporation, fresh supplies of the decoction being added, until the whole by evaporation becomes thickened sufficiently; it is then poured out into clay moulds, and left to dry in the sun.

An interesting sketch, from the Letters of Dr. J. D. Hooker, published in 'Hooker's Journal of Botany,' will give a painful insight into the life of the "Kutt" makers of India.

"At half-past eight . M. it suddenly fell calm, and we proceeded to Chakuchee, the native carts breaking down in their passage over the projecting beds of flinty rocks, or as they hurried down the inclined planes which we cut through the precipitous banks of the streams. Near Chakuchee we passed an alligator, just killed by two men,-a foul beast about nine feet long, and of the Mager kind. More interesting than its natural history was the painful circumstance of its having just swallowed a child, that was playing in the water, while its mother was washing her domestic uten- 
sils in the river. The brute was hardly dead, much distended by its prey, and the mother standing beside it. A very touching group was this! the parent, with her hands clasped in agony, unable to withdraw her eyes from the cursed reptile, which still clung to life with that tenacity for which its tribe is so noted, and beside her the two athletæ leaning on their bloody bamboo staffs, with which they had all but despatched the animal.

"The poor woman who lost her child earns a scanty maintenance by making catechu. She inhabits a little cottage and has no property but her two Bhiles (oxen) to bring wood from the hills, and a very few household chat. tels, and how few these are is known only to persons who have seen the meagre furniture of the Dangha hovels. Her husband cuts the trees in the forest, and drags them to the hut; but he is now sick; and her only son, her future stay, was he whose end I have just related.

"Her daily food is rice, with beans from the beautifulflowered Dolichos, trailing round the cottage; and she is in debt to the contractor, who has advanced her two rupees, to be worked off in three months, by the preparation of $240 \mathrm{lbs}$. of catechu. The present was her second husband, an old man; by him she never had any children, and in 
this respect alone did the poor creature think herself very unfortunate, for her poverty she did not feel. Rent to the Rajah, tax to the police, and rates to the Brahminee priest, are all paid from an acre of land, yielding so wretched a crop of barley, that it more resembled a fallow-field than a harvest-field. All day long she is boiling down the catechuwood cut into chips, and pouring the decoction into large wooden troughs, where it is inspissated."

Dr. Hooker thus describes the Acacia Catechu:- "The plant is a little thorny tree (dire enemy of mine), erect, and spreading a rounded coma of well-remembered prickly branches. Its wood is yellow, with a dark brick-red heart: it is most productive in January, and useless in June."

The catechu made from the Acacia Catechu is also called Cutch and Terra Japonica. The first of these names is derived from cate, a tree, and chu, juice. The term Cutch is said to be also from the native language, in which it is called Kutt. The term Terra Japonica was applied by European pharmaceutists when the substance was first imported as a kind of astringent earth from Japan. In commerce one variety is termed Catechu, and another Cutch, although the source is the same. The former has been poured out upon mats, when about the consistency of honey, and 
dried in the sun; when sufficiently hardened, it is cut into small square pieces and thoroughly dried, and in this state packed into cane baskets for exportation. This variety has a light chocolate-brown colour, and the cubes are about an inch square, having an earthy fracture and external appearance. The other variety, Cutch, is of a darker colour, rich brown, with a shining appenrance and fracture; it comes much mixed with the broken leaves on which it has been laid to dry; it is packed in a similar manner to the catechu, but is most generally run into one mass.

Gambier, or Gambir, is an extract of the leaves of the Nauclea Gambir: this plant belongs to the Natural Oider of the Cinchonas, or Jesuits' bark trees. It is made by boiling the leaves and evaporating the decoction to dryness; in appearance it resembles cutch, but is not so glossy in its fracture, and rather lighter in colour. It is mostly imported from Singapore, where it is extensively cultivated.

Small quantities of a remarkably fine kind of catechu have occasionally been imported in the form of small round cakes, about one inch in thickness and two inches and a half in diameter, and rounded at the edges. These cakes are of a very dark brown colour, and rather glossy; they come in cases carefully packed, with a small piece of maize- 
leaf between each. This substance is called Kassu, and is known to be manufactured from the seeds of the Areca Catechu, or Betel nut, one of the palms.

Another vegetable extract, now very frequently imported under the name of Catechu from Pegu, is prepared from the Butea frondosa, a leguminous tree, with handsome peashaped flowers, very common in India; every part of the tree abounds in the astringent principle.

There are other extracts imported occasionally, for tanners' use, which also receive the common designation of Catechu, but the sources from whence they are derived is unknown. One variety is the Brown Catechu in conical masses, from Siam. The quantity of Cutch and Gambier imported into Great Britain was last year about 1350 tons.

Mrrobalans. Terminalia Chebula. (Nat. Ord. Combretacece.) (Plate XIII. fig. 68.)

The seeds called commercially Myrabolams are the dried fruit of a small tree, very common in many districts of India and other parts of Asia; it is probable they are derived from more than one species of Terminalia. It is much valued both as a dye-stuff and also as a tanning material. The Myrobalans are about an inch in length, about the size and shape of a Spanish olive, with an olive-yellow-coloured 
pericarp, generally strongly marked with longitudinal wrinkles. They have become a very important item in our commerce with India, but their introduction to general use can only date back about ten years. The imports, according to Mr. Poole, now amount to about 1200 tons annually. 


\section{CHAPTER IX.}

\section{MATERIALS USED IN DYEING.}

"Along the sunny bank, or watery mead, Ten thousand stalks the various blossoms spread.

Peaceful and lowly in their native soil, They neither know to spin or care to toil ; Yet with confess'd magnificence deride Our vile attire, and impotence of pride. The cowslip smiles, in brighter yellow dress'd Than that which veils the nubile virgin's breast;

A fairer red stands blushing on the rose, Than that which on the bridegroom's vestment flows.

Take but the humble lily of the field; And, if our pride will to our reason yield, It must by sure comparison be shown That on the regal seat great David's son,. Array'd in all his robes and types of power, Shines with less glory than that simple flower."

Gongeous as are the colours of flowers, they afford but little assistance to the dyer's art, except in the patterns 



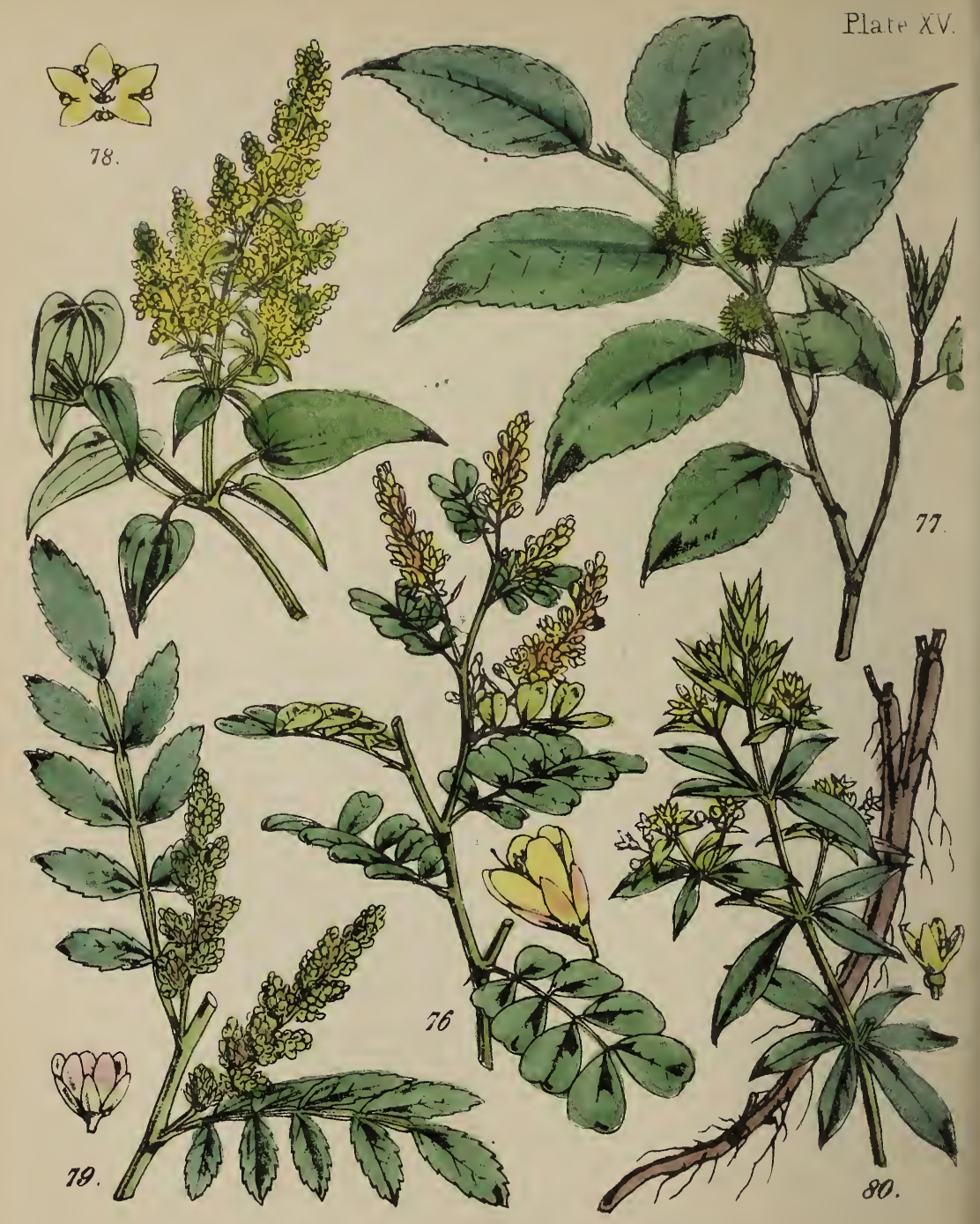

76 Logwwood Tree. 77. Fustic Tree. 78. Munjeet. 79. Sumach 80 . Madder 
which they offer for his imitation. Generally speaking, they are as fugacious as they are brilliant; and those most dazzling to the eyes are often the most ephemeral. The vegetable products which are used in the process of dyeing, are often totally different in colour themselves, to the tints which they yield under the skilful treatment of the dyer. But much as art has done to improve this important branch of our manufactures, we are still very far from rivalling the flowers of the field; and if the "lily of the valley" mentioned in Scripture is, as is very generally supposed, the Lilium Chalcedonicum, not even the rapid advance of the arts and sciences has yet enabled the sovereigns of the earth to say their vestments can rival those of that lily in beauty and brilliancy.

Our vegetable dyes are derived from all the parts of plants: thus the roots of some, the wood of many more, the bark, the leaves, the flowers, and the fruit of others. The first we shall notice is the

Logwood. Hamatoxylon Campechianum. (Nat. Ord. Leguminosa.) (Plate XV. fig. 76.)

The tree producing this dye is a native of the province of Yucatan, in South America, the principal town of which, Campeachy, situated on the river San Francisco, in the Bay 
of Campeachy, was formerly the mart for logwood; but it is now extensively cultivated in Jamaica, and the chief trade is removed to Belize, a British settlement in the Bay of Honduras, whence immense quantities are annually exported. Logwood was introduced into England as a dye in the reign of Queen Elizabeth, but, owing to the ignorance of the dyers in fixing the colour, it fell into such disrepute as to occasion the passing an Act of Parliament, entitled an "Act for abolishing certain deceitful stuffs employed in dyeing cloths ;" this law remained in force, and prohibited the use of logwood, until 1661, when it was repealed.

This Hamatoxylon is a tree reaching fifty feet in height. The wood is very hard and dense, having a greater specific gravity than water; the leaves are very handsome, they are pinnate and of a fine dark glossy green colour; the flowers are pea-shaped, in fine yellow racemes.

The colouring matter depends upon a peculiar principle called hamatin, or hamatoxylin, a red crystalline substance, which is so abundant in some samples as to exist in the form of distinct blood-red crystals. The stems are cut into large logs, and the bark and alburnum, or white wood, is chopped off; the dark-red inner wood being the only valuable portion. 
The colour of a decoction of logwood is of a brownish blood-red. Acids change it to the bright colour of red ink (which is usually made by adding acetic acid to an infusion of logwood chips). The alkalies strike a purple or violet, and the salts of iron a dark violet, approaching a black colour.

The quantity of logwood imported into England in 1851 was 34,090 tons. The value is in proportion to the size of the logs, the largest being the most prized. Latterly, large quantities of the extract of logwood have been imported from time to time.

Nicaragua, Lima, or Peach-wood. Casalpinia echinata. (Nat. Ord. Leguminosa.)

This is sometimes called Brésil de St. Martha. It is in logs about four feet in length, with a diameter of six or eight inches; the whole surface is broken up with deep clefts, giving a very singular appearance to the pieces, which are of a dark reddish-brown colour, the white wood or alburnum being wholly or partly removed; like logwood, the larger the logs, the greater is their value.

It dyes red and peach-colour, and is very extensively used; about 7000 tons are annually imported, chiefly from Rio de la Hache, Mazatlan, Realijo, and Lima. 
Brazil-wood. Ceesalpinia crista. (Nat. Ord. Leguminosce.)

This tree is from fifteen to twenty feet in height, with prickly branches and racemes of yellow flowers. The wood is in much thinner pieces, and of a paler colour than the two preceding dye-woods; it yields rose-colour, red, and yellow, according to the mordants used, but the colours are not permanent, and the wood is less used than formerly, owing to the introduction of superior materials. About 800 tons is now the amount of the annual imports.

Braziletto-wood. Cesalpinia Brasitiensis. (Nat. Ord. Leguminosa.)

The tree which produces this wood is a native of Jamaica, St. Domingo, and probably the South American continent; it rarely attains any great size,-about twenty feet is its maximum height. The foliage is remarkably handsome, each leaf consisting of from six to nine pairs of pinuæ, and each pinna of six to eight pairs of oval, obtuse, oblong, glabrous leaflets, of a very bright, glossy, emerald-green colour, reminding us of the beautiful fronds of some of the ferns of the genus Adiantum. Braziletto is a very useful dye, producing fine red and orange-red colours. The imports amount to about 400 tons per annum. There are 
two varieties, one of which, called the Royal Braziletto, is chiefly consumed in Spain.

Saran-wood, Bookum or BukKum-wood. Casalpinia Sapan. (Nat. Ord. Leguminosa.)

The Sapan-tree is a native of the East Indies; it is as much as forty feet in height, with handsome compound foliage somewhat similar to the last, and handsome racemes of yellow flowers. The branches only are used, and from these the bark is entirely removed before exportation; the pieces are generally about three to four feet in length, and vary from one to three inches in diameter. Sapan-wood yields a good red dye, which however is not easily fixed; nevertheless it is very extensively used both in India and also in Europe; our imports alone were 3670 tons in 1850. The red Telinga cottons are dyed with Sapan-wood.

Sapan-wood root is occasionally imported from Singapore and other places, under the names of Yellow-wood, Sapanwood root, and Sapan root; it imparts a yellow colour. The pieces are usually thin, and about two or three feet in length, with the bark cut off.

CAM-WOod. Baphia nitida. (Nat. Ord. Leguminosce.) This tree is a native of Sierra Leone, with shining imperfectly pinnate leaves, and white or yellow flowers. It is 
of considerable size, often attaining the height of fifty feet. The stem is the part used; it is cut into logs about four feet in length, and these, after the removal of the bark and outer wood, are split and trimmed square for exportation; they are of a rich deep red colour. It yields a brilliant red dye, which is rendered much deeper by sulphate of iron. The red of the English Bandana handkerchiefs is produced by Cam-wood. About 1100 tons are annually imported.

BAR-Woon is the produce of the same tree, and possesses no sensible difference either in quality or appearance; it also comes from the coast of Africa.

Saunders or Red Sandal. Pterocarpus Santalinus. (Nat. Ord. Leguminosa.)

This dye-wood is the produce of a large tree growing to the height of sixty or seventy feet, on the mountains and in other parts of India. It is usually imported in small billets two or three feet in length, of a fine deep red colour; the concentric circles of the transverse section being divided by dark, almost black lines. With different mordants it yields brownish-red, scarlet-red, deep crimson, and yellowishred. 'These colours however are not very permanent. The imports amount to about 350 tons per annum. Another dye-wood, also called Red Sandal-wood, is produced by 
FUSTIC.

Adenanthera pavonina, one of the largest trees of India; the native name is Rukta-chundun. Neither of these must be confounded with the sweet-scented Sandal-woods, which will be described in the chapter on Furniture Woods.

Fustic, Old Fustic. Maclura tinctoria (Plate XV. fig. 77) (Nat. Ord. Moracea), and probably other species of the same genus.

The tree producing this dye-wood is closely allied to the mulberry; it is a native of the West India Islands and the coast of South America. Jamaica, St. Domingo, and Savanilla, are the principal places of export; it is of large size, the logs we receive being about from one foot to two and a half feet in diameter, and from three to four feet in length. The colour of the wood is a fine golden yellow. The French dyers applied the name fustet to a European dye-wood, and from this we have derived the term fustic. The term old fustic is decidedly absurd; it arose from the great error of supposing that the wood of Rhus Cotinus (fustet of the French) was the young branches of the fustic-tree; one however is a mere shrub, native of Europe, the other an immense tree, a native of the New World. Fustic dyes yellow, olive, brown, marone, bronze, and Saxon-green. The quantity imported in 1851 was 9808 tons. 
Young Fustic, or Zante Fustic. Rhus Cotinus. (Nat. Ord. Anacardiacea.) (Plate XV. fig. 79.)

A very ornamental shrub, grown extensively in the Greek Islands, where it is much used for dyeing a beautiful rich yellow colour. It is the same as the Venetian sumach or wild olive. Our imports are chiefly from Patras and Ithaca, and consist of four or five tons with each cargo of currants, for which cargoes the fustic is used as dunnage. Young fustic is in crooked sticks about four or five feet in length, two or three inches in diameter, and of a light sulphuryellow colour, the bark being completely removed. Between 300 and 400 tons are annually imported.

Green Ebony. Jacaranda ovalifolia. (Nat. Ord. Bignoniacea.)

This tree is a native of South America, where it is prized both as a hard wood and a dye-stuff; it is of an olive-green colour, in pieces about three feet in length, and yields olive-green, brown, and yellow colours. About 700 tons are imported annually.

These are the principal woods used in dyeing; several others occasionally come, but owing to the careless manner in which names are applied it is impossible to ascertain their history. A familiar example of this difficulty will be found 
in the history of Fustic, the name being applied to two distinctly different woods, leading to the assumption that they are products of the same tree, but of different ages; whereas one is tropical American, the other European, and they belong to two distinct Natural Orders. In commercial matters many such errors arise, and are fostered for long periods. The remaining dye-stuffs consist of roots, leaves, flowers, and even the entire plant of some species.

Madder Root. Rubia tinctorum. (Nat. Ord. Galiacea.) (Plate XV. fig. 80.)

Madder is one of the most important dyes known. There are several distinct species used, but the European madder is from Rubia tinctorum and probably $R$. peregrina. This plant is extensively cultivated in Southern Europe and in Holland. We receive very large quantities of the root from Smyrna, Trieste, Leghorn, and other Mediterranean ports, packed usually in square bales covered with cloth made of horsehair, or partly wool and horsehair. We also receive great quantities of a less valuable description from Holland, which is generally if not always in powder, under the name of ground madder, packed in very large casks.

The dyeing qualities of the madder-plant were known both to the Greeks and Romans. Dioscorides states that 
it was found both wild and cultivated in Italy and Asia Minor, and, besides being used in dyeing, was also used in medicine under the name of Erythrodanon. Pliny mentions it under the same name, and also calls it Rubia, which is now used for its generic appellation. Leuchs, in his 'Traité complet des Matières Tinctoriales,' says that the Romans also called it Verantia, whence the French have derived their name Grarance. It gives the much-admired Turkeyred colour, also madder-brown and madder-yellow; but it requires nice manipulation to produce bright colours with this material. Formerly the Turks understood the use of madder better than any other people, but lately the art in this country has attained equal if not superior excellence. The cultivation of madder, which occupies a large portion of the agricultural class in Turkey and the Levant, and also in Holland and France, requires much care and labour; the soil requires to be well and deeply worked. The plant is propagated by sets, or suckers from the crown of the root, those taken above ground succeeding best; they are planted in May or June, nine or ten inches apart. The roots are not fit for digging until the third autumn after they are planted. When raised the roots are usually dried in kilns; seasons however occur occasionally when the roots are dried 
on the land by exposure to the sun and air. In commerce we find the following varieties of the common madder:Smyrna, French, Syrian, and Italian roots; and French, Dutch-crop, Ombros, Gamene, and Mull ground madders. The quantity of roots imported in 1851 was 8081 tons, and of ground madder 5012, or both together 13,093 tons.

Garancine.-This substanee is a preparation of madder for which we are indebted to the French. It is powdered madder, acted upon by sulphuric acid; the acid partly carbonizes the lignine, or woody matter of the madder, without impairing the colouring matter, which is consequently yielded with greater ease. Garancine is a valuable but expensive dye; it is in the form of a puce or violet-brown coloured powder. We receive only a few tons annually from France.

East India Madder. Rubia Munjista. (Nat. Ord. Cinchonacea.) (Plate XV. fig. 78.)

This is the article known generally as Munjeet or Munjeeth; it is a native of Nepal, Bengal, and Japan. It grows very much in the same way as common madder; the roots however are thinner and much longer ; they are usually imported in bundles about the thickness of a man's wrist, but flattened by pressure in the bales, and about two feet 
in length. The roots are bent three times, and there are about fifty or sixty in each bundle. Munjeet is often called Chay-root; but this is a mistake, the latter being the produce of a totally different plant. We receive from sixty to eighty tons per annum, all from the East Indies. The uses of this root are the same as common madder.

Снау Rоот.-Under this name two different kinds of root are occasionally imported from India.

1. The true Chay or Che root, which somewhat resembles Munjeet but is rounder and more brittle. It is the root of Oldenlandia umbellata (Nat. Ord. Rubiacea), a native of sandy soils in Java and Coromandel; it is much cultivated in the latter place, where its roots strike very deep in sandy soil. It is used to dye red, purple, and a fine orangebrown. The colouring matter resides entirely in the bark of the root; the inner portion is white and pithy.

2. The roots of several species of Morinda, or Indian Mulberry (Nat. Ord. Rubiacea). They yield a red dye.

Morinda umbellata is a small bushy tree, a native of Ceylon and Malacca; the thinnest roots yield a bright red dye. This is the Mangkudu root of Malacca.

Morinda tinctoria, the Ach root of Central India, is a very short tree, with a large bushy head supported on a 
TURMERIC.

trunk only a few feet in height. The wood is very hard and durable, and in high esteem for gun-stocks. The bark of the roots yields a red dye, which is rather fugitive; the natives use alum to fix the colour.

Morinda citrifolia, a small tree, native of Central India, where its roots constitute the red dye called al or aal; it is used in giving a permanent red colour to the native cotton. cloth called khurwa, which is much worn by the watercarriers of India. These Morindas have all been occasionally imported under the names of Madder, Munjeet, and Chay-root.

TURMERIC. - The rhizome or root. stalk of Curcuma longa. (Nat. Ord. Zingiberacea. See p. 77.) (Plate XIII. fig. 65.)

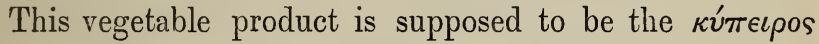

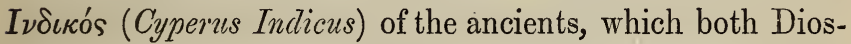
corides and Pliny describe as resembling the roots of ginger in form, but dyeing saliva a saffron-colour when chewed. The name Curcuma is derived from the Persian kurkum, saffron. In India it is known under various names, as Aruk ool Sufr huldee, Jaola huldee, Huldee, etc.

Dr. Pereira describes and figures five different varieties of Turmeric as those which generally find their way into the European markets. 
1. China Turmeric.-This sort consists of smooth, plump, round, and long tubers, of a greenish-yellow colour externally. They yield a bright powder, and on that account fetch a high price, and are much esteemed.

2. Bengal Turmeric.-This consists principally of long thin tubers, externally smooth and of a dull stone-colour; internally a deep reddish-yellow colour, and rather brittle, with shining fracture. It is not so fine in appearance as other sorts, but fetches a high price, and is particularly valuable as a yellow dye.

3. Madras Turmeric.-This Dr. Pereira calls " the most showy of all kinds of Turmeric." The tubers are large; some are long with side branches, others are round and oval; externally they are, in common with the preceding varieties, marked at slight distances by transverse ridges, but besides these the Madras variety has slight longitudinal wrinkles. Externally the colour is bright yellow, internally it resembles that exhibited by the fracture of Gamboge.

4. Malabar or Bombay Turmeric-consists of long irregularly shaped tubers, darkish yellow, and much wrinkled externally; the tubers are smaller than the Madras kind, and of an inferior quality.

5. Java Turmeric-somewhat resembles the Chinese va- 
riety ; consisting also of short and long tubers, chiefly long, and of a greenish-yellow colour. It is not common in the markets.

The colours produced by turmeric are various very beautiful shades of yellow, but, like many others of our most beautiful dyes, the colour is not so permanent as conld be desired. Besides its use in dyeing, turmeric forms a principal ingredient in the favourite Indian condiment currypowder. The quantity imported from India and China in 1851 was about 2000 tons.

Querctiron BarK. Quercus tinctoria. (Nat. Ord. Corylacea.)

The Quercitron Oak is a large tree, a native of North America; the timber is valuable for ship-building purposes, and the bark is largely used for tanning leather, but in this country it is used for dyeing yellow. For this purpose the underbark is crushed, and resembles a mass of short yellowish-white fibres, mixed with powdery particles; in this state it is packed into very large hogsheads, and exported to Europe. Between 3000 and 4.000 tons are consumed annually in England.

Flavine.-Under this name a new dye-stuff has lately been imported from the United States. A sample of the 
first importation was exhibited in the Liverpool collection of raw produce, at the Great Industrial Exhibition; it was presented by T. B. Blackburne, Esq., merchant, of Liverpool. From an examination of that specimen, and some lots subsequently imported, besides information from other sources, the author is induced to believe that it is a precipitate of colouring matter from the Quercitron bark, formed in the tan-pits of the American tanners, who endeavour to keep its manufacture secret. It is a greenish-yellow powder, and is said to give a fine olive-yellow colour to cloth. About 170 tons have been imported during the last two years.

SAFFLOWER.-The dried flowers of Carthamus tinctorius (Plate XIV. fig. 71) (Nat. Ord. Composita) pressed into little cakes. (Plate XIV. fig. 72.)

The Carthamus is an annual plant, which has bright yellow composite flowers, somewhat similar to marigolds, about as large as a crown-piece in circumference. The florets are plucked out, pressed into small cakes, which are dried and packed into bales, weighing about two hundredweight each. Safflower is used for three different purposes; first, for adulterating the more valuable article saffron, this however is a very insignificant application; secondly, it is largely consumed in the manufacture of rouge, and gives 

happiness to the heart of many a faded belle, who, selfdeceived, believes she has hidden the ravages of time beneath its friendly mask; and thirdly, in dyeing. Two colouring principles exist in Safflower : one is soluble in water, and is a bright saffron yellow colour; the other, which has been called carthamic acid and carthamin, is soluble in alkaline solutions, and is of a fine rose-red colour : this latter, when precipitated from its solution, dried, and mixed with very finely powdered talc, constitutes rouge. Properly prepared, the red colouring-matter communicates a beautiful red colour to silks, but is very fugitive, and will not bear washing. The quantity of safflower imported is considerable. The greater portion comes from the East Indies; this is always pressed into the little cakes before mentioned. A small quantity has latterly come from Egypt, of very fine quality, not pressed, but loose, like saffron, which it very much resembles. The imports into the United Kingdom in 1851 were nearly 600 tons.

Safrron. - The dried pistils of the common Crocus. (Crocus sativus: Nat. Ord. Iridacece.)

Though affording a brilliant yellow colour, more easily perhaps than any other vegetable product, saffron can hardly, in the common acceptation of the term, be considered a dye- 
stuff in this country. It is however much used as a colouring ingredient in food and medicine, and many medicinal virtues have been attributed to it, both by the ancients and moderns. It is of very ancient repute, being first mentioned by Solomon in his "Song," chap. iv. ver. 14: "Spikenard and saffron; calamus and cinnamon, with all trees of frankincense ; myrrh and aloes, with all the chief spices." Homer alludes to it in the Iliad; and that it was familiarly known to the Romans is evidenced by the frequent allusions we find in their classical writings to this substance. Thus its medicinal properties are alluded to when Propertius says, "Et crocino nares myrrheus ungat onyx;" and $\mathrm{Ca}$ tullus alludes to the dyeing quality, and speaks of saffroncoloured tunics, "tunica crocina." Virgil very often alludes to it; once he says, "Circumtextum croceo velamen acantho." Our English word Saffron is derived from the Arabians, who called it Zafaran.

Formerly, saffron was extensively cultivated in England, especially in Essex : the name of the town Saffron Walden arose from that place being one of the chief marts for this article.

The common crocus is a native of Asia Minor, but it has become naturalized over most parts of Europe, and in this 



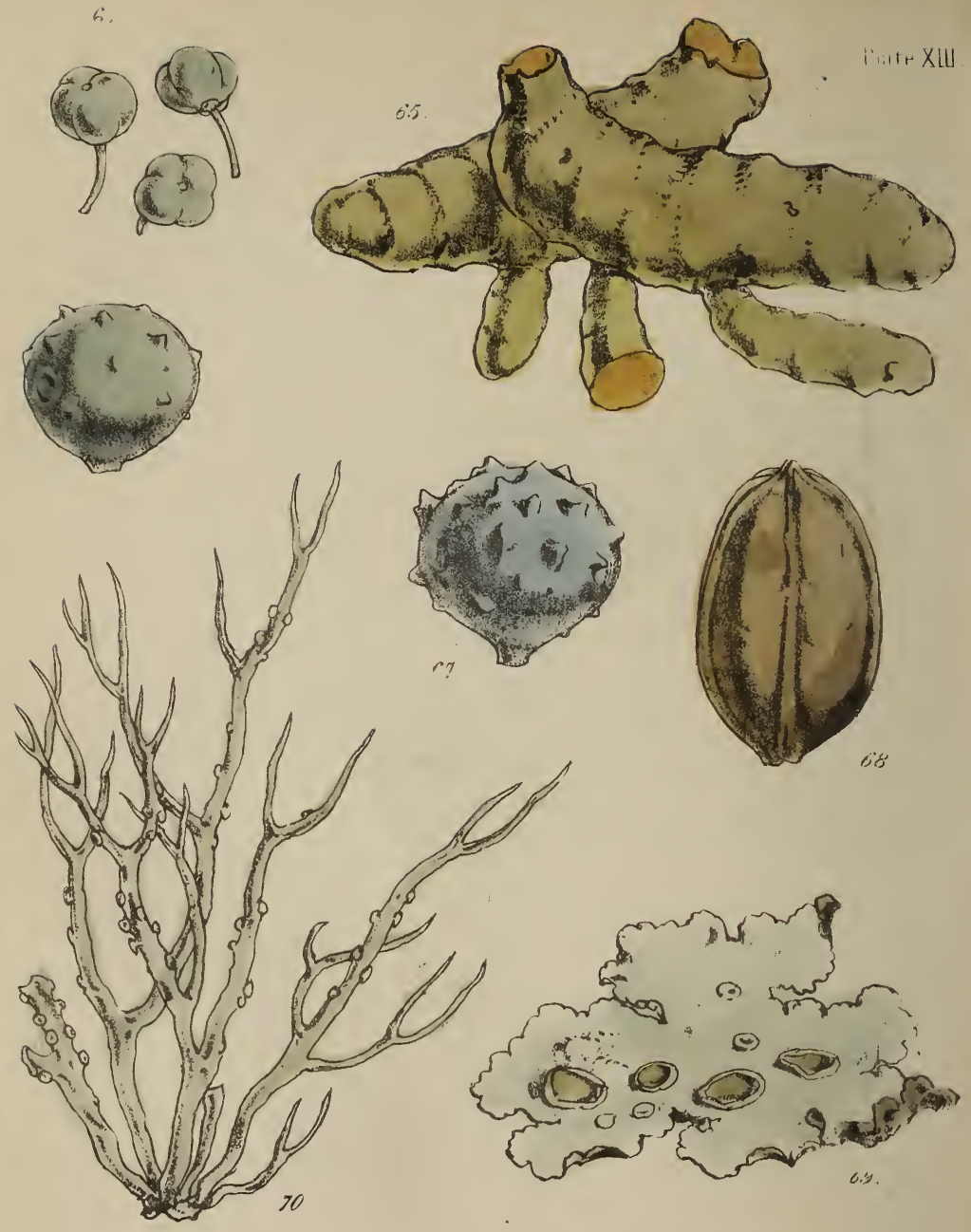

64. Persian Yellow Rerries. 65. Turmeric fiti. Whil " lialls

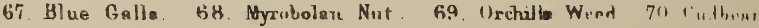


country has given rise to a great number of varieties, which are esteemed only as garden flowers.

There are two kinds of saffron imported, the Spanish and the French; formerly an inferior kind was in use, called Cake Saffron, which was in flat cakes made by mixing it with gum and rolling it into thin oval cakes about the size of the hand. From 5000 to 7000 pounds only are annually imported; and this is chiefly used in pharmacy, the dyeing property being inferior in permanency to that of other preferable materials.

Yellow Berries.-The berries of Rhamnus infectorius. (Nat. Ord. Rhamnacee.) (Plate XIII. fig. 64.)

The Buckthorn, which produces the berries called yellow berries, and sometimes Persian berries, is a native of the South of Europe, where it is much cultivated. It is a procumbent shrub, growing naturally in rough rocky places; in the Levant it forms an important article of commerce, and in France it is also extensively cultivated. The unripe berries are gathered and dried; those from Smyrna and other places in the Levant are the best; those from France are smaller and are not much used in this country,-they are called Avignon berries, or Grains d'Avignon.

Yellow-berries produce a beautiful yellow colour, which 
however is giving way to the mineral colours, in consequence of its want of permanency-the fault of most vegetable colours. The consumption is still very considerable, amounting to between 500 and 600 tons per annum.

Shumac or Sumach.-The dried and powdered leaves of Rhus Cotinus. (Nat. Ord. Anacardiacea.) (Plate XV. fig. 79.) This material was known to the ancients, by whom it was used for tanning as well as dyeing. It contains large quantities of tannin, as well as a yellow colouring matter similar to that yielded by fustic; the wood of this plant has been already described as young fustic. It is brought to this country in small bags, of about one hundredweight and a half. More than 13,000 tons were imported in 1852.

Orchella-weed.-Under this name are imported several species of Roccella. (Nat. Ord. Lichenes.)

The lichens which constitute the Orchella-weeds of commerce are of an ash-grey colour, and consist of long thin flat thalli, or leaves, having a mealy appearance; they are about an inch and a half to two inches in length, and much branched.

The ancients were acquainted with one or more of the 
species. Pliny alludes to it under the name of fucus marinus, but he also applied the term fucus to the alkanet or red-herb used in dyeing, and from which the rouge, with which "vetulæ vitia corporis fuco occulunt," was made. He applies the term fucus also to the juice of the purplefish, a gasteropodous mollusc, of the genus Murex, from which the ancients are said to have made the beautiful Tyrian purple. In his 'Dictionnaire Classique d'Histoire Naturelle' Bory de St. Vincent gives his opinion that the purple dye of the ancients was prepared from the rocklichen (Roccella), and not from Murex; as both are found upon or near the sea-shore there is some probability of its truth. It would be an interesting investigation, to ascertain whether the purple secretions of many molluscs be not derived from the vegetable food they gather from the shore; there is one point however which almost prevents the supposition that they feed upon the Roccella, because it grows upon the $d r y$ rocks; but it is not impossible that some of the marine Algce and Fucoidece may yield the same colouring principles. Should this be the case, Bory de St. Vincent may be right, and we shall not have the interesting legend destroyed which describes the discovery of the Tyrian purple. This legend states that Hercules made a journey 
along the sea-shore, to visit his ladye-love, who, it appears, was both capricious and imperious; his dog accompanied him, but, being more engaged with thoughts of his stomach than his heart, the animal sought food from the sea-shells which strewed the shore. The lady, with true feminine quickness, noticed that the mouth of the dog was stained with a rich deep purple, the value of which she at once perceived; she therefore dismissed her lover in search of this purple dye, telling him not to approach her again until he had procured her a robe of the identical colour which had excited her admiration. Poor Hercules, who had conquered more difficulties than most men, was nearly beaten by this "labour" of love. After much search, he despaired of finding the means of dyeing a robe for his mistress like his dog's mouth; and was very dejectedly trudging along the same road as before, to plead his almost hopeless case to the exacting fair one. His companion, the dog, accompanied him as usual, and having made so profitable an excursion on the previous occasion, he employed his time in a similar indulgence of his taste for shell-fish. To the master's surprise, he again saw the animal had acquired a blue nose; he retraced his steps, watched the actions of the dog, and saw him feed upon that Murex whence the dye is supposed 
ORCHELLA.

to have been obtained. The animals were collected, the robe dyed, and this "labour of Hercules" was accomplished.

The strongest argument in favour of the ancient purple of Tyre being derived from the Roccella, is the following passage from the Old Testament, which would seem to infer that it was collected on the rocks :-

"Fine linen, with broidered work from Egypt, was that which thou spreadest forth to be thy sail; blue and purple from the isles of Elishah was that which covered thee."Ezekiel xxvii. 7.

The art of dyeing with these lichens, lost during the dark ages, was not revived until the fourteenth century, when it was accidentally discovered, and afterwards practised at Florence by a gentleman of birth named Ferro or Fredrigo, who from this source derived a princely fortune, and founded a family, which from this circumstance bore the name of Oricellarii.

The Orchella-weed of commerce is brought from various places, each supplying a distinct species, which commercially bears the name of the locality. The following valuable list from Pereira gives the botanical names:- 


\begin{tabular}{|c|c|c|c|c|}
\hline Angola . & . & • & - & - Roccella fuciformis. \\
\hline Madagascar & • & - & . & - R. fuciformis. \\
\hline Mauritius & • & - & - & ? ? \\
\hline Canary . & • & . & . & - R. tinctoria. \\
\hline Cape de Verd & • & • & • & - R. tinctoria. \\
\hline Azores . & & 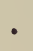 & - & - R. tinctoria. \\
\hline Madeira & $\cdot$ & . & . & - R.tinctoria\&fuciformis. \\
\hline
\end{tabular}

South American, large and round $R$. tinctoria.

99

Cape of Good Hope .

Barbary (Mogadore)

Corsican and Sardinian small and flat . $R$. fuciformis.

- R. hypomecha.

- R. tinctoria.

- R. tinctoria.

The Angola and Lima sorts constitute the bulk of the Orchella-weed imported; it therefore consists principally of R. tinctoria (Plate XIII. fig. 69). The colouring matter of these lichens varies slightly; that of the Angola weed is the best, and consists of a peculiar vegetable acid called erythric; orsellic acid, of the variety alpha (there being two sorts), constitutes that of the Lima weed.

The article known in commerce under the names Archil and Orchil is the colouring matter of Orchella-weed in solution; it is used for dyeing purple and red. It does not produce a fast colour, but so greatly improves other 
colours, as to be considered indispensable by the dyers; nevertheless its consumption has very much decreased of late. The imports are about 600 tons per annum.

Rock Moss.-Under this name we have occasional imports of another lichen, Lecanora tartarea (Plate XIII. fig. 70). It is used to make the article called Cudbear, which is employed in the same way as archil. Cudbear however, besides being in the liquid form, is dried and made into cakes, called cudbear paste; and is also preserved by dipping linen rags to absorb the colour; these are then dried, and form a considerable article of commerce.

Tisso Flowers. - The dried flowers of Butea frondosa. (Nat. Ord. Leguminosa.)

These flowers are much used in the East Indies to produce beautiful orange and yellow dyes, and the author has seen one importation into Liverpool, consisting of a small parcel introduced experimentally under the name of Kessaree flowers.

Myrobalans (commercially Myrabolams). - The dried fruit of Terminalia Chebula. (Nat. Ord, Combretacea.) (Plate XIII. fig. 68.)

The Myrobalan is an oval fruit of the shape of a nutmeg, but generally twice as large; they are of a dingy yellow 
colour and hard glossy exterior ; the pericarp is rather soft, but the interior albumen is very hard, and contains a large quantity of tannin; hence it is useful to the tanner as well as the dyer, both of whom use large quantities of this product. The surface of the fruit has slight longitudinal depressions, which do not appear on the larger myrobalans. The smaller ones, besides this characteristic, are pointed at each extremity, which makes it probable that more than one species is imported in the same lot.

With alum this dye yields a good durable yellow, and with salts of iron a black colour little inferior to that produced by oak-galls. The myrobalan has not been introduced more than ten or eleven years, but so useful has it been found, that it has become a very important article in our produce markets, and its consumption is now fully 2000 tons per annum.

Galls, GALL-Nuts, OAK-GALLS, and Nut-GaLLS, are excrescences formed upon the young twigs of the various species of oak. Galls are also produced upon other plants, but the nut-galls of commerce are produced on the species of oak called Quercus infectorius, a small shrub about five or six feet in height. They originate in the puncture of an insect, Cynips galla-tinctoria. The puncture is effected 
by the ovipositor of the insect, and an egg is at the same time deposited; an interruption in the ordinary functions of the tissues of the plant takes place at the spot where the egg is inserted; the consequence is, an excrescence of vegetable matter, principally tannin, is formed round the egg, and furnishes a nidus for the grub or larva when hatched. When this takes place, the grub eats its way out through the side of the gall, after which the vitality of the excrescence either decreases or ceases altogether.

Several varieties of galls are distinguished in commerce, the principal of which are the blue and white; the only difference is that the former are gathered before the insect has escaped, and the latter after it has emerged. The colour of the blue galls (Plate XIII. fig. 66) is a slaty-blue, and sometimes a greyish-green; the white gall (Plate XIII. fig. 67) is of a light drab colour and much lighter in weight; it is also less valuable than the blue variety. Nut-galls are nearly round, with a few small excrescences over their surface. They yield a fine black colour, with any of the salts of iron, and are used in the preparation of writing-ink; the quantity imported is annually about 700 tons.

A kind of gall has lately been imported from China; Dr. 
Pereira describes it in the Pharmaceutical Juurnal, vol. iii., under the name of Woo-pei-tze ; they are of a very irregular shape, more bulky than the common galls, and hollow, the external shell being only about $\frac{1}{32}$ of an inch in thickness, very brittle, and of a brownish-yellow colour. $\mathrm{Mr}$. Doubleday says the producing insect in this case is one of the Aphis tribe; they are extremely astringent, but have probably not yet been used in dyeing. The two next dyestuffs are vegetable extracts.

Ariotio, Anatтo, Anotтa.-The pulp extracted from the seeds of Bixa Orellana. (Nat. Ord. Flacourtiacea.)

The seeds of the Bixa are enclosed in a three-valved seedvessel, about an inch in length, and somewhat like the capsule of the common beech; it is covered with short hair-like prickles, and is of a rich dark brown colour. When the valves open, the seeds, ten or twelve in number, are seen packed within; they are about the size of tares, but rather angular, and, being covered with a waxen pulp of a bright orange-colour, are not unlike coral beads. This waxen pulp is removed from the seeds by washing, and forms the anatto of commerce, which usually is of a yellowish-red colour, and about the consistency of palm-oil ; this is flag and roll anatto. It is sometimes in a drier state, made into cakes, 
and termed cake anatto. It gives a fine yellow, and also the nankeen colour, and is much used for colouring cheese. The imports are variable; in 1847, 138 tons were received, and in 1850 only 72 tons.

Indrgo (Plate XIV. fig. 74). - A peculiar vegetable colour, extracted from Indigofera tinctoria (Plate XIV. fig. 73) and several other species of the same genus (Nat. Ord. Leguminosa). Various other plants also yield indigo, but they do not furnish any portion of that consumed in this country.

This important material was known to the ancients, who used it both as a dye and also as a paint. Dioscorides

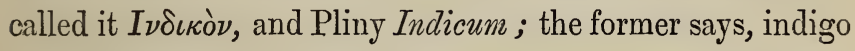
comes from the workshops of the dyers, attaching itself to the vessels from which it is removed and dried. Pliny speaks of another kind which is formed spontaneously like a froth upon Indian reeds: the author is of opinion that the article here alluded to is the lac dye, now so extensively used.

Like many other valuable discoveries of the ancients, the use of the indigo was losi to Europe until the middle of the sixteenth century. It was introduced by the Dutch, who imported it from India, but its use was almost pre- 
vented by a strong prejudice which existed against it for a considerable time. In the reign of Queen Elizabeth an edict was passed prohibiting the use of this dye, which was called food for the devil, and this edict was not withdrawn until the reign of Charles II. Its use was also prohibited, or restricted, in Saxony and France. The prejudice against the use of indigo seems to have arisen from the ignorance of the dyers as to the means of fixing the colour, so that the cloths, however beautiful to the eye when new, became disfigured immediately they were wetted. Since however its value became known, its culture, previously confined to its native country, India, has spread into the West Indies, Mexico, Brazil, Egypt, and other suitable places.

It does not exist as indigo in the plant, but when the plant is subjected to a certain process, the blue colour is educed. The largest quantity is yielded from the plants when in flower, but the finer qualities are produced when the flowering has ceased. The process of separating indigo from the plant was first accurately described by Jean Baptiste Labat, a Dominican missionary monk; it is as follows.

Just before flowering, the plants are cut down and tied into bundles about five feet in circumference; these are 
quickly carried to the factory, allowing no time for the plants to flag and become heated, as the slightest degree of fermentation destroys the indigo.

These bundles are placed in a vat and tightly pressed down by superincumbent weights. Clean water is then admitted, sufficient to cover the whole. After steeping from nine to twelve hours, the liquid, which has acquired a yellow colour, is drawn off by removing a plug from the bottom of the vat. This liquid is received into another vat, where it is kept actively stirred and beaten about with bamboos until a curious granulation takes place; when this has become complete, the granulations settle and the mother-liquor is drawn off. The blue precipitate is then washed with water, and submitted to heat until it appears to effervesce, or ferment, as the planters term it. It is then placed in frames, and submitted to extreme pressure, after which it is cut into cakes about two inches square, dried, and packed into boxes for exportation.

The Indigo plant is a shrub from two to three feet high, with pinnate leaves, consisting of from four to seven pairs of leaflets, which are of an obovate form (that is, oval, with the broadest part at the top). The leaves are of a dull bluish-green colour on the upper surface, and slightly pu- 
bescent or hairy below ; the young stems have the same peculiar indigo-green tint. The flowers are pea-shaped, borne in short racemes, springing from the axils of the leaves; they are a pale rose or red colour. Besides Indigofera tinctoria, I. Anil and I. carulea are much used in the manufacture of indigo; according to Roxburgh, that from the last-mentioned plant is the best. Owing to the insolubility of indigo in water, the art of dyeing with it consists in a very complicated process, so purely technical that it would be out of place in a popular work like the present. The fine Saxon blue cloths are dyed with this material.

The principal varieties recognized in commerce areBengal; Oude; Manilla; Madras; Caraccas; Spanish Floras; Spanish Sobres; and Spanish Cortes. The average price is about three shillings per pound. The enormous quantity of 3524 tons of this vegetable extract was imported in 1851, but of this quantity more than one-half was sold to foreign merchants and re-exported to other countries.

The colouring matter of Woad (Isatis tinctoria), used by the ancient Britons, was analogous to indigo.

LAC DYE in many respects resembles indigo, but, being partly an animal product (a secretion of the Lac insect, Coccus lacca), further notice of it would be out of place in this work. 
The substances remaining to be treated of in this chapter are not strictly dye-stuffs, but as their chief use is for colouring other materials, they will be most in place if classed with dyes.

Alkanet Root. Anchusa tinctoria. (Nat. Ord. Bora ginacea.)

The Anchusa is a weedy, diffuse plant, rarely attaining a foot in height; it however forms long woody roots, which contain the colouring principle. It is much cultivated in the south of France and some portions of Germany. Its chief use is in giving a fine crimson colour to oils used in perfumery, and in dyeing wood in imitation of rosewood. For this purpose the colour is separated by soaking the root in oil, and the wood is rubbed with the coloured oil until it is rendered sufficiently dark. About eight to ten tons are annually imported, chiefly from France and Germany.

Dragon's Blood.-Under this name several resins are found in commerce, which have a similar appearance, that is, a fine dark cinnabar or Indian-red colour, resinous lustre, and are inodorous and tasteless. They are produced by one or two species of Calamus, or cane-palm, and are used for colouring varnishes and particularly for dyeing horn so as to imitate tortoiseshell. 
The commercial varieties are distinguished according to the form in which they are imported. They are thus named :

1. Dragon's blood in the reed, or Stick Dragon's Blood; in sticks about eighteen inches in length, wrapped in a piece of palm-leaf and bound with very thin strips of rattan cane. It is supposed to be produced from the berries of Calamus draco.

2. Dragon's Blood in drops or beads.-This variety is in small pieces about the size and shape of a nutmeg; a number of these are laid lengthwise in a strip of palm-leaf, which is rolled round them, they are then tied with a string between each mass, so that the whole resembles a string of beads. We have the authority of Rumphius for stating that this also is procured from the fruit of $C$. draco.

3. Dragon's Blood in tears. - This occurs in loose rounded lumps, varying in size from a pea to a swan's egg, and there is some reason for believing that it is furnished by the fruit of Calamus Rotang (Plate VIII. fig. 39).

4. Dragon's blood in lump.-A very inferior article, which is probably the refuse of the more carefully prepared sorts kneaded in masses, which afterwards are broken into the irregularly shaped pieces in which we receive it. 
The quantity imported of all the varieties is but small, and usually comes from the East Indies; it is produced chiefly in the Indian Archipelago. There are two or three similar secretions called Dragon's Blood, but these are rarely met with. One is produced from the curious Dragontree, Dracena draco, a plant of the same order as the lilies (Litiacea); another from the Pterocarpus draco, a papilionaceous tree, allied to that producing the red saunders-wood above described. The imports in 1850 were 117 packages, or about six tons.

Gamboge.-A gummy and slightly resinous exudation from the young wood of the Gamboge-tree (Hebradendron cambogioides, Nat. Ord. Clusiacea). (Plate XIV. fig. 75.)

Though decidedly not a dye-stuff, this material is much used in colouring, forming a valuable water-colour; and is also used in colouring lacquer varnish for brass-work. There is some reason to believe that gamboge is made from more than one species. It was first introduced to Europe in 1603, by Admiral Van Neck, who brought it from China under its eastern name of Ghittaiemou.

There are three kinds of gamboge :-

1. Pipe Gamboge, which is the best; it comes from Siam in rolls about an inch and a half in diameter and sometimes 
a foot in length, through which there is a hole half an inch in diameter. It has been conjectured that this is from Garcinia Cochinchinensis.

2. Lump Gamboge, in masses, having the appearance of a hardened yellow paste in lumps of one or two pounds' weight; this is known to be produced from Hebradendron cambogioides.

3. Gamboge in Tears. -This is in drops called tears, said to be produced from the same species as the last, but the truth of this is much disputed.

Besides its use as a colouring material, gamboge is much used in medicine as a drastic purgative.

We now take leave of the articles employed in tanning and dyeing; but before we proceed further it would be well to take a retrospective glance at the materials which have been described.

Rough and unattractive to the eye, they nevertheless afford the means of rendering more durable and beautiful those materials of which our useful and decorative apparel is manufactured. Crude and unpromising they all are to the uninitiated eye, and their value is only shown when the inventive genius of man is brought to bear upon them. 
Man protects his feet from cold and other injuries with the skins of beasts : in this he follows the example of his most remote ancestors; but, unlike them, his taste is more refined, and the multiplicity of his demands renders economy necessary; he therefore taxes the giant oak, the acacia, the mangrove, and other vegetables, to furnish him a chemical agent whereby the offensiveness of the skins he uses is destroyed, and their tendency to decay arrested. He wears his garments of hemp, flax, and cotton, and strives to rival the flowers of the field by fixing their tints on his fabrics : in this he fails, - these colours are as evanescent as the flowers that yielded them. His thinking mind is taxed to remedy the evil, and triumphant intellect leads him forth and points out more suitable materials; he collects them, and adapts them to his purpose.

Could an intelligent mind look with one eye upon any of the glittering pageants of the fashionable world, and with the other upon a store of dye-stuffs, what strange reflections would arise! Could it be imagined that all those brilliant colours were derived from such a source?-that those warm and bright tints of red, crimson, and purple, rivalling the rainbow, were derived from the ugly piles of gnarled billets and blocks of Casalpinias, etc., cut with 
immense labour in tropical forests and transported at immense cost to our shores? Look again at the dingy madder, munjeet, and yellow-berries, and who could imagine that the bright charming colours produced to please the eye of taste are drawn from such sources? Once more, look at the rock-weed, without an appearance of colour beyond a dirty drab tint, yielding nevertheless a purple fit for the adornment of princes. How true it is that industry works its own reward, and that the Creator has given to man an inexhaustible treasury from which he may draw all that his wants and luxuries require; exacting only in return-labour-as the penalty of the first trans. gression. 


\section{CHAPTER X.}

GUMS USED IN THE ARTS.

THe term Gum is applied to a variety of articles extremely different in character; properly speaking it applies only to those natural exudations which, when solidified by drying, are capable of being redissolved by water. They are often transparent, and are more or less coloured, the tint varying from white to reddish-brown.

When insoluble in water, but soluble in alcohol, they bear the name of Gum-resins; and if soluble in oil or spirit of turpentine they are Resins. Besides these, under the same chapter we must describe the elastic gum, India-rubber, and the anomalous product Gutta-percha.

Of the true Gums there are but a few sorts found in commerce; they may be all comprised under three heads- 
Gum Arabic, Gum Senegal, and Gum Tragacanth. The first,

Gum Arabic, exudes from Acacia Arabica (Nat. Ord. Leguminosa) and other species.

The trees producing the varieties of this gum are abundant in the East Indies, Egypt, Arabia, and Senegal. The gum was well known to the ancients, and the acacia-tree is supposed to be the Shittah and Shittim-tree spoken of in Scripture (Isaiah xii. 19, Exodus, Leviticus, and other books). Most of the species of Acacia growing in warm countries produce gum, and the different qualities of gum are produced on the same species; indeed gum arabic appears to be a special product of the genus Acacia, and the gum oozes out more or less pure from the same tree, and from different species indiscriminately. It is gathered without reference to quality, and afterwards sorted. Of that called gum arabic, par excellence, there are three leading sorts,- 'Elect,' or the finest white gum; the common gum arabic, which is yellow and reddish; and gum siftings, which consist of the very small particles of both the other sorts separated from the finer pieces by sifting.

The following are the permanent varieties which are recognized in commerce :- 


\section{African Gums :-}

1. Gum Arabic,-produced chiefly from Acacia vera and Acacia Arabica. The 'Elect' and 'Common' sorts are in tears, or hardened drops, varying in size from a pea to that of a pigeon's egg, and in colour from a dull white to dark amber. Imported principally from Barbary and Turkey.

2. Barbary Gum.-This is uniformly a dark-coloured variety, resembling the common gum arabic; it is much valued by confectioners for various purposes. It also comes from Northern Africa, chiefly from Mogadore. Supposed to be produced by $A$. gummifera .

3. Gum Gedda.-A reddish variety of Barbary gum.

4. Gum Senegal,-produced partly by $A$. Senegal and partly by $A$. Seyal. This gum is in fine large roundish tears, or, occasionally, worm-like masses ; the largest round tears are the size of pigeons' eggs, clear and transparent, with sometimes a slight pink tinge discernible. The external surface is dull and slightly wrinkled from drying, but internally this gum is very clear and transparent; it is much prized by the manufacturers for dressing silks, crapes, etc., and realizes high prices. It originally came only from Senegal, whence its name, but it is now found at most of the African ports from Senegal to the Cape of Good Hope. 


\section{Indian Gums :--}

5. Wast India Gum,-a very dark variety, seldom lighter in colour than the darkest pieses of Barbary gum. It is generally supposed to be produced by $A$. Arabica; but it has been suggested that it is the produce of a totally different plant, Feronia elephantum, a plant of the Orange tribe (Aurantiacece).

6. Gum Babool,-an inferior variety of the above. This gum is in very irregularly shaped pieces, appearing to consist of a number of small round tears joined together; its colour is very dark reddish-brown; it is tough and cannot easily be powdered. It is from Bengal.

7. Gum Gattie, - a finer gum than either of the above, produced by the $A$. Arabica, in the Deccan, Concan, and Guzerat. It is largely imported into London.

8. Gum Oomrawattee, -another variety, of very indifferent quality, from the province of Oomrawattee.

All the East Indian gums are dark-coloured and translucent; they are tough, and strongly resemble the gum which oozes from the cherry-trees of this country.

The gums described are compounds of the two principles arabin and bassorin. The former is easily soluble in cold water; the latter is softened and swells in cold water, which 
GUM TRAGACANTH.

it absorbs largely, but is insoluble; the finest qualities contain more of the former, and the inferior more of the latter principle.

The quantity imported of all of the above kinds of gum is very considerable; in 1850,1984 tons, of which 328 tons were Gum Senegal. These gums are chiefly used by the manufacturers of silks, crapes, muslins, etc., for the purpose of stiffening and glazing their fabrics; there are besides various other economic purposes to which they are applied. Gum arabic is said to be so nutritious as food, that the Arabs who gather this gum almost support themselves with it during the harvest.

Gum Tragacanth, or Gum Dragon. - An exudation from the stems of two or three species of Astragalus, another genus of the Natural Order Leguminosce.

Tragacanth was known to the ancients, and was by them

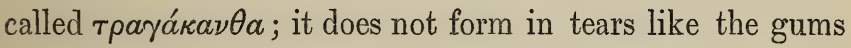
previously described, but forms in flakes, which have the appearance of paste forced through narrow splits in the bark. It is white and opake, and the flakes have a curled and twisted appearance.

The best tragacanth is said, upon good authority, to be the produce of Astragalus gummifer, a native of Koordistan; 
it is quite white and free from impurities. The ordinary kinds, which we receive from Turkey, are produced in Asia Minor and Northern Persia by the A. verus; and the inferior kinds, which are less flaky, being often in wormshaped fragments and irregular tears, and generally of a ferruginous colour, are produced by $A$. strobiliferus.

These plants are small shrubs, with clusters of small yellow pea-shaped flowers; they are either terminal (that is, growing at the ends of the branches), or produced in the axils of the leaves (axillary), which are pinnate, with five or six leaflets; the branches are covered with the remains of the petioles of the leaves, which gives them a rough spiny appearance.

The singular appearance the flakes of this gum present, has been explained by De Candolle as the result of a peculiar property, possessed by some portions of the stem more than others, of absorbing moisture from the atmosphere; this property is termed hygrometric. It acts thus:The tragacanth is a natural secretion of the plant, which is formed by the bark and albumen; it consists of arabin, the soluble principle of gum, and a large quantity of the insoluble principle, called bassorin. In the damp state of the atmosphere, which is often produced by the heavy mists 
which hang upon the hills where the Astragalus grows, the highly absorbent wood takes in the moisture so as to swell considerably, thereby exercising a great degree of pressure upon the bark, which does not give way in proportion to the swelling of the wood, in consequence of which its fluid contents are pressed out, and solidify by drying.

Tragacanth is much valued by our manufacturers of crape: its stiffening qualities are very superior, both the brittleness and glossiness of the Acacia gums being absent in tragacanth. The supply is very limited, the imports rarely exceeding 30 tons per annum.

Gum Kuteera, produced by Sterculia urens (Nat. Ord. Sterculiacea), resembles Tragacanth, and has been imported to this country from Coromandel and used as a substitute; it was formerly much used, but has lately become rare.

Sierra Leone Tragacanth is the produce of another species of Sterculia, S. Tragacantha; it is named thus from the strong resemblance of its exudation to the genuine tragacanth. It is rarely imported.

Gum Bassora.-This, as its name implies, is received from Bassora ; it consists chiefly of the principle bassorin, to which its name has been given. It is in irregularly shaped 
pieces, variable in size, opake, and generally of a light sherry-brown colour. It has been conjectured that a species of Mesembryanthemum yields this gum, but most probably this is an error; we are however totally ignorant of its origin. It is only an occasional import.

The Gum-resins and Resins used in the arts are not very numerous, and one of them (Dragon's Blood) has already been described in the previous chapter; the principal are-

CopaL, which is of various kinds, yielded by different trees in Africa and South America, the East Indies, and Australia.

Brazilian Copal is produced by plants of the Natural Order Leguminosa, chiefly by some species of Hymencea, and by Trachylobium MLartianum. It is in large angular pieces, often as large as a hen's egg, very transparent, and of a light yellow colour.

African Copal is also in large fragments of rounded tears, or masses; it is darker in colour than that from Brazil, and less transparent, often having a reddish-yellow colour and dusty surface. It is supposed to be produced from a species of Hymenca; but there are evidently different sorts of African Copal. 
East Indian Copal, more generally called Gum Anime, is supposed to be the produce of Hymencea Courbaril. It is in large-sized pieces, often almost square, and long; some specimens in the Author's collection are about four inches in length, and as regular in shape as a square stick of sealing-wax; others are in long flat pieces, two or three inches in length, an inch and a half wide, and a quarter of an inch thick; they are curiously marked all over with very slight indentations, giving the surface a stippled appearance. Generally however East Indian Copal is in irregular masses, having considerable transparency and a bright amber colour.

Australian Copal, Kawrie Gum, Australian Dammar, is the produce of Dammara australis (Nat. Ord. Coniferce). (Plate XIX. fig. 99.)-Large quantities of this gum-resin are now imported from Australia. It is probably in larger masses than any other gum-resin; a specimen in the Liverpool Collection of Imports measures nearly two feet round at its largest circumference, it is as large as a child's liead; the colour is a dull amber.

All the species of Copal strongly resemble amber; like it they also frequently contain insects and other extraneous matters; and it is highly probable they are the origin of 
that much-valued fossil resin. They are extensively used in the manufacture of varnish, for which purpose they are dissolved in alcohol or turpentine. Nearly 300 tons were imported in 1852, chiefly from Africa and Australia.

Gum Mastic.-The produce of Pistacia Lentiscus. (Nat. Ord. Anacardiacece.)

This plant and its resin were known to the ancients under the name of Schinos ( $\sigma \chi \hat{\imath} \nu \circ s$ ), and was supposed to have many medicinal virtues. Gum Mastic is in small round or ovoid tears, rarely larger than a pea, and often slightly flattened; they have a light yellow colour, and are only slightly transparent. Mastic has a sweet, resinous smell, and on that account is much used by the Turkish ladies, who chew it to sweeten the breath and preserve the gums. The bush which produces it is a native of Chio, the south of Europe, and Northern Africa; it is procured by cutting the bark transversely, upon which the mastic exudes in tears, and either hardens upon the tree, or. falls to the ground; that which falls constitutes an inferior quality. It is principally used in making varnish, for varnishing pictures, etc., upon paper and canvas; dentists also employ it in filling hollow teeth. About ten or twelve tons are annually imported, chiefly from the Levant. 



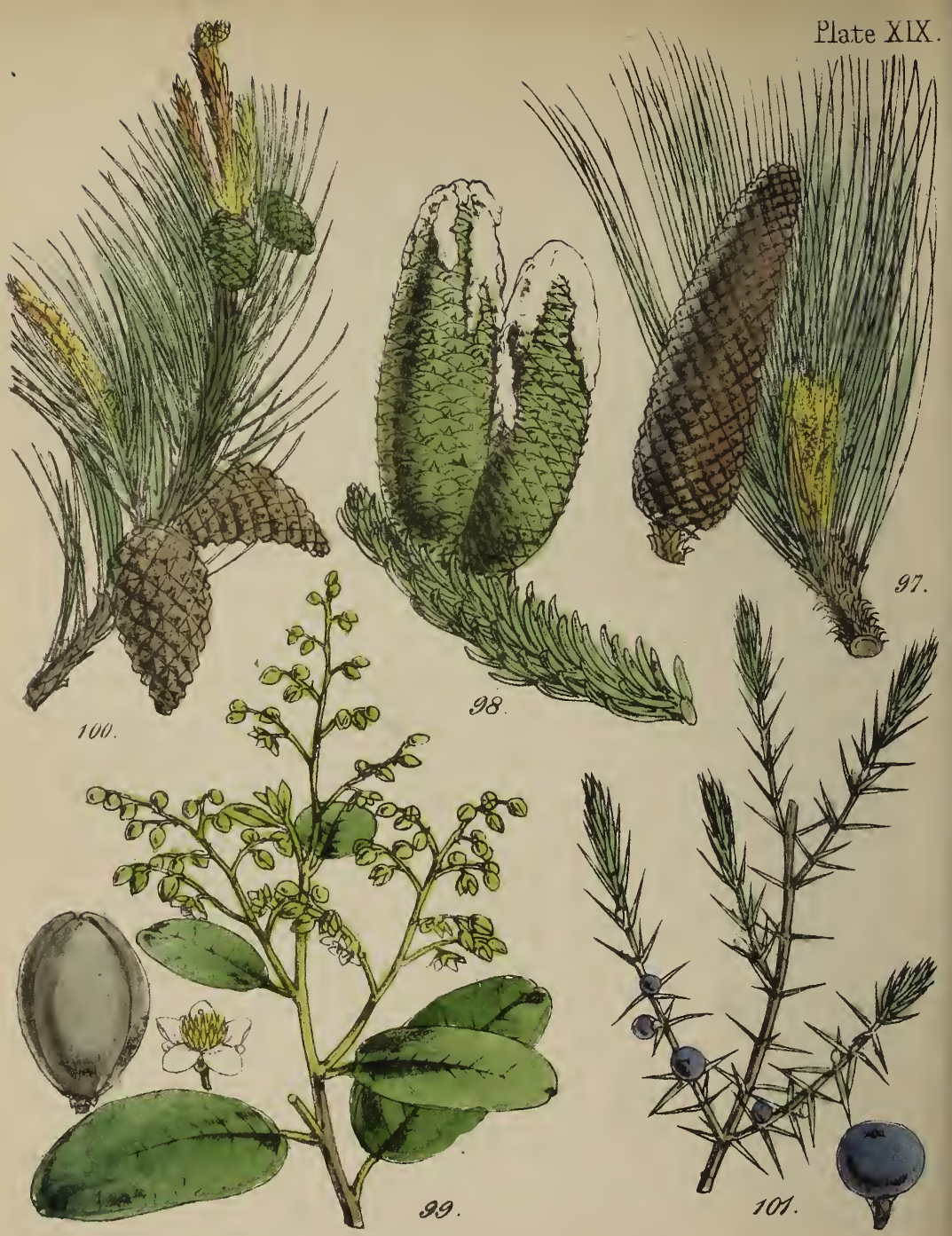

97. Turpertine Tree. 98. Canada Balsam. 99. Gum dammax 100 Tar \& Pitch Tree. 101. Juniper. 
Gum Juniper, or Gum Sandarach.-This Gum is produced by Callitris quadrivalvis, called the Arar-tree in Barbary (Nat. Ord. Coniferce).

It is from the wood of this tree that the Turks form the ceilings and floors of their mosques, it being considered by them almost indestructible. The gum is in long thin tears, rarely exceeding half an inch in length, and one-sixteenth of an inch in thickness; it is not unlike mastic, but is whiter, and has a more resinous and less agreeable odour. It is used for making fine varnishes, and formerly was much used in manufacturing pounce for writing, which was merely powdered sandarach; the invention of blotting-paper has however rendered it useless for this purpose. The imports are about twelve to fifteen tons anmually.

TURPENTINE. - An oleo-resin (combination of resin and oil) which flows from incisions made in the stems of various trees belonging to the Coniferous order. The principal are Pinus palustris (Plate XIX. fig. 97) and Pinus Tada.

These trees furnish the North American turpentine, which is now almost the only kind imported. They are found in the forests of North Carolina and Virginia, where amazing quantities of turpentine are collected and exported to all parts of the world. It reaches us in barrels holding from 
two to two and a half hundredweights, and has the consistency and appearance of honey, sometimes white and sometimes yellow in colour, generally much mixed with inpurities, such as fragments of bark, small twigs, etc. When distilled the turpentine of commerce yields from 14 to 16 per cent. of a fine colourless essential oil, usually called Spirits of Turpentine; the residue is the Rosin or Resin of the shops. The economic purposes to which these two products are applied are very various : the former is essential to the manufacture of paint, and the latter is much employed in the manufacture of common soap, in caulking ships, making the common kinds of sealing-wax, and many other uses. Rosin is of two kinds, yellow and brown or Zlack; the latter has been called Colophony: the difference depends upon the duration of the process of distillation, the resin getting darker the longer the heat is continued. The quantity of turpentine imported in 1851 was 21,731 tons, besides 12,000 gallons of the distilled oil, and 1900 tons of rosin.

There are two or three other products, which are either oleo-resins or products of them.-

Thus, or Frankincense, wuch used in pharmacy for making plaisters, - a turpentine from which most of the 
essential oil has evaporated naturally. Thus, properly speaking, is the turpentine of Abies resince (Conifera), but the hardened American turpentine above mentioned is more generally substituted for it. Mixed with perfumed gums, it is burned as incense in the performance of Roman Catholic ceremonials.

CANADA BaLSAM, a clear, transparent oleo-resin, which exudes from Abies balsamea (Coniferc) (Plate XIX. fig. 98); it is about the thickness of sperm oil, but soon gets less fluid; it is used chiefly for preparing microscopic objects, by rendering them transparent, and in making some varnishes.

TAR is a product procured by a species of distillation termed distillation per descensum, from the roots of various Coniferous trees, particularly Pinus sylvestris (Plate XIX. fig. 100). It was known to the ancients, and the mode of preparation described by Theophrastus was nearly the same as that now employed. A bank is chosen in the forests near which the timber is plentiful. In this bank a circular hole is made, the sides of which are beaten very hard; at the bottom a cast-iron pan, having a spout, is placed; a tube is fitted to the spout, and passes through the side of the bank. The large hole is then filled with billets, nicely cu 
and packed, of the wood of the roots of the pine; the mass is then ignited and covered over with soil. Combustion is thus carried on very slowly, and the tar which distils runs down the sides into the iron pan, and is given off through the spout, from which it is received into barrels. Nearly all the tar we receive from abroad is from Russia and Norway. In 1851 it amounted to 12,096 lasts measure, or about 24,000 tons weight. Tar is about the colour and consistency of treacle, and is used chiefly for the purpose of preserving cordage and wood from the effects of the atmosphere.

Piтch is procured by distillation from tar, in the same manner as rosin from turpentine. It is a black, solid, and glossy substance, with a brittle, shining fracture ; it is used for similar purposes to tar, with which it is often mixed, and also for caulking the seams of vessels; it was well known to the ancients. The pitch used in this country is mostly home-manufactured. Natural evaporation of the volatile portions of tar will of course convert that product into pitch.

Asphalte is fossil pitch.

The two next substances, though they are not, strictly speaking, gums or resins, are nevertheless inspissated juices 
procured from trees, in the same way as the turpentines. They have many peculiar properties, rendering them totally distinct from the products already described in this chapter. The first is-

India-Rubber, Gum Elastic, or Caoutchouc.-This now well-known substance is derived from various plants, but that which reaches England is almost entirely the produce of Siphonia elastica (Nat. Ord. Euphorbiacece). (Plate XVIII. fig. 94.)

The Siphonia (Hevea of Aublet) is a fine tree, attaining a height of sixty to seventy feet, with a stem clear of branches for forty or fifty feet of its height, as round as if turned, with a diameter of about three feet at the base, and lessening very gradually; the bark is of a light stone-colour. In order to procure the caoutchouc, the natives who collect it pierce the stem of the tree with a small pickaxe early in the morning; around this incision they mould soft clay in the form of a bowl, into which the juice runs pretty freely to the extent of about four ounces daily. They collect this juice each evening, and smear it over clay moulds of bottles, balls, shoes, etc. After each process the moulds thus coated are suspended in the smoke of a chimney, where they dry and get a black colour. Successive layers are added until 
they are of sufficient thickness; the clay is then washed out, and the caoutchouc is ready for market.

Formerly much was sent from British India; it was the produce of Ficus elastica (Nat. Ord. Moracece); but this is found to be so inferior to that produced by the Brazilian India-rubber tree, that it is almost unsaleable in our markets.

This remarkable vegetable production was first introduced in the eighteenth century. When it was introduced as a curiosity from America, it was in the form of bottles, birds, etc., and excited considerable attention in consequence of its elasticity and inflammability. At first it was used almost solely for rubbing out black-lead pencil marks from paper, hence its familiar name. Nothing was known of the plant from which it was produced, or the mode of production, until an astronomical expedition of French academicians went to South America. M. de la Condamine was fortunate enough to see the caoutchouc prepared, and forwarded an account of it to the French Academy in 1763 .

When pure, caoutchouc is very different to the article in common use; instead of black it has a pale yellow colour. It arrives in various forms; the commonest is Bottle Incliarubber: this variety is in various forms, as bottles, shoes, 
GUTTA-PERCHA.

models of animals, balls, etc. Sheet India-rubber is in flat pieces about a foot broad, two feet long, and about half an inch in thickness; these pieces are folded lengthwise like sheets of paper: it fetches a high price, and is esteemed the most valuable. And Pipe India-rubber, in tubes a foot long, and one inch and a half in diameter.

The property possessed by caoutchouc of dissolving in coal naphtha, renders it extremely valuable in the arts, and its applications have become extremely numerous. The quantity annually imported is less than would be supposed from the extent to which it is used; only between 500 and 600 tons were imported in 1852.

Gutta-Percha (Plate XVIII. fig. 96) in some of its characters strongly resembles caoutchouc; it is the produce of Isonandra Gutta, Hooker, (Plate XVIII. fig. 95.)

The Gutta-percha tree is found growing in Singapore, Borneo, and other Malay Islands, where it is one of the largest timber-trees; its light spongy wood is however of little value. The leaves are alternate on the branches, somewhat leathery in texture, entire in their outline, and obovate in form; they are green above, and a shining orange colour beneath, and are attached by long petioles. The flowers are produced in little tutts from the axils of the 
leaves ; they are small, each on a distinct peduncle. They are tubular or monopetalous flowers, with the tube short, and spreading into six elliptical segments. The stamens are twelve in number, as long as the segments of the corolla; the pistil is simple, and longer than the stamens.

At present the mode of procuring the milky juice which constitutes the gutta-percha is so destructive, that unless the Malays can be taught to use greater care, the guttapercha trees of the Malayan Archipelago will soon be exterminated. The finest trees are selected and felled, the bark stripped off, and the milky juice which is found between the bark and wood is collected in small troughs made from the stalk of the plantain-leaf; as the juice coagulates it is kneaded into cakes for exportation. Each tree produces from twenty to thirty pounds of gutta-percha. When hardened by exposure to the air, this gum (Plate XVIII. fig. 96) has a light brown colour resembling leather, a remarkable odour of cheese, and a spongy or cork-like texture; it is mixed with many impurities, which have to be separated by softening it in hot water and re-kneading it; this process is termed "devilling" by the operators.

It is imported in blocks of various shapes, but usually in square cakes about eighteen inches in length, nine in breadth, 
and three inches in thickness. When refined it is more compact, has a darker colour, and, when rolled, a glossy surface ; it is not possessed of the elasticity of caoutchouc, but is flexible, and has the remarkable property of being ductile and plastic when softened by warmth; the consequence is, it can be made to take any form, which it retains with extraordinary sharpness of outline when cold. Its applications are almost innumerable; perhaps the most useful has been the coating of the wires of the submarine telegraph, for which, from its perfect non-conducting property, it is most admirably adapted. Dr. Montgomerie was the first to bring Gutta-percha into notice, and the following extract from his account in the 'Magazine of Sciences,' for 1845 , has much interest. "I may not claim the actual discovery of gutta-percha, for, though quite unknown to Europeans, a few inhabitants of certain parts of the Malay forests were acquainted with it. Many of their neighbours residing in the adjacent native villages had never heard of it. It was occasionally employed to make handles for parangs, instead of wood or buffalo-horn. So long ago as 1822, when assistant-surgeon at Singapore, I was told of guttapercha in connection with caoutchouc. There are three varieties of this substance-Gutta Girek, Gutta Tuban, and 
Gulta Percha (the $c h$ in the latter being pronounced as in perch, a fish). The name is pure Malayan; Gutta meaning the gum or concrete juice of the plant, and Percha the particular tree from which it is obtained. I could not help thinking that the tree itself must exist in Sumatra, and perhaps derive its name from thence, the Malayan name for Sumatra being Pulo Percha; but though the Straits of Malacca are situated only one degree to the north of Singapore, I could not find that the substance has ever been heard of there or in Sumatra."

The imports of this article have increased very rapidly; they amounted last year (1852) to nearly 1000 tons.

Many other gums and resins are imported, but of those undescribed in this chapter the greater part are used in pharmacy, and consequently belong to the chapter on Materia Medica, where a description of some of the most interesting will be found. 


\section{CHAPTER XI.}

OILS, OIL-SEEDS, ETC.

The oleaginous products of plants may be divided into three distinct divisions :- those which are solid at the ordinary temperature of our climate; those which are liquid; and those which are liquid and volatile. It is almost impossible to estimate the value of this class of products, their uses are so numerous and extensive. The African, under the burning tropics, collects a vegetable butter which is of vast importance to railway locomotion; and the same article enters into the manufacture of soap, the consequent cheapness of which has doubtless exercised immense influence upon the sanatory condition of our poorer classes. India sends us another vegetable fat, which also enters into the composition of cheap soap, but is more used for making 
stearine candles and marine soap. Southern Europe sends a sweet vegetable oil, the use of which renders our woollen cloths more durable and beautiful; and the essential oils, which are collected in many parts of the world, enable us to communicate the odour and flavour of the most admired plants to food, confectionery, medicine, and perfumery. All oils naturally formed consist of two other oils, one solid, stearine; the other fluid, oleine or elaine. In some vegetable oils the mixture of the two is owing to the temperature, any decrease of which precipitates the solid from the fluid; as, for instance, when olive oil is acted upon by cold. Oleine and stearine are oxides of a peculiar substance called by chemists glyceryle, from its liquorice-like sweetness ; in other words, oleine consists of an acid called oleic acid, and this sweet substance glyceryle, whilst stearine is a compound of stearic acid and glyceryle. This peculiar composition of oils, both animal and vegetable, leads to their great value in the formation of soaps, the process of which consists in combining either soda or potash with the stearic and oleic acids; this is easily effected, as the acids have a greater affinity for the alkalies than for the glyceryle. The solid vegetable fats are- 
PaLm OrL.-Principally produced from the fruit of the Palm Elais Guineensis. (Nat. Ord. Palmacea.) (Plate VIII. fig. 42.) It is also produced by another species of Elais, E. melanococca.

The fruit of the Elais Guineensis forms an immense head, resembling a monstrous pine-apple; it consists of a great number of drupes of a bright orange-yellow colour; these drupes have a thin external skin (epicarp), through which the yellow oily pulp (sarcocarp) is seen ; in this is the hard stone (endocarp), which occupies about one-fourth of the whole bulk of the drupe, the sarcocarp constituting nearly all the remaining portion, of which two-thirds are oil or palm butter.

Palm oil is of a beautiful deep orange-yellow colour, becoming lighter by exposure to the air and light; it has a sweet violet odour when fresh. Besides oleine, it consists of a distinct principle called palmitine, taking the place of ordinary stearine, of which probably it is only a variety.

When we reflect that palm oil is used in Africa as butter by the natives, over an immense and thickly populated portion of that continent, the quantity imported into this country is really astounding, and gives us an idea of the prolific nature of these palms, greater than we could other- 
wise have conceived. Let us take a glance at its uses : first, in its native country it furnishes, under the name of ghea (butter), a portion of the food of the natives, probably not less than a million and a half in number; then in our own and other countries it forms a moiety of the antifrictional compound which gives safety to the wheels of every railway-carriage : these (according to Mr. Braithwaite Poole, probably the best authority in the kingdom) are in our country no less than 108,284 in number, representing a capital of $£ 15,657,890$; we may then double this for the whole of the European railways, and without exaggeration may affirm that palm oil assists the motion of railway carriages so numerous as to be worth in round numbers $£ 32,000,000$; besides which it forms a large proportion of one-third at least of the common hard soap manufactured in this country, or in figures, one of the principal constituents of 17,800 tons of hard soap. These results show to what an extent European enterprise has stimulated the industry of the negroes of Africa, furnishing them with a trade more lucrative than the demoniacal traffic which previously constituted their chief occupation. The numbers employed in collecting the fruit, in pressing the berries, and in conveying the oil to the coast merchants, must be im- 
mense, and the time cannot be far distant, if nature continues her beneficence, when labour will be so much wanted on the coast of Africa that the sale of human beings will be no longer possible. The imports of palm oil to England alone are nearly 50,000 tuns per annum.

The Oil Palm, besides this palm butter, yields a limpid oil from the hard stony endocarp; very little of the oil has been imported, but under the name of palm-nuts, these seeds have been brought to this country, for expression of the oil, in considerable quantities.

Cocon-NUT or CoKer-NuT OIL-is another solid vegetable fat, produced by the Cocoa-nut Palm (Cocos nucifera). (Plate IX. fig. 44.)

This fat is expressed from the white albumen of the cocoanut kernel ; it is as white as lard and rather harder, having a peculiar odour, which is not very agreeable, or rather it becomes very disagreeable if often smelled, even to those who at first did not dislike it, otherwise it would be much more extensively used both in soaps and pomatums; in the former it is sometimes used for the very coarse kinds, and also for marine soap; it is chiefly used for making cocoa stearine (or cocinine), of which excellent candles are manu- 
factured. The imports in 1851 were 4902 tons, almost the whole of which came from Manilla and Ceylon.

The fluid oils used in manufacturing processes are-

OuIve OiL-expressed, or otherwise obtained, from the fruit of the common Olive (Olea Europcea, Nat. Ord. Oleacea). (Plate IV. fig. 16.)

The olive had already been described in the chapter on fruits, therefore the oil now only remains to be described. It is a fine thin fluid, varying in colour from a light green to a pale straw-colour; when exposed to a temperature but little below the average in this country, its stearine separates and falls down in white flocculent masses; and the whole of it congeals at the freezing-point of water. It is generally obtained by expression in a rude mill, consisting of a large conical mass of stone with an axis of wood, to which a horse is attached. The pressing stone revolves upon a circular stone platform, around which is cut a small groove ; as the olives are crushed, the oil runs into the groove, from which it is conducted into vessels placed to receive it. It varies very much in quality, from the fine Lucca Oil used in salads, to the almost rancid Spanish kinds, which are used for viling machinery. The chief use of olive oil is in dressing woollen cloths. We receive it in great quantities 
from Galipoli, in the Neapolitan dominions, Sicily, Spain, Portugal, for manufacturing and machinery purposes; and the finer table-kinds from Florence, Leghorn, Lucca, Genoa, and the South of France. In 1851, 20,783 tuns, of 252 gallons each, were imported.

Almond OIL is obtained by expression from the sweet and bitter Almond (Amygdalus communis, varieties $\boldsymbol{a}$ and $\beta$ ). It is a beautiful clear straw-coloured oil, inclining to yellow; its chief use is in perfumery and for lubricating the machinery of clocks, watches, and other small pieces of mechanism. It is very rarely imported, being principally expressed in this country.

RAPE OIL is expressed from the seeds of the Rape (Brassica Napus, Nat. Ord. Crucifera).-This oil is rather browner and darker than olive oil, but when refined is nearly as limpid; it is much used for burning in lamps, especially in France. We imported 107,029 quarters of ape-seed, and about 300 tuns of the oil, in 1851, chiefly from France and Germany.

Sted OrL.-Under this name a large quantity, amounting now to nearly 1000 tuns per annum, of a fine odourless oil, resembling rape-oil, of a sherry-brown colour, is imported into Liverpool from Lisbon. It is expressed 
from the nuts or seeds of Jatropha Curcas (Nat. Ord. Euphorbiacea), a plant closely allied to the Croton, so celebrated for its medicinal oil : it was first used in Lisbon by the contractor for lighting the public streets, who made it from a quantity of the seeds brought from the Cape de Verd Islands. So useful was it found as an oil for burning, that eventually it took the place of every other, and the streets of that capital are now wholly lighted with seed oil, a name given for the purpose of hiding its real origin. The widow of the above-mentioned contractor now carries on a large trade in this oil, and it has been found to answer in this country for cloth-dressing, which, in consequence of the irregular supply of olive oil, makes it a very valuable acquisition. The only objection to its employment in the factories is its highly drastic property, which renders its use somewhat inconvenient amongst ignorant and careless workpeople, who are apt to taste the oils they use while working.

The Jatropha seeds are about half an inch in length, of a slightly flattened oval figure, of a dull brown, sometimes almost black colour. Their first import into Liverpool, under the name of Croton nuts, led to much mischief; the persons employed in the unlading, misled by the term nut, 
finding them sweet to the taste, ate them, until they produced a distressing illness; numbers of poor children also suffered from finding them upon the quays, and many were taken to the hospitals in consequence. The nuts are only imported occasionally.

LINSEED. - The seed of Linum usitatissimum (Nat. Ord. Linacea.)-This plant was described under the name of Flax. Linseed oil is not often imported, but the seed, which is small, flat, oval, and of a shining bright brown colour, is imported in very large quantities; in 1851 the imports were 608,986 quarters, the greater part of which was from the East Indies and Russia; smaller quantities were received from Prussia, Germany, Egypt, and America.

Teel Seed, Til Seed, Gingely or Grngildie Seed, Sesamum Seed, and Bennie Seed.-Under these various names we receive the seed of Sesamum orientale (Nat. Ord. Pedaliacea). Its oil, owing to the readiness with which it becomes rancid, is seldom or never imported, but large quantities of the seed are brought from the East Indies, Egypt, Africa, and occasionally from Brazil. The plant thrives everywhere in the tropics, and is largely cultivated all through India, where its oil is much esteemed; it is clear, limpid, and when fresh, as sweet as almond oil. The 
seeds are about the size of linseed, but though flattened and oval, they are not thin at the edges like that seed; their colour is of various shades from ash-grey to deep brown; the oil contained in them is in very large proportion.

Niger Seed is the produce of Guizotia oleifera; the Verbesina sativa of Lessing, (Nat. Ord. Composita.) This is another oil-seed from India, where it is very extensively cultivated. In that country the oil is variously named in different localities, as Ram-til, Kala-til, Noog, Valisaloo noonæ, etc. ; it is very thin, contains but little stearine, and is useful in painting, and various other purposes requiring a very thin oil. 700 or 800 quarters is about the greatest amount of the seed received here in one year. The oil has not been imported.

Carthamus Seed. - The seeds of the Safflower plant, Carthamus tinctorius (Nat. Ord. Compositc). These seeds are about the size of small sunflower seeds, exactly the same shape, and of a cream-white colour. In India, from whence they come, the oil is expressed in large quantities, under the name of Koosum Oil. Considerable imports of the seed have been received, and the oil is said to be in great demand for making fancy soaps, but the Koosum oil has never been imported. 
Mustard Seed.-The seed of a species of Mustard, Sinapis glauca (Nat. Ord. Cruciferc), is very "largely imported from the East Indies for the expression of oil; it is a small, round, brown seed, very closely resembling rape-seed; it is probably mixed with other species, as $S$. Toria and $S$. nigra, natives of the East Indies.

Cotton Seed. - The seeds of Gossypium herbaceum (Nat. Ord. Malvacea) are often imported for expressing; the oil they yield is used as a substitute for olive oil. Cotton-seeds are about the size of small peas, of a deep brown colour; they are usually loose, but sometimes come just as they are taken from the capsules, that is, they are held in kidney-shaped clusters, four of which, with the cotton, occupy each capsule; each cluster contains about ten seeds. The imports have hitherto been small, and always from the United States of America.

Poppy Seed (Papaver somiiferum, Nat. Ord. Papaveracea) is often imported from India and the European Continent; the oil expressed from it is so bland and sweet, as to equal the finest produce of the olive. In France, where it was first introduced, poppy-seed oil was subjected to a prohibitory decree, owing to the mistaken idea, that, being derived from the same poppy-heads that yield opium, 
it must necessarily be poisonous. Since this fallacy has been exposed, and the prohibition removed, poppy-oil has been much used in France as a substitute for olive oil, both in the manufactures and for table use; and latterly several imports of the oil have been received in this country.

Ground Nut. Arachis hypogea. (Nat. Ord. Leguminosa.) (Plate VI. fig. 31.) Large consignments of this seed are from time to time received from the African coast for the expression of oil. The produce is a fine thin strawcoloured oil, resembling poppy oil and the finer varieties of oil of olives. The oil itself has been imported occasionally, but in small quantities. It is very free from stearine, and is consequently used extensively by watch-makers and others for delicate machinery. In India its use in cooking and for the table is very extensive; it is there called Katchung Oil.

Several other seeds are used for the expression of their oil; thus, the common Hazel-nut, Corylus Avellana, which yields a fine limpid oil, so free from stearine, that it is preferred before all others for watch machinery. Its value in this respect can hardly be too highly rated, for independent of its perfect liquidity, it is slow in drying, consequently requiring only an occasional renewal. To this quality 
probably one-half of the value of our watches is owing, for without such a means of diminishing the friction, the delicate machinery would soon be disordered by injurious wearing of the pinions, axles of the wheels, and other rapidly moving parts.

Ben Nuts, called in France Pois quéniques and Chicot, are also imported from the East Indies, and yield an oil which is highly prized by painters in consequence of its fine limpid and rapid-drying qualities. It is the seed of Moringia pterygosperma, a small tree of rather anomalous character. In consequence of its leguminous-looking capsules and doubly pinnated foliage, it was referred by De Candolie and others to the Natural Order Leguminosa; but it has been demonstrated by Mr. Robert Brown and others, that it is totally distinct from that Order : that eminent botanist constituted the Order Moringea for this small group of plants; but as the terminology of Dr. Lindley has been generally adopted in this work, Moringacea will be the most proper name for the Natural Order. The Ben-nuts are somewhat larger than horse-beans; they are nearly round, inclining to oval, with a slight flattening on two sides. Their colour is a light ash-grey, with a polished shining porcelain appearance. They are of rare occurrence in our markets. 
The Essential Oils differ materially from the fixed oils already described, both in their characters, and also in the methods by which they are obtained. As a group, they are again divisible into three distinct classes, distinguishable by their chemical characters. Thus, the first class are simple compounds of carbon and hydrogen $(\mathrm{C} \mathrm{H})$; by chemists they are termed non-oxygenated oils. They are very inflammable, burning like coal-gas, of which they appear to be a mere concentration. Although they contain no oxygen when pure, if exposed to the atmosphere they gradually absorb it, and are converted into resins. They are very volatile, and rapidly decrease by evaporation at the ordinary temperature; if the temperature be raised, they evaporate entirely. They are nearly all obtained by distillation.

The Oil or Spirit of Turpentine, distilled from common turpentine, is the type of this class. They are all odoriferous, usually having the odour of the material from which they are procured. Besides turpentine, the other non-oxygenated oils met with in commerce are-

Oil or Essence of Lemons. - This oil exists so abundantly in the cysts which are found in great numbers in the flavedo, or yellow portion of the rind of the fruit of 
the lemon, that it can be obtained either by expression or distillation. The former process is generally adopted. It is imported in large copper vessels called cylinders, varying in size, but rarely exceeding six gallons. It is received chiefly from Messina and Palermo, but considerable quantities are also imported at times from Portugal. About $10,000 \mathrm{lbs}$. are annually brought to this country. It is used in confectionery and perfumery.

Oil or Essence of Bergamot.-This oil is obtained in the same manner as the last, from the rind of the Bergamot Orange, Citrus Bergamia (Aurantiacea). About 8000 lbs. are annually brought from Sicily, the whole of which is consumed in perfumery.

Oil of Orange is obtained by distillation with water from the rind of the Sweet Orange. Used in perfumery.

Orl of Orange Leaf, or Essence de Petit Grain, is procured by distillation from the green leaves of the Orange-tree. Also used by perfumers.

Oil of Neroli, Essence of Neroli, or Oil of Orange Flowers, distilled from the flowers of various species of the orange tribe, but chiefly from those of the Common Orange. This oil constitutes a very delicate perfume; the odour of the favourite Eau de Cologne is owing 
to its presence, that perfume, when properly prepared, being a distillation of orange-flowers with alcohol. Spurious Eau de Cologne is made by dissolving the Oil of Neroli in weak spirit-of-wine.

There is a deliciously scented oil called Cetronelute, imported from Ceylon in small quantities; it is generally said to be from Citron-flowers. The author is very doubtful of this origin, and believes rather that it is the produce of one of the species of Andropogon, to which genus the Lemon-grass of India also belongs. It usually arrives in cases with the lemon-grass oil, a case often consisting of twelve small bottles, or six of each of these essential oils; besides which it apparently belongs to the oxygenated essential oils, whereas all the other volatile oils procured from the Aurantiacece are non-oxygenated. The Oil of Cetronelle is largely used for scenting the soap called Honey Soap, now much used.

OIL of Juniper, distilled from the berries and young shoots of the Common Juniper (Juniperus communis: Conifer $\propto$ ). (Plate XIX. fig. 101.) It is used in giving a spurious flavour to gin, and also in pharmacy. From Germany. The Second Class of Essential Oils contain oxygen in addition to carbon and hydrogen $(\mathrm{CH} \mathrm{O})$; they are con- 
ESSENTIAL OILS.

sequently termed oxygenated oils. The following oils of this class occur in commerce :-

OIL OF LAVENDER, distilled from the flowers of the Common Lavender, Lavandula spicata (Nat. Ord. Labiatc), is imported from France and Germany, but the foreign oil is much inferior to that made in this country. Very large quantities of this and several other essential oils have been manufactured for some time at Mitcham, in Surrey, and the English essential oils have gained pre-eminence over all others. It is exclusively used in perfumery.

Ort of Rosemary, distilled from the leaves of Rosemary (Rosmarinus officinalis, Nat. Ord. Labiatce).-This oil is very rarely imported, as it is procured in great abundance and at a very cheap rate in England.

Oil of Thyme, Oil of Origanum.-These two names would imply that the oil was distilled from two plants, the Thyme and Marjoram, but it is now generally understood that the common thyme, Thymus vulgaris (Nat. Ord. Labiatce), yields the oil which bears these names; it is distilled from all parts of the plant. Occasional imports are received from Hamburg, and latterly from the United States. It is used in scenting Windsor soap and in veterinary pharmacy. 
Oil of Peppermint is distilled from the leaves of the Peppermint, Mentha piperita (Labiata). It is much used in confectionery and pharmacy. Besides the home manufacture, which is most highly esteemed, we receive about 12,000 lbs. annually from Germany and the United States.

Oil of Mint is manufactured by distillation from the leaves of the Common Spearmint of the herb-garden, Mentha viridis. This, and the essential oil of another Labiate plant, Mentha Pulegium, the Pennyroyal, are chiefly used in pharmacy, and consequently hardly belong to this chapter. They are rarely imported.

Oil of Cloves, distilled from the dried flower-buds (Cloves) of the Clove-tree.

Orl of Nutuegs, distilled from the various kinds of nutmeg.

Orl of Pimento, distilled from the Jamaica Allspice.

Oils of Cinnamon and Cassia, distilled from the Cinnamon and Cassia barks ; the former is imported from Ceylon, and the latter from China, in considerable quantities.

These essential oils of the spices are used both in confectionery and pharmacy.

Oil of AnIseEp, distilled from the seeds (fruit) of Pimpinella Anisum (Nat..Ord. Umbellifera). It has the 
ESSENTIAL OILS.

singular property of congealing at the temperature of $54^{\circ}$ Fahrenheit. It is largely imported from the East Indies and from Germany; as much as $4500 \mathrm{lbs}$. have been imported in one year. It is used in flavouring spirits and cordials, and also in pharmacy.

Oil of Caraway is distilled from the seeds (fruit) of Carum Carui (Umbelliferce). Small quantities are occasionally imported from Germany, much more is home manufactured and exported. Its uses are similar to those of the preceding one.

Oil of Roses, Attar of Roses, Otto of Roses.This most valued essential oil is distilled from the petals of one or more species of Rose (the exact species are not known to Europeans) ; its costliness can be easily understood when it is known that the produce of 10,000 rose-bushes, taken at 100,000 roses, is required to yield 180 grains, or three drachms, of pure Attar. Being the favourite perfume of the whole civilized world, we are lost in amazement when we attempt to reflect upon the quantity of rose-leaves required in this manufacture. England alone receives about $1000 \mathrm{lbs}$. annually, and France probably half as much more. In eastern countries it is a most essential luxury; "the Attar Gul's Perfume" is found at the toilet of every 
Asiatic beauty. In Cashmere, the harvest of rose-leaves is celebrated as the festival of the year, and its description in Moore's exquisite poetry is now universally known:-

"Who has not heard of the Vale of Cashmere,

With its roses, the brightest that earth ever gave?"

"But never yet, by night or day,

In dew of Spring or Summer's ray,

Did the sweet valley shine so gay

As now it shines-all love and light!

Visions by day and feasts by night!

A happier smile illumes each brow,

With quicker spread each heart uncloses,

And all is ecstasy,-for now

The Valley holds its Feast of Roses."

We receive the attar from Smyrna and Constantinople either in very small flat square phials, holding only a few drops of the precious oil, or else in larger bottles, containing from two to eight ounces. In either case the bottles are of white flint-glass, ornamented with gilding, and the larger ones usually contain the better quality of oil. Like Oil of Aniseed, it has the property of congealing at the ordinary temperature of this country; at $80^{\circ}$ Fahr. attar of roses is a crystalline solid mass; its colour is usually a light yellow or straw-colour. Its high price leads to much adulteration. 
Oil of Tndian Grass, Roosa Oil, or Roosa-ke-til -is distilled from the leaves of Andropogon Calamusaromaticus, supposed by Dr. Royle to be the sweet calamus mentioned in Exodus xxx. 23, and the sweet cane, in Jere-

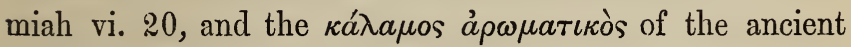
Greeks. It has a strong rose scent, too strong to be agreeable; in India its use is chiefly as a rubefacient in cases of rheumatism, but in this country it is most probably used for adulterating attar of roses. A genuine sample of this oil was contributed to the Liverpool Collection of Imports by the author, who received it from his friend Dr. Scholfield, of Birkenhead, a gentleman curious in Indian products, of which he has a choice collection.

OiL of Lemon-Grass-is distilled from another of the scented grasses, Andropogon citratum ?* Dr. Pereira confounds this with the Oil of Cetronelle, which however he rightly attributes to an andropopogon; but the author has had many and ample opportunities of seeing both these,oils, often imported in the same case; the one called lemon-grass (Andropogon Schcenanthus most probably) has the odour of

* In the Liverpool Botanic Gardens there is a tropical Andropogon, with a powerful verbena scent, which the curator, Mr. Shepherd, pointed out to the author as Andropogon Schcenanthus. It is most probably the Molucca Lemon-grass. 
the scented Verbena (Aloysia citriodora), and is used to imitate the perfume of that favourite plant ; both it and the Cetronelle Oil (? Andropogon citratum) are made at Baddegama, near Galle, inCeylon ; the former is always labelled Essential Oil of Molucca Lemon-Grass, and the latter Oil of Cetronelle. The lemon-grass oil by exposure absorbs oxygen much more readily than that of Cetronelle, and consequently soon becomes resinous. A specimen which has been in the author's collection about twelve months, contains small floating spiculæ of stearoptene. There are two or three other essential oils from the grasses of this genus; and probably the precious oil of spikenard mentioned in the Scriptures was derived from one of them, most likely from $A$. Iwarancusa.

Many other oils occasionally find their way to this country, but they do not constitute regular articles of commerce, or they are exclusively medicinal, and will be mentioned in the chapter on Materia Medica. We now proceed to the Vegetable Tallows and Waxes of various kinds.

Vegetable Tallow (Indian, from Singapore), obtained from the fruit of some plants of the Natural Order Dipteracea. This peculiar vegetable fat has been frequently imported lately in small quantities experimentally; it is totally distinct from the Piney Tallow of the East Indies, which is 



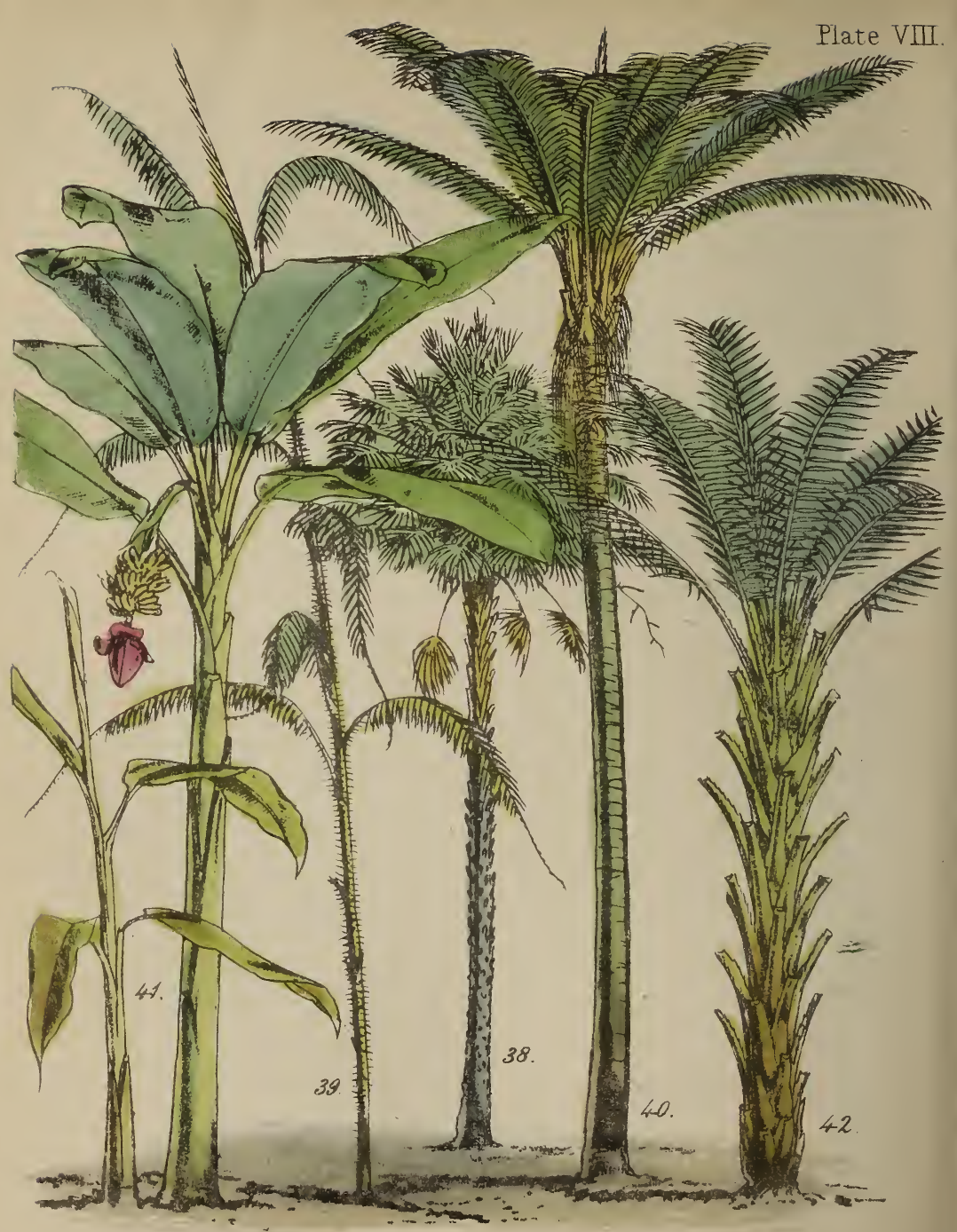

38 Carnauha Palm. 39. Rattan Palm. 40 Coquilla Nut Pahu 41. Manilla Plantian. 4i. Tha Oil Pata. 
also produced by a Dipterocarpous plant (Vateria Indica); both are imported from India, but the former, instead of being white, is of a yellowish-green colour, evidently from the admixture of some balsamic resin, which also gives an agreeable balsamic odour to this substance. Its chief value is for the manufacture of candles, which give out a sweet smell in burning. It resembles ordinary tallow in its consistency, but small particles appear through its substance, having a resinous lustre.

Vegetable Tallow (Chinese, from Canton) is procured from the seeds of Croton sebiferum (Nat. Ord. Euphorbiacea). This kind is very different from the last, being of a cream-white colour, a tallowy odour, hard and brittle, and usually flaky, or in plates about an inch thick, or in lumps bearing the form of some vessel into which it has been melted; the flakes are apparently caused by different meltings being poured into the same pan. It becomes brown by exposure, and evidently contains some acid in abundance, probably crotonic; only a few small lots have been imported experimentally.

Vegetable Wax (South American).-A singular product from the leaves of Corypha cerifera, the Carnauba Palm. (Nat. Ord. Palmacea.) (Plate VIII. fig. 38.) 
The Carnauba is one of the finest palms of the Brazilian forests. Its fan-like leaves are placed in a tuft at the top of a hard solid stem growing from thirty to forty feet in height, the stalks of the leaves themselves being six or eight feet in length. When the leaves have attained perfection, they are found to be beautifully varnished with a thin coating of vegetable wax; they are then gathered, and laid in a cool dry place on cloths, where they naturally wither and shrink. In consequence of shrinking, the coat of wax cracks and peels off in small flakes; these are from time to time shaken off and collected. When sufficient of the wax is thus obtained, it is melted into small earthen pans, and when cooled turned out. The lumps imported bear the shape of the utensil in which they have been melted; they are about three or four pounds' weight each, of a light sulphuryellow colour, with a lustre between that of wax and resin, and rather brittle; five or six hundredweight are annually imported, chiefly from the province of Ceara in Brazil. Its use is said to be for mixing with common bees'wax, to give it greater firmness in various of its applications.

Vegetable Wax, or Myrtle Wax (of North America).Obtained by boiling and pressing the berries of the waxbearing Candle-berry Myrtle. (Myrica cerifera, Nat. Ord. 
Myricacea.) The wax exudes from the berries and forms a scum on the water in which they are boiled; this is collected and re-melted; it has a greenish-yellow colour and aromatic smell. In the United States this wax is used in country places to make candles; it rarely comes to England, except in very small quantities, and chiefly as a matter of curiosity.

To the student in Economic Botany, the Oil and Wax series is especially interesting, from the extreme value of their organic combinations in the various arts of civilized life. What would machinery be without oils? Even if the various engines of human invention could be made to work without the lubricating help of vegetable or animal oils, the wear from friction would be so great and rapid that the use of machinery would be almost doubled in costliness, and consequently would, in most instances, be unavailable. Those mentioned in this chapter are the most common commercial substances of this series, but there is a vast number which would be valuable if made known to the commercial enterprise of our merchants. 


\section{CHAPTER XII.}

\section{MISCELLANEOUS ARTICLES.}

"Sooty retainer to the vine, Bacchus' black servant, negro fine; Sorcerer, that mak'st us dote upon Thy begrimed complexion."

INCLUDED in this chapter will be found a collection of vegetable substances either more or less connected with the arts and manufactures, but not capable of being correctly arranged under any of the preceding chapters. Foremost in the list stands that poisonous weed on which Charles Lamb wrote the above lines, when striving to release himself from its debasing thraldom.

Toвacco-consists of the dried leaves of several species of Nicotiana (Nat. Ord. Solanacea). 
TOBACCO.

We have shown, in the history of Hemp, that the practice of inhaling the smoke of plants for the excitement or stupor thereby caused, did not originate with tobacco; for although Humboldt has produced sufficient evidence to prove that the natives of Orinoko cultivated and used tobacco from time immemorial, there is equally strong historic proof that various herbs were used by the ancients of the Old World - for the same purpose. Though only known to Europeans in 1492, when Columbus and his companions first saw the natives of Cuba smoking cigars, it has rapidly spread over the whole world, and civilized men have adopted as a luxury what in all probability was originally used as a necessity in the lowest states of savage life. It is impossible to say what accident first led to the use of this weed, but it is not improbable that its leaves were first chewed by some starving savage in the desperation of hunger : its remarkable effects in allaying the cravings of the stomach would be instantly appreciated; other modes of using it would soon be developed by accidental causes, and it would not be wonderful if the untutored savage should highly value properties to him so useful and extraordinary.

Tobacco was introduced to this country by Sir Francis Drake in 1586, and was immediately adopted by some of 
the beaus of the court, who prided themselves in aping the hardy voyagers who had trod the wilds of Virginia. Sir Walter Raleigh and a few other great names gave still greater encouragement to its adoption, so that before the end of Queen Elizabeth's reign the habit was by no means uncommon.

Nevertheless its pernicious effects were clearly seen by those not prejudiced in its favour, and strong efforts were made in every country to resist the progress of the evil. A German writer is said to have collected the titles of one hundred different works condemning its use, which were published within half a century from the date of its introduction to Europe. In Russia it was prohibited, and the smoker was threatened with the knout for the first offence, and death for the second. Pope Urban VIII. fulminated a bull against the use of tobacco, but the anathema fell to the ground. The priests and Sultans of Turkey and Persia declared smoking a sin against their holy religion; but the Turks and Persians became the greatest smokers in the world. In our own country James I. wrote a treatise against it, entitled 'A Counterblaste to Tobacco,' which excited much attention, but, instead of checking the use of the weed, probably introduced it to the notice of many who 
had not before known of it. This evil, like many others, throve by persecution, until it became almost intolerable, even ladies indulging in its use; and the same untenable arguments were adduced in its defence which in the present day are in the mouth of every juvenile aspirant for the manly power of smoking; the pipe and cigar having assumed the place of the toga viritis. We have an amusing proof of the favour it found with the fair sex in a letter written in 1700, by the humorous writer Tom Brown.

\section{"To an Old Lady that smoked Tobacco.}

"MaDaM,-

"Though the ill-natured world censures you for smoking, yet I would advise you, Madam, not to part with so innocent a diversion. In the first place it is healthful, and, as Galen rightly observes, is a sovereign remedy for the toothache, the constant persecutor of old ladies. Secondly, tobacco, though it be a heathenish weed, it is a great help to Christian meditations; which is the reason, I suppose, that recommends it to your parsons, who could no more write a sermon without a pipe in their mouths than a concordance in their hands; besides every pipe you break may serve to put you in mind of mortality, and show you 
upon what slender accidents man's life depends. I knew a Dissenting minister who on fast-days used to mortify upon a rump of beef, because it put him, as he said, in mind that all flesh was grass; but I am sure that much more is to be learned from tobacco: it may instruct you that riches, beauty, and all the glories of the world, vanish like a vapour. Thirdly, it is a pretty plaything. Fourthly and lastly, it is fashionable, at least 'tis in a fair way of becoming so. Cold tea, you know, has been a long while in reputation at Court, and the gill as naturally ushers in the pipe, as the sword-bearer walks before the Lord Mayor."

In our own time the cigarette is by no means uncommon between the ruby lips of the fair dames of Portugal and Brazil, but thanks to that vice of selfishness which seems to be fostered by tobacco, it is not tolerated in other civilized countries as one of the pleasures of the fair sex, though confessedly an exquisite enjoyment to their male companions.

Medical men are much divided in opinion as to the effects of smoking tobacco as a regular habit; the evidence pro and con. would at first sight appear to be pretty nearly balanced, but of those who speak favourably of its effects 
many are smokers themselves, and a great allowance must be made for prejudice, thereby giving a preponderance of authority for disapproving the practice. Its power of resisting contagion, formerly held forth as one of its strongest apologies, is now disbelieved by all well-informed physiologists ; whilst its injurious effects upon the digestive and secretory powers of many constitutions requires no confirmation.

Tobacco is used in the form of dried leaves coarsely broken (German Knaster); the dried leaves cut into fine threads (Cut Tobacco) ; the dried leaves pressed into cakes, having becn previously moistened with treacle or sugar and water (Cavendish and Negrohead), used for chewing and smoking; the dried leaves moistened with treacle and water, beaten until they are soft, and then twisted into a sort of string (called Pigtail); the dried leaves and the dried stalks ground into a powder and baked, or roasted as it is called, used as snuff, which is variously scented to suit the different olfactory tastes; the dried leaves deprived of their midribs and wound into a sort of spindle-form, seldom more than three inches in length, known as cigars, and a variety in the form of cylinders cut straight at each end and thicker at one end than the other, known as cheroots. Besides these preparations for smokers there are cigarettoes or cigarettes, 
made by rolling up a very small quantity of cut tobacco in a small piece of paper, or, what is generally preferred, a piece of the leafy covering of the Indian corn : these are smoked the same as cigars, usually by very moderate smokers.

The varieties of tobacco found in commerce are very numerous, and are derived from various species of Nicotiana indigenous to Europe, Asia, Africa, and America. The following list comprises most of the sorts known.

American Tobaccos:-

Virginian, Maryland, and Kentucky, imported in hogsheads, the leaves tied into small bundles called hands, sometimes with the leaf entire, sometimes with the midrib removed: in the latter case it is termed "strips." These three varieties are all the produce of Nicotiana Tabacum; they are cultivated very extensively in the States after which they are named. Colour yellowish-brown.

Orinoko.-A less common sort, derived from Nicotiana macrophylla. Native of America.

Columbian.-Probably from $N$. Loxensis, a native of New Granada.

Brazil Leaf and Roll.-The roll tobaccos of South America are prepared by rolling or twisting the leaves into a kind of loose rope an inch or more in diameter; this 
rope is coiled up into cylindrical rolls of about two feet in length and one foot in diameter. Porto Rico, Puerta Cabello, Maracaibo, and Varinas Roll, are all most probably produced by the perennial tobacco of Buenos Ayres, $N$. glauca, and not improbably from other native species. Colour light browi.

Cuba, Yara, and Havana.-This tobacco, of which the fine Havana cigars are made, is the produce of the annual species, $N$. repanda, a native of Cuba; it is the $N$. lyrata of some authors. Colour dark brown.

Peruvian and Chilian.-Probably from $N$. andicola, a native of the Peruvian Andes.

\section{Asiatic Tobaccos:-}

East Indian and Manilla is produced from $N$. rustica, var. $\beta$, Asiatica. The $N$. rustica is a native of Europe, Asia, Africa, and America; there are several varieties of it, but the one indicated is that which is most generally cultivated in India: the leaf is much smaller than the common American species, and is ovate instead of lanceolate; one of the varieties is often cultivated in this country as a garden plant. Colour dark brown.

Persian or Shiraz.-This highly valued sort, occasionally received from Turkey, is produced by $N$. Persica; the 
leaves are long and lanceolate. The Shiraz tobacco is very celebrated; it is in yellow tough leaves, often much broken. Latakia.-This, which we also receive from Turkey, comes from the Turkish province of Isatakia, formerly the ancient Laodicea; it is produced by another variety of $N$. rustica. Latakia tobacco consists of the leaves together with the panicles of flowers and buds, with about four inches of the pedicels attached; the leaves and flowers appear to be laid in layers one upon the other to a considerable thickness and then pressed together, until they form compact hands, about the size of a man's head. 'The colour is a dark brown.

Chinese.-The author has met with two kinds of tobacco from China: one in small yellow ovate leaves of a bright yellow colour, not tied in harids, and not more than four inches in length ; the other in hands consisting of dark brown lanceolate leaves, eighteen inches long and very smooth. Neither are of common occurrence in this country; the former is probably a variety of $N$.rustica; the latter is undoubtedly $N$. Chinensis, a perennial tobacco of large growth.

European Tobaccos:-

Dutch and German are furnished by two or three species, especially $N$, Tatacum and $N$. rustica. 
TOBACCO.

Though cultivated in Africa, the tobacco of that country has taken no important position in commerce.

Nothwithstanding a high rate of duty payable upon importation, the consumption of tobacco in this country is immense. In 1850 the imports were $42,441,520 \mathrm{lbs}$; of this a very large portion was re-exported. The following statistics of its consumption are taken from a paper ' On the history and consumption of Tobacco,' by John Crawford, Esq., read before the Statistical Society, November 15th, 1852, reported in the 'Literary Gazette' of January 1st, 1853. The table "exhibits the rapid increase in its consumption during the last thirty years.

\begin{tabular}{|c|c|c|c|c|c|}
\hline Years. & Consumption. & $\begin{array}{c}\text { Duty } \\
\text { per lb. }\end{array}$ & Revenue. & Population. & $\begin{array}{l}\text { Consump- } \\
\text { tion 'per } \\
\text { head. }\end{array}$ \\
\hline $\begin{array}{l}1821 \\
1831 \\
1841 \\
1851\end{array}$ & $\begin{array}{c}\text { lbs. } \\
15,598,152 \\
19,532,841 \\
22,309,360 \\
28,062,978\end{array}$ & $\begin{array}{l}4 s . \\
3 s . \\
3 s . \\
3 s .\end{array}$ & $\begin{array}{c}£ . \\
3,122,383 \\
2,964,592 \\
3,580,163 \\
4,485,768\end{array}$ & $\begin{array}{l}21,282,960 \\
24,410,439 \\
27,019,672 \\
27,452,262\end{array}$ & $\begin{array}{c}\text { oz. } \\
11 \cdot 71 \\
12 \cdot 80 \\
13 \cdot 21 \\
16 \cdot 86\end{array}$ \\
\hline
\end{tabular}

"The total annual production of tobacco is estimated at 2,000,000 of tons, and would require half the British tonnage which 'enters inwards' or 'clears outwards' annually, to transport the same. The value, at $2 d$. per pound, would amount to $£ 37,000,000$ sterling." 
Conk (called commercially Corkwood).-The outer bark of the Cork Oak (Quercus Suber, Nat. Ord. Corylacea).

This very useful substance is formed by the tree between the outermost and innermost layers of its bark ; it consists of a peculiar cellular mass, the individual cells of which are distended with a curious grumous secretion, which hardens and dries, and forms the substance of the Cork. When the Cork Oak is nine or ten years old, the outer bark splits and the second layer grows, and increases very much in bulk by the constant secretion of the corky matter: this would fall off naturally in nine or ten years, but is usually removed when six or seven years old. The removal is effected by cutting a slit through the bark from the top of the trunk to the bottom, and a transverse one at each end; the cork will then easily peel off; it is afterwards removed, in large curled-up pieces, to properly prepared pits; here the sheets are piled up one upon another, and heavy weights are placed to flatten them down; water is then let into the pit, and the cork left to soak for a time, it is then taken out and dried, and retains its flatness. Its use in making corks for bottles is very generally known; it is also used for a variety of economic purposes, amongst which cork soles for shoes, making life-buoys, etc. The imports amount to 2520 tons, an enormous quantity of so light a material. 
Ricf. Paper.-Another cellular substance, though very different from the last. This beautiful material has given rise to much discussion; the common opinion was that, as its name implied, it was made of rice; the slightest microscopic examination however proved that it was a fine cellular tissue. It has been attributed to many plants, but it is now, through the indefatigable perseverance of the officers of the Kew Gardens, decided to be the produce of Aratia papyrifera (Nat. Ord. Araliacea), called in China, Taccada. The pith, which is about an inch and a half in diameter, is freed from the external parts of the stem, and then pared in the same way the ancients employed in preparing their paper from the pithy stem of the papyrus rush (Papyrus antiquorum). After the mass has been carefully pared to the centre, it is flattened out and pressed by heavy weights placed upon it; when thoroughly dried under pressure, it retains its perfect flatness. Its use is chiefly for watercolour paintings of flowers, fruit, and insects, which have an exquisite effect upon rice-paper. It is also employed for a few other ornamental purposes.

Amadou, German Tinder.-This cellular substance consists of slices cut from the large parasitic fungus Boletus igniarius (Nat. Ord. Fungi): it grows in large masses upon 
the oak. When first obtained, it is rather hard, but by beating it with mallets it becomes soft, feeling very much like chamois-leather. It is used as tinder, for which it is admirably adapted, and also in surgery as a styptic. One or two other fungi are used for the same purposes, under the name of Amadou. Polyporus fomentarius is the true Amadou : it is used in India, and also by the Laplanders, who place great value upon it as a styptic.

VEGETABLE IVoRY.-This remarkable substance, which so closely resembles a product of the animal kingdom, is the hardened albumen of the nuts of a species of Palm, Phytelephas macrocarpa. (Plate X. fig. 48. Fig. 49 represents the nut about half the natural size, with the outer shell partly broken; and figure 50 is a section of the same showing the relative proportion of the ivory and the position of a small cavity which always exists in the centre.) These nuts in commerce usually go by the name of Corosso nuts. How this name originated is a mystery, as the Indians call the palm by the names Pullipunta and Homero; the native Spaniards call it Palma del Marsil and Marsil vegetal. The nuts are enclosed in large capsules, about twenty inches in circumference, containing many of the seeds or nuts. Owing to the extreme shortness of the caudex, or stalk, of 


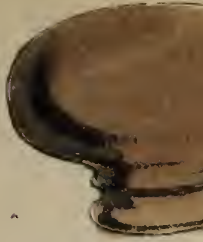

(1)
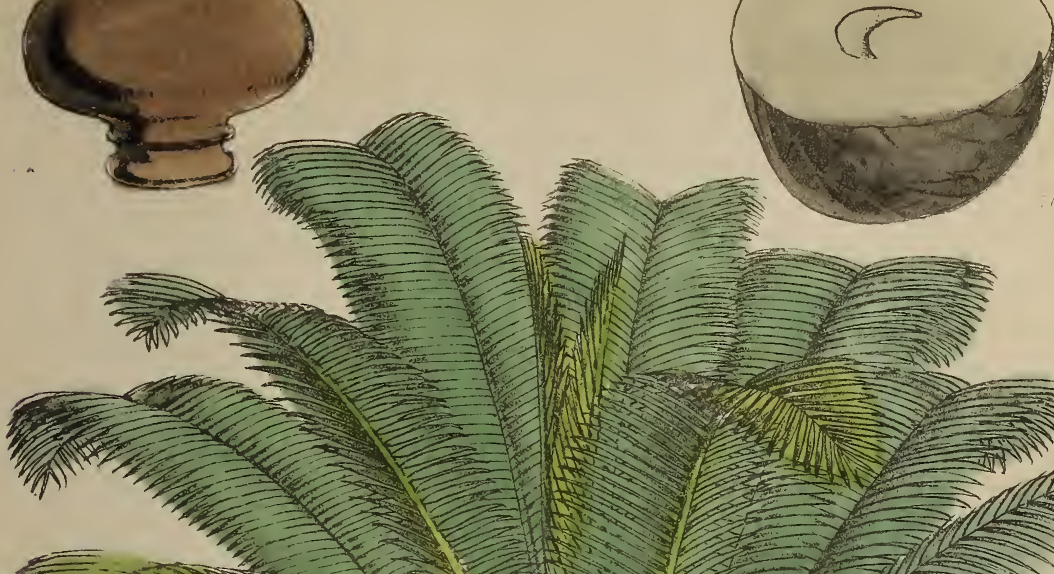

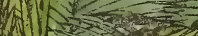
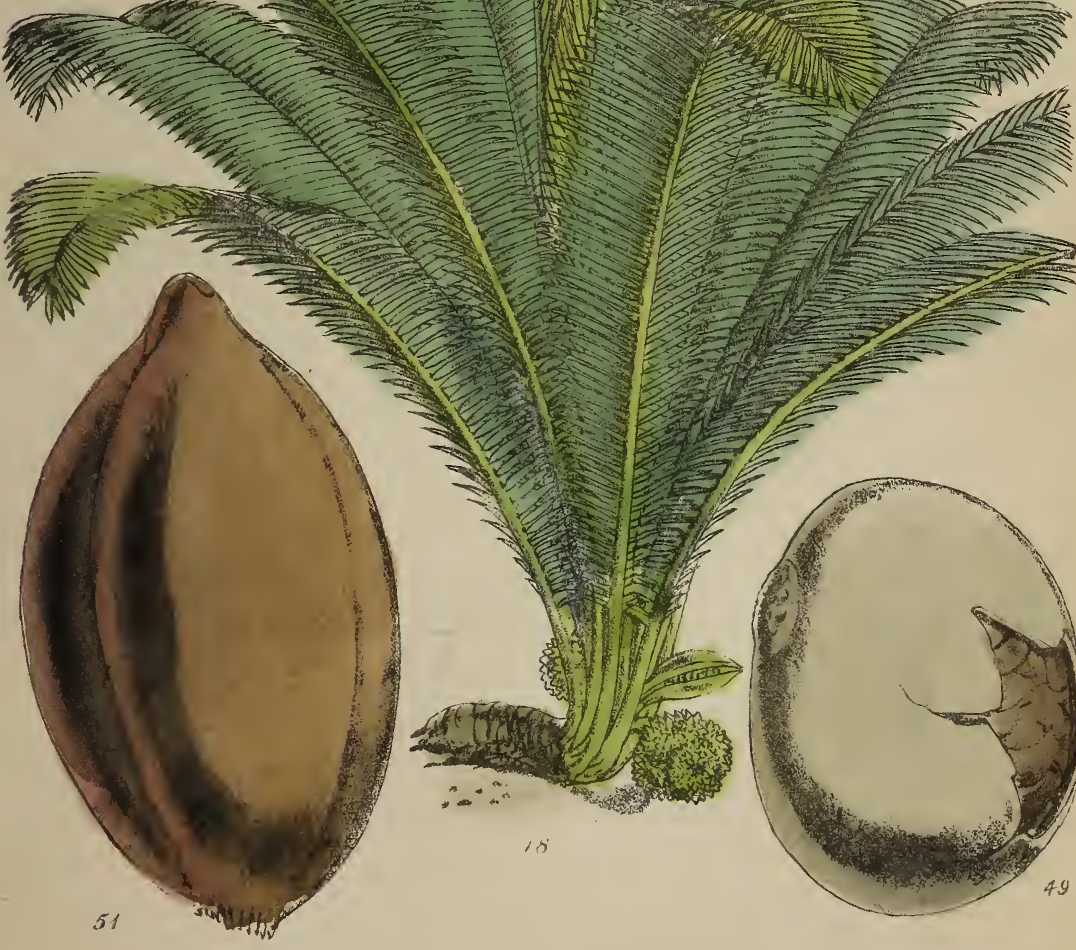

48 bicutrable how f'atur

14) Vegetatle Ivory Nut

50 Section of $D^{\circ}$. 51. Coquilla Nut. 53 The Nut turned 

this fine palm, the large capsules lie on the ground, as seen in the Plate, whilst the majestic tuft of pinnated leaves, twenty feet in height, rises like a gigantic plume of feathers. 'The capsules are said to resemble negroes' heads, and are called by the natives, Cabeza de negro. The Vegetable Ivory Palm is a native of the low valleys of the Peruvian Andes. We are indebted to Sir William Hooker for our knowledge of this fine palm, and for proving it to be the produce of the Corosso nuts; a very interesting article will be found upon this subject in the 1st volume of 'Hooker's Journal of Botany,' 1849. They are used extensively by the turners in making small trinkets to imitate ivory. About 80,000 of the nuts were imported in 1852 .

Coquilla Nurs.-The seeds of another Palm, Attalea funifera (Plate VIII. tig. 40), previously alluded to in speaking of Piassava. In Plate X., fig. 51 is a Coquilla nut, and fig. 52 a parasol handle turned out of one of these nuts. The seed of the Attalea was known long before the palm which produces it, and as the seed clearly indicated a cluse affinity to the Cocoa-nut, it was called by Gærtner, Cocos lapiclea, and by Targioni Tozzetti, Lithocarpus cocciformis. Coquilla nuts are often three inches in length: they have a small cavity in the centre, in which the seed is found; 
the shell is thick and extremely hard and brittle, taking a very fine polish; they are used chiefly in the manner indicated by fig. 52, and for making the small knob-handles of cabinet drawers. About 300,000 nuts were imported in 1852.

ARECA Nuts. - The fruit of another palm. They are inclining slightly to pear-shape, about the size of a large cherry, very liard, and externally not much unlike some of the inferior nutmegs; the only use to which they are applied in this country, is for making tooth-powder, for which purpose they are first converted into charcoal and then powdered; only a very small number is imported. They are the seed of Areca Catechu (Palmacere), and constitute the celebrated Betel Nuts of India.

Juniper Berries.-The fruit of the common Juniper (Juniperus communis, Nat. Ord. Conifera). (Plate XIX. fig. 101.) These berries are imported in considerable quantities from the North of Germany, Holland, and other places, for flavouring the gin of this country. More than 200 tons per annum are usually imported.

Tonquin, Tonga, or Tonca Bean.-The seeds of Dipteryx odorata (Nat. Ord. Leguminosa). The pods of this plant only produce one seed in each: this seed or bean is 
an inch in length, shaped somewhat like a thin almond, covered with a shining black skin, and of an agreeable and powerful odour, resembling newly-made hay; the odoriferous principle resides in a substance called courmarine. It is a native of Guiana, and is used almost only for scenting snuff; a few hundredweights are imported annually.

Patchouli or Pucha-Pati. - A herb named Pogostemon Patchouli (Nat. Ord. Labiatc). (Plate XVI. fig. 84.) The dried tops with leaves and flowers are imported in bundles about one foot in length; they yield, by distillation, an essential oil, in which form the perfume exists, and, by digestion in weak alcohol, a tincture called Essence of Patchouli or Patchouly. This peculiarly-scented vegetable product is only used in perfumery, but the odour it yields, though delightful to many, is to other's very offensive. It is imported from India, in chests and half-chests, the former weighing $110 \mathrm{lbs}$. each. In the description of the Patchouli plant in 'Hooker's Journal of Botany,' a writer in the 'Gardeners' C'hronicle' is quoted, who states that the characteristic smell of Chinese Indian Ink is owing to an admixture of patchouli in its manufacture. This is however manifestly erroneous : the Sepia, from which the Indian ink is manufactured, has naturally a strong musky odour, so 
much so, that those fæces of the whale which constitute the much-admired and valuable perfume called ambergris are believed to originate solely from the animal feeding upon the Sepia, the comminuted bones of which are constantly found in ambergris.

OrRice or Iris Root.-The root of the Florentine Iris (Iris Florentina, Nat. Ord. Iridacea). (Plate XVI. fig. S3.) This vegetable production, which is only used in perfumery, is the rhizome or underground stem of the above species of Tris, and probably also of I. pallida. It comes from Italy, in flattened white pieces of very irregular shape, and spotted with brownish spots; these are the points from which the fibrous roots have been removed. Orrice root possesses a beautiful violet odour, and is used principally in the perfumed preparation of wheai-starch called Violetpowder. Above five tous are annually imported.

Calamus Root is the rhizome of the Sweet Flag, Acorus aromaticus (Nat. Ord. Acoracea).

This plant has a most extensive geographical range, being found in Europe, Asia, Africa, and North America. The bulk of that which furnishes the supply of our markets is from the banks of the Norfolk rivers, where it is indigenous and very plentiful; it is however occasionally im- 



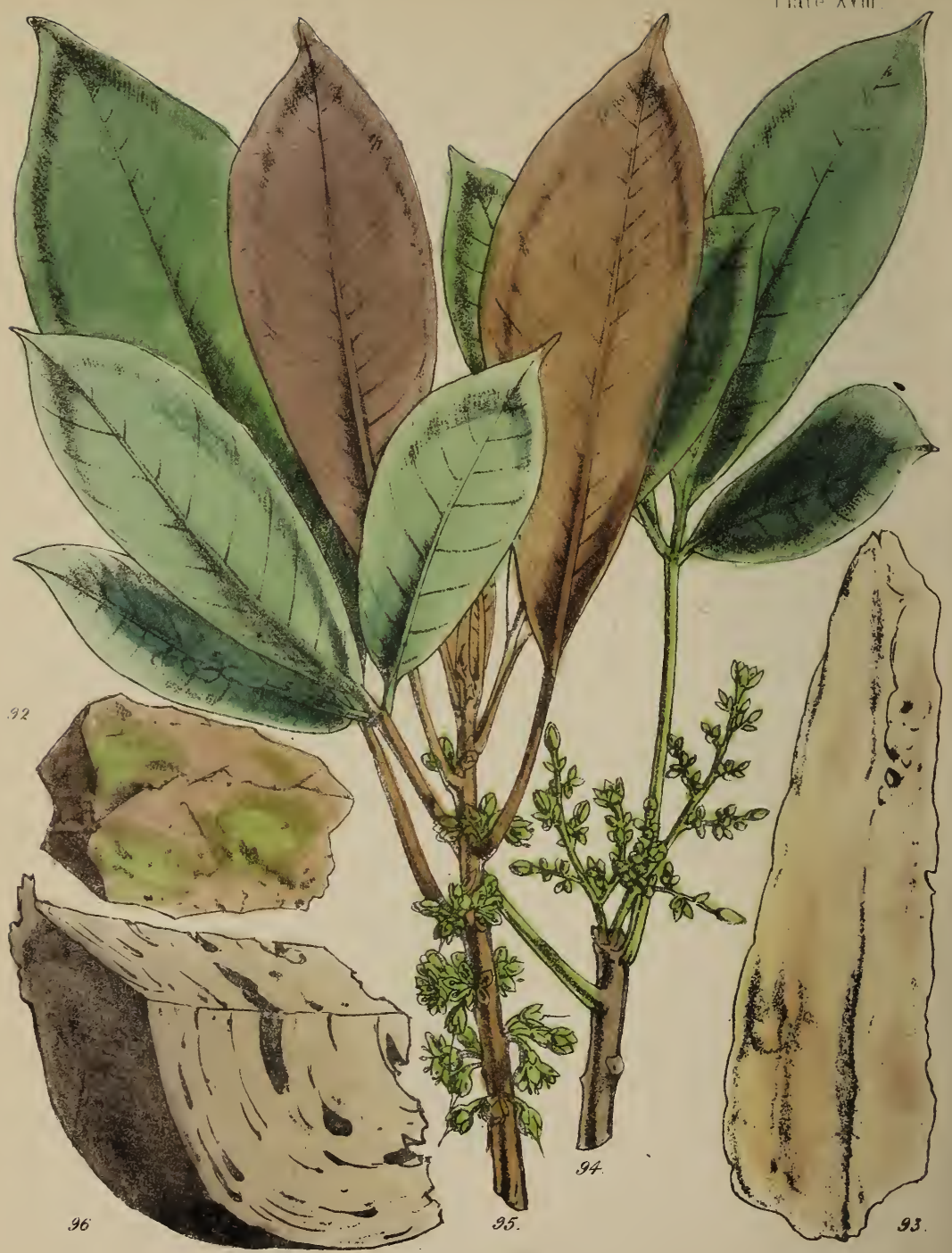

94. India Ruitber Plant 
ported from Hamburg and from the Italian ports. The foreign article usually has the rind pared off. Calamus root, or Calamus aromaticus as it is usually called, is in flattened pieces, about three-quarters of an inch broad and five or six inches in length, of a yellowish-brown colour; this rhizome is also marked with scars from which the leaves have been removed, and by spots, below where the roots existed. Its essential oil is used in perfuming snuffs. The root is much used in the adulteration of ale, by the brewers and publicans; it is also used by perfumers.

Gum Benzoin or Benjamin. (Plate XVILI. fig. 92.)A gum-resin used chiefly in perfumery. It is produced by the Benjamin-tree, Styrax Benzoin (Nat. Ord. Styracea), a very large tree, indigenous to Sumatra, Borneo, Siam, and Java.

The gum exudes from incisions purposely made in the stems, and is of different qualities according to the age of the trees. We receive it either in masses or tears: the masses are fragments of the solid block into which the Benzoin is run in the chests, and is a mixture of red and white patches, having a resemblance to coarse red granite; the tears are usually nearly white, and of a very fine quality. It forms an ingredient in the incense used for burning, and in some 
few medicinal preparations. About 10 tons were imported in 1853, from the East Indies.

Gum Styrax or Storax.-Another odoriferous gumresin, the produce of Styrax officinale (Nat. Ord. Styracee).

There are several varieties of this gum, all the produce of Turkey in Asia, where the gum exudes naturally through punctures made in the bark by insects; the bark is also cut for the purpose. It is either liquid or solid; the former is thicker than treacle, of a greyish colour and agreeable vanilla odour; the solid is in large cakes of a reddish-brown colour. It is very easily broken, and consists of a coarse sawdust-like powder of reddish-brown colour. It contains about four-fifths of sawdust, and it appears most probable it is nothing more than the liquid storax mixed with sufficient sawdust to divide it thoroughly and so dry it, after which the saturated sawdust is pressed into cakes. It is seldom used except by perfumers, and is but very rarely imported.

Agra-Agra, Ceylon Moss. Plocaria candida or Fucus amylaceus. The former name has been lately adopted. (Nat. Ord. Algce.)

This seaweed is occasionally imported in considerable quantities for the purpose of making a jelly for dressing silks. It is in the form of thin, very much branched pieces; the 
branches are roundish and very rough, being covered with small pointed tubercles; it is of a yellowish colour and so gelatinous as to be semi-transparent; it tastes strongly, when imported, of sea-salt, and has the usual odour of seaweeds. It forms a considerable article of food in India, and is said to furnish the material for the edible birds'-nests of China. When well washed and then soaked in pure water, it swells considerably and becomes transparent; in this state it is boiled in syrup and forms a delicious preserve, which is sometimes imported in jars, similar to those which contain preserved ginger.

Carrageen, or Irish Moss. Chondrus crispus. (Nat. Ord. Alga.)

This is another seaweed which yields an abundance of gelatine, and is used in the manufactories for dressing silks, etc.; it is also extensively used in feeding cattle, and to make a light nutritive jelly for invalids. It is in broadish fronds, resembling pieces of yellow parchment much crisped or curled at the edges. It contains 79 per cent. of vegetable jelly. It is occasionally imported from Northern Europe, but enormous quantities are furnished from the Trish coasts. Teazels.-The dried heads of the Fullers' Teazel, Dipsacus fullonum (Nat. Ord. Dipsacece). 
The fullers' teazel produces a large conical composite flower-head, which is persistent after the flowers have died; it is covered with hard, stiff, sharp-pointed bracts, the points of which are bent in the form of a hook; these cones are about two and a half inches in length, and one inch and a half in diameter at the base; they are used for raising the nap on woollen cloth, for which purpose they are so admirably adapted, that no invention has yet been found to supersede them entirely. When used, they are cut into halves or quarters, and a great number are fixed in a frame with the hooked bracts outwards, so that a large surface of these minute claws is presented; the frame is then made to move over the surface of the cloth until the little sharp hooks of the teazels have scratched up the required nap; large quantities are imported from Hamburg and Holland, besides which the teazel is extensively cultivated in many parts of England.

Dutch Rushes. Equisetum hyemale. (Nat. Ord. Equisetacea.)

This curious vegetable production is found abundantly in the low boggy grounds of Holland, whence it is occasionally exported; it is also found in similar localities in England. Its stem, which is about a foot in height, is covered 
CANES.

with a skin so full of silica, that it is occasionally used to polish furniture, woods, and metals. Formerly it was of great importance for that purpose, but the invention of sand and emery papers has almost superseded this natural file.

Canes.-Under this general designation the stems of several different plants are imported for various purposes, chiefly as walking-sticks. The walking-canes are principally-

The Malacca Cane (Calamus Zalacca, Nat. Ord. Palmacea), which are highly prized; they are of all thicknesses up to an inch in diameter, jointed like the common rattan, but with the joints so far apart that a good walking-cane can be made of a single internode; these canes are of a rich reddish-brown colour, and as shining as if varnished. The brown tint is communicated by a process of smoking. They are imported from China and the East Indies.

Partridge Canes are the stems of some small Palm, with the exterior removed, and the hard wood polished; they resemble sticks of porcupine-wood, and are chiefly used as handles for umbrellas, etc.

Penang Lawyers are also the stems of a species of Palm, but which one is a matter of uncertainty; they are said to be produced by a species of Calamus. 
Several of the walking-canes are produced by plants belonging to the Natural Order Graminacea, or the Grasses: thus the Bamboo, which is of almost universal application, though very seldom used for the purpose above indicated, is a species of grass, Bambusa arundinacea, often fifty or sixty feet in height; and there are several resembling it, only differing in size, which are only used as walking-canes; for instance, those called Whangees, White and Black Bamboos, Fluted Bamboos, Jambees, etc.: we are however quite ignorant of the species which produce them.

Under the name of Reed Cane, the culm or stem of a grass is largely imported from New Orleans, for the purpose of making weavers' shuttles, etc.; they are probably from Arundinaria Schomburgkii, and are often forty feet in length.

The Bamboo is of infinite use to the inhabitants of the East Indies, and especially China, who adapt it to an infinity of purposes; they even make ornamental clothing by stringing together very small lengths of the small petioles of the beautiful narrow lanceolate leaves; they also build their huts and make every article of their furniture of this useful cane, which thrives in the East with extraordinary luxuriance. 


\section{7}

\section{DIVISION IV.}

\section{MATERIA MEDICA.}

\section{CHAPTER XIII.}

\section{MISCELLANEOUS MEDICINAL PRODUCTS.}

In a work professing to be a popular history of the economic productions of the vegetable kingdom, it would be entirely out of place to enter into a description of all those vegetable materials which constitute the remedial agents used in pharmacy. Indeed they are so numerous that the present volume would prove insufficient for the slightest sketch of their qualities and characters.

There are a few however which are of such familiar use, that a selection of these, and such others as are possessed of some interest, will perhaps be acceptable to the reader. 
Several Gums were omitted from the chapter on those products, because their use was solely medicinal; they will now therefore be mentioned.

Gum Asaferida.-A gum-resin which exudes from incisions made in the root of Ferula Asafotida (Nat. Ord. Umbelliferce).

Much learned discussion has taken place upon the probability of this plant being in use amongst the ancients under the name of laser, which it is supposed has been changed to asa, or, as it is called by Avicenna, assa.

This Ferula is a native of Persia; it has very large taproots, similar to but much larger than the common parsnep. In order to obtain the gum-resin the cultivators remove the earth from the upper part of the root, and then cutting off the crown, from this excision the gum-resin oozes as a milky juice, which however rapidly changes colour and hardens upon exposure to the air; it is scraped off from time to time; and when fully hardened in lumps, it has a red colour and disagreeable smell, resembling garlic. About 3000 lbs. were imported in 1852. Usually it is in lumps, or run in one mass into a case; sometimes it is in tears, which are yellowish-white, and varying in size from a pea to a walnut. 
Gum Sagapenum-is another gum-resin, obtained in a similar manner from a species of Ferula, which has not yet been correctly determined. It occurs both in tears and in mass; the former is in small brownish-yellow tears adhering together so as to form masses. The mass sagapenum is soft and tough, and of a dark yellowish-brown colour. This gum has a slight smell of onions. The quantity imported is small.

Gum Galbanum.-A gum-resin which exudes from incisions made in the stalk of Galbanum officinale. (Nat. Ord. Umbellifera.)

The chief interest attached to this gum arises from its rarity, the uncertainty of its native locality, and its great antiquity, as an esteemed vegetable product. Thus it is mentioned by Moses in Exodus xxx. 34: "And the Lord said unto Moses, Take unto thee sweet spices, stacte, and onycha, and galbanum; these sweet spices with pure frankincense: of each there shall be a like weight." It is supposed, without any certainty, to be a native of Syria, of Persia, and of Arabia. It is either in brownish-yellow, semitransparent tears, round, and about the size of peas, or else it is in agglutinated masses consisting of the tears probably of an inferior quality, and usually of a darker colour, less 
translucent, and much mixed with seeds, stalks, and other foreign substances. It has a fragrant balsamic smell, but is not very agreeable; its use is principally as a constituent of plaisters.

Gum Opopanax.-A resinous exudation obtained from - incisions in the roots of Opopanax Chironium (Nat. Ord. Umbelliferce). It is a reddish-yellow gum, which occasionally, but rarely, comes from Italy, Sicily, and Greece; it was known to the ancients, who employed it in pharmacy.

Gum Ammoniacum.-The gum-resin of another Umbelliferous plant-Dorema ammoniacum.

This gum is the produce of Persia; it oozes forth from the punctures made in the plant by a species of beetle which infests it. Sometimes it is in yellowish-white tears, but more generally in masses formed by the agglutination of these tears; the smell is disagreeable. Though produced in Persia, we receive our supply, which is considerable, entirely from India.

Gum Scammony.-A gum-resin procured by making an incision in the upper part of the large perennial roots of the Convolvulus Scammonia (Nat. Ord. Convolvulacea), for which purpose the earth is removed from the top of the root. (Plate XVII. fig. 90.) 
GUM MYRRH.

We usually receive Scammony from Smyrna, in the form of small compact cakes about an inch thick and three or four inches in diameter. It is of a dark greenish.black colour, with a dull surface and a remarkable cheesy smell. But scammony, owing to the adulterations practised upon it by those who collect it, is so varied in appearance that a very long description of all the varieties would be necessary to perfect its history. We receive between 2000 and $3000 \mathrm{lbs}$. per annum.

Gum Elemi, or Elemi, is a peculiar resin, the history of which is involved in obscurity. The Dutch furnish the whole supply of this resin, which is consequently thought to be the product of one of their colonies, but both its origin and the locality whence it is brought are, with the characteristic jealousy of that people, kept entirely secret. It is in masses, having a sweet balsamic smell, and a greenish and yellowish-white colour. A few hundredweights only are imported.

Gum MyrRH.-This gum-resin exudes naturally from the stem of Balsamodendron Myrrha (Nat. Ord. Amyridacea), a small shrub growing on the coast of Abyssinia, and called Kerobeta by the inhabitants.

Myrrh is frequently mentioned in the Scriptures, even 
as early as Genesis xxxvii. 25, where we find the Ishmaelites, to whom Joseph was sold by his brethren, were merchants dealing in "myrrh, balm, and spicery;" its name in all probability is derived from the Hebrew word Mur, which signifies bitter, - a name very expressive of its bitter taste. It has always been highly esteemed, on account of its sweet balsamic odour and presumed medicinal virtues. Two kinds are imported, one from the East Indies, the other from Turkey; the latter is the better variety. Myrrh is in small masses about the size of a walnut, sometimes larger, very irregular in shape, and of a reddish-brown colour (darker in the Fast Indian variety), slightly translucent, and appearing to be covered with yellowish-brown dust. About 15 or 16 tons are annually imported, the greater portion from the East Indies.

Manna.-A concrete juice which exudes from the branches of the European Flowering Ash, Ornus Europaea (Nat. Ord. Oleacea). (Plate XVIII. fig. 93.) It is usually produced by making incisions in the stem and branches of the tree; it is a peculiar kind of sugar, called Mannite; when it first oozes from the longitudinal incisions it is a yellowish-white liquid, which concretes on the bark, and is removed in long strips, called flakes; there are other varieties, but Flake 
Manna is the best. All we receive comes from Sicily in boxes, and amounts to about 11,000 lbs. per annum.

Aloes. - The juice of the leaves of various species of Aloe, principally $A$. vulgaris, $A$. Socotorina, and $A$. spicata. (Nat. Ord. Liliacea.)

The juice of the aloe-leaves is either expressed or drained out, after which it is boiled until it begins to thicken, when it is poured into gourds or calabashes, and other convenient packages, and hardens into a compact black substance, having an aromatic smell, but an intensely bitter taste.

There are several kinds distinguished in commerce, asSocotorine Aloes (the best) produced by $A$. Socotorina. Barbadoes Aloes (fine quality)

Cape Aloes (very inferior)

Hepatic Aloes (inferior)

Mocha Aloes (the worst)

Indian Aloes (quality variable)

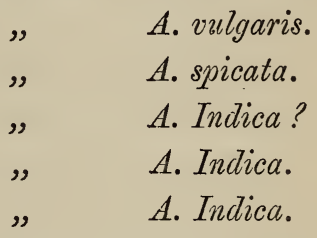

About 120 to 130 tons of Aloes are annually imported.

Liquorice Root.-The large tap-roots of the Common Liquorice (Glycyrrhiza glabra: Nat. Ord. Leguminosa). (Plate XVIl. fig. 91).

This well-known vegetable product was equally familiar to the ancients, who also used it medicinally. The root is 
rarely imported, a considerable quantity being grown for medicinal purposes in various parts of the kingdom. We however receive from Italy very large quantities of the extract of the root, either made into short sticks, and called Spanish Liquorice, or Liquorice Juice; or else in the form of an extract run into boxes of about two hundredweights each; the latter article is the purest. 560 tons were imported in 1850. Much of this large quantity is used by the brewers in the manufacture of porter.

CAMPHоR.-A peculiar vegetable principle contained in many plants, but the Camphor of commerce is derived from Camphora officinarum (Nat. Ord. Lauracea). (Plate XVII. fig. 85.)

Camphor exists chiefly in the wood of the tree, and being volatile, is easily distilled from it by means of heat, and is condensed in an earthen receiver. The crude or unrefined camphor of commerce is obtained from China and Batavia; it is in the form of a crystalline powder, of a dirty white colour, and resembling some of the white varieties of unrefined sugar; it is refined by re-distillation. The imports exceed 200 tons annually.

Nux Vourca. - The seeds of Strychnos Nux-Vomica (Nat. Ord. Apocynacea). (Plate XVI. fig. 86.) 
RHUBARB.

These poison nuts contain the peculiar vegetable principle called Strychnine, which is remarkable for its powerful effect on the nervous system of animals, and for its intense bitterness; it is in consequence of this latter quality it has lately been so much an object of interest, owing to statements having been made that it was used to give a flavour to the common beverage called bitter ale. This has been contradicted by those most interested, nevertheless the most suspicious point has not been cleared up. In 1840 only 550 pounds of Nux Vomica were imported, whereas in 1852 nearly as many tons reached the English markets. The seeds are about the size of a shilling, twice as thick, and have a silky appearance; they are of less thickness in the middle than at their edges, and have a small point or umbilicus in the centre of the concave side, one surface being more concave than the other. Their colour is a kind of fawn or light drab. Nux Vomica is imported from Coromandel, Ceylon, etc.; it is much used as a poison for rats and mice.

Rhubarb.-The dried roots of some species of Rheum. (Nat. Ord. Polygonacea.)

No drug in the whole Materia Medica has given rise to more discussion as to its origin than the medicinal Rhubarb. 
There are two distinct varieties in ordinary commerce, known as East Indian and Turkey, but there are others in the market; properly the East Indian should be called $\mathrm{Hi}$ malayan, and the Turkey Russian; there are besides the Dutch trimmed, Chinese, English, and French. The species of Rheum supposed to yield them are $R$. undulatum, $R$. palmatum, $R$. compactum, and $R$. Rhaponticum. About 140 tons is the annual supply. 'The roots are cut into pieces of various size and shape, but usually of the bulk of an orange; the outer bark is peeled off, and the lumps are apparently trimmed with a file; very often they are perforated with large holes, which have been made for the purpose of stringing them up to dry.

JALAP.-The dried tubers of Exogonium Purga (Nat. Ord. Convolvulacea). (Plate XVII. fig. 89.)

This valuable medicine has been known in Europe ever since 1733, when it was introduced from Mexico, its native place, by Dr. Ilouston; it derives its name from a place named Xalapa, where it is most abundant. Until lately it was supposed to be derived from a species of Convolvulus, which, under the name of $C$. Jalapa, has long been cultivated in the botanic gardens of Europe as the true Jalap plant ; it is now proved to be an Exogonium, a genus distinguished from 

Ipomcea and Convolvulus chiefly by the stamens being protruded out of the tube of the corolla. It is a beautiful climbing convolvulus-like plant, with delicate pink flowers; its stem is perennial, but very thin, and forms in the ground a tuber of an oval figure thin at each extremity, where the stem and roots are given off; it reaches the size of a small turnip, but the largest tubers are rarely selected; they become much smaller by drying; externally the tubers are of a dark umber-brown colour and much wrinkled. The imports are nearly 150 tons per annum. A spurious kind of jalap is often found in the markets under the name of Male-jalap, or He-jalap ; it consists evidently of pieces of a much larger tuber, much coarser, but in general appearance not unlike the true species; it is produced by Ipomcea Orizabensis (Convolvulacea).

- Senna Leaves.-Dried leaves of several species of Cassia (Nat. Ord. Leguminosa).

There are several qualities of Senna in commerce, and it is thought they are all derived from different species. The principal commercial kinds are Aleppo, Alexandrian, and East Indian or Tinnevelly Senna. They are supposed to be yielded by the following species:-Aleppo, by Cassia obovata, a perennial herbaceous plant, a native of Northern Africa, but 
now cultivated in southern Europe and the West Indies ; Alexandrian, by several species mixed together, as $C$. obovata, C. acutifolia, C. Attriopica, and almost invariably with the leaves of a plant belonging to the Natural Order Asclepiadacea, called Cynanchum Argel;-and Tinnevelly, by $C$. elongata, an annual species, which, being carefully cultivated and kept quite free from mixture of other species, is the most highly prized. The same species yield several other varieties, produced in other localities. The Senna Cassias all produce yellow flowers, which, though belonging to the Leguminous Order, have no general resemblance to peashaped flowers; the reader must therefore refer to Plate XVII. fig. 87, and will derive a better idea from Mr. Fitch's beautiful drawing than from the most elaborate description. The quantity of senna imported from all parts, in 1852, was about 257 tons.

The long round black pods, imported under the name of Cassia-fistula, are seed-pods of an allied species, Cathartocarpus Fistula (Nat. Ord. Leguminosa), a tree found in China and the East Indies.

Peruvian Bark, Jesuits' Bark.-The dried bark of various species of the genus Cinchona (Nat. Ord. Cinchonacea). (Plate XVII. fig. 88.) 
The extreme value of the Peruvian Cinchona barks in pharmacy has caused their history to be discussed more than that of any other remedial agent; the discussion respecting Peruvian Bark has moreover been greatly increased by the mystery which hangs over its early history. Whether it was known to the Indians prior to the discovery of America, or first used by Europeans afterwards, is not clearly proved. One tradition says it was discovered by an Indian, who was dying from fever on the bank of a river; in the agony of thirst he crawled to the water with a piece of bark which he had stripped off the tree against which he had been leaning, and used it as a scoop to raise the water to his lips; the bitter infusion thereby made, so wonderfully revived him that he recovered, and made known the value of Cinchona bark. The absurdity of this tale is apparent to all who are acquainted with the effects of the bark. Geoffroy says it was known to the Indians, but was by them kept a secret, until one of them, in a fit of gratitude for some benefit received, imparted it to the Governor of Loxa: this statement also is from many circumstances incredible. It received the name of Cinchuna from the Countess of Cinchon, who in 1638 was wife of the Viceroy of Peru; and hence also the powdered bark received 
the name of Pulvis Comitissa, or Countess's Powder; its value was made known to the natives of Europe chiefly by the agency of the Jesuits, whence it also received the name of Jesuits' Bark.

The value of the Cinchona barks is now known to depend entirely upon the presence of two peculiar chemical principles, called Quinine and Cinchonine, which are extremely effective in febrile diseases, especially those which are intermittent.

The Cinchonas are trees of moderate size, often not more than twenty feet, and rarely exceeding twice that height; they bear a profusion of small white or roseate tubular flowers, and have handsome shining lanceolate leaves placed oppositely on short petioles. The species which are valuable for their bark are numerous, the following are however the principal ones:-

C. Condaminea, yielding Crown or Loxa Bark.

C. micrantha,

C. ovata,

C. purpurea,

C. (species?)

C. (species?)

These barks are usually in the form of quills, some sorts
Huanuco, Grey, or Silver Bark. Ash Cinchona.

Rusty or Huamalies Bark.

Calisaya, or Royal Yellow Bark.

Red Bark. 
not thicker than the little-finger, others nearly as thick as a man's wrist; other sorts are in flattish pieces, and all are of various lengths, seldom exceeding two feet. They are usually imported in packages called serons, made of dried cow-hides. The quantity imported annually is from 80 to 90 tons; but much difficulty exists in ascertaining the exact amount, as in the Board of Trade returns it is, strange to say, mixed up with tanners' barks.

CASTOR OiL.-A fixed oil obtained by expression from the seeds (Plate XVI. fig. 82) of Ricinus communis, or Palma Christi (Nat. Ord. Euphorbiacea).

This oil is produced in great abundance both in India, its native country, and in America and the West Indies. Its utility as a medicine has been known from the most remote ages. The seeds have been found with Egyptian mummies in sarcophagi. The Greeks called it Croton, a name now applied to a closely allied genus; the Romans, remarking the striking resemblance in the seeds to the vile insects called ticks, which infest living animals, especially the dog and sheep, called it Ricinus, their name for the tick.

The Palma Christi is a very large herbaceous plant with handsome palmate leaves when grown in temperate climates, but it attains a larger size and acquires a woody stem 
of considerable bulk in the tropics; and although with us an annual, bearing seed and dying within a year, yet in India it is perennial. Castor Oil is very largely imported; nearly 500 tons is now the annual supply.

CASCARILla Bark is the bark of a tree, Croton Eleutheria, of the same Natural Order as the last (Euphorbiacea).

It is produced in the Bahama Islands; it is in small quills and fragments of quills, rarely more than two or three inches in length, and of an ash-grey colour. Besides its medicinal properties, which are tonic, it is used in fumigations, giving off a remarkably sweet musky odour in burning. It is often called Sweet-wood Bark. About 10 or 12 tons are imported annually.

Cardanoms. - The ripe capsules or fruit of Elettaria Cardamomum. (Nat. Ord. Zingiberacea.) (Plate XVI. fig. 81.)-Cardamoms were described in the chapter on Spices; their chief use however is medicinal, as carminative and aromatic. The sorts usually employed in medicine are the Malabar Cardamoms, of which three varieties occur, distinguishable chiefly by their size : they are termed shorts, sluort-longs, and long-longs: the lucidity of these commercial names will doubtless please those who quarrel with scientific phraseology. 


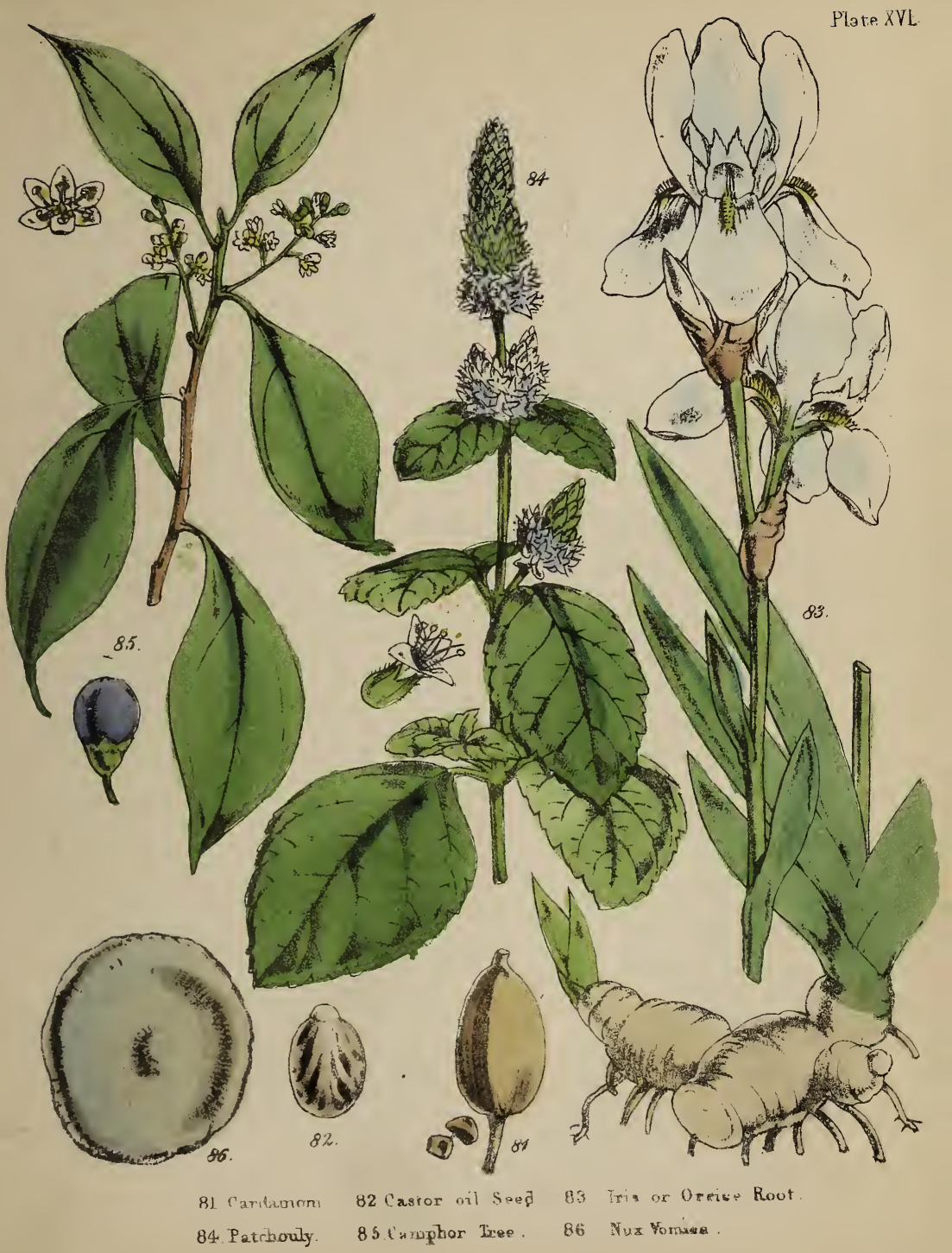



OPIUM.

OpIum.-The juice which flows from incisions made in the unripe capsules of the Opium Poppy, Papaver somniferum (Nat. Ord. Papaveracea), collected, dried, and formed into a mass.

The opium of commerce consists principally of two kinds, East Indian and Turkish; the latter is esteemed most highly. In India the Poppy is largely cultivated for the production of opium. Dr. Joseph Hooker describes the poppy-fields as resembling green lakes studded with white water-lilies. His description of the opium culture in India is the best account we have of the process; he says-

"The East India Company grants licenses for the cultivation of the poppy, and contracts for all the produce at certain rates, varying according to its quality.

"The poppy flowers in the end of January and the beginning of February, and the capsules are sliced in February and March with a little instrument like a saw, made of three serrated plates tied together; from the incisions made by this instrument the opium oozes out as a milky juice, which as it dries becomes a soft brown sticky paste ; each morning this paste is scraped off by means of small shells, and collected into jars, the contents of which are afterwards made into balls of about half a pound weight; 
these are often coated with the seeds of some species of Rheum (or rhubarb plant); the balls are packed into chests, and exported to other countries."

The employment of opium as a narcotic, especially in the preparation of laudanum, is well known, and very large quantities are brought to this country : in 1852, 51 tons were imported; this will be considered an enormous quantity, when the mode by which it is produced and collected is considered.

To attempt to proceed further with the account of the productions used in medicine would necessitate the introduction to this chapter of matters interesting only to the pharmaceutist; those already mentioned constitute all the Materia Medica likely to afford interest to the general reader. 


\section{DIVISION IV. \\ CONSTRUCTIVE MATERIALS.}

\section{CHAPTER XIV.}

\section{BUILDING AND FURNITURE WOODS.}

"And forth they pass, with pleasure forward led, Joying to hear the birds' sweet harmony, Which therein shrouded from the tempest dread, Seem'd in their song to scorn the cruel sky. Much can they praise the trees so straight and high, The sailing Pine, the Cedar proud and tall, The vine-prop Elm, the Poplar never dry, The builder Oak, sole king of forests all, The Aspen good for staves, the Cypress funeral.

"The Laurel, meed of mighty conquerors And poets sage, the Fir that weepeth still, The Willow worn of forlorn paramours, The Yew obedient to the bender's will, The Birch for shafts, the Sallow for the mill, 
The Myrrh sweet bleeding in the bitter wound, The warlike Beech, the Ash for nothing ill, The fruitful Olive, and the Plantain round, The carver Holm, the Maple seldom inward sound."

IN attempting to give the history of woods used in the construction of buildings, ships, and furniture, many diffculties arise, owing to the profound ignorance which prevails amongst all classes respecting the origin of the greater number of the woods of commerce. The varieties brought to this country are so numerous that their names alone would form an extensive catalogue; but even in that form we have no really reliable work of reference except the Illustrated Catalogue of the Great Exhibition, in which we find the admirably classified lists of Mr. W. W. Saunders and Messrs. Fauntleroy and Sons; the former is the most valuable ever yet formed. Besides these we have a small but very useful treatise by Mr. Charles Holtzapffel, with botanical notes by Dr. Royle; these are the only practical papers we can refer to upon a subject of such vast importance, and the limits of a single chapter will only admit of a small selection being made. Those selected are arranged according to country in five divisions, European, Asiatic, African, American, and Australian, and will comprise those only 
EUROPEAN WOODS.

which are imported from foreign countries, and of which the name of the producing tree is known.

\section{European Woods.}

Dantzic Dear, Spruce Fir, and Spruce.-The wood of Abies excelsa (Nat. Ord. Coniferce).

Dantzic Fir, Riga Fir, and Prussian Deal.-The wood of Pinus sylvestris.

These Coniferous plants furnish very much of the common timber used in the construction of houses, and the interior portions and decks of vessels; also in the inferior articles of household furniture. The imports are enormous, employing annually more than a hundred large vessels.

Norway Birch. Betula alba. (Nat. Ord. Betulacea.) -This is an inferior timber, used in common articles of furniture and in ship-building.

OAK.-Of this valuable timber several different species are imported, and used chiefly for ship-building. They are Baltic Oak, Quercus pedunculata (Nat. Ord. Corylacea) ; East Country Oak, Q. pedunculata ; Adriatic Oak, Q. Cerris; besides one or two doubtful ones.

Box-wood. Buxus Balearica. (Nat. Ord. Euphorbiacece.)-Large quantities of this wood, amounting to 3000 
or 4000 tons annually, are imported from Smyrna, Constantinople, and the Greek Islands; it is used in making blocks for wood-engravings, rollers for calico-printing, various toys, and articles of turnery. It is imported in pieces about four feet in length, and rarely exceeding ten inches in diameter, perfectly round, and of a yellowishwhite colour; it is a very hard close-grained wood, and is admirably adapted for the engraver and turner.

Orange. Citrus Aurantium (Nat. Ord. Aurantiacea).A yellowish-white wood, with fine close grain, used for inlaying and turnery.

WALnut. Juglans regia (Nat. Ord. Juglandacece).-A hard handsome wood, of a dark colour, beautifully feathered, the colours being a sort of umber and yellow. It is largely imported from Russia and Germany, and from North America, for making ornamental furniture.

Olive-wood. Olea Europaa (Nat. Ord. Oleacea).-A fine close-grained wood, usually yellowish, but often beautifully feathered; it is much used in small ornamental work for furniture.

\section{Asiatic Woods.}

Moulmein Teak, Ceylon Teak, Travancore Teak, and East Indian Teak, probably all from Tectona grandis 
(Nat. Ord. Verbenacea).-This timber, probably the most durable known, is very hard, and abounds in particles of silex, which of course renders it very heavy. This is an objection to its use in ship-building, for which purpose it would otherwise be the most valuable timber-tree known. It is nevertheless very extensively used for that purpose. Toon, Tunga, Poma, or Jeen-wood, the wood of Cedrela Toona (Nat. Ord. Cedrelacea), resembles mahogany, and is very much used for furniture, especially in the East Indies. It is not very often imported to this country.

Аmboyna Wood, Kyabuca or Krabooca Wood.-There are several varieties of this very beautiful wood found in our timber-yards; they are probably all furnished by the same tree, Pterospermum Indicum (Nat. Ord. Byttneriacea). It is most beautifully mottled and curled, of various tints from light-red to dark-yellow, and always in small lumps, being evidently excrescences or wens cut from the trees. The varieties of Amboyna wood are principally used for inlaying and by the makers of ornamental snuffboxes. Mr. Holtzapffel mentions the root of the Cocoa-nut Palm as being so much like Amboyna wood that it is scarcely distinguishable.

Ebony, Mauritius Ebony, the wood of Diospyros 
Ebenus (Nat. Ord. Ebenacea), (Plate XX. fig. 106,) is imported in square sticks three or four feet in length and seldom exceeding four inches in thickness; it is much used for inlaying and turnery. Its colour is black.

Black Евоny. Diospyros melanoxylon.-This wellknown black wood is very hard, heavy, and susceptible of a high polish. It is imported in sticks rarely more than four inches square and four feet in length. About 80 tons are imported annually.

East Indian Ebony, or Black-wood, Dalbergia latifolia (Nat. Ord. Leguminosce), is also a black heavy wood occasionally brought from the East Indies.

CaMphor Wood. Laurus Camphora (Nat. Ord. Lauracea).- This wood emits the camphor odour very strongly, and is imported occasionally from China for making cabinets for entomologists and others.

Iron Wood. Metrosideros vera (Nat. Ord. Myrtacea).This wood is immensely hard and heavy. It is imported from China in small quantities for various purposes.

SANDAL Wood, Santalum album (Nat. Ord. Santalacea), is remarkable for its agreeable fragrance, which is a preservative from insects; this wood is much used in making work-boxes and other trinkets, small cabinets, etc. 
Satin Wood (Indian). Swietenia chloroxylon (Nat. Ord. Cedrelacea). - This is a handsome hard yellow wood, occasionally imported for cabinet.makers.

Coromandel or Calamander Wood. Diospyros hirsuta (Nat. Ord. Ebenacea).- This is a very beautiful furniturewood, variegated with longitudinal brown and yellow, or yellowish-brown stripes, softening one into the other. There are two other varieties of it, called Kadum Bèriya (supposed to be from a different species, D. Ebenaster) and Omander. They all come from Ceylon.

Palmyra, Porcupine, and Spẹckled Woods-are the produce of one or more Palms, chiefly however from Cocos uncifera, the Cocoa-nut palm. The wood is called Porcupine or Palmyra when cut longitudinally, but fine prettily speckled veneers for inlaying are made by taking transverse sections ; the pieces of speckled wood are consequently very small. Brazil also furnishes these woods.

$\mathrm{J}_{\mathrm{AK}}$ Wood. Artocarpus integrifolia (Nat. Ord. Artocarpacea).-Jak or Jack-wood is from the Breadfruit-tree; it is of a yellowish colour, resembling orange-wood, and is imported to this country chiefly for making backs for hairbrushes and for inlaying in marqueterie floors, etc. 


\section{AFrican WoOds.}

The woods of Africa are very few in number, and only one is imported in considerable quantities : it is the

African OAK, or African TeaK. Oldfieldia Africana (Nat. Ord. Euphorbiacea).--Long as this valuable wood has been known, it was only in 1850 that its botanic characters were determined. In consequence of some seeds germinating at $\mathrm{Kew}$, it was at once ascertained by Mr. Bentham to be a new genus of Euphorbiacece, to which the name of Oldfieldia was given, in honour of the gentleman who sent the seeds. For some particular purposes in shipbuilding, this timber is unrivalled, but its great weight prevents its general application. The imports are considerable.

A species of Ebony is also frequently brought from the African Gold Coast in small pieces, or sticks, about two inches square and three or four feet in length, but nothing is known of the tree which produces it. It is chiefly used for inlaying, turning, and for the handles of surgical instruments.

\section{AMERICAN WoOds.}

THE WOODS OF NORTH AMERICA.

The greatest portion of the building timbers imported 
AMERICAN WOODS.

consist of the Coniferous and other woods from North America : thus the

White Pine or Deal of the United States of America, the produce of Pinus Strobus. The Yellow Pine or Deal, of Pinus palustris and P. mitis. The Red Pine or Deal, of Presinosa. The Pitch-Pine, Virginian Pine, and Georgian Pine, of Pinus rigida. The Hackmatack or Tamarack, of Larix Americana. The Virginian Red Cedar, of Juniperus Virginiana. The Red or Pencil Cedar, of Juniperus Bermudiana. The White Spruce, of Abies alba; and the Hemlock Spruce, of Abies Canadensis, - constitute the most common Deals, Pines, and Cedars used in carpentry; they all belong to the Natural Order Coniferce, and the trade in these timbers constitutes one of the most important branches of British commerce.

QUEBEC $\mathrm{O}_{A K}$ is produced by Quercus alba (Corylacea). This wood is also sometimes called White Oak; it is used in ship-building, etc.

Red Oak is from Quercus rubra; the Black Oak from Q. tinctoria; and the Live Oak from Q. virens.

The Walnut and Hickory woods belong to the Natural Order Juglandacea. We import the Black Walnut, produced by Juglans nigra; White Walnut, or Butter-nut 
wood, by $J$. cinerea; and Hickory, by Carya alba. These woods are chiefly used in making furniture, but Hickory is most valuable for hand-spikes.

Maple, Bird's-eye Maple, and Curly Maple are all varieties produced by Acer saccharinum, the Sugar Maple (Nat. Ord. Aceracece).

Locust-Wood.-The wood of Hymenca Courbaril (Nat. Ord. Leguminosa). It is hard, very tough, and is much used in making trenails for ship-carpenters; its colour is a light yellow. The quantity imported in the form of trenails is very considerable.

THE WOODS OF THE AMERICAN ISLANDS.

Bully-tree Wood, Black Bully. Achras Sapota. (Nat. Ord. Sapotacea.) - The Sapodilla-tree is a very lofty timber-tree, furnishing a valuable hard wood of a greenish colour; it is now often imported, and used chiefly in shipbuilding.

SABICU. -The wood of Acacia formosa (Nat. Ord. Leguminosa). This wood has acquired some interest from its having been used in constructing the stairs of the Crystal Palace in Hyde Park, where its durability was subjected to the severest test, and after six months' use the steps hardly 



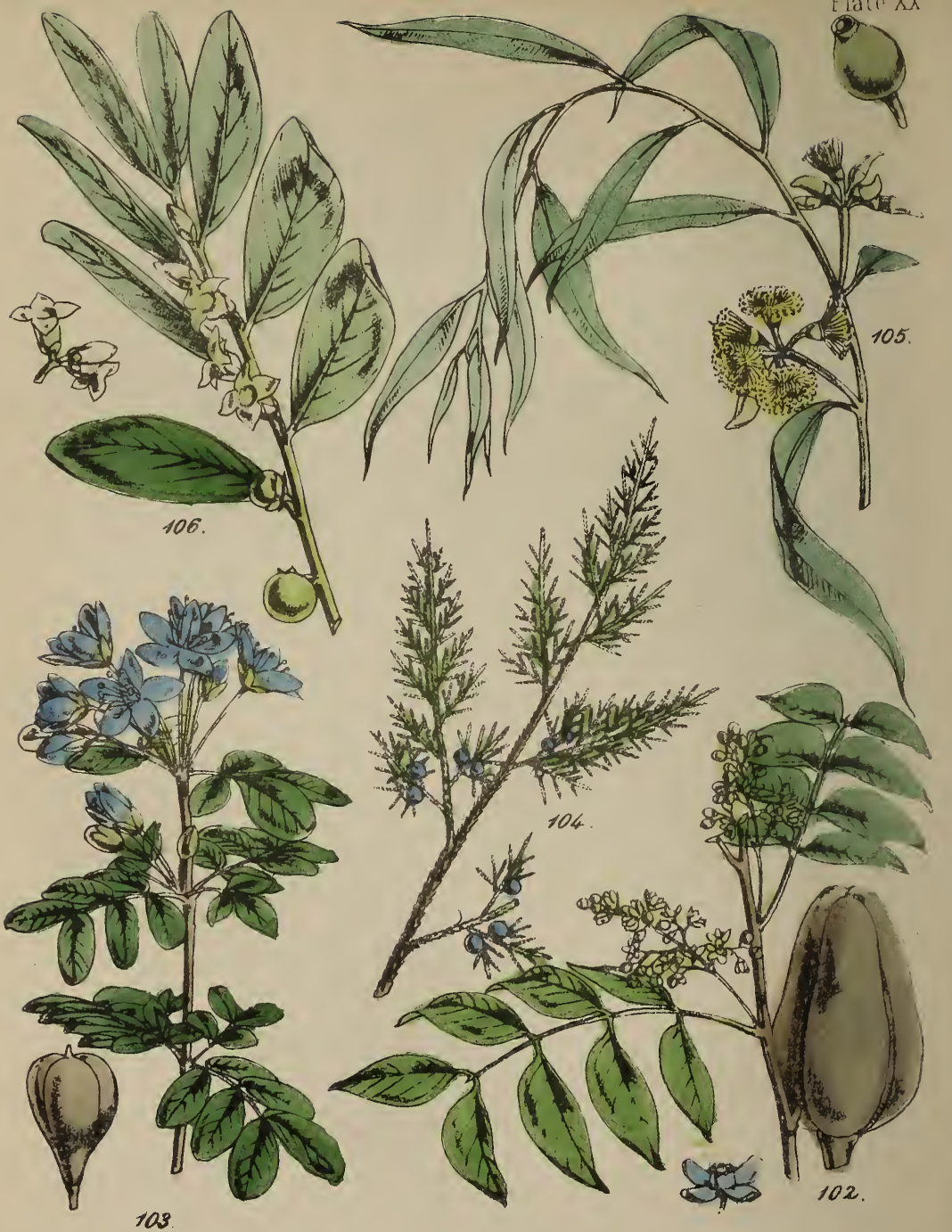

102 Wahogany Tree. 103. Lignum Tita. 104t'edar Tree 'pertil) 105. Gum Tree 106. Ebony Iree. 
exhibited any signs of wear. The Sabicu or Sabicue wood is extremely hard and tough; it has a dull red colour, and close short grain. It is imported from Cuba.

Cedar (Jamaica and Honduras). Cedrela odorata (Nat. Ord. Cedrelacea). (Plate XX. fig. 104.)-This cedar is imported in large logs often three or four feet square; it is soft and red, resembling the pencil cedar. Its use is for making the inside portions of furniture.

Mahogany. Swietenia Mahagoni (Nat. Ord. Cedrelacea). (Plate XX. fig. 102.)-This wood is too well known to need description; but few, who have it constantly before their eyes in some form of domestic furniture, reflect upon the difficulties and dangers of those who are engaged in supplying this favourite wood to the European markets. The mahogany grows in dense forests, where it forms one of the most lofty and gigantic of tropical trees. The mahogany-seeker has to mount to the top of some high tree of the forest, whence he surveys the sea of verdure around him, and easily detects the trees he looks for by their magnificent dimensions; he then, with a small pocket-compass, which is his most valued friend, takes the bearings of those which he sees, and having descended, proceeds from his place of observation in search of them, marking the various 
stems of trees which he passes, in order that he may safely retrace his steps. With immense labour and patience he fells the trees and lops and squares them, after which he has to cut roads through the forest to the nearest stream, to which the enormous logs of mahogany have to be drawn by timber-carriages and horses, and are there collected into large rafts; or each log is marked, and allowed to swim down the stream to some place where its progress is arrested by persons employed for that purpose. The quantity of mnahogany imported is immense, but the statistics of the timber-trade are so unsatisfactory that the author prefers omitting to give definite quantities, to the risk of propagating error. It is chiefly imported from Honduras and Cuba, but several of the West India Islands furnish mahogany.

Irgnum Vite. Guaiacum officinale (Nat. Ord. Zygophyllacea). (Plate XX. fig. 103.)-This very important wood comes chiefly from Jamaica; its chief use is in making blocks and pulleys for ships' rigging, and it is much used by turners for various articles requiring a hard closegrained wood; it also has some medicinal properties, and finds place in our pharmacopœia. It is imported in billets about three feet in length and a foot in diameter; the 
heart-wood is of a dark-brown colour, and intensely hard and heavy.

Lance Wood, Duguetia Quitarensis (Nat. Ord. Anonacea), is imported in poles fifteen to twenty feet in length, and six or seven inches in diameter, covered with a thin wrinkled bark. Lance-wood is much used for the shafts of gigs and other similar vehicles, and for a variety of purposes requiring great strength and elasticity. It is imported from Cuba and from Guiana.

Greenheart, Nectandra Rodicei (Nat. Ord. Lauracea), is a very fine, durable, hard wood, often imported from Demerara, and used as a substitute for Lignum-vitæ, which it slightly resembles; latterly it has been employed in pharmacy, in consequence of its yielding a chemical principle called Beeberine.

Satro Wood. Maba Guianensis (?) (Nat. Ord. Ebenacea.) - This beautiful wood, which has a light canary-yellow colour and satiny lustre, is imported chiefly from Nassau, in New Providence, one of the Bahama Islands. It comes in square logs about ten feet in length, and about eight inches square, and is used only for furniture and small fancy articles of cabinet-work.

Partridge Wood, Heisteria coccinea? (Nat. Ord. Olea- 
cea.)-It is much doubted whether this is the wood of Heisteria; some affirm it to be the produce of Andira inermis, a leguminous tree. It comes both from the West Indies and the Brazils, in tolerable-sized planks; it is of a reddish colour, beautifully streaked with parallel lines of a darker colour. Probably the woods of several trees bear the same name.

Cocus or KoKra Wood. Lepidostachys Roxburghii. (Nat. Ord. Scepacea.)-This wood is usually imported in short logs of about six or eight inches' diameter, having: bark and sap-wood of a light colour, while the heartwood is of a rich deep brown, and extremely hard; it is much used in the manufacture of flutes and similar musical instruments. It comes from $\mathrm{Cuba}$ and other West India Islands.

Zebra Wood, Guettarda speciosa (Nat. Ord. Cincluonacea), is brought in small planks from the West Indies; its colour is intermediate between those of mahogany and rose-wood; its variegations are less dark and more wavy than those of rose-wood. It is much valued for the finer kinds of furniture-wood.

Tortoise-wood is probably a variety of the same species. 


\section{'T'He Woods of South America.}

RosE-WOoD. - The wood of several undetermined species of Triptolomaa (Nat. Ord. Leguminose).- The varieties of Rose-wood are too well known to need description; they are exported from the Brazilian ports, in planks rarely exceeding twelve feet in length, flat on one side and round on the other; each being evidently one half of the stem, with the bark removed. The removal of the bark and splitting of the stem is probably for the purpose of ascertaining the quality of the wood before incurring the expense of transportation. Violet-wood and King-wood, two other beautiful Brazilian woods resembling the Rose-woods, are probably derived from other species of the same genus. They are in much smaler pieces, usually in round sticks about four or five feet in length, and varying in thickness from two to six inches; the colours are clearer than those of Rose-wood.

Snake Wood or Letren Wood, Piratinera Guianensis. (Nat. Ord. Artocarpacea.)-Probably the most beautiful of all fancy woods; it is of a rich chestnut-brown colour, beautifully mottled with large cloudy spots of deep umberbrown, strongly resembling the riarkings of some serpents. It is very scarce, and is only obtainable in small pieces; it is in sticks of two or three inches' diameter, rarely reaching 
five or six inches, and is merely the central heart-wood of a large tree.

Mora Wood, Mora excelsa (Nat. Ord. Leguminose), is the timber of one of the most majestic trees of Guiana, reaching the height of one hundred feet. Its colour is darker than mahogany, and its grain, close and tough, renders it very valuable for ship-building. The imports of this wood from British Guiana are increasing considerably.

Purple Wood, or Purple Heart. Copaiba pubiflora. (Nat. Ord. Leguminose.)-Another of the woods of Guiana, which is extensively used for making the sticks of musket ramrods. Its colour is peculiar, being a sort of puce; it is imported only in small pieces.

\section{Australian and New Zealand Woods.}

Huon Pine. Dacrydium Franklinii (Nat. Ord. Taxacece).-This timber of a large tree belonging to the Yew tribe is valuable for ship-building, for which purpose it is occasionally imported.

Blue Gum Wood. Eucalyptus piperita. (Nat. Ord. Myriacece.) (Plate XX. fig. 105.) - One of the most lofty trees in the world, often rising two hundred feet in height, with fine column-like stems rising one hundred to one 
hundred and fifty feet without a branch. The wood is very hard and difficult to work. A single plank was imported into Liverpool, intended, but too late, for the Great Exhibition; it measured one hundred feet in length, two feet six inches broad, and three inches in thickness, and sold for more than $£ 100$. Tt is used chiefly for ship-building purposes.

Red Gum Wood. Encalyptus resinifera.-Wood very similar to the last, but rarely in such large logs.

Botany Bay OaK, Beef-wood, He-OaK, She-OaK, and Forest OAK, names applied to different species of Casuarina (Nat. Ord. Casuarinacea).-The species of which the timber is imported are C. torulosa, the Forest-oak; C. paludosa, the Swamp-oak ; C. equisetifolia, the He-oak; and $C$. stricta, the She-oak and Beef-wood. This peculiar group of trees, called Botany Bay Oaks, all yield wood of a similar character, and receive the above names indiscriminately. It is ornamental, and well adapted for inlaying and marqueterie; its colour is a light yellowish-brown, marked often with short veins of a redder colour.

New Zealand Pine, or Cowdie Pine, Damara Australis, (Nat. Ord. Coniferce.)-This timber is much valued for masts and spars, for which purpose much is imported for 
use in our navy-yards. It yields the largest and strongest spars of any known tree.

'THere is no branch of Economic Botany requiring the investigation of men of science more than the history of Timber-trees; it is lamentable to see talented botanists labouring over the definition of some species or variety, possessing no other interest than the technical difficulties of its characters, whilst we are totally ignorant of even the names of the plants producing two-thirds of our most valuable timber and furniture woods. This circumstance also offers an argument to those mon-scientific persons who cavil at the technicology of science, and would have common vernacular names applied to all things; for amongst the woods of commerce this practice has prevailed, and has produced such a mass of errors, that it appears almost hopeless to expect to unravel them. For instance, we have a dozen different varieties called Iron-wood; half-a-dozen Beefwoods; four or five Satin-woods; and a host of others, named according to the fancy of the wood-cutters, shippers, 
or importers; until it has become difficult for a dealer to know which sort of Iron-wood, Beef-wood, Satin-wood, etc., his customer wants. The scientific botanist would have chosen less familiar, but certainly more definite, terms.

This brings us to the conclusion of an attempt to describe the most important products of the Vegetable Kingdom which constitute the foreign commerce of our country. To many the number of articles will be a matter of surprise; but, numerous as the products are which the energy of man has discovered for his use and profit, they are few compared with those which a bountiful Providence has still in store for us. Not a year passes but adds to our riches in this respect; and when public attention and the investigations of scientific men are more fully directed to this branch of learning, an immense harvest will be reaped from the now unknown treasures of the vegetable kingdom. Many may say, Have we not all we require? The answer to this is, We might have said the same before Dr. Montgomery discovered that the Malays made the handles of their hatchets of the hardened juice of a tree, and yet what inestimable benefits has that discovery conferred! How would the difficulties of the Submarine Telegraph have been overcome without Gutta Percha? In order to 
direct attention more fully to the vast importance of this study, Museums of Raw Produce should be formed on a large scale, showing not merely the products themselves, but all their known applications. At present we have only two rudimentary establishments of this kind, both too small to be of any great service, though useful in their way : they are the Botanical Museum at Kew, and the Collection of Imports at Liverpool, made by the author for the Great Exhibition, and now in the Free Public Museum of Liverpool. 


\section{N D EX.}

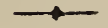

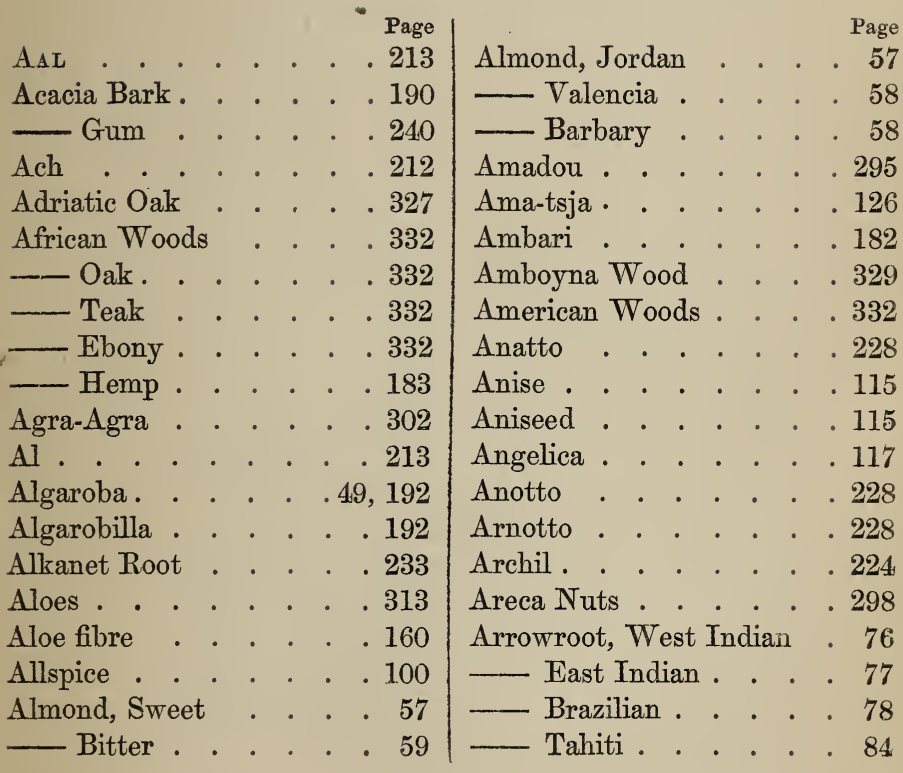


Asphalte $\quad \begin{array}{r}\text { Page } \\ 25\end{array}$ Attar of Roses . . . . . 277 Australian Woods. . . . 340 Copal . . . 247 Avignon Berries . . . . 219

Babool Bark. . . . . 190 Gum . . . . . 242

Balsam, Canada . . . . 351 Baltic Oak . . . . . . 327 Bamia . . . . . . 142 Banana . . . . . 45 Bandikai . . . . . . 142 Bang . . . . . . . 155 Barba Hispanica . . . . 161 Barcelona Nut . . . . . 61 Bark, Acacia . . . . 190 Babool . . . . . 190 Cassia . . . . . 92 Canella . . . . 110 Clove . . . . . . 93 Culilawan . . . 93 Cork-tree. . . . 188 Mangrove . . . 189 _- Oak . . . . . 187 — Pomegranate . . . 190 Barley . . . . . . 7 Long-eared .
Barley, Common

Page Spring. Winter Sprat Battledore Bar Wood Bast Beans, American Egyptian. French

— Haricot (American) (French)

Beeberine Beef-wood Beet Sugar Ben Nut . Bere

Bigg . Birch

Bird's-eye Maple Black Bully Wood

. 206 . 166 . 17 17 18 18 18 . 337 . 341 . 139 .271

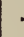
Ebony.

- Walnut Wood .

\section{Blue Gum Wood .}

Boehmeria Flax

Botany Bay Oak

Bowstring Hemp - 7 7 327 . 334 . 334 330 333 . 340 . 183 341 Box Wood . . 
INDEX.

Brazil Nut Page

Brazil Wood . . . . 204

Braziletto Wood . . . 206

Brazilian Tea • • • . 126

Brésil de St. Martha . . 203

Brown Catechu . . . 198

Buck-wheat . . . . 16

Building Woods . . . . 325

Bully-tree Wood . . . . 334

Bully Wood, Black . . . 334

Bulrush . . . . . 168

Butter Nut . . . . . . 64

Butter Nut Wood . . 333

Cacao . . . . . . 134

Calamander Wood . . . 331

Calamus Root . . . . 300

Caloee Hemp . . . . 183

Camphor . . . . . . 314

Wood . . . . . 330

Cam-wood . . . . . 205

Camata . . . . . 189

Camatina . . . . . 189

Canada Balsam. . . . . 251

Canes, Malacca. . . . . 304

Partridge . . . . 305

Penang Lawyer . . 305

Bamboo . . . . 306
Page

Canes, Jambees . . . 306 Rattan . . . . . 167 Reed . . . . . 306 Canella Bark . . . . 110 Caoutchouc . . . . . 253 Caper . . . . . . . 141 Capsicum. . . . . . 106 Caraway Seed . . . . 112 Cardamoms . . . 107, 322 Malabar . . . . 107 Ceylon. . . . . . 108 Java . . . . . 108 Round . . . . . . 108 Cluster. . . . . 108

Carob . . . . . . . . 49 Carrageen . . . . . . 303 Cascarilla Bark. . . . . 322 Cassava . . . . . . 79 Cassaripe . . . . . . 78 Cassia . . . . . . 92 Lignea . . . . . 92 Buds . . . . . . 92 Fistula. . . . . 318 Castor Oil . . . . . . 321 Castanha Nut . . . . . 51 Catechu . . . . . . 193 Pegu . . . . . . 198 Brown . . . . 198 
Ceci . . . . . . . 19

Cedar, Red . . . . . . 333 Pencil . . . . . . 333

— Virginian Red Jamaica Honduras .

Ceylon Teak. Chay-root

Che-root . . . . . . 212

Chestnut . . . . . 64 - American . . . . . 65

Chicory . . . . . 132

Chocolate. . . . . 134

Churrus . . . . . 153

China Grass . . . . . . 163

Chick-pea . . . . . . 19

Cicer . . . . . . . 19

Cinnamon . . . . 88

Citron . . . . . . . . 41

Clover, Dutch . . . . 20

American . . . . 20

Clove Bark . . . . . . 93

Cloves . . . . . . . . 98

Cob-nut . . . . . . 61

Cocoa, or Cocao $\quad$. . . . 134

Cocoa, or Coker Nut . . . 67

Cocoa Nut fibre . . . . 161

Cocus Wood . . . . . 338
Page

Coffee . . . . . . . 129

Coir . . . . . . . 161

Colophony . . . . 250

Constructive Materials . . 325

Coquilla Nut . . 166, 297

Coriander. . . . . . . 113

Cork . . . . . . . 294

Cork-wood . . . . . 294

Cork-tree Bark . . . . . 188

Coromandel Wood . . . 331

Cotton Wool . . . . 170

. 269

Cowdie Pine . . . . . 341

Cranberry . . . . . . 48

Curly Maple . . . . . 334

Currants . . . . . 26

Cutch . . . . . . . 193

Dammar . . . . . . 247

Dantzic Deal . . . . 327 Fir . 327

Darra . . . . . . . 14

Dates . . . . . . 30

White . . . 30 Tafilat. .. . . . 30

Date Sugar . . . . . 140

Deal, Dantzic . . . . . 327

Prussian . . . . 327 
Page

Deal, White . . . . 333 Yellow . . . . 333 Red . . . . . . 333

Dextrine . . . . . . 75

Divi-Divi. . . . . . . 191

Dragon's Blood, . . . 233

Duchai Hemp . . . . . 183

Durra. . . . . . . 14

East Country Oak . . . 327 East Indian Arrowroot . . 77 Ebony . . . 328 Teak . . . 320

Ebony . . . . . . . 329

Mauritius. . . . . 329 Black . . . . . 330 East Indian . . . . 330 African . . . . 332 Green . . . . . . 208

Egyptian Beans . . . . 17

Lentils . . . . . 19

Ejow fibre . . . . . 164

Embden Groats . . . . 6

Ergot of Rye . . . . 8

Essential Oils . . . . . 272

Essence of Lemons . . . 272

of Bergamot . . . 273 de Petit Grain . . 273
Essence of Neroli

Page

European Woods .

273

327

Farinaceous Products . . 1 Feculas . . . . . 71 Fig . . . . . . . 26 Fig-cake . . . . . . 28 Fir, Spruce . . . . . . 327 Dantzic . . . . 327 — Riga . . . . . 327 Flax . . . . . . 148 Cotton. . . . . . 148 New Zealand . . . 164 Flavine . . . . . . 215 Forest Oak . . . . . . 341 Forbidden Fruit . . . . 38 Folia Malabathri . . . 90 French Bean . . . . . 18 Plum . . . . . . 29 Frankincense . . . . 250 Fruits. . . . . . . 23 Furniture Woods . . . . 325 Fustic. . . . . . . 207 old . . . . . . 207 young . . . . . . 218

Galls . . . . . . 326 Gall-nuts . . . . . 326 
Page

Gamboge. . . . . . 235

Garancine . . . . . 211

Gawatha . . . . . 160

Garlic. . . . . . . 144

Georgian Pine . . . . 333

German Tinder . . . . 295

Ginger : . . . . .104

Jamaica White. . . 105

Black . . 106

Barbadoes . . . . 105

African . . . . . 105

East Indian . . . . 105

— Tellicherry . . . 105

- Malabar . . . . 106

Gobbio . . . . . 142

Gobbe. . . . . . 67

Gombo . . . . . . 142

Gommuti . . . . .164

Gram . . . . . . 19

Grape. . . . . . . 23

Grains d'Avignon . . . . 219

Grains of Paradise . . 108

Groats . . . . . 6

Greenheart . . . . . 337

Ground Nut . . . . 65

Green Ebony . . . . 208

Guinea Corn . . . . 14
Gunjah . . . . . . 154

Guava. . . . . . . 43

Guayaba . . . . . . 43

Gutta Percha . . . . 255

Gums used in the Arts . . 239

Gum Arabic. . . . . 240

Acacia . . . . . . 241

Asafotida . . . 308

Ammoniacum . . 310

Babool. . . . . 190

Barbary . . . . . 241

Bassora . . . . 245

Benzoin . . . . 301

Benjamin . . . . 301

Copal . . . . . 246

Brazilian . . 246

African . . 246

Australian . . 247

East Indian . . 247

Dammar . . . . 247

Dragon . . . . . 243

East Indian . . . . 242

Elemi . . . . . . 311

Elastic. . . . . . 253

Gedda . . . . . 241

Gattie . . . . . 242

Galbanum . . . 309

Juniper . . . . . 249 
INDEX.

Gum Kawrie . . . . . 247

Hickory Nut

60

Kuteera . . . .245

Wood .

334

Mastic . . . . . 248

Hog-nut . . . . . . 64

Myrrh . . . . . .311

Oomrawattee . . . 242

Hominy . . . . . . 10

Hop . . . . . . 144

Opoponax. . . . 310

Huon Pine . . . . . . 341

Sagapenum . . . 309

Sandarach . . . . 249

India Rubber . . . . . 253

Scammony . . . 310

Senegal . . . . 241

Storax . . . . . 302

Styrax . . . . . 302

Tragacanth . . . . 243

Hackmatack . . . . . 333

Indian Corn . . . . . 9

Indian Grass Matting . 181

Indigo. . . . . . . . 292

Iris Root. . . . . . . 300

Irish Moss . . . . . . 303

Iron-wood . . . . . . 330

Hazel Nut . . . . . 60

Hemp. . . . . . . . 151

Bengal . . . . . 158

Jute . . . . . 157

Italian Rye-grass Seed . . 21

Manilla . . . . 158

Sun. . . . . . 158

Brown Indian . . . 182

African . . . . 183

Jak Wood . . . . . 331

Jalap . . . . . . . 316

- He or Male . . . 317

Jamaica Pepper . . . . 100

Jeea Wood . . . . . . 329

Jerusalem Filbert. . . . 60

Jetee . . . . . . . 182

Joar . . . . . . . 14

Johannisbrod . . . . 49

Juniper Berries . . . . 298

He-Jalap. . . . . . . 317

Jute . . . . . . 156

He-Oak . . . . . 341 Juvia . . . . . 51 
Page

Kadi-kane . . . . . . 15

Kadum Berija Wood. . . 338

Kala-kangnee . . . . 15

Kassu . . . . . . . . 198

Kawrie Gum . . . . . 247

Kayo Umur Panjang. . 126

Kenguel . . . . . . 133

King Wood . . . . . . 339

Kiabooca Wood . . . . 329

Kokra Wood . . . . . 338

Kora-Kang . . . . . . 15

Koongoonie . . . . . 15

Kyabuca Wood . . . . 329

Kyar . . . . . . 161

Labrador Tea . . . . 127

Lac Dye . . . . . . . 232

Lance Wood . . . . . 339

Lemon . . . . . . 39

- Gaeta . . . . . 39

—- Imperial . . . . . 39

— Wax . . . . . . 39

Lentils . . . . . . 19

Letter-wood . . . . . 339

Libi-dibi . . . . . 191

Libi-divi . . . . . . 191

Lignum Vitæ . . . . . 336

Lima-wood . . . . . 203
Lime . . . . . . . . 40

Liquorice . . . . . 313

Litchi . . . . . . . . 44

Locust . . . . . . . 49

Wood . . . . . 334

Logwood . . . . . . . 201

Lupins . . . . . . 19

Mace . . . . . . . . 97

Madder Root . . . . 209

— East Indian . . . 211

Maize . . . . . . . 9

Starch .. . . . 83

Mandiocca . . . . . . 79

Mangkudu . . . . . . 212

Mango . . . . . . . 43

Mangrove Bark . . . . 189

Manilla Hemp . . . . 158

Manna . . . . . . . 312

Manna Croup . . . . 86

Male Jalap . . . . . . 31

Mahogany . . . . . . 335

Maple, Bird's-eye . . . . 334

Curly . . . . . 334 Sugar . . . . . 140

Malacca Canes . . . . 304

Malaguetta Pepper . . . 108

Marking Nut . . . . . 56 
INDEX.

353

Mastic . . . . . . . 248

Page

Page

Maté . . . . . . . 125

Materia Medica . . . 307

Mauritius Ebony . . . . 329

Medicinal Products . . 307

Melasses . . . . . . 139

Mexican Tea . . . . . 127

Millet.

15

Turkish . . . . . 14

Italian . . . . . 15

German . . . . . 15

Miserable . . . . . . 135

Molasses . . . . . . 139

Monkey Grass . . . 164

Momeea . . . . . . 153

Mora Wood . . . . . 340

Morghaee . . . . . . 183

Morell . . . . . . . 146

Mountain Tea . . . . 126

Moulmein Teak . . . . 328

Mummy Wheat . . . . 4

Munduli . . . . . 66

Munjeet . . . . . . 211

Munjeeth . . . . . . 211

Mustard . . . . . . 111

Myrobalans . . . . . 198

Myrabolams . . . . . 198

Neb-neb . . . . . 192

New Zealand Flax . . . 164

Woods . . 340

Pine . . . 341

Negro Corn . . . . . 14

Neilgherry Nettle . . . 183

Nib-nib . . . . . . . 193

Nicaragua Wood . . 203

Norway Birch . . . . 327

Nutgalls . . . . . . 228

Nutmegs . . . . . . 95

Long . . . . . 96

Shell . . . . . . 96

Wild . . . . . . 96

False . . . . . . 97

Ackwai . . . . . 97

Brazilian . . . . . 97

Clove . . . . . 97

Nux Vomica . . . . . 314

Oak . . . . . . 327

Botany Bay . . . 341

Forest . . . . . 341

$\mathrm{He}$. . . . . . 341

Quebec . . . . 333

Red . . . . . . 333

She . . . . . . 341

Baltic . . . . . 327

Adriatic . . . . . 327

East Country . . . 327 
Oak, African . . . . $\begin{array}{r}\text { Page } \\ 332\end{array}$ Galls . . . . . 226 Bark . . . . . 187

Oat . . . . . . 5

White . . . . 6

Black . . . . . 6

Tartarian . . . 6

Potato . . . . 6

Oils and Oil Seeds . . 259

Oils, Essential . . . . . 272

Oils :-

Almond . . . . . 265

Aniseed . . . . .276

Bergamot .. . . . 273

Caraway . . . . . 277

Cassia . . . . .276

Cetronelle . . 274, 279

Cloves . . . . . 276

Cocoa Nut . . . . 263

Cinnamon . . . . 276

Indian Grass . . . 279

Juniper . . . . . 274

Koosum . . . . . 268

Lavender . . . . . 275

Lemons . . . . . 272

Lemon Grass . . . 279

Mint . . . . . . 276

Molucca Lemon Grass 280
Oils, continued :-

Page

Neroli . . . . . 276

Nutmegs . . . . . 276

Olive . . . . . 264

Orange . . . . . 273

Orange-leaf . . . .- 273

Orange-flower . . . . 273

Origanum . . . . . 275

Peppermint . . . . 276

Pimento . . . . . 276

Palm . . . . . . 261

Roosa . . . . . . 279

Roses . . . . . . . 277

Rosemary . . . . 275

Rape . . . . . . 265

Thyme . . . . . . 275

Turpentine . . . . 272

Seed . . . . . . 265

Okra . . . . . . . . 142

Okro . . . . . . . 142

Old Fustic . . . . . . 207

Olive . . . . . . . 34

Wood . . . . . 328

Omander Wood . . . . 331

Onion . . . . . . 143

One-grained Wheat . . 4

Opium . . . . . . 323

Orange, Sweet . . . 36 
INDEX.

Orange, Bitter ‥ . . 37 Seville . . . . 37 Navel . . . . . 38 Brazilian . . . 38 Tangerine . . . 38 Wood

Orchella Weed

Orchil

Orrice Root

Oswego Tea

Otaheite Salep

Otto of Roses

Patchouli

Paddy

Palm Cabbage

Palmyra Wood

Fibre

Palungeo

Para Nut

Grass

Paraguay Tea

Parkinsonia Fibre

Partridge Wood

Peas

Peach Wood

Pegu Catechu . . . . . 198

Pepper, Black
. 328

220

. 224

300

.127

84

277

299

13

32

331

. 182

182

51

. 165

. 124

182

338

17

203

102
Pepper, White

Page

Long

Cayenne

Malagueta

Persian Berries

103

Peruvian Bark

Pi-pi

Piaçaba

Piassava

Pine Apple

Fibre

Pichurim Beans

Pine, White

Yellow

Red

Pitch

Virginian

New Zealand

Georgian

Huon

Cowdee

103

. 106

. 108

. 219

. 318

. 192

165

. 165

47

. 160

94

333

333

333

333

333

341

. 341

341

340

Pistachio Nut . . . . 67

Pita . . . . . . 160

Pite Hemp . . . . . 160

Pitch . . . . . . 252

Polish Wheat . . . . 4

Pomegranate . . . . 33

Bark . . . . . 190 
Page

Poona Wood . . . . . 329

Porcupine Wood . . . . 331

Pot Plant . . . . . . 53

Prickly Pear . . . . . 44

Prunes . . . . . . . 29

Pucha-pat . . . . . . 299

Purple Wood . . . . . 340

Quebec Oak . . . . 333

Quercitron Bark . . . 215

Raisins . . . . . 24 Sultana . . . . . 25

Black . . . . . 25

Muscatel . . . . . 25

Valencia . . . . . 25

Lexia . . . . . 25

Denia . . . . . 25

__ Malaga . . . . . 25

— Red Smyrna . . . 25

Rattan Canes . . . . . 167

Red Cedar . . . . . . 333

Oak . . . . . 333

Gum Wood . . . 341

Red Smyrna Nut . . . . 60

$$
\text { Raisin . . } 25
$$

Revalenta Arabica . . . 19

Rhea fibre . . . . . 183
Page

Rice . . . . . . . 11

- starch . . . . . 83

295

Riga Fir . . . . . . . 327

Rock Moss . . . . . . 225

Roosa-ke-til . . . . . 278

Roosa Oil . . . . . . 278

Rose Wood . . . . . . 339

Rosin . . . . . . . . 250

Rushes, Bull- . . . . . 168

Dutch . . . . . 304

Rye . . . . . 8

Sandal Wood . . . . 330 Red . . . . . 206

Satin Wood . . 331-337

Sabicue Wood . . . . 334

Safflower . . . . . . 216

Saffron . . . . . . 217

Sago . . . . . . 81

flour . . . . . 82

- meal . . . . . 82

Salep . . . . . . 85

Saloop . . . . . . 85

Sapan Wood . . . . 205

Root . . . 205

Sapucaia Nut . . . . . 53

Sassafras Nuts . . . . 94 
INDEX.

Page

Saunders Wood . . . 206 Semolina . . . . . 86 Semoletta . . . . 86 Semola . . . . . . 86 Semola rarita . . . . . 86 Seeds :-

Flax . . . . . 267 Teel . . . . . 267 Til . . . . . 267 Gingelly . . . . 267 Gingellie . . . . . 267 Sesamum . . . . . 267 Bennie . . . . . 267 Niger . . . . . . 268 Carthamus . . . . 268 Mustard . . . . . . 269 Cotton . . . . . . . 269 Poppy . . . . . . 269 Senna leares . . . . . . 317 She-oak . . . . . . 341 Shunum . . . . 158 Shumac . . . . . 220 Shaddock . . . . . 38 Silk, Vegetable . . . . 181 Sidhee . . . . . . . 155 Snake Wood . . . . . 339 Souari Nut . . . . . . 54 Soy
Soy Bean

Page Soojee . . . . . . . 86 Spirits of Turpentine . . 250 Spruce . . . . . . 327 White . . . . . 333 Hemlock . . . . 333 Fir . . . . . . 327 Speckled Wood . . . . 331 Spelt Wheat . . . . 4 Spanish Moss . . . . . 161 Nuts . . . . . 61 Spices . . . . . . . 87 Starches . . . . . . 71 St. John's Bread . . . . 49 Sumach . . . . . . 220 Sun . . . . . . . 158 Sunnee . . . . . . 182 Surahwa Nut . . . . . 54 Suwarrow Nut . . . . 54 Sugar . . . . . . . 135 Beet . . . . . 139 Date . . . . . . 140 - Maple . . . . . 140 Subjee . . . . . . . 155 Sweet Wood Bark . . . 322

Taag . . . . . . . 158 Tafilat Date . . . . 30 
Page

Tamarack Wood . . . . 333

Tamarind . . . . . 42

Tapioca . . . . . 79

Tar . . . . . . . 251

Tares . . . . . . 18

Tartarean Oat . . . . 6

Tea . . . . . . 118

Black . . . . . . 118

Green . . . . . . 118

Assam . . . . . . . 118

Paraguay . . . 124-127

Apalachian . . . . . 125

New Jersey . . . . 125

of Hearen . . . . . 126

Labrador . . . . 126

Brazilian . . . . 126

Mountain . . . . 126

Mexican . . . . . 127

Oswego . . . . . 127

Toolsie . . . . . 127

Teak, Moulmein . . . . 328

African . . . . . 332

Travancore . . . . 328 East Indian . . . . 328

— Ceylon . . . . . 328

Teazles . . . . . . 303

Terra Japonica . . . . 193

Thus . . . . . . 250
Page

Timothy Grass Seed . . . 21 Tobacco . . . . . . 284 Tonca Bean . . . . . . 298 Tonga Bean . . . . . 298 Tonquin Bean . . . . 298 Toolsie Tea . . . . . . 127 Toon Wood. . . . . . 329 Tortoise Wood . . . . 338 Tous les Mois . . . . . 86 Treacle . . . . . . . 139 Tree of Long Life . . . 126 Truffles . . . . . . 145 Turkish Millet . . . . . 14 Turmeric. . . . . 203 China . . . . 204 Bengal . . . . .204 Madras . . . . 204 Malabar . . . . 204 Java . . . . . .204

Tunga Wood . . . . . 329 Turpentine . . . . . 249

Urena . . . . . . 86

Valonia . . . . . . 189 Vanile . . . . . . 109 Vanilla . . . . . . . 109 Vegetable Silk . . . 181-183 
INDEX.

359

Page Wheat, Summer . . $\quad \begin{array}{r}\text { Page } \\ 2\end{array}$

Vegetable Tallow . . . . 280 Indian . 280 Chinese . 280

Vegetable Wax, Chinese . 281 S. American . 281 Myrtle . . 281

Vegetable Irory . . . . 296 Vetches . . . . . . 18 Violet Wood . . . . . 339 Virginian Red Cedar . . 333 Pine . . . . . . 333

Walnut . . . . . 62 Black . . . . . 328 White. . . . . 333 Wood . . . . . 328 Warree . . . . . . 15 Water Melon . . . . . 48 Wheat, Winter . . . 2 Mummy . . . 3 Polish . . . . . . 4 Spelt . . . . . . 4 One-grained . . . 4 White Spruce . . . . 333 Oat . . . . 6 - Lupins . . . . . 19 - Date . . . . . 30 Wild Locust . . . . 49 Wool, Cotton . . . 170

Yellow Pine . . . . 333 Deal . . . . . 333 Berries . . . . . 219 Wood . . . . . 205 Yerba . . . . . . 129 Yercum fibre . . . . . 182 2 Young Fustic . . . . . 208 


\section{PRINTED BY \\ JOHN EDWARD TAYLOR, LITTLE QUEEX STREET, LINCOLN'S INN FIELDS.}




PB59097

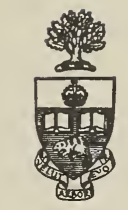

Library

of the

University of Toronto 

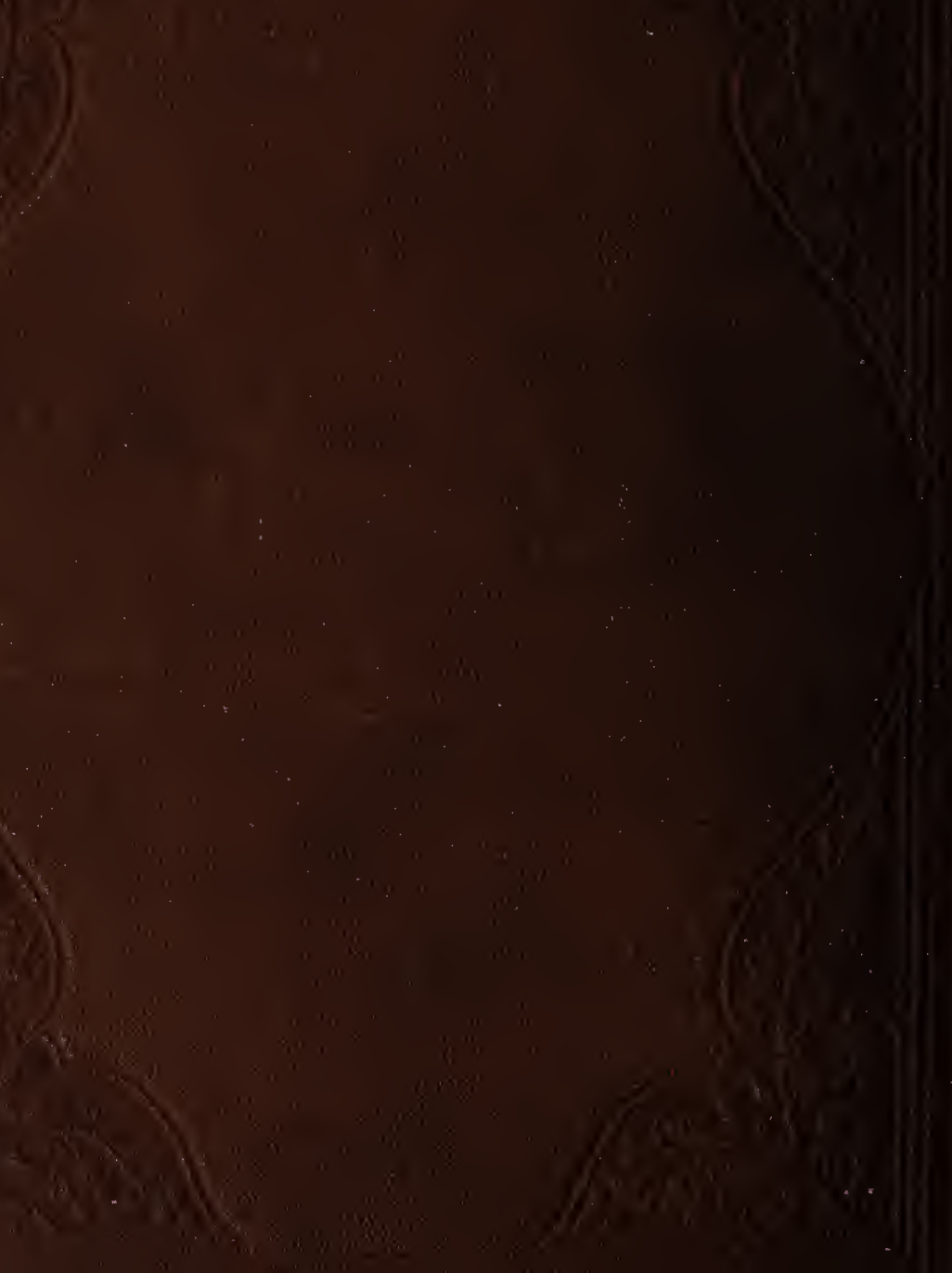